\author{
A N

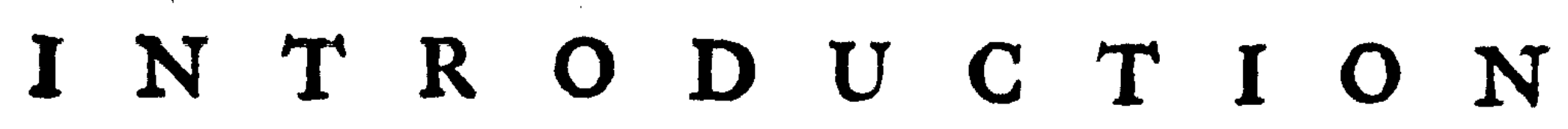 \\ TO THE \\ $\begin{array}{llllllllll}\mathbf{P} & \mathbf{R} & \mathbf{I} & \mathbf{N} & \mathbf{C} & \mathbf{I} & \mathbf{P} & \mathbf{L} & \mathbf{E} & \mathbf{S}\end{array}$ \\ $O B$
}

\title{
MORALS AND LEGISLATION.
}

PRINTED IN THE YEAR I 780 ,

AND NOW FIRST PUBLISHED.

$B$ Y

JEREM Y BENTHAM, OP IINCOLN'S INN, ESQUIRE.

L. O N D O N:

Pa:ited ror T. PAYNE, AND SON, at THE MEWS Gath.

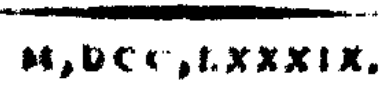




\section{N T R O D U C T I O N}

T O T H E

\section{Principles of Morals and Legillation.}

\section{$\begin{array}{llllll}\mathbf{E} & \mathbf{R} & \mathbf{R} & \mathbf{A} & \mathbf{T} & \mathbf{A} \text {. }\end{array}$}

PAGE 16, note, line 5, after actions, dele of thofe individuals. INTROD.

P. 17, note, 1.6 from tbe bottom, for counterbaft, read counterblaft. Cosesc-

$P$. 37, note $f$, in tbe marginal note, for a good name, read an ill name. Troxs.

Ib. for an ill name, read a good name.

$P .65$, note, 1. laft, for privilegiaturum, read privilegiatarum.

$P .73,1.4$, after indivifible, dele tbe comma.

P. 84, l. 3, for leg was, read hand was.

P. 106, 1.6 from tbe bottom, for peremptory, read peremptorily.

$P .173, l .12$, for members, read the members.

$P .206$, note, $l .6$, dele is in a way that.

$P .213$, note, 6.7 from tbe bottom, for inconvenience, read inconveniences.

P. 286, 1. 23, for exhauftic, read exhauftive.

P. 293. l. 23, for monolopy, read monopoly. 


\section{CORRECTIONS AND ADDITIONS. \\ Re-printed January 1789, from a Sheet printed ORIGINally AbOUT THE Year 1783.}

N. B. The above Sheets having been printed off in November 1780 , the following Corrections and Additions have occurred in the mean Time.

INTROD.

$P A G E 13,6.2$ from the bottom, par. XIV. after as a realon, infert and TiOns.

$P .26, l .5$, for in other words, put in another point of view.

$P .31, l .5$, after 2. infert the pleafure of intoxication, and alter tbe otber numbers accordingly.

16. By soay of note to the end of paragrapb IV. infert as follows: There are alfo pleafures of novelty, excited by the appearance of new ideas: thefe are pleafures of the imagination. See infra XIII.

P. 34. By way of note to the end of paragrapb XIV. infert as folloros: In contradiftinction to thefe, all other pleafures may be termed pleafures of enjoyment.

P. 38. By way of note to the end of paragrapb XXX. infers as follows : In contradiftinction to thefe, all other pains may be termed pains of sufferance.

P. 73. Between par. XIX. and XX. infert tbe following: Fifthly, acts may be diftinguifhed into fimple and complex: fimple, fuch as the act of ftriking, the act of leaning, or the act of drinking, above inftanced : complex, confifting each of a multitude of fimple acts, which, though numerous and heterogeneous, derive 2 fort of unity from the relation they bear to fome common defign or end; fuch as the act of giving a dinner, the act of maintaining a child, the act of exhibiting a triumph, the act of bearing arms, the act of holding a court, and fo forth.

P. 127. In the reference at the bottom of tbe page, for See Append. tit. [Preventive Inttitutions] read See Eflay on indireat legillation.

$P .202$, note, 1.15 , for their congruencies, read their real congruencies.

Ib. $l$. I 5 , for their names, read their current names.

16. 1. 16, for a conformable fet of names, read other more appolite denominations.

P. 206. 
P. 206. 1.5, for he bears to the before-mentioned exterior objects, read which the before-mentioned exterior objects may happen to bear, in the way of caufality (See Ch. 7. Actions, par. 24) to his happiners.

P. 208, $1.6, \&$ 7, for 2. Offences againft property. 3. Offences againft reputation, read 2. Offences againft reputation. 3. Offences againft property.

P. 235, l. 21, after detrectation, infert or non-affumption.

$P .245, l$. 10, after Vilification, infert or Revilement.

$P .247$, note, 1.5 from tbe bottem, dele the reference.

Ib. $\quad$ l. 3 from the bottom, for would cover, read would be enough to cover.

Ib. note $n$, add, There are fome fervices, we may obferve, the withholding of which may affect the perfon, and by that means come under the negative branches of the feveral genera of corporal injuries; fuch as fervices due from a furgeon, an innkeeper, \&zc.

P. 248, l. 16, after detainment, infert or detention.

P. 250. Since tbe printing-off of that ßbeet, I bave difcovered feveral omiffions in the satalogue of offences againft property; wbich catalogue, were tbofe amifions to be supplied, roould ftand tbus: 1. Wrongful non-inveftment of property. 2. Wrongful interception of property. 3. Wrongful diveftment of property. 4. Ufurpation of property. 5. Wrongful inveftment of property. 6. Wrongful with-holding of fervices. 7. Infolvency. 8. Wrongful interception of fervices. 9. Wrongful obtainment of fervices. 10. Wrongful impofition of fervices. II. Wrongful impofition of expence. 12. Wrongful deftruction or endamagement. 13. Wrongful occupation. 14. Wrongful detention. 15. Wrongful difurbance of proprietary rights. 16. Theft. 17. Embezzlement. 18. Defraudment. 19. Extortion.

P. 253, wote, $l .2$ from the bottom, for wrongful inundation, read criminal inundation.

P. 285, note, $l .15$, for in the confultative, pre-interpretative (or purely civil) branch of procedure, 1. Mifinterpretation, or adjudication. In the executive (including the penal branch) read, In 
the purely civil branch of procedure, 1. Mifadjudication. In tive penal branch, \&cc.

P. 2S7, note, l. 12, inftead of the fentence beginning Subordination, \&c. read as follows: Subordination on the part of a magiltrate is eitablithed, 1. Where he is made punithable: 2. Where he is made removeable: 3 . When his orders are made reverfitle: 4. When the good or evil, which he has it in his power to produce on the part of the common fubordinate, is lefs in value than the good or evil which the fuperior has it in his power to frostuce, on the part of the fame fordinate.

What follows is now firf printed in January 1789.

P. 12, Cb. 2, [Principles Adverfe] par. XI. By way of note infert as follows:

It ought rather to have been Atiled, more extenfively, the principle of caprice. Where it applies to the choice of actions to be marked out for injunction or prohibition, for reward or punifhment, (to ftand, in a word, as fubjects for obligations to be impoled,) it may indeed with propriety be termed, as in the text, the principle of Jympatby and antipatby. But this appellative does not fo well apply to it, when occupied in the choice of the events which are to ferve as fources of title with refpect to rigbts : where the actions prohibited and allowed, the obligations and rights, being already fixed, the only queftion is, under what circumftances a man is to be invefted with the one or fubjected to the other? from what incidents occafion is to be taken to inveft a man, or to refufe to invelt him, with the one, or to fubjeet him to the other? In this latter cafe it may more appofitely be characterized by the name of the pbastaftic principle. Sympathy and antipathy are affections of the fenfible faculty. But the choice of titles with refpet to rights, efpecially with refpect to proprietary rights, upon grounds unconneeted with utility, 
has been in many inftances the work, not of the affections but of the imagination.

When, in juftification of an article of Englin Common Law, lord Coke produced a fort of ponderofity he had difcovered in rights, difqualifying them from afcending in a ftraight line, it was not that he loved uncles particularly, or bated fathers, but becaufe the analogy, fuch as it was, was what his imagination prefented him with, inftead of a reafon, and becaufe, to a judgment unobfervant of the ftandard of utility, or unacquainted with the art of confulting it, where affection is out of the way, imagination is the only guide.

When I know not what ingenious grammarian invented the propolition Delegatus non poteft delegare, to ferve as a rule of law, it was not furely that he had any antipathy to delegates of the fecond order, or that it was any pleafure to him to think of the ruin which, for want of a manager at home, may befal the affairs of a traveller, whom an unforefeen accident has deprived of the object of his choice : it was, that the incongruity, of giving the fame law to objects fo contrafted as allive and pafive are, was not to be furmounted, and that-alus chimes, as well as it contratts, with -are.

When that inexorable maxim, of which the dominion is no more to be defined, than the date of its birth, or the name of its father, is to be found, was imported from England for the government of Bengal, and the whole fabrick of judicature was cruthed by the thunders of ex-poff-fazto juftice, it was not furely that the profpect of a blamelefs magittracy perifhing in prifon afforded any enjoyment to the unoffended authors of their mifery; but that the mufic of the maxim, abforbing the whole imagination, had drowned the cries of humanity along with the dietates of common fenfe. Fiat Juftitia, ruat calum, fays another maxim, as full of extravagance as it is of harmony : Go heaven to wreck-10 juftice be but done :-and what is the ruin of kingdoms, in comparifon of the wreck of heaven ? 
INTROD. Correc. rions.
So again, when the Pruffian chancellor, infpired with the wifdom of I know not what Roman fage, proclaimed in good Latin, for the edification of German ears, Servitus fervitutis non datur, [Cod. Fred. tom. ii. par. 2. liv. 2. tit. x. 6. p. 308.] it was not that he had conceived any averfion to the life-holder who, during the continuance of his term, Thould with to gratify a neighbour with a right of way or water, or to the neighbour who thould wilh to accept of the indulgence; but that, to a jurifprudential ear, -tus -tutis founds little lefs melodious than -atus -are. Whether the melody of the maxim was the real reafon of the rule, is not left open to difpute: for it is uhered in by the conjunction quia, realon's appointed harbinger: quia fervitus jervitutis non datur.

Neither would equal melody have been produced, nor indeed could fimilar melody have been called for, in either of thefe inftances, by the oppofite provifion: it is only when they are oppoled to general rules, and not when by their conformity they are abforbed in them, that more fpecific ones can obtain a feparate exiftence. Delegatus poteff delegare, and Servitus Jervitutis datur, provifions already included under the general adoption of contracts, would have been as unneceffary to the apprehenfion and the memory, as, in comparifon of their energetic negatives, they are infipid to the ear.

Were the enquiry diligently made, it would be found that the goddefs of harmony has exercifed more influence, however latent, over the difpenfations of Themis, than her moft diligent hiftoriographers, or even her moft paffionate panegyrifts, feem to have been aware of. Every one knows, how, by the miniftry of Orpheus, it was the who firtt collested the fons of men beneath the thadow of the feepter : yet, in the midft of continual experience, men feem yet to learn, with what fuccefsful diligence the has laboured to guide it in its courfe. Every one knows, that meafured numbers were the language of the infancy of law : none feem to have obferved, with what imperious fway they have governed her maturer age. In Englifh jurifprudence in particular, the connestion betwixt law and mufic, how-

ever 
ever lefs perceived than in Spartan legination, is not perhaps lefs real nor lefs clofe. The inufic of the Office, though not of the fame kind, is not lefs mufical in its kind, than the mufic of the Theatre; that which hardens the heart, than that which foftens it:-foftenutos as long, cadences as fonorous; and thofe governed by rules, though not yet promulgated, not lef. determinate. Search indietments, pleadings, proceedings in chancery, conveyances: whatever trefpaffes you may find againit truth or common fenfe, you will find none againit the laws of harmony. The Englifh Liturgy, juftly as this quality has been extolled in that facred office, poffeffes not a greater meafure of it, than is oommonly to be found in an Englin AEt of Parliament. Dignity, fimplicity, brevity, precifion, intelligibility, poffibility of being retained or fo much as apprehended, every thing yields to Harmony. Volumes might be filled, thelves loaded, with the facrifices that are made to this infatiate power. Expletives, her minifters in Grecian poetry, are not lefs bufy, though in different Mape and bulk, in Englifh legination: in the former, they are monofyllables ${ }^{2}$ : in the latter, they are whole lines ${ }^{\circ}$.

To return to the principle of Sympatby and antipatby : a term preferred at firt, on account of its impartiality, to the principle of caprice. The choice of an appellative, in the above respects too narrow, was owing to my not having, at that time, extended my views over the civil branch of law, any otherwife than as I had found it infeparably involved in the penal. But when we come to the former branch, we thall fee the pbantaftic principle making at leaft as great a figure there, as the principle of Smonatby and antipatby in the latter.

In the days of lord Coke, the light of utility can fcarcely be faid to have as yet thone upon the face of Common Law. If a faint ray of it, under the name of the argumentum ab incorvenienti, is to be found in a lift of about twenty topics exhibited by that great lawyer as the co-ordinate leaders of

- Mo, ra, $n$, m, \&c.-

- And be it further enated by the authority aforefaid that-Provided always, and it is bereby forther enatted and declared that-\&c. \&ce. 
INTROD.

that all-perfect fyftem, the admiffion, fo circumftanced, is as fure a proof of neglect, as, to the ftatues of Brutus and Caffius, exclufion was a caufe of notice. It ftands, neither in the front, nor in the rear, nor in any poft of honour; but huddled in towards the middle, without the fmalleft mark of preference. [Coke Littleton. 11. a.] Nor is this Latin inconvenience by any means the fame thing with the Engliph one. It ftands diftinguined from mijcbief : and becaufe by the vulgar it is taken for fomething lefs bad, it is given by the learned as fomething worfe. The law prefers a mifcbief to an inconvenience, fays an admired maxim, and the more admired, becaufe as nothing is expreffed by it, the more is fuppofed to be underfood.

Not that there is any avowed, much lefs a conftant oppofition, between the prefcriptions of utility and the operations of the common law : luch conftancy we have feen to be too much even for afcetic fervor. [Supra, par. x.] From time to time inninet would unavoidably betray them into the paths of reaion : inftinet which, however it may be cramped, can never be killed by education. The cobwebs fpun out of the materials brought together by "the competition of oppofite analogies," can never have ceafed being warped by the filent attraction of the rational principle: though it fhould have been, as the needle is by the magnet, without the privity of confcience.

P. 22. Cb. III. [Sanctions] Art. v. By way of note infert as follows:

[Moral Sanetion.] Better termed pupular, as more directiy indlicative of its connlituent caufe; as likewife of its relation to the more common phrafe public cpinicn, in French opinion publique, the name there given to that tutelary power, of which of late fo much is faid, and by which to much is done. The latter appellation is however unhappy and inexpreffive; fince if opinion is material, it is only in virtue of the influence it exercifes over action, through the medium of the affections and the will.

P. In. Cb. XII. [Confequences; par. XVIII. By way of note infert as follows: 
The inveltigation might, by a procels rendered obvious by analogy, be extended to the confequences of an act of a beneficial nature.

In both inftances a third order of confequences may be reckoned to have taken place, when the influenc: of the act, through the medium of the paffive faculty of the parient, has come to affect his active faculty. In this way, I. Evil may flow out of coil : Intance, The exertions of induftry put a ftop to by the extinction of inducement, refulting from a continued chain of acts of robbery or extortion: 2. Good out of evil : Initance, Habits of depredatita put a ftop to by a fteady courfe of punifhment: 3. Evil out of good: Inltance, Habits of indultry put a ftop to by an exceffive courfe of gratuitous bounty : 4 . Good out of good: Inftance, A conftant and encreafing courfe of induftry, excited and kept up by the rewards afforded by a regular and encrealing market for the fruits of it.

P. 204. Cb. XVI. [Divifion.] par. X. By way of note infert as follows :

Clafs 5. [Multiform or beterogeneous offences. I. Offences by falfood: 2. Offences againft truft.7 See alfo pages 218 to 240, par. XX. to XXX. And page 306, par. LXVI. Maturer views have fuggefted the feafibility, and the means, of ridding the fyftem of this anomalous excrefcence. Inftead of confidering thefe as fo many divifions of offences, divided into genera, correfpondent and collateral to the feveral genera diftinguifhed by other appellations, they may be confidered as to many fpecific differences, refpectively applicable to thofe genera. Thus, in the cafe of a fimple perfonal injury, in the operation of which a plan of falmood has been employed : it feems more fimple and more natural, to confider the offence thus committed as a particular Species or modification of the genus of offence termed a fimple perfonal injury, than to confider the fimple perfonal injury, when effected by fuch means, as a modification of the divifion of offences entitled Offences tbrougb jaifhood. By this means the circumftances, of the intervention of falhood as an inftrument, and of the exiftence of a particular obligation of the nature of a truft, will be reduced to a par with various other 
INTROD:

Correc-

r10No.

claffes of circumftances capable of affording grounds of modification, commonly of aggravation or extenuation, to various genera of offences : Inftance, Premeditation, and confpiracy, on the one hand: Provocation received, and intoxication, on the other.

P. 234. Cb. XVI. [Divifion.] par. XXVII. By way of note infert as follows: [Invefment and Diveftment.] More fimply and characteriftically, as well as more commodiounly for grammatical conftruction, collation and ablation. So afterwards, p. 246, par. $\mathrm{XXXV}$, inftead of inveftitive and diveftitive events, collative and ablative. But on different occafions, each of thefe different fets of terms may have its ufe.

End of the Errata, Corretions, and Additionsta 


\section{$\begin{array}{lllllllll}\text { C } & \mathbf{O} & \mathbf{N} & \mathbf{T} & \mathbf{E} & \mathbf{N} & \mathbf{T} & \mathbf{S} .\end{array}$}

Chap. I. Of tbe Principle of [Utility.]

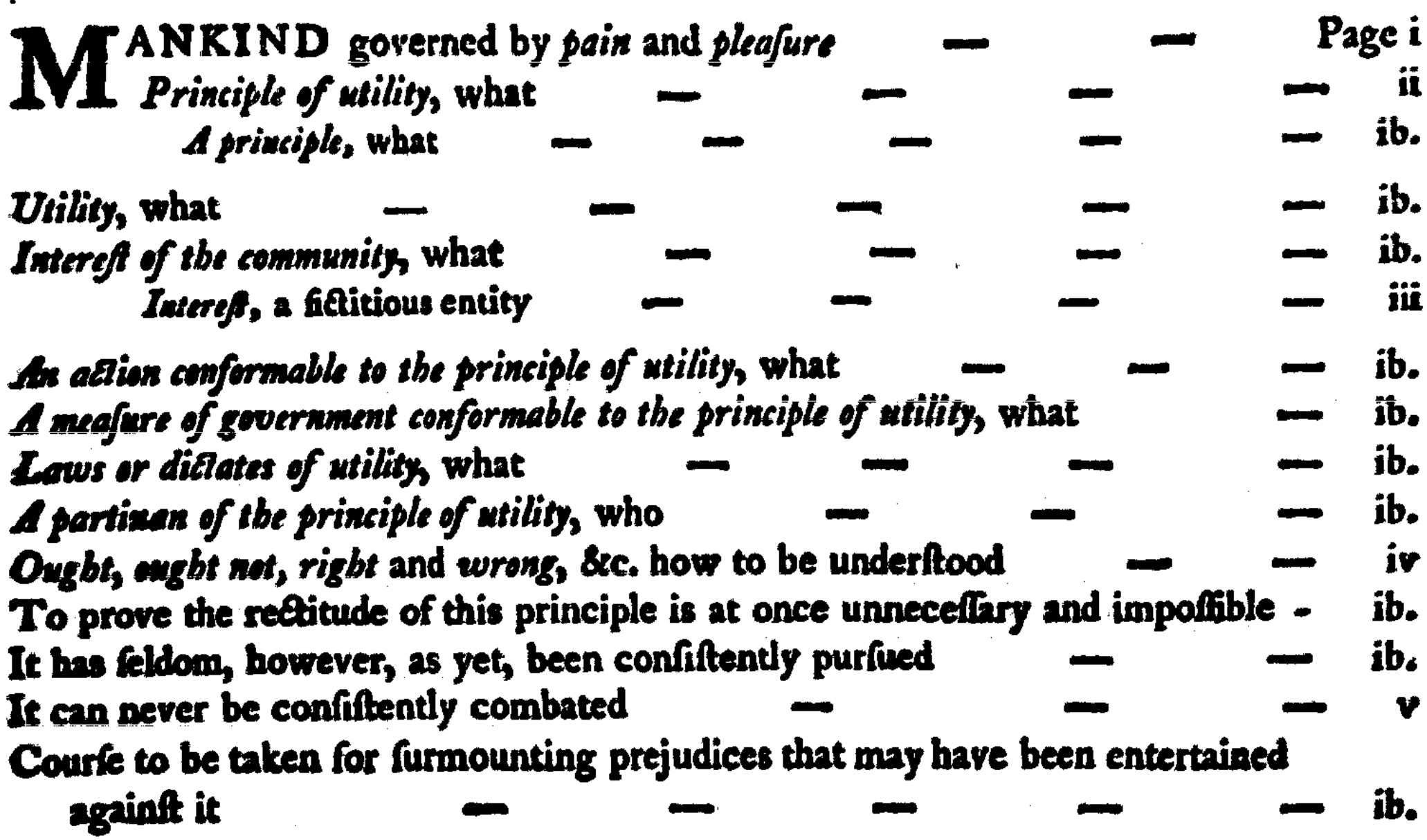

\section{Crap. II. Of [Principles adverfe] to that of Utility.}

All other principles than that of utility mult be wrong Ways in which a prineiple may be wrong - - - - ib. Ascericifm, origin of the word - - - - - ib. Principles of the Monks - $\quad$ - $\quad$ - $\quad$ - ib.

Principle of afcoticijom, what $-\mathrm{Y}_{\overline{2}}-$ - viii 


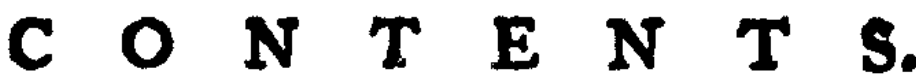

A partixan of the principle of afceticifm, who

Page viii

This principle has had in fome a philofophical, in others a religious origin - ib.

It has been carried farther by the religious party than by the philofophical - ix

The philolophical branch of it has had moft influence among perfons of education, the religious among the vulgar

- $\quad$ - ib

The principle of afceticifm has never been fteadily applied by either party to the bufinefs of government - -

The principle of afceticifm, in its origin, was but that of utility mifapplied -

It can never be confiftently purfued

The principle of fympatby and antipatby, what $-x i$

This is rather the negation of all principle, than any thing pofitive - $\quad$ ib.

Sentiments of a partizan of the principle of antipathy - - $\quad$ xiii

The fyftems that have been formed concerning the flandard of right and wrong,

are all reducible to this principle -

Various phrafes, that have ferved as the charateriftic marks of fo many pre-

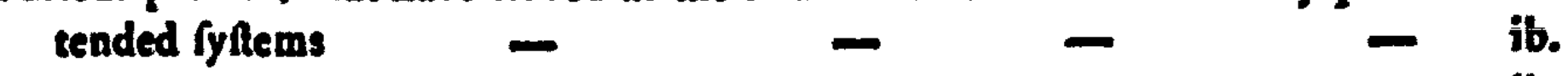

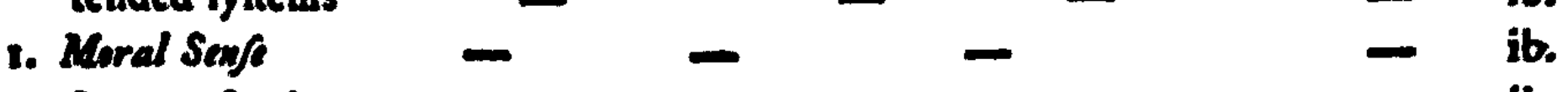

2. Common Senfe $\quad-\quad-\quad-\quad-\quad$ - ib.

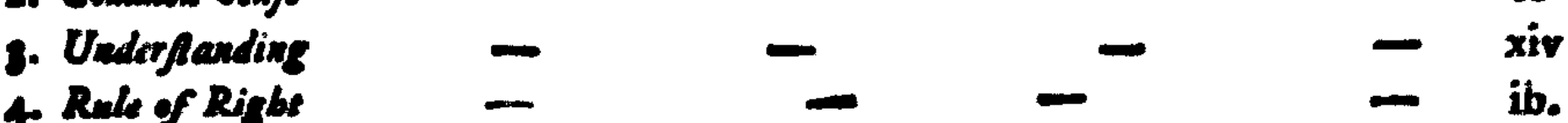

5. Fisuess of Tbings $\quad-\quad-\quad-\quad-\quad-\quad-i b$.

6. Law of Nature - - - - - it.

7. Lase of Reafon, Right Reafon, Natural Yufice, Natural Equity, Good Order ib.

8. Trub - - - - - - ib.

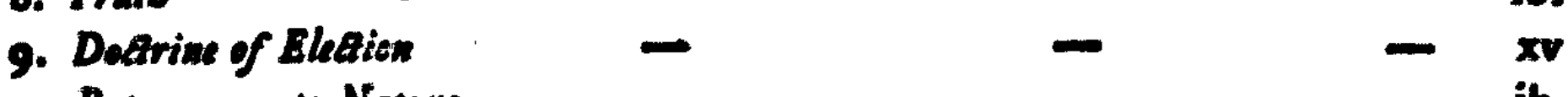

$\begin{array}{llll}\text { 10. Repugaangy to Nature - - } & - & - & \text { ib. } \\ \text { Mifebief they produce } & - & - & \text { ib. }\end{array}$

Whether utility is afually the fole ground of all the approbation we ever beflow, is a different confideration - $\quad-\quad-\quad x v i$

This principle will frequently coincide with that of utility $=-x i v$

This principle is moft apt to err on the fide of feverity - - $\quad$ xvï

But errs, in fome intances, on the fide of lenity - - xviii

The tbeolgical principle, what-not a feparate principle - - ib.

The principle of theology how reducible to one or another of the other three principles - - -

Antipathy, let the actions it dientes be ever fo right, is never of itielf a right ground of ation 


\section{Cha p. III. Of the four [Sanctions] or Sources of Pain and Pleafure.}

Conneation of this chapter with the preceding

Four fanciions or fources of pleafure and pain

1. The plyjfical Gnction

2. The political

3. The moral or popular
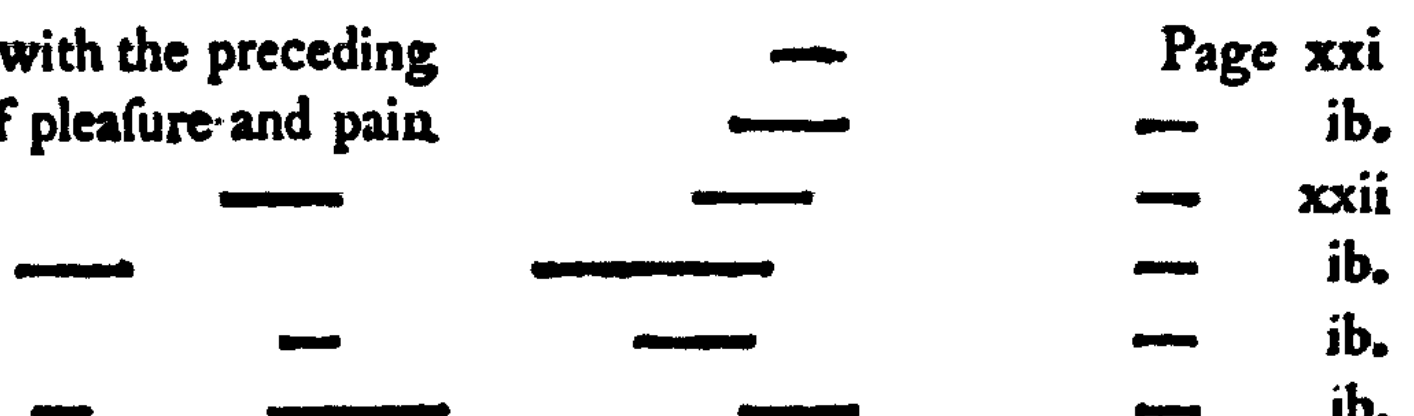

4. The religious

-

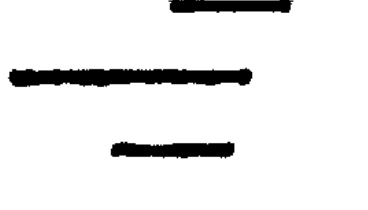

- ib.

- ib.

The pleafures and pains which belong to the religious fanction, may regard. either the prefent life or a future

Thofe which regand the prefent life, from which foever fource they flow, differ

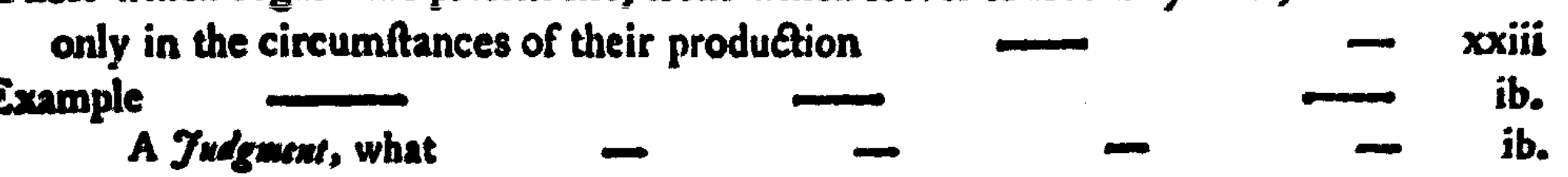

Thofe which regard a future life are tuut fpecifically knnwn - $-\quad$ xxir The phyfical fanction included in each of the other three - $\quad-\quad$ ib. Ufe of this chapter

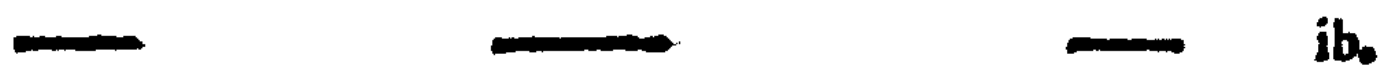

\section{Cha p. IV. [Value] of a Lot of Pleafure or Pain bow to be meafured.}

Ufe of this chapter $\quad$ - $\quad$ - xxvi

Circumitances to be taken into the account in eftimating the value of a pleafure or prin confidered with reference to a fingle perion, and by itfelf - ib.

- confidered as conneeted with other pleafures or pains _ - _ ib.

-confidered with reference to a number of perlons - - xxvii

Procefs for eltimating the tendency of any act or event - - - ib.

Uie of the foregoing procels - - - xxviii

The Gme procefs applicable to good and evil, profit and mifcbicf, and all other ib. modifications of pleafure and pain - - - ib.

Conformity of men's practice to this theory - - - - - ib. 


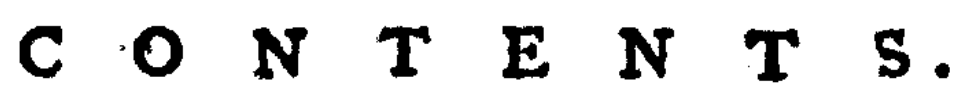

\section{Chap. V. [Pleafures and Pains] their Kinds.}

Pleafures and pains are either, 1. Simple: or, 2. Complex - Page xxx The fimple pleafures cnumerated - ib. The fimple pains enumerated $\quad-\quad$ - $\quad-\quad$ Analytical view, why none given - $\quad-\quad-\quad-\quad x x x i$

1. Pleafures of fenfe enumerated - $-{ }_{-}$ib.

2. Pleafures of wealth, which are either of acquifrtion; or of polfefion - ib.

3. Pleafures of fiill -

4. Pleafures of amity $\quad-\quad$ - $\quad-\quad$ - xoxii

5. Pleafures of a good name - ib.

6. Pleafures of power - $\longrightarrow$ ib.

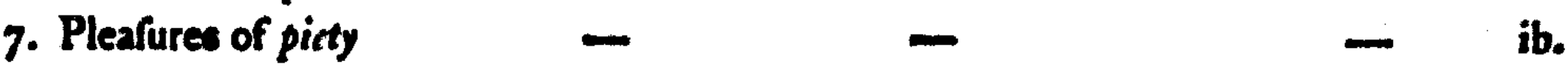

8. Pleafures of bencvolence or good-will - $\quad$ - xxxiii

9. Pleafures of malsuolence or ill-will - $\quad$ ib.

12. Pleafures of the memory $\quad$ - $\quad$ -

11. Pleafures of the imagination - $\quad-\quad-\quad-$ ib.

12. Pleafures of expectation - - -

13. Pleafures depending on affociation - xocxiv

14. Pleafures of relief - - - - ib.

1. Pains of privation - - - ib.

Thefe include, 1. Pains of defire - - - ib.

2. Pains of difappointment - $\quad-$ xockr

3. Pains of regret

No politive pains correfpond to the pleafure of the venereal feufe - ib.

3. Pains of awhwardnefs - - oxorvi

No pofitive pains correfpond to the pleafure of novelty - - ib.

-nor to thofe of wealth - - - - - ib.

Is chis a difinet pofitive pain, or only a pain of privation - ib.

4. Pains of enmity - - - - - $\quad$ ib.

5. Pains of an ill-name - - - ib.

The pofitive pains of an ill name, and the pains of privation, oppofed to

6. Pains of piety - - ib.

No pofitive pains correfpond to the pleafures of power - - ib.

The poffive pains of piety, and the pains of privation, oppofed to the
pleafures of piety, sun into one anocher 


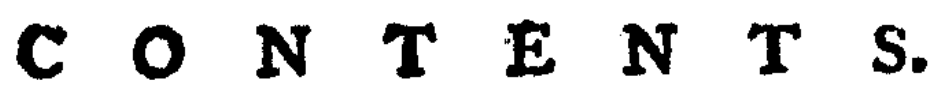

7. Pains of benevolence

8. Pains of malevolence

9. Pains of the memory

10. Pains of the inuagination

11. Pains of expectation

12. Pains of affociation
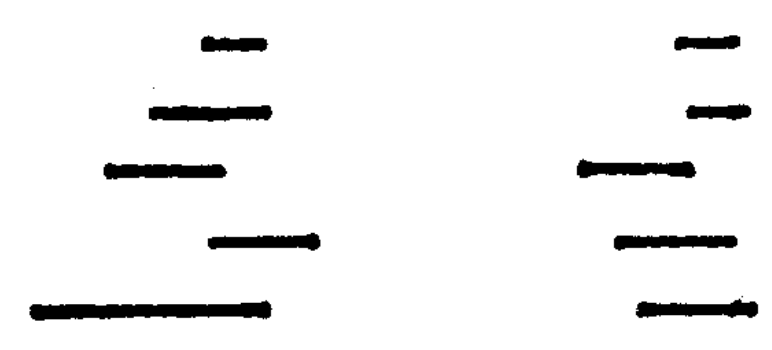

Page xxxvii

Pleafures and pains are cither felf-regarding or extra-regarding

Pleafures and pains of amity and enmity diftinguilhed from thofe of benevolence and malevolence - - -

- $\quad$ ibxviii

- ib.

- ib.

- ib.

- ib.

In what ways the law is concerned with the above pains and pleafures

Comples pleafures and pains omitted, why - - - $\quad$ - xxxix

Specimen. Pleafures of a country profpeet _ - - _ - ib.

\section{Cha p. VI. Of Circumftances influencing [Senfibility.]}

Pain and Pleafure not uniformly proportioned to their caufes

Degree or quantum of fenfibility, what

Bias or quality of fenfibility, what

Exciting caules pleafurable and dolorific

$-\quad \mathbf{x l}$

Circumfances infuencing fenfibility, what

Circumfances influencing fenfibility enumerated

Extent and intricacy of this fubjet

1. Healtb

2. Strengtb
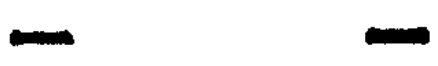

$-$

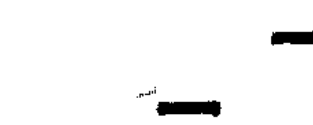

Meafure of Arengtb, the weight a man can lift Weatinefs, what

3. Hardinefs

Difierence between frength and hardinef

4. Bodity imperfation

5. Quantity and quality of knowledge

6. Strengtb of intelletiual powers

7. Firmends of mind

8. Stcadingss

9. Bent of inclinations

10. Moral fenfibility

11. Moral biafes

12. Roligious fonfobility

13. Religiens biofes

14. Sympatbotic fenfibility

15. Sympatbetic biafes

16, 17. Antipatbetic fomfribility, and biafes
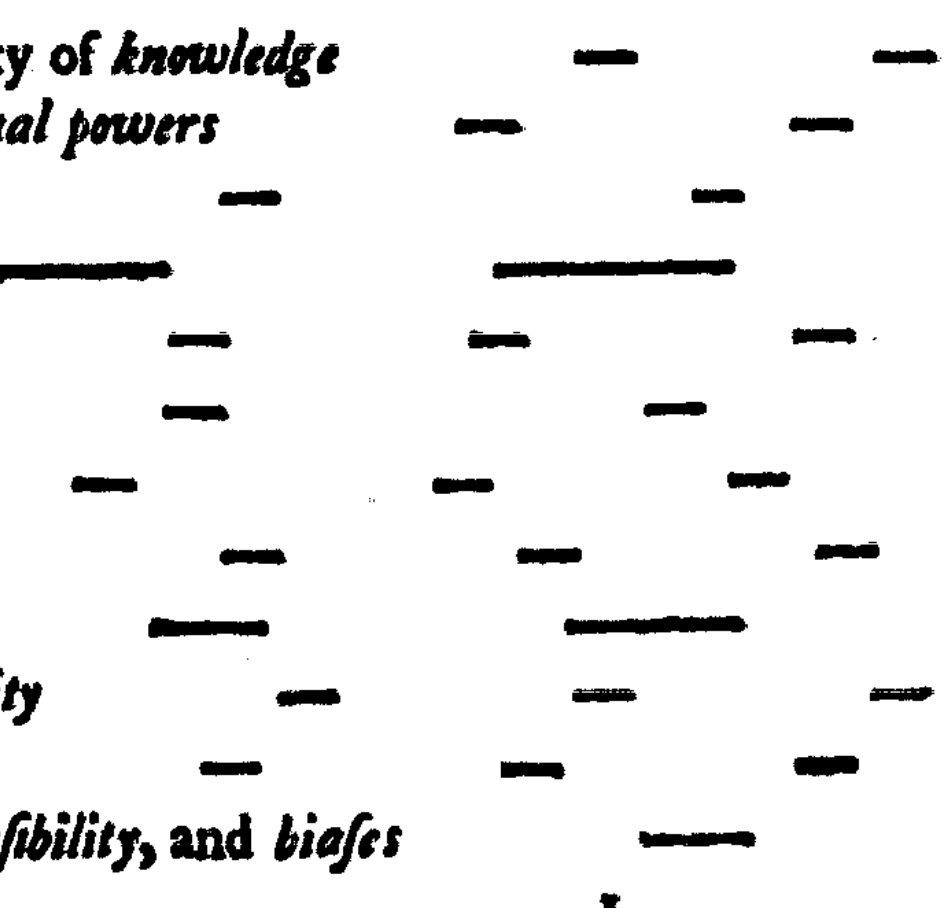

- ib.

- it.

- xii

- io.

- ib.

- xli.

- xliii

- ib.

- ib.

- xliv

- xliii

- xlir

- ib.

- xly

- ib.

- ib.

- xlvi

- ib.

- xlvii

- ib.

- ib.

- xlviii

- ib.

- ib.

- ib. c8. $I t t^{\circ}$ 


\section{$\begin{array}{lllllllll}C & 0 & N & T & E & N & T & S .\end{array}$}

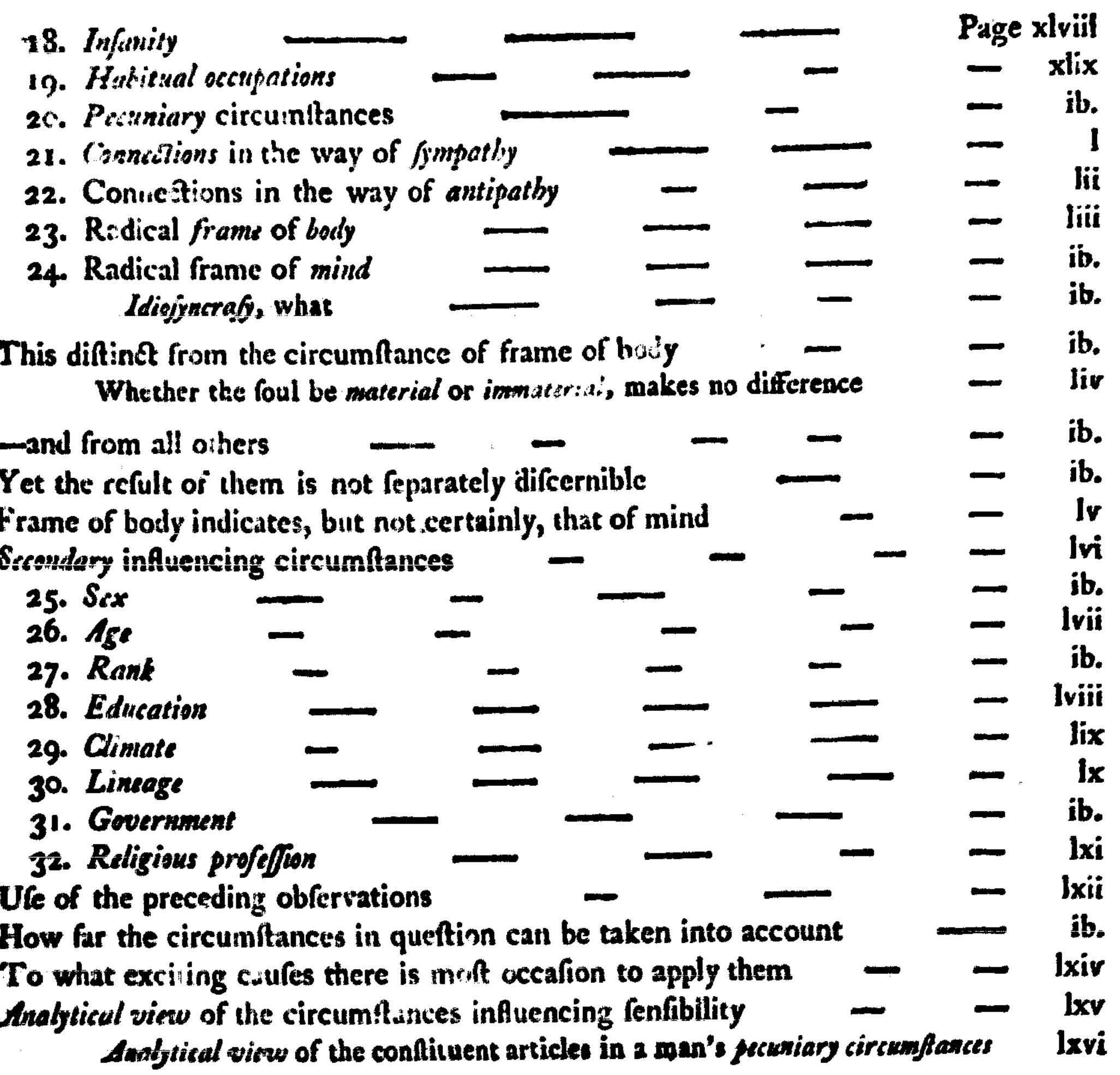

\section{$\mathbf{C}_{\text {HA P. VH. Of buman [Actions] in general. }}$}

The demond for punifoment depends in part upon the tendency of the act - lxvii Tende:cy of an aet determined by its confequences - - - ib. Material confequinecs only are to be regarded - - - - ib. Thefe depend in part upon the intention - - - Ixviii The intenti in depen's as well upon the underfanding as the will - ib. In an action uru to be confidered, $x$. The at. 2. The circunftances. 3. The intersisulatity. 4. The confcioufnefs. 5. The metives. 6. The difpofition - ib. Alts pefstive and negative Ato of amilfore are fill als - - - - ib. 


\section{$\begin{array}{llllllllllll}C & O & N & T^{*} & E & N & T & S .\end{array}$}

Negative acts may be fo relatively or abfolutely - - - ;. Page Ixix

Negative acts may be expreffed pofitivelys and vice verfa - - - lixx

Atts external and internal - $\quad-\quad$ - $\quad$ -

Acts of difcourfes, what - - - - - ib.

Fixternal aets may be tranfitive or intranfitive. - - - - ib.

Ditindion between tranfitive aets and intranfitive, recognized by gram- ib. marians - - - - ib.

A tranfitive att, its commencement, termination, and intermediate progrefs - Lxxi

An intranfitive act, its commencement, and termination - -

Als tranfient and continued - - - - lxxii

Difference between 2 continued ati and a repetition of acts - - ib.

Difference between a repetition of acts and a babit - - - ib.

Aets are indivifible, or divifible, and divifible, as well with regard to matter as

to motion - - - - - - loxiii

Caution refpeting the ambiguity of language - - - ib.

Circumplances are to be confidered - - - - ib.

Corcumplances, what - - - - Loxiv

Circumglances, archetypation of the word - - - ib.

Circumftances matertal and immaterial - - - ib.

A circumitance may be related to an event in point of caufality, in four ways, vix. x. Production. 2. Derivation. 3. Collateral connetion. 4. Conjunet infumence - - - - - - ib.

Example. Affefination of Buckingham - - -

It is not every event that has circumftances related to it in all thole ways - borvi

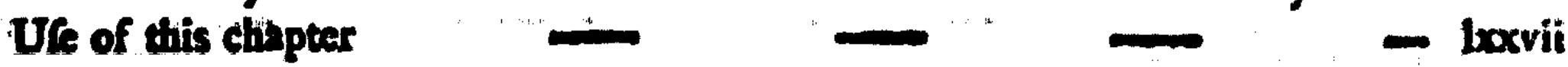

\section{Chap. VIII. Of [Intentionality.]}

Recupitulation -

The intention may regard, $x$. The at: or, 2. The confequences - ib.

Ambigaity of the words voluneary and involuntary - - ib.

It may regard the at without any of the confequences - - - ib.

-or the confequences without regarding the att in all its ftages - $1 \times x \times x$

-but not without regarding the firft ftage. - - - - ib.

An at maintentional in its firt thage, may be fo with refpeat to, 1. 2uan-

A confequence, when intentional, may be direetly fo, or obliquely __ loxoxi

When diredily, whimately for or mediately - - - $\quad$ ib.

Z $2 \quad$ When 


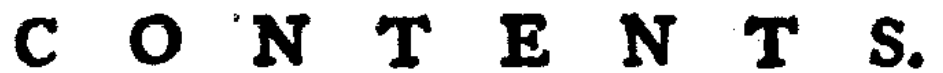

When direally intentional, it may be excluffoely fo, or inexcluffuety Page Ixxxii When inexclufively, it may be conjundively, disjunetively, or indifcriminately fo ib. When disjunctively, it may be witb or without preference - - ib. Difference between an incident's being unintentional, and disjunetively insentional, when the election 7 is in favour of the other _ - ib.

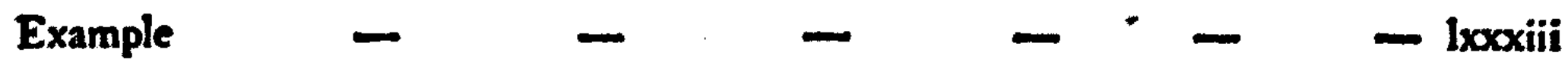
Intentionality of the ad with refpest to its different flages, how far material - Ixxxiv

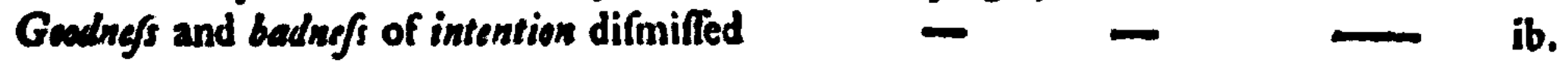

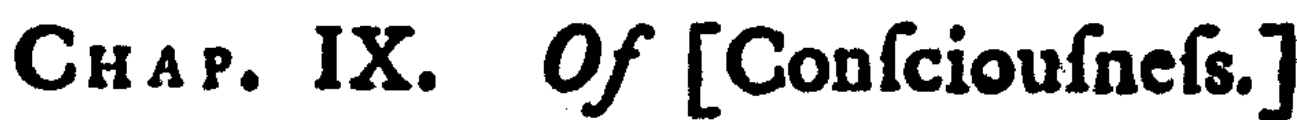

Connedtion of this chapter with the foregoing Aes advifed and unadvifed: confcioufnefs, what Unadvifednefs may regard either exiftence, or materiality - $-\quad$ - ib. The circumitance may have been prefont, paff, or future - - ib. An unadvifed at may be beedlefs, or not beedlefs A mif-adoifod as, what.-a mif-fuppofal. - lxxxvii The fuppofed circumfance might have been material in the way either of prevention or of compenfation - - ib.

It may have been fuppoled profout, paft, or future Example, continued from the laft chapter - - _ ib.

In what cafe confeioufnefs extends the intentionality from the act to the confe. quences

Exmple continued

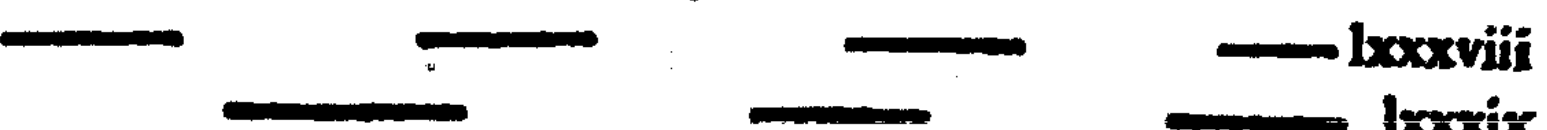

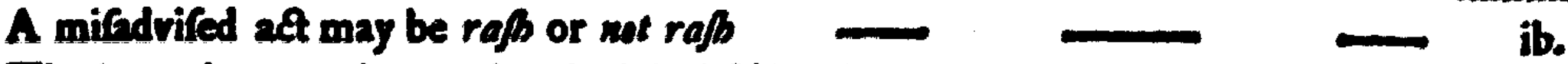

The intention may be good or bad in iffalf; independently of the motive as well as the eventual confequences

It is better, when the intention is meant to be fpoken of as being good or bad, not $20 \mathrm{~Gy}$, the motive

Example

Intention, in what cafes it may be innocent - - _ - ib.

Intentionality and confciournels how fpoken of in the Roman law __ ib.

Ufe of this and the preceding chapter -

\section{Chap. X. Of [Motives.]}

5 1. Different fenfes of the word motive.

Matives why confidered 


\section{$\begin{array}{llllllll}C & O & N & T & E & N & \mathbf{T} & \text { S. }\end{array}$}

Motives to the will

\section{fenfos of the word}

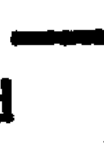

Motives interior and exterior

Motive in profpel -motive in $9 / \int_{0}$.

Motives immediate and remole

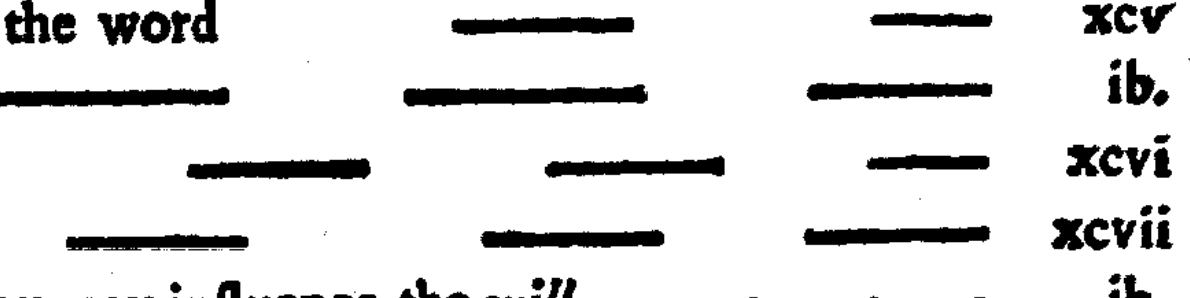

Motives to the underfanding how they may influence the will

\section{No motives eitber conflantly good or conftantly bad.}

Nothing can att of itfelf as a motive, but the idea of pleafure or pain . xcviii No fort of motive is in itfelf a bad one - _ _ ib. Inaccuracy of exprefitions in which good or bad are applied to motives - xcix Any fort of motive may give birth to any fort of at _- _ ib. Dificulties which ftand in the way of an analyfis of this fort _- - ib.

\section{Catalogues of motives correfponding to that of Pleafures and Pains.}

Pbyfical dofire correfponding to pleafures of fenfe in general $\rightarrow-c i i$ The mative correfponding to the plewfures of the palats _ _ _ ib. Vemeral defire correfponding to the pleafures of the venercal fenfe ___ ciii Curigisy, 8ze. correfponding to the pleafures of curights _ _ ib.

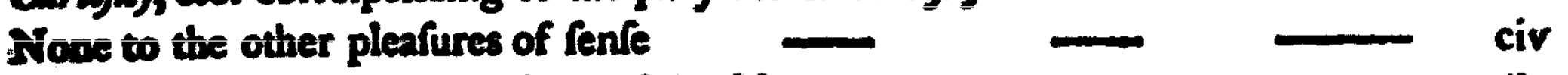
Pacuivian intergft to the pleafures of weallb - _ _ _ _ _ ib. None to the pleafures of fkill __ _ _ ib. To the pleafures of amily, the defore of ingratiating one's felf - - - ib. To the plegfores of a goad name, the love of reputation _ - cV To the shefures of pewer, the love of pewer _ _ _ c criii The mive belonging to the religious fanction - _ Gad-will, 8x. to the pleafures of fympatby - _ _ _ _ cix III-will \&ec. to the pleafures of antipatby self-profervation, to the feveral kinds of pains ___ cxii To the pains of exertion, the love of eafe - - cxiv Motives can only be bad with reference to the moft frequent complexion of their offegs

How is it that matives, fuch as luf, avarice 8xc. are conftantly bad cxv

Under the above reftrietions, motives may be difinguilhed into goed, bad, and indifferent or neutral

Inconveniences of this diftribution

It is only in individual infances that motives can be good or bad _ cxvii

Motives diftinguilhed into focial, difocial, and felf-regarding $\quad$ ib.

- locial, into purcly-focial, and ferwi-focial - cxviii

$$
Z_{Z 2} \quad 5+O_{r}
$$




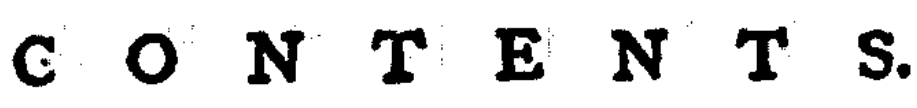

\section{\$4. Order of pre-eminence among motives.}

The dictates of good-will are the fureft of coinciding with thofe of utility Page cxviii Laws and dietates conceived as iffuing from motives $\quad-\ldots \quad$ ib.

Yet do not in all cafes - - - -

Next to them come thore of the love of roputation : - $-c x x$

Next thofe of the dofire of amity cxxi

Diffeulty of placing thofe of raligion

Tendency, they have to improve cxxiii Afterwards come the falf-regarding molives : and, laftly, that of difpleafure - cxxiv

\section{\$ 5. Confict among motives.}

Motives impelling and refroining, whet

What are the motives moft frequently at variance

Example to illuftrate a fruggle among contending motives $-\quad-\quad-i b$.

Practical ufe of the above difquilitions relative to motives _ - coxvi

\section{Cha P. XI. of buman [Difpofitions] in general.}

\section{Difpertions what.}

-

How far it helangs to the prefent fubjeet - ib.

A mifcbiovous difpoffion; a meritorious difpofition; what $-\infty-$ croix

What a man's difpofition is, can only be matter of prefumption - ib.

It depends upon what the act appears to be to him - - - - - ib.

Which pofition is grounded on two faet : $x$. The correfpondence between

intentions and conforusuces - - - - - $\quad-\quad \mathbf{c x a x}$

2. Between the intentions of the fame perfon at different times - ib.

A difpefition, from which proceeds a habit of doing mischief, connot be a good one

The difpofition is to be inferred, 1 . From the apparent tendency of the at:

2. From the nature of the motive

Cafe 1. Tendency, gad-motive, felf-regarding

Care 2. Tendency, bad-motive, folf-regarding

Cafe 3. Tendency, good-motive, goad-will

Cafe 4. Tendency, bad-motive, gead-u ill

This cafe not an impofifble one

Exomple I.

Example II.

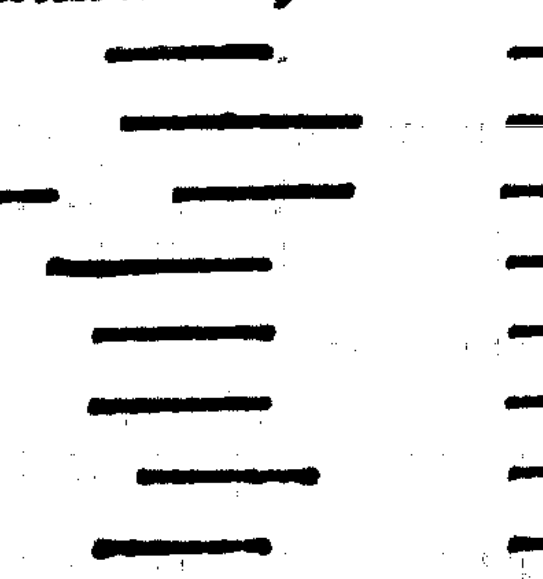

exxxi

ib.

ib.

ib.

cxxxii

ib.

ib.

croxiii

Example 


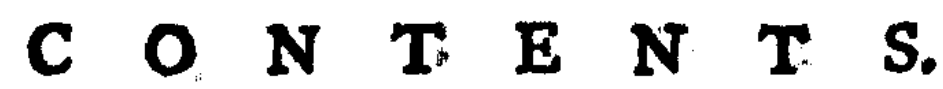

Example IIL.

Care 5. Tendency, good-motive, love of reputation

The bulk of mankind apt to depreciate this motive - ib.

Cafe 6. Tendency, bad-motive, love of reputation - - ib.

Example I. - - - - cxoxv

Example II. , -

Cafe 7. Tendency, goodmmotive, piety - $\quad$ - $\quad$ -

Care 8. Tendency, bad-motive, piety - - - exxxvi

The difpofition may be bad in this cafe - - - - - ib.

Care 9. Tendency, good-motive, malevolence - cxxxviii.

Example - - - - - - - ib.

Care 10. Tendency, bad-motive, malevolence _- - cxoxix

Example - - - - - ib.

Problem-to.meafure the depravity in a man's difpolition - - ib.

A man's difpofition is conftituted by the fum of his insentions - ib.

-which owe their birth to motives : - - $\quad$ - $\quad$ -

A feducing or cerrupting motive, what- tutelary or prefervatory motive - cxl

Tutelary motives are cither fanding or occaffonal - - - - ib.

Standing turdary motives are, 1. Gool-will - - - ib.

2. Thie bove ur icpucation - cxli

3. The defire of amity - $\quad-\quad$ ib.

4. The motive of religion - - cxlit.

Occefomal tutelary motives may be any whatfoever - coliii

Motives that are particularly apt to aet in this character are, 1. Love of eafe.

2. Self-prefervation

Dangers to which folf-prefervation is moft apt in this cafe to have. refpect, are, 1. Dangers purely pbyfical. 2. Dangers dippending on detedion -

Danger depending on deteetion may. refult from, 1. Oppefition on the fpot:

2. Subfequent punifoment w........ - -

The force of the two ftanding tutelary,motives of love of reputation, and defire of amity, depends upon detection - - -

strimgtb of a temptation, what is meant by it - -

Indications afforded by this and other circumftances refpeting the depravity of an offender's dirpointion - - - - -

Reves for meafuring the depravity of difpofition indisated by an offence -

Uife of this chapter

ib.

ib.

cxliv

ib.

ib.

cxlv

Cxlvi

cxlviii

CBAP. 


\section{$\begin{array}{clllllll}\mathbf{C} & \mathbf{O} & \mathbf{N} & \mathbf{T} & \mathrm{E} & \mathbf{N} & \mathbf{T} & \mathrm{S}\end{array}$}

\section{- CH A P. XII. Of the [Confequences] of a mifcbievous aEz.}

$\$$ 1. Sbapes in wobicb the mifcbief of an at may shew itfelf.

Recapitulation

Mifchief of an act, the aggregate of its mifchievous confequences -

The milchief of an ast, primary or fecondary

Primary-original or derivative

The fecondary-1. Alarm: or, 2. Danger

Example - - ib.

The danger wbence it arifes-a paf offence affords no diret motive to ib. fucture cli

But it fuggefts feaftility, and weakens the force of rgfraining motives $-\quad$ clii

viz. 1. Thofe iffuing from.the politital cundion -

2. Thofe iffuing from the moral _ _ cliii

It is faid to operate.by the infinence of example - - ib.

The alarm and the danger, chowgh councered, are dyftinguifbable - cliv

Both may have refpedt to the fame perfon, or to otbers - _ - ib.

The primary confequences of an at may be mifebivoous, and the fecendars,

Analyfis of the different Bopes in which the mifchief of an act may thet itfelf

-applied to the preceding cares - - w elvi

-to examples of other cales where the mifchiof is lefs confpicurous - ib.

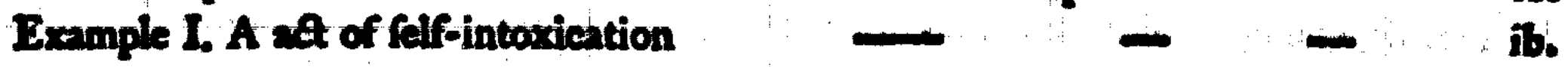

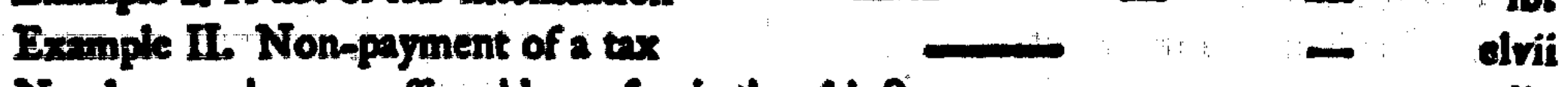

No alarm, when no affignable perfon is the objed $\quad-\ldots+c l i x$

52. How intentionality, Bc. may infuence tbe mifcbief of an act.

Secomans mifchief influenced by the fiate of the agent's mind - cla

Care 1. Involuntaringes - - - - ib.

Cafe 2. Univentionality with beedlefsuefs. - cla

Cais 3- Mij/uppefal of a compleat juffification, without ralhnels - - ib.

Cafe 4. Mifluppofal of a partial juftification, without rafhneis _ - ib.

Cafe 5. Miffuppofl, with rafsmefs - - - c - clxii

Cafe 6. Confequences campleatly intentional, and free from mif-fuppofal ib.

The mature of a motive takes ant owey the mifchief of the fecondary confe-

quences $\quad-\quad-\quad-\quad-\quad-\infty$ ib. 


\section{$\begin{array}{llllllll}C & \mathbf{O} & \mathbf{N} & \mathbf{T} & \mathbf{E} & \mathbf{N} & \mathbf{T} & \mathbf{S} \text {. }\end{array}$}

Nor the beneficialnets.

- Pageclxiii

But it may aggravate the mifchievoufnefs, where they are mifchievous - ib.

But not the moft in the cafe of the worf motives - _ ib.

It does the more, the more confiderable the tendeng of the motive to

produce fuch acts.

-which is as its frongtb and conflancy - - - clxiv

General efficacy of a fpecies of motive, how meafured _ _ _ ib.

A milchievous act is more $\mathrm{fo}$, when iffuing from a falf-regarding than when

from a diffocial motive

- Co even when ifluing from the motive of religion

Connection of this with the fucceeding chapter _ _ ib.

\section{Снат. XIII. [Cafes unmeet] for puni/bment.}

\section{General view of cafes unmeet for punibment.}

The end of law is, to augment happiners - - clavi But punilhment is an evil - - _ - ib.

What concerns the end, and feveral other wopics, relative to ponilhment,

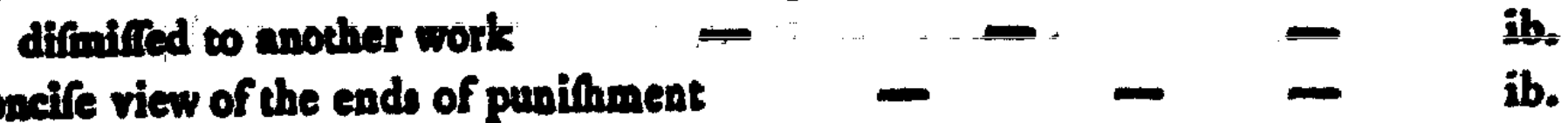

Therefore ought not to be admitted - - $\quad-\quad$ clxvii

1. Where groundlefs " - - - - ib.

2. Inefficacions - - ib.

3. Univitiable - - ib.

4. Or medilofs - - - - ib.

S2. Caffs in wbich punifoment is groundlefs.

1. Where there has never been any milchief: as in the cafe of confent -

2. Where the mifchief was cutweigbed: as in precaution againit calomity, and the exercife of powers - - clusvii

3-or will, for a certainty, be cuned by compenfation - - ib.

Hence the favour thewn to the offences of refponfible offenders: fuch as finple mercantile frauds

$$
\text { - }
$$

9. 3. Cafes in wbicb puniloment muft te inefficacious.

3. Where the penal provifion comes to late: as in 1 . An ex-pof-factolaw

2. Or is at made knoum: as in a law not fuffeiently promalgated

ib. 


\section{C $\quad$ O N $\mathrm{N}$ T E N T S}

3. Where the will cannot be deterred from any aetas in, [a] Infandy - Page clxix

[b.] Infanity $\quad-\quad$ ijb:

[c.] Intswication

In infancy and intoxication the cafe can hardly be proved to come under the rule $\quad-\quad$ - ib.

The reafon for not punithing in thefe three cefes is commonly put upon a wrong footing - clax

4. Or not from the individual act in queftion, 25 in, $\ldots, \ldots+$ ib.

[a] Unintentiality

[b] Uncoufcioufrefs $\quad$ -

[c] Miffuppafal - - - - - ib.

5. Or is acted on by an oppofite fuperior force: as by, - ib.

[a] Pbyfical danger - clxxi

[b] Tbreatencd mifsbief - - - ib.

Why the induence of the moral and religion fandions is not mencioned
in the fame view

6. -or the batily ergens cannot follow its determination: as under pbyfical sompulison or refiraint - -

\$. Cajes wobere punghiment is unfrofitable.

1. Where, in the fort of cafe in queftion, the punilhment would produce mose evil than the offence would -

Evil producible by a punifbunt-its four branches-viz. [a] Refraint - clroib

[b] Apprebension

[c] Suffrance - - - ib.

[d] Derivative evils

The evil of the effince, being different according to the nature of the of-

fence, cannot be reprefented here -

2.-Where, in the individual cafo in queftion: by reafon of -

[a] The multitude of delinquents - - -

[b] The value of a delinguent's fervice - eloxiii

[c] The diphagiure of the people _- - _ - ib.

[d] The difpleafure of forcign pewers . - _ _ ib.

5. Cafes wbere punifoment is needlefs.

1. Where the mifchief is to be provented at a cheaper rate: as by inArueica

ib.

Crar. 


\section{Chap. XIV. Of the [Proportion] between punifhments and offences.}

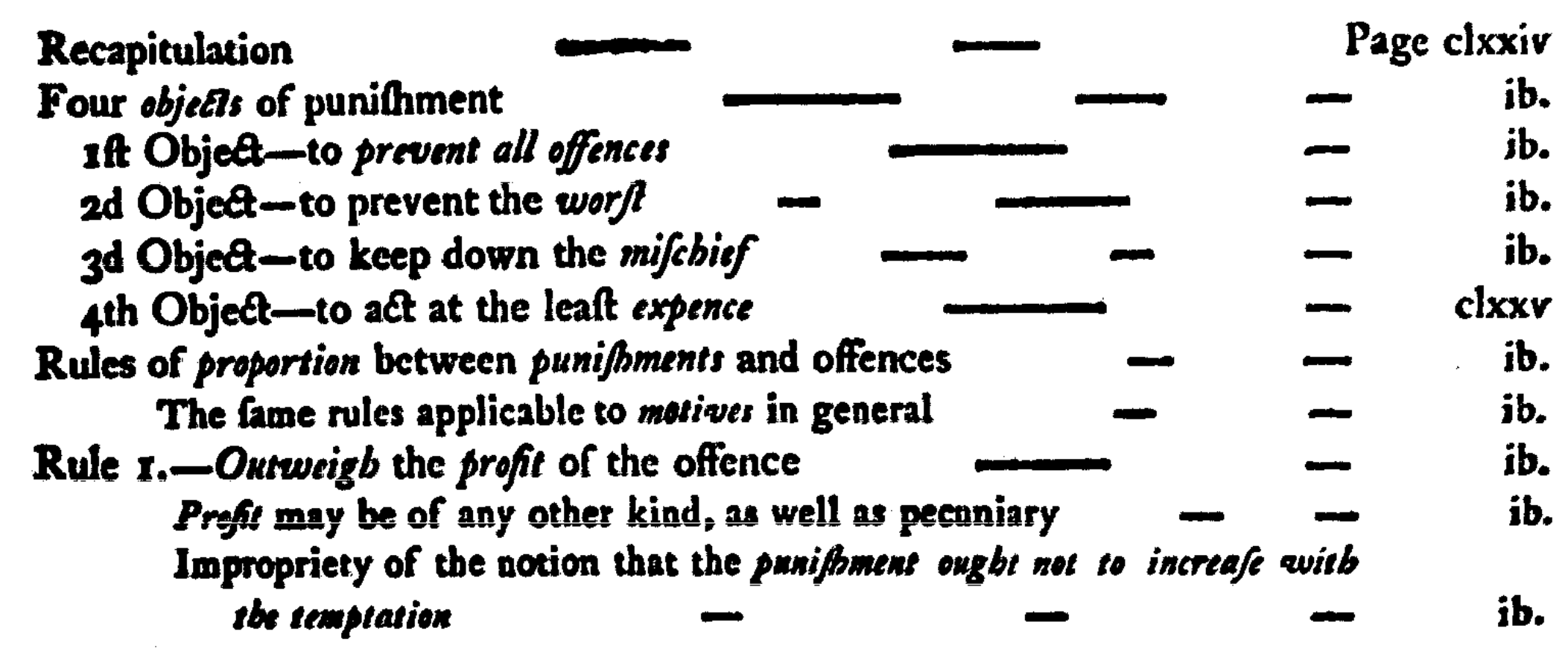

The propriety of taking the frengtb of the temptation for a ground of abatement, 10 ofjertion to this rule

Rule 2. - Venture more againlt a greuc unusuc than a forall one, -

Example.-Inceudiarifon and coining

Rule 3-Caufe the lea $\Omega$ of two offences to be preferred _ -

Rule 4-Punifh for cacb particle of the mifchief
Example.-In blows given, and money ftolen

Rule 5.-Punith in no degree without Special reafon

Rule 6. -Attend to circumftances infuencing fenfibility

Comparative view of the above rules

$-2$

Into the account of the value of a punifhment, mut be taken its deficiency in point of certainty and proximity

Allo, into the account of the milcbief, and proft of the offence, the mifchief and profit of otber offences of the fame babit

Rule 7.-Want of certainty muft be made up in magnitude.

Rule 8. - So allo want of proximity

-

Rule 9.-For ads indicative of a habit, punilh as for the babit

The remaining rules are of lef's importance

Rale 10.-For the fake of quality, increafe in quentily

Rule 11.-Particularly for a moral leffon

A puniforeme appltied by way of mural lafien, what

Bxample-In fimple corparal injuriet

Example-In military lows clxxvi

clxxvii

ib.

clxxviii

ib.

ib.

ib.

clxxix

ib.

ib.

clexxx

ib.

clxxxi

ib.

is.

ib.

ib.

ib.

clxxxii

ib.

Rule. 


\section{C $O \quad N \quad T E R$ N $\mathrm{N}$ T}

Rule 22.-Attend to circumftances which may render punifhment unpro-

fitabile
Proportionality carried very far in the prefent work-why
uxiliary force of the phyffical, moral, and religious fangions, not here al-
lowed for-why

\section{Cн а P. XV. Of the [Properties] to be given to a lot of purijbment.}

Properties are to be governed by. proportion.

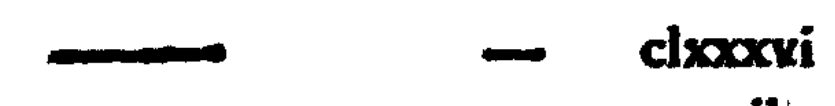

Property 1. Variability

Property 2. Equability.
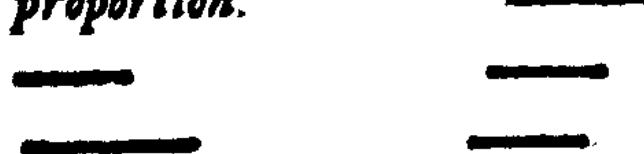

ib.

Punifhments which are apt to be deficient in this rerpeet - ib.

Property 3. Commenfurability to other punifhments - - clxoxviii

How two lots of punithment may be rendered perfeelly commenfurable ib.

Property 4 Charallerifticalnefs - clacoxix

The mode of punithment the moft eminendy. characteriftic, is that of retaliation - - ib.

Property 5. Exemplarity - cxe

The moft effeetual way of rendering a punihment exemplary is by means of analogy - - - ib.

Property 6. Frugality - - exci

Frugality belongs in perfection to pecuniary punifbment - - ib.

Exemplarity and frugality in what they differ and agree - - $\quad$ ib.

Other properties of inferior importance - cxcii

Property 7. Subferviency to reformation - $\quad-\quad$ - ib.

- spplied to offences originating in ill-will - cxciii

-to offences originating in indolence joined to pecuniary intereft - ib.

Property 8. Efficacy with respect to difablement - -

-is moft conficuous in capital punifhment - - $\quad$ - exciv

Other punithments in which it is to be found - - - ib.

Property 9. Subferviency to compenfation -

Property 10. Popularity - - - ib.

Charateriticalnefs renders a punifhment, 1. memorable: 2. exemplang:
3. copular

2Lifcbifss refulting from the enpopularity of a punifhment-difcontent among

the people, and weaknefs in the law - - - ib.

This property fuppores a projudice which the legilature ought to cure - cxcri 


\section{$\begin{array}{llllllllllll}C & O & N & \mathbf{T} & \mathbf{E} & \mathbf{N} & \mathbf{T} & \mathrm{S} .\end{array}$}

Property 11. Remiffbility

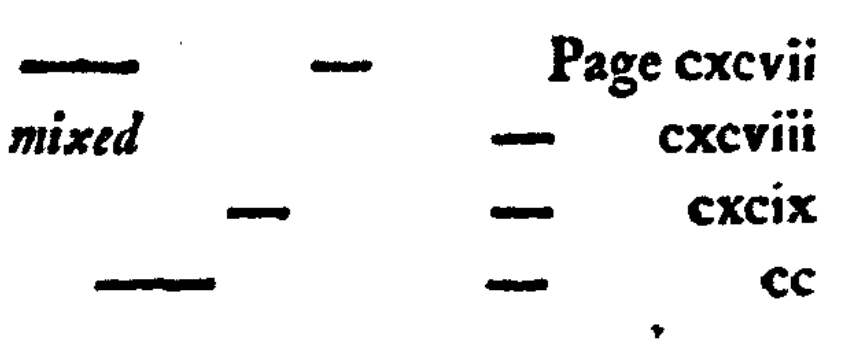

To obtain all thefe properties, punifhments mult be mixed - cxcriii

The foregoing propertics recapitulated
Connection of this with the enfuing chapter

\section{Cha p. XVI. [Divifion] of offences.}

\section{$\$$ 1. Clafjes of offences.}

Metbod purfued in the following divifion

\section{-}

Diftinction between what are offences and what ought to be

To be fo, it mult be detrimental to fome one or more of its members - ccii

Thefe may be affignable or not - - - - ib.

Perfons affigable, how - - ib.

If affignable, the offender himfelf, or otbers - $\quad$ - $\quad-\quad$ cciii

Clats 1. Private offences - _ - -

Clais 2. Semi-public offences _- - - _ ib.

Limits between private, femi-public, and public offences, are, frialy
fpeaking undinioguifhable

Clars 3. Self-regarding offences . - - - - ecir

Chis 4. Public offences - ib.

Clafs 5. Multiform offences, viz. 1. Offences by fallsood. 2. Offences

The imperfections of language an obftacle to arrangement - - ib.

Irregularity of chis clars - - cer

- which could not be avided on any other plan. [See tbe Beet of correctinus, in ewbicb tbis clafs is expenged.]

ib.

\$2. Divifions and fub-divifions.

Divifions of Class 1. 1. Offences againt perjon. 2-Reputation. 3-Property. 4-Condition. 5-Perfon and reputation. 6-Perfon and property

In what manner pleafure and pain depead upon the relation a man bears w exterior objets -

2. Offences of mere delinquency, how they correfpond with the divifions of private offences - _ - _ - ib.

Divifions of Clafs 3. coincide with thofe of Clafs 1. - - - ib.

Divifions of Clars 4 . - - - ccx

Exbayfize method departed from _- - $\quad$ - ib.

Conmedion of the nine firft divifions one with another - $\quad$ ccxi

Conneation of offences againt religion with the foregoing ones - ccrvi

$$
3 \mathrm{~A}_{2} \quad \text { Connection }
$$




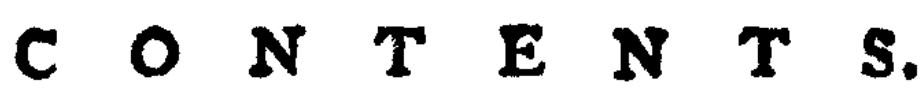

Connoction of offences againft the national intereft in general with the reft Page ccxviii Sub-divifions of Clafs 5. enumerated

1. Divifions of offences by falbood

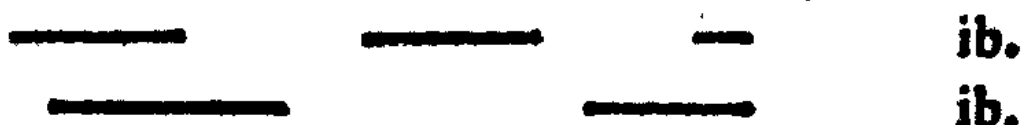

Sub-divifions of offences by falbood are determined by the divifions of the preceding claftes - _ _ - -

Offences of this clafs, in fome inftances, change their names; in others, not

A truff, what

Power and rigbt, why no compleat definition is here given of them

Offences againft truft, condition, and property, why ranked under feparate divifions

Offences againft truß-their connection with each other -. -

Prodigality in truflces difmifled to $\mathrm{Cla} / \mathrm{s} 3$.

The fub-divifons of offences againf truft are allo determined by the dilitions of the preceding claftes -

of the preceding claffis
Conncelion between offences by falbood and offences againfl truf/

\section{Genera of cla/s I.}

Amalyfis into genera purlued no turther than Claís I.

Offences againft an individual may be fumple in their effects, or complex -

Offences againg/2 perfon-their genera

Offences againtt reputation

Offences againft property

Payment, what

Offences againft perfon and roputation

Offences againft perfon and property

Offences againft condition.-Conditione domefic

Domefic conditions grounded on natural relatic or

Relasions-rue refult from every two objeets

Domeftic relations which are purcly of legal inflitution

Offences touching the condition of a mafer

Various mades of fervitude

Offences touching the condition of a fruant

Guardian/bip, what-Neceffity of the inftitution

Duration to be given to it

Powers that may, and dutics that ought to be, annexed to it

Offences touching the condition of a guardian -

Offences touching the condition of a ward
Offences touching the condition of a parent

Offences touching the fitial condition

Condition of a bufband. - Powert, dutties, and rights, that may be annexed to it ib.

$\operatorname{ccxx}$

ib.

cexxi

ib.

exxxviii

ib.

$\operatorname{cod}$

ib.

cexli

cexliv

cexly

cexlvi

ccli

cclii

celiii

celiv

ib.

celvi

cclix

celxi

celxii

celxiy

celxvii

ib.

celxviii

celxx

cclxxii

celxxir

celxxvi

Offences 


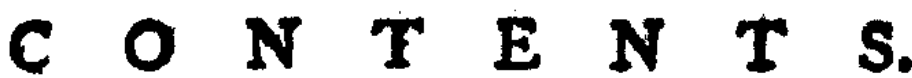

Offences touching the condition of a hurband - Page celxxviii Offences touching the condition of a wife - - c clxxx Civil conditions - - - celxxxir

8. Advantages of the prefent metbod.

General idea of the metbod here purfued ccxcr Its advantages - - cexcvi 1. - It is convenient for the apprebenfion and the memory - ib. -2. It gives room for general propofitions - $\quad-\quad$ cexcriii -3. Is points out the reafon of the law - - ccxeix -4. It is alike applicable to the laws of all nations - - cce

\section{Cbaracters of the five clafjes.}

Cberatiers of the claffes, how deducible from the above method

Charaders of clafs $\mathrm{I}$.

Characters of clafs 2.

Charaters of clafs 3.

Charaters of Clusf 4 .

Charaters of Clafs 5.

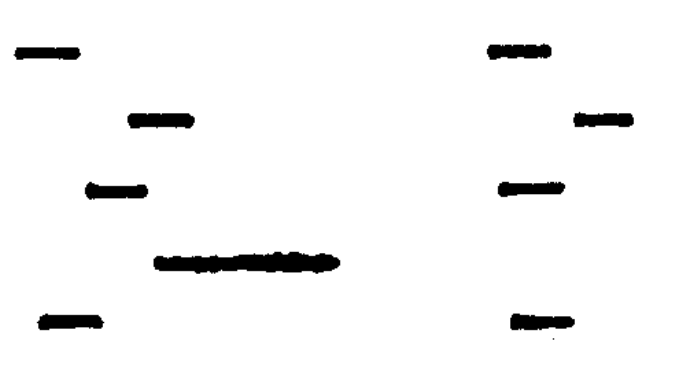

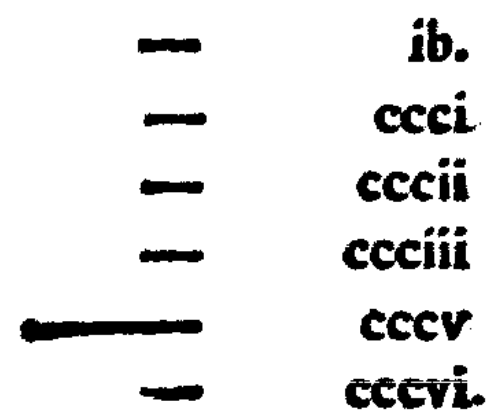

\section{Chap. XVII. Of the [Limits] of the penal branch of jurisprudence.}

\section{Limits between private etbics and tbe art of legilation.}

Dife of this chapter

Etbics in general, what

Private cthics
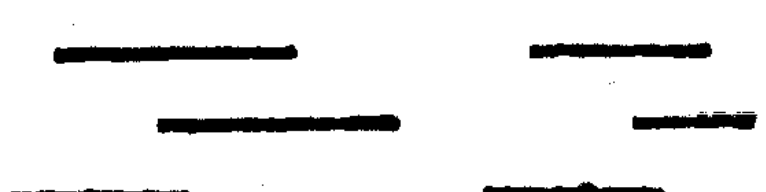

The art of gevernment : that is, of legiflation and adminifration Interefls of the infrier animals improperly negletted in legillation

Art of education

Ethics exhibits the rules of, 1. Prudence. 2. Probity. 3. Bengficence -

Probity and beneficence how they conneet with prudence

Every at which is a proper object of ethics is not of legillation

The limits between the provinces of private etbics and legiflation, marked out by the cafes unmeet for puniloment

a... -

Neither ought to apply where punilhment is groundlefs

2. How far private ethics can apply in the cales where punifhment would be ingficacious ccevii

cocriii

ib.

ib.

ib.

cccix $\operatorname{ccs} x$

ib.

cecxi

cccxii

ib.

ib.

How 


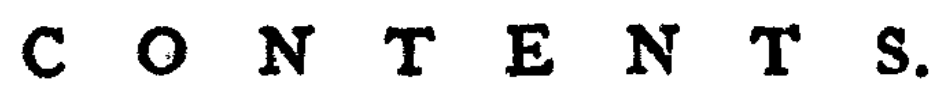

How far, where it would be unprofitable Page cecxiii

Which it may be, 1. Although confined to the guilty ccexiv

2. By enveloping the innocent - cecxis

Legifation how far neceffary for the enforcement of the dietates of pru-
dence

-Apt to go too far in this relpee

-Particularly in matters of religion _ - ib.

- How far neceflary for the enforcement of the dietates of probity - ccexix

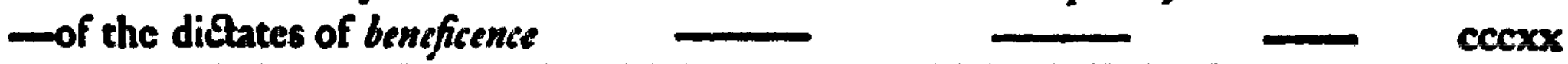

Difference between private ethics and the art of legination recapitulated - cccxxi

2. Jurifprudence, its brancbes.

Juriprudence, expefitery-cenforial

Expofitory jurifprudence, autboritative-unauthoritative $\quad$ ccexxii

Sources of the diftinAtions yet remaining _ _ _ _ ib.

Juriprudence, hal-univerfor - $\quad$ cccxxiii

-internal and international - ccexxiv

Internal jurifprudence, national and provincial, bocal or farticular _- cccxar

Jurifprudence, antient-living

Jurifprudence, fatutory-cuftomary -

Jurifprudence, civil-penal-criminal - ib.

Queftion, concerning the diftinction between the civil branch and the penal,

ftated

- $\quad$ - ccexxrii

Every law is either a command, or a revocation of one

A declaretery lase is not, properly fpeaking, a lass - $\quad$ - ib.

V. Every cocrcisec law creates an offence - - cecxxix

VL. A law creating an effence, and one appointing punifbment are diffind laws

VII. A differcrive law can have no punitory one appertaining to it but through the intervention of a coercive one

VIII. But a punitory law involves the fimply imperative one it belongs to -

1X. The fimply imperative one might therefore be fpared, but for its $2 x$.

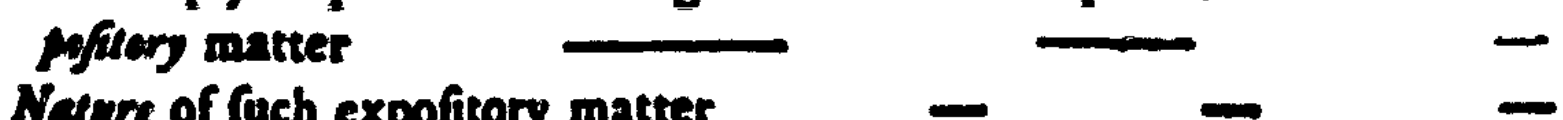

X. Narurc of fuch expofitory matter - -

XI. The vaftnefs of its comparative bulk is not peculiar to legiflative

Xi1. The fame mafe of expofitury matter may ferve in common for many laws

XI11. The impreatiec charater effential to law, is apt to be concealed in and by expefiers matter 


\section{$\begin{array}{lllllllll}C & O & N & T & E & N & T & S .\end{array}$}

XIV. The concealment is favoured by the multitude of indirea forms in which imperative matter is capable of being couched

Page cecxxxi

XV. Number and nature of the lawus in a code, how determined -

XVI. General idea of the limits between a civil and a penal code -

XVII. Contents of a civil code - $\quad$ - $\quad$ - $\quad$ - cecxxxii

XVIII. Contents of a peral code - _ - - ib.

XIX. In the Code Frederic the imperative charatter is almot loft in the ex-

XX. So in the Roman law - - - - -

XXI. In the barbarian codes it tands confpicuous - - - ib.

XXII. Conffientional code, its connexion with the two others - ib.

XXIII. Thus the matter of ome law may be divided among all tbree codes - cecxaxiii

XXIV. Expofitory matter a great quantity of it exilts every where, in no other form than that of rommon or judiciary law

ib.

XXV. Hence the deplorable Aate of the fcience of legillation, confidered in reípeê of its form

XXVI. Occafions affording an exemplifeation of the difieulty as well as importance of this branch of fcience ; -attempts to linit the powers of fupreme reprefentative legiflatures

ib.

XV1l. Brample: Amorices doclesetions of righso 
Publifbed by the fame Ausbor,

\section{A FRAGMENT on GOVERNMENT:}

Being an Examination of what is delivered on the fubject of Government in general, in the Introduction to Sir William Blackstone's ComMENTARIES :

With a Preface; in which is given a Critique on the Work at large.

\section{A VIEW of the HARD-LABOUR BILL:}

Being an Abrtract of a Pamphlet, intituled " Draught of a Bill, to punifh

" by Imprifonment and Hard-Labour, certain Offenders; and to efta-

" blith proper Offices for their Reception :"

Interfperfed with Obfervations relative to the fubject of the above Draught in particular, and to Penal Jurifprudence in general.

\section{DEFENCE of USURY :}

Shewing the Impolicy of the prefent legal Reftraints on the Terms of pecuniary Bargains.

In a Series of Letters to a Friend.

TO WHICH is $\triangle D D E D$,

A Letter to Adam Smith, Ese. L.L. D.

On the Difcouragements oppofed by the above Reftraints to the Progrefs of Inventive Induftry.

In the Prefs, Marcb 1789:

New Editions of the Fragment on Government, and the Defence of USURY. 
$\mathbf{A} \mathbf{N}$

\section{N T R O D U C T I O N}

T O T H B

\section{Principles of Morals and Legillation.}

\section{$\begin{array}{lllllll}\mathbf{P} & \mathbf{R} & \mathbf{E} & \mathbf{F} & \mathbf{A} & \mathbf{C} & \mathbf{E} \text {. }\end{array}$}

THE following foets were, as the title-page exprefes, printed fo long ago as in tbe year 1780. Tbe defign, in purfuance of wbicb they were written, was not fo extenfive as tbat announced by the prefent title. Tbey bad at tbat time no otber deftination tban tbat of ferving as an introduction 10 a plan of a penal code in terminis, defigned to follow them, in tbe fame volume.

Tbe body of tbe work bad reccived its completion according to the then prefent extent of tbe autbor's vieres, wobn, in the inveftigation of fome flaws be bad difccovered, be found bimfelf unexpetiedly entangled in an unsuspezted corner of tbe metapbyfical maxe. A fufpenfion, at firft not apprebended to be more tban a cemporary one, necelfarily enfued: Jufpenfion brougbt on coolnefs, and coolnefs, aided by otber concurrent caufes, ripened into difguft.

Imperfezions pervading tbe zobole mass bad already been pointed out by the fincerity of fevere and difcerning friends; and confcience bad certified tbe juftnefs of their cenfure. The incrdinate lengtb of fome of the chapters, the appaVol. I. 
rent inutitity of otbers, and the dry and metapbyfical turn of tbe wbole, fuggefsed an apprehinfion, that, if publifhed in its prcfent form, the work would contend under great difitivantages for any chance, it might on otber accounts fofiefs, of being racd, and comfequintly of being of ufe.

But, tkongig in this manner the idea of compleating the prefent work Jid infenfibly afsele, that wias not by any means the cafe with the confiderations wbicb basd lid bim to engage in it. Every opening, wbich promijed to afford the Iigbrs bic focd in need of, was ftill purfued: as occafion arofe, tbe feveral defartments cometted with that in wbich bo bad at firft engaged, zuerefuccelively aplered; inienuch that, in one brancb or otber of the purfuit, bis refearcbes lave nearly emibaced lbie atbole field of lezifation.

Secerai caufes bave conjpired at prefent to bring to ligbt, under tbis news title, a w:rk wbicb under its original one bad been imperceptibly, but as it bad festred irrecocauly, doomed so oblivion. In the courfe of eigbt years, materials for sarious works, correpponding 10 tbe different brancbes of tbe fubjeat of legiflation, bac been produced, and fome nearly reduced to faape: and, in every one if tbeje reorks, the prinsiples exbibited in tbe prefent publication bad been found fo seceffary, tbat, eitber to trailfcribe tbem piece-meal, or to exbibit tbem fomestivere wbere tbey could be referred to in the lump, was found unavoidable. The formcr courfe would bave occafioned repetitions too bulky to be employed witbout mecefity in tbe execution of a plan unavoidably fo voluminous: the latter was sberifore indijputably tbe preferable one.

To puilith tbe materials in tbe form in wbich they were already printed, or co sccrk them up into a new one, was therefore tbe only alternative: the latter bad all along been bis wifh, and, bad time and the requifite degree of alacrity ben at conmand, it would as certainly bave been realifed. Cogent confsderasin: bowceer, concur, seitb tbe irkfomenefs of the tafk, in placing tbe accompilithitus of it at prefent at an unfatbomable diftance.

Awct to itnfideration is, tbat tbe fuppreffion of tbe prefent sucrk, bad it been crer fo dxidedly soifbed, is no longer aitogetber in bis peseer. "In ibe courfe of fo leng an interval, various incidents bave introduced copies into various bands, from fane of subicb the bave been transferred, by deatbs and otber accidents, ints asbers that are unknoten to bim. Detacbed, but confsderable extraats, bave esen been publifbed, seitbout any difbonourable viesos, (for the name of tbe atubor swas very bonefly fubjoined to tbem) but woitbout bis privity, and in publications undertaken witbout bis knowledge. 


\section{$\begin{array}{lllllll}P & R & E & F & A & C & E\end{array}$}

It may perbaps be neceffary to add, to compleat bis excufe for offering to the public a work pervaded by blemifhes, wbich bave not efcaped even the autbor's partial eye, tbat the cenfure, fo jufly beftowed upon the form, did not extend isfelf to tbe matter.

In fending it tbus abroad into the world with all its imperfeetions upon its bead, be tbinks it may be of affiftance to the few readers be can expect, to receive a Jort intimation of the cbief particulars, in refpect of wbich it fails of correfponding witb bis maturer views. It will thence be otferved bow in fome refpets it fails of quadrating with the defign announced by its original title, as in otbers it does witb tbat announced by the one it bears at prefent.

An introdudion to a seork wbicb takes for its Jubject tbe totality of any fcience, ougbt to contain all fucb matters, and fucb matters only, as belong in common to every particular brancb of tbat fcience, or at leaft to more brancbes of it tban one. Compared witb its prefent title, tbe prefent work fails in botls ways of being conformable to that rule.

As an introduction to the principles of morals, in addition to the analyfis it contains of tbe extenfive ideas fignified by tbe terms pleafure, pain, motive, and difpofition, it ougbt to bave given a fimilar analyfis of the not lefs extenfive, tbougb mucb lefs determinate, ideas annexed to tbe terms emotion, paftion, appetite, virtue, vice, and fome otbers, including the names of the particular virtues and vices. But as the true, and, if be conceives rigbt, the only true ground-work for tbe developement of tbe latter fet of terms, bas been laid by the explamation of tbe former, the completion of fucb a diationary, fo to file it, soould, in comparijon of ibe commencement, be little more tban a mechanical operation.

Again, as an introduation to the principles of legination in general, it ougbt ratber to baze included matters belonging exclufively to the civil brancb, tban matters more particularly applicalle to the penal : the latter being but a means of compafing the euds propofed by the former. In preference tbereforc, or at leaft in pricrity, to the feveral chapters wobicb roill be found relative to pu. nifhment, it ought to bave exbibited a fet of propofitions wobicb beve fince prefented tbenfelves 10 bim as affording a frandard for the operations performed by government, in the creatioin and diftribution of proprictary and otber civil rigbts. Ile menns certain axioms of what may be terined mental pathology, exprefive of tbe commestion batstive the feetings of the parties concerned, and the 
feveral claffes of incidents, wibicb eitber call for, or are produced by, operations of the nature abosementioned .

The confsderation of the divifion of offences, and every tbing elfe tbat belongs so offences, ougbt, bifides, 10 bave preceded the confideration of punifbment: for the idea of punilhment prefuppojes the idea of offence: punifbment, as fuch, not being inficied but in confideration of offence.

Lafty, the analytical difcufions relative to the clafification of offences would, according to bis prefent views, be transferred to a feparale treatife, in wbicb tbe fysem of legiflation is confidered folely in refpeat of its form: in otber swords, in refpeat of its method and terminology.

In tbefe refpeats the performance fails of coming up to tbe autbor's oson ideas of what pould bave been exbibited in a work, bearing tbe title be bas noro given it, viz. that of an Introduction to the Principles of Morals and Legifation. He knows buwever of no otber tbat would be le/s unfuitable: nor in particular would so adequate an intimation of its attual contents bave been given, by a title correfponding to tbe more limited defign, witb wbicb it was written : viz. tbat of ferving as an introduction to a penal code.

Fet more. Dry and tedious as a great part of ibe difculfions it contains muft unavoidably be found by tbe bulk of readers, be knows not bow to regret tibe baving written tbell, nor even tbe baving made tbem public. Under every bead, tbe preatical ufes, to rebicb tbe difculfions contained under tbat bead appeared applicable, are indicated: nor is tbere, be believes, a fingle propofition sbat be bas not found occafion to build upon in the penning of fome article or olber of tbofe provifions of detail, of wbicb a body of law, autboritative or intautboritative, muft be compofed. He will venture to specify particularly, in ibis viest, tbe feveral cbapters Bortly cbaradierifed by the words Senfibility, Actions, Intentionality, Confcioufnels, Motives, Difpofitions, Confequences. Even in tbe enormous cbapter on tbe divifion of offences, wbicb, notscisiffanding tbe forced comprefion tbe plan bas undergone in feveral of its parts, in manner tbere mentioned, occupies no fesver tban one bundred and

- For example.-It is worfe 10 lofe tban fimply not 10 gain.-A lofs falls the ligbter by being divided. - Tbe fufferinge of a perjon burt in gratification of enmity, is greater tbas tbe gratification profuced by ibe fame canfe. Thefe, and a few others which he will have occaifion to exhibit at the head of anocher publication, have the fane clain to the appellation of axioms, as thofe given by mathematicians under that name ; fince, reforring to univerfal experience as their immediate bafis, they are incapable of demonitration, and require only to be developed and illutinted, in order to be recognized as inconceftible. 


\section{$\begin{array}{lllllll}P & R & E & F & A & C & E\end{array}$}

four of tbefe clofely printed quarto pages, the ten concluding ones are employed in a fratement of the practical advantages that may be reaped from tbe plait of clafification wbicb it exbibits. T'bofe in whofe figbt the Defence of Ufury bas been fortunate enough 10 find favour, may reckon as one inftance of tbofe advantages the difcovery of the principles developed in that little treatife. In tbe preface to an anonymous traet publifhed fo long ago as in 1776", be bad bimbed at tbe utility of a natural clafficication of offences, in tbe cbarabter of a te?? for difinguifbing genuine from fpurious ontes. The cafe of ufury is one ancong a number of inftances of the trutb of that obfervation. A note that may be found in page cck of tbe prefent publication, may ferve to ßeew boso tbe opinions, $d$ iveloped in tbat sratt, oceed tbeir origin to the difficulty experienced in tbe attempt to find a place in bis jyftem for that imaginary offence. To jome readers, as a means of belping tbem to fupport the fatigue of wading tbrougb an analy/s of fucb enormous lengtb, be would almoft reconmend the beginning woith thefe ten concluding pages.

One good at leaft may refult from the prefent publication; viz. that the mors be bas trefpaffed on tike patience of the reader on tbis occafion, the lefs need be will bave so to do on future ones: So that this may do to tbefe, the office sibicb is dome, in books of pure matbematics, 10 books of mixed matbematics and natural pbilofopby. The narrower the circle of readers is, witbin wbich the prefens work may be condemned to confine itfelf, the lefs limited may be tbe number of tbofe to wom the fruits of bis fucceeding labours may be found accefible. He may tberefore in tbis refped find bimfelf in the condition of thofe pbilofopbers of antiquity, subo are reprefented as baving beld two bodies of doetrine, a po. pular and an occult one: but, witb tbis difference, tbat in bis inftance the occult and tbe papular swill, be bopes, be found as confiflent as in tbofe they were contradiatory; and tbat in bis produltion whatever there is of occultnefs bas betit the pure refult of fad neceffity, and in no refpetz of cboice.

Having, in tbe courfe of tbis advertifement, bad fucb frequent occafion to allude to different arrangennents, as baving been Juggefted by more extenfive and maturer viecos, it may perbaps contribute to tbe fatisfaction of the reader, to receive a Jort intimation of tbeir nature: the ratber, as, witbout fucb explanation, references, made bere and tbere to unpublifbed works, might be productive of perplexity and miftake. The following tben are the titles of tbe works. by tbe publication of wbicb bis prefent defigns would be compleated. They are exbibited in sbe order wobicb Jeemed to bim beft fitted for apprebenfion, and in

- A Fragment on Goverament, \&cc. 
wbicb they would ftand difpofed, were the wbole affemblage ready to come out at once: but tbe order, in wbicb they will eventually appear, may probably enougb be infuenced in fome degree by collateral and temporary confiderations.

Part tbe $1 /$. Principles of legiflation in matters of civil, more diftinctively termed private diftributive, or for ßbortne/s, diftributive, law.

Part the $2 d$. Principles of legifation in matters of penal law.

Part tbe $3 d$. Principles of legiflation in matters of procedure: uniting in one view tbe criminal and civil brancbes, between wbicb no line can be drasen, but a very indiftinte one, and that continually liable to variation.

Part tbe 4 tb. Principles of legiflation in matters of reward.

Part ibe stb. Principles of legifation in matters of public diftributive, more concifely as well as familiarly termed conftitutional, law.

Part tbe 6tb. Principles of legilation in matters of political tactics: or of the art of maintaining order in tbe proceedings of political affemblies, fo as to diret? tbem 10 ibe end of tbeir inftitution: viz. by a fystem of rules, wobicb are to the confitutional brancb, in fome refpects, what the law of procedure is to the civil and tbe penal.

Part tbe 7 tb. Principles of legifation in matters betwixt nation and nation, or, 10 ufe a new tbougb not inexpreffive appellation, in watters of international lavo.

Part tbe 8tb. Principles of legiflation in matters of finance.

Part tbe $9 t b$. Principles of legiflation in matters of political economy.

Part tbe 10tb. Plan of a body of lass, compleat in all its brancbes, confidered in refpet of its form; in otber seords, in refpect of its metbod and terminology; including a vieso of the origination and connegtion of the ideas expreffed by tbe fbort lift of terms, the expofition of wbicb contains all tbat can be faid suitb propriety 10 beling to the bead of univerfal jurifprudence*.

The ufe of the principles laid down under the above feverai beads is to prepare tbe way for tbe body of law itfelf exbibited in terminis; and wbicb to be compleat, wisb reference to any political fate, muft confequeitily be calculated for tbe meridian, and adapted to tbe circumftances, of fome one fucb ftate in particular.

Had be an unlimited power of drawing upon time, and every otber condition neceffary, it would be bis siefb to poftpone tbe publication of each part to the

- Sach as obligation, right, power, poffeffion, title, exemption, immunity, franciife, privilege, aullity, validity, and the like. 


\section{$\begin{array}{lllllll}P & R & E & F & A & C & E .\end{array}$}

completion of the sobole. In particular, the ufe of the ten parts, subich exbibis wobat appear to bin tbe dictates of utility in every line, being no otber than to furnifs reafons for the feveral corresponding provifions contained in the tody of law itfelf, the exact trutb of the former can never be precifely afcertained, till tbe provifions, 10 wbicb tbey are deftined to appiy, are tbemfelves afiertained, and tbat in terminis. But as tbe infirmity of bumak nature renders all plans precarious in the execution, in proportion as they are extenfive in tbe defign, and as be bas already made confiderable advances in feveral branches of the tbeory, witbout baving made correfpendent advances in the practical applications, be deems it more iban proballt, tbat the eventual order of publication will not correfpond exadly with tbat wbich, bad it been equally prasticable, would bace appeared moft eligible. Of this irregularity the unavoidable refult will be, a muliitude of inperfections, wbich, if ibe execution of the body of law in terminis bad kept pace with the developement of ibe principles, fo that each part kad? been adjufted and correcied by tbe olber, might bave been avoided. His condust bowever will be the lefs fwayed ly tbis inconvenience, from bis Jufpecting it to be of the number of tbofe in sebicb the perforal vanity of the autbor is nucb wors concerned, tban tbe infruglion of the public: fince wbatever amendments moy $b^{\circ}$ fuggefted in tbe detail of the principles, by the litcral fixation of the provificis 10 wobicb ibey are relative, may eafily be made in a corrected edition of the former, fucceeding upon tbe publication of the latter.

In the courfe of the enfuing pages, references will be found, as already inti. mated, fome to the pian of a penal code to wibich this work was meant as an introdugion, fome to ctber trancbes of the abovementioned general plan, under titles fomewbat different from thoje, by wobicb they bave been mentioned bere. The giving this warning is all subich it is in the autbor's power to do, to fave the reader from the perplexity of looking out for what bas not as yet any cxifsence. The recolletion of the change of plan will in like manner account for feveral fimilar incongruities not wortb particularizing.

Tbe feet containing errata, with a few corrections and aduitions, is a copy of one wbicb was printed off a year or two after tbe work itfelf; and undergies at prefent no otber alteration tion that of its title: except in thofe paragrapts wobich are diffinguifred bis a recent date.

Allufion zeas made, at the culfet of this advertijemont, to fome unfpecified difficulties, as the canfes of the original fupperificn, and wirfinifsed complexion, of the prefont soork. Ahamed of bis defout, and unable to diffemble it, be knowis not 
boit to refufe bimfelf the benefit of fucb an apology as a figbt fketcb of the nasure of tbofe difficulties may afford.

The difcovery of them was produced by the attempt to folve the queftions tbat will be found at tbe conclufion of the volume: Wherein confifted the identity and compleatnefs of a law ? What the diftinction, and where the feparation, between a penal and a civil law ? What the diftinction, and where the feparation, between the penal and otber brancbes of tbe lase?

To give a compleat and correet anfwer to thefe queftions, it is but too evident that the relations and dependencies of every part of the legifative jystem, with refpect 10 every osber, muft bave been comprebended and afcertained. But it is only upon a view of thefe parts tbemfelves, that fucb an operation could bave been performed. To tbe accuracy of fucb a furvey one neceffary condition would tberefore be, the compleat exiftence of the fabric to be furveyed. Of the performance of tbis condition no example is as yet to be met with any where. Common law, as it ftiles itfelf in England, judiciary law, as it migbt more aptly be filed every wbere, that fietitious compofition wbicb bas no known perfon for its autbor, no known affemblage of words for its jubftance, forms every wbere the main body of tbe legal fabric: like tbat fancied atber, wbicb, in default of fenfible matter, fills up tbe meafure of the univerfe. Shreds and foratps of real law, ftuck on upon tbat imaginary ground, compose tbe furniture of every national code. Wbat follows? - tbat be wbo, for tbe purpofe juft mentioned or for any otber, wants an example of a compleat body of law to refer to, muft begin xitb making one.

Tbere is, or ratber tbere ougbt to be, a logic of tbe will, as well as of tbe underftanding: tbe operations of tbe former facully, are neitber less Jufceptible, nor lefs wortby, tban tbofe of tbe latter, of being delineated by rules. Of thefe troo brancbes of tbat recondite art, Ariffotle faw only the latter: Jucceeding logicians, treading in the fteps of tbeir great founder, bave concurred in Jeeing witb no otber eves. Yet fo far as a difference can be affigned between brancbes so intimately cometted, cobatever difference there is, in point of importance, is in farcar of tbe logic of tbe will. Since it is only by their capacity of directing sbe operations of tbis faculty, that the operations of tibe underftanding are of any corfortuchie.

Of ibis logic of tbe cuill, tbe fcience of law, confidered in refpett of its form, is the moft confiderable brancb, - tbe moft important application. It is, to tbs art of legiflation, sebat the fcience of analomy is 10 the art of medicine: witb 


\section{$\begin{array}{lllllll}P & R & E & F & A & C & E .\end{array}$}

tbis difference, tbat the fubjedt of it is what the artift bas to work with, infead of being wobat be bas to operate upon. Nor is the body politic less in danger from a want of acquaintance roilk tbe one fcience, tban the lody natural from ignorance in tbe otber. One example, among ft a tboufand tbat migbt be adduced in proof of tbis affertion, may be feen in tbe note wobich terminotes this volume.

Sucb tben were the difficulties: fucb the preliminaries:- an unexampled work to atcbieve, and tben a new fcience to create: a new branch to add to one of the moft abftrufe of fciences.

Yet more: $A$ body of propofed law, bow compleat foever, would be comparatively ufelefs and uninfruelive, unless explained and jufified, and that in every tittle, by a continued accompaniment, a perpetual commentary of reafons: wbicb reafons, tbat tbe comparative value of Jucb as point in oppofite direstions may be eftimated, and tbe conjinat force, of fucb as point in the faine direction, may be felt, muft be marßsalled, and put under fubordination to fucb extenfive and leading ones as are termed principles. There muft be therefore, not one fyfens only, but two parallel and connelted Jystems, running on togetber, tbe one of legifative provifions, tbe otber of political reafons, eacb affording to tbe other correation and fupport.

Are enterprizes like tbefe atcbievalle? He knows not. This only be knoses, tbat the barec been undertaken, proceeded in, and tbat fome progress bas been made in all of tbem. He soill venture to add, if at all atcbievable, never at leaft by one, to wobsen tbe fatigue of attending to difculions, as arid as tbofe wobicb occupy tbe enfuing pages, would eitber appcar ufeless, or feel intolerable. He will repeat it boldly (for it bas been faid before bim,) trutbs tbat form sbe bafis of political and moral fcience, are not to be difcovered but by invefigations as fevere as matbematical ones, and beyond all comparifon more intricate and extenfive. The familiarity of the terms is a prefumption, but it is a moff fallacious one, of the facility of the matter. Trutbs in general bace been salled fubborn tbings: the trutbs juft mentioned are fo in tbeir own way. They are not to be forced into detacbed and general propofitions, unincumbered soilb explanations and exceptions. They suill not compress themfelves into epigrams. They recoil from the tongue and the pen of tbe declaimer. Tbey flourifs not in tbe fame foil witb fentiment. They grow among tborns; and are not to be plucked, like daifies, by infants as they run. Labour, the inevitable lot of bumanity, is in no track more inevitable than bere. In vain would an Alexander befpeak a peculiar road for royal vanity, or a Ptolemy, a jmotber one, for royal indolence. There is no King's Road, no Stadthoider's Gate, to legifative, any more than 16 malbematic fcience. 


\title{
$\begin{array}{lllllllllllll}I & N & T & R & O & D & \text { U } & \text { G } & \text { T } & \text { I } & \text { O } & \text { N }\end{array}$ \\ TO THE
}

\section{Principles of Morals and Legiflation.}

\author{
I N T R O D U C T ION. \\ C H A P. I.
}

NATURE has placed mankind under the governance of two fovereign mafters, pain and pleafure. It is for them alone to point out what we ought to do, as well as to determine what we thall do. On the one hand the ftandard of right and wrong, on the other the chain of caufes and effects, are faftened to their throne. They govern us in all we do, in all we fay, in all we think : every effort we can

INTROD. Chap. I. Mankind governed by pain and pleafure. make to throw off our fubjection, will ferve but to demonftrate and confirm it. In words a man may pretend to abjure their empire : but in reality he will remain fubject to it all the while. The prinsiple of utility recognizes this fubjection, and affumes it for the foundation of that fyftem, the object of which is to rear the fabric of felicity by the hands of reafon and of law. Syftems which attempt to queftion it, deal in founds inftead of fenfe, in caprice inftead of reafon, in darknefs inftead of light.

But enough of metaphor and declamation: it is not by fuch means that moral fcience is to be improved.

Vol. I. 
INTROD.

ChAP. I.

Principle of utility, what.
II.

The principle of utility is the foundation of the prefent work: it will be proper therefore at the outfet to give an explicit and determinate account of what is meant by it. By the principle ${ }^{-a}$ of utility is meant that principle which approves or difapproves of every action whatfoever, according to the tendency which it appears to have to augment or diminifh the happinefs of the party whofe intereft is in queftion: or, what is the fame thing in other words, to promote or to oppofe that happinefs. I fay of every action whatfoever; and therefore not only of every action of a private individual, but of every meafure of government.

\section{III.}

Utility, what.

By utility is meant that property in any object, whereby it tends to produce benefit, advantage, pleafure, good, or happinefs (all this in the prefent cafe comes to the fame thing) or (what comes again to the fame thing) to prevent the happening of mifchief, pain, evil, or unhappinefs to the party whofe intereft is confidered: if that party be the community in general, then the happinefs of the community: if a particular individual, then the happinefs of that individual.

\section{IV.}

Intereft of the community, what.

The intereft of the community is one of the moft general expreffions that can occur in the phrafeology of morals : no wonder that the meaning of it is often loft. When it has a meaning, it is this. The community is a fictitious body, compofed of the individual perfons who

[ Principle] The word principle is derived from the Latin principium : which feems to be compounded of the two words primus, firft, or chief, and cipium, a termination which feems to be derived from capio to take, as in mancipium, municipium; to which are analogus auceps, forceps, and othors. It is a term of very vague and very extenfive fignification: it is applied to any thing which is conceived to ferve as a foundation or beginning to any feries of operations: in fome cafes, of phyfical operations; but of mental operations in the prefent cafe.

The principle here in queftion may be taken for an aot of the mind; a fentiment; a fentiment of approbation; a fentiment which, when applied to an action, approves of its utility, as that quality of it by which the meafure of approbation or difapprobation beflowed upon it ought to be governed. 
are confidered as conftituting as it were its members. The intereft of INTROD. the community then is, what? the fum of the interefts of the feveral Crap.I. members who compofe it.

$\mathrm{V}$.

It is in vain to talk of the intereft of the community, without underftanding what is the intereft of the individual ${ }^{\circ}$. A thing is faid to promote the intereft, or to be for the intereft, of an individual, when it tends to add to the fum total of his pleafures: or, what comes to the fame thing, to diminifh the fum total of his pains.

VI.

An action then may be faid to be conformable to the principle of utility, or, for fhortnefs fake, to utility, (meaning with refpect to the community at large) when the tendency it has to augment the happinefs of the community is greater than any it has to diminifh it.

VII.

A meafure of government (which is but a particular kind of action, performed by a particular perfon or perfons) may be faid to be conformable to or dictated by the principle of utility, when in like manner the tendency which it has to augment the happinefs of the community is greater than any which it has to diminifh it.

VIII.

When an action, or in particular a meafure of government, is fuppofed by a man to be conformable to the principle of utility, it may be convenient, for the purpofes of difcourfe, to imagine a kind of law or dictate, called a law or dictate of utility: and to fpeak of the action in queftion, as being conformable to fuch law or dictate.

IX.

A man may be faid to be a partizan of the principle of utility, when the approbation or difapprobation he annexes to any action, or to any meafure, is determined by and proportioned to the tendency which he A partizan of the princi. ple of utility, conceives it to have to augment or to diminifh the happinefs of the government conformable to the principle of utility, what. ple of utility, what.

Laws or

dictates of utility, what.

[ Intereft, \&cc.] Intereft is one of thofe words, which not having any fuperior genus, Intereft a fic。 cannot in the ordinary way be defined.

titious entity. 
INTROD. CHAP. I.

Ought, ought not, right and wrong, \&cc. how to be underftood.

To prove the rectitude of this principle is at once unneceffary and impoffible.

It has feldom, however, as yet, been confiftently purfued. community: or in other words, to its conformity or unconformity to. the laws or dictates of utility.

$\mathrm{X}$.

Of an action that is conformable to the principle of utility, one may always fay either that it is one that ought to be done, or at leaft that it is not one that ought not to be done. One may fay alfo, that it is right it hould be done; at leaft that it is not wrong it fhould be done : that it is a right action; at leaft that it is not a wrong action. When thus interpreted, the words ought, and right and wrong, and others of that ftamp, have a meaning: when otherwife, they have none.

$\mathrm{XI}$.

Has the rectitude of this principle been ever formally contefted? It fhould feem that it had, by thofe who have not known what they have been meaning. Is it fufceptible of any direct proof? it hould feem not: for that which is ufed to prove every thing elfe, cannot itfelf be proved: a chain of proofs muft have their commencement fomewhere. To give fuch proof is as impoffible as it is needlefs.

$\mathrm{XII}$.

Not that there is or ever has been that human creature breathing, however ftupid or perverfe, who has not on many, perhaps on moft occafions of his life, deferr'd to it. By the natural conftitution of the human frame, on moft occafions of their lives men in general embrace this principle, without thinking of it: if not for the ordering of their own actions, yet for the trying of their own actions, as well as of thofe of other men. There have been, at the fame time, not many, perhaps, even of the mort intelligent, who have been difpofed to embrace it purely and without referve. There are even few who have not taken fome occafion or other to quarrel with it, either on account of their not underftanding always how to apply it, or on account of fome prejudice or other which they were afraid to examine into, or could not bear to part with. For fuch is the ftuff that man is made of : in principle and in practice, in a right track and in a wrong one, the rareft of all human qualities is confiftency. 


\section{Of the Principle of [U T I L I T Y.]}

XIII.

INTROD,

When a man attempts to combat the principle of utility, it is with reafons drawn, without his being aware of it, from that very principle itfelf. "His arguments, if they prove any thing, prove, not that the principle is wrong; but that, according to the applications he fuppofes to be made of it, it is mifapplied. Is it poffible for a man to move the earth? Yes; but he muft firft find out another earth to ftand upon.

\section{XIV:}

To difprove the propriety of it by arguments is imporfible; but, from the caufes that have been mentioned, or from fome confufed or partial view of it, a man may happen to be difpofed not to relin it. Where this is the cafe, if he thinks the fettling of his opinions on fuch a fubject worth the trouble, let him take the following fteps, and at length, perhaps, he may come to reconcile himfelf to it.

I. Let him fettle with himfelf, whether he would with to difcard this principle altogether; if fo, let him confider what it is that all his reafonings (in matters of politics efpecially) can amount to ?

2. If he would, let him fettle with himfelf, whether he would judge and act without any principle, or whether there is any other he would judge and act by?

3. If there be, let him examine and fatisfy himfelf whether the principle he thinks he has found is really any feparate intelligible principle; or whether it be not a mere principle in words, a kind of phrafe, which at bottom expreffes neither more nor lefs than the mere averment of his own unfounded fentiments; that is, what in another perfon he might be apt to call caprice?

4. If he is inclined to think that his own approbation or difapprobation, annexed to the idea of an act, without any regard to its confequences, is a fufficient foundation for him to judge and act upon, let

" "The principle of utility," (I have heard it faid) " is a dangerous principle: it "is dangerous on certain occafions to confult it." This is as much as to fay, what? that it is not confonant to utility, to confult utility: in thort, that it is not confulting it to confult it.

Courfe to be taken for furmounting prejudices that may have been entertained againlt it. 
INTROD. him afk himfelf whether his fentiment is to be a ftandard of right and Crap. I. wrong, with refpect to every other man, or whether every man's fentiment has the fame privilege of being a ftandard to itfelf?

5. In the firft cafe, let him ank himfelf whether his principle is not defpotical, and hoftile to all the relt of human race?

6. In the fecond cafe, whether it is not anarchical, and whether at this rate there are not as many different ftandards of right and wrong as there are men? and whether even to the fame man, the fame thing, which is right to-day, may not (without the leaft change in its nature) be wrong to-morrow? and whether the fame thing is not right and wrong in the fame place at the fame time? and in either cafe, whether all argument is not at an end? and whether, when two men have faid, "I " like this," and "I don't like it," they can (upon fuch a principle) have any thing more to fay?

7. If he Mould have faid to himfelf, No: for that the fentiment which he propofes as a ftandard muft be grounded on reflection, let him fay on what particulars the reflection is to turn? if on particulars having relation to the utility of the act, then let him fay whether this is not deferting his own principle, and borrowing affiftance from that very one in oppofition to which he fets it up: or if not on thofe particulars, on what other particulars?

8. If he hould be for compounding the matter, and adopting his own principle in part, and the principle of utility in part, let him fay how far he will adopt it?

9. When he has fettled with himfelf where he will ftop, then let him ank himfelf how he juftifies to himfelf the adopting it fo far? and why he will not adopt it any farther?

ro. Admitting any other principle than the principle of utility to be a right principle, a principle that it is right for a man to purfue; admitting (what is not true) that the word right can have a meaning without reference to utility, let him fay whether there is any fuch thing as a motive that a man can have to purfue the dictates of it: if there is, let him fay what that motive is, and how it is to be diftinguifhed from thofe which enforce the dictates of utility: if not, then laftly let him fay what it is this other principle can be good for?

C H A P. 
C H A P. II.

I.

F the principle of utility be a right principle to be governed by, and that in all cafes, it follows from what has been juft obferved, that whatever principle differs from it in any cafe muft neceffarily be a wrong one. To prove any other principle, therefore, to be a wrong one, there needs no more than juft to thew it to be what it is, a principle of which the dictates are in fome point or other different from thofe of the INTROD: CHAP. II. All other principles than that of utility muft principle of utility: to ftate it is to confute it.

II.

A principle may be different from that of utility in two ways: I. By being conftantly oppofed to it: this is the cafe with a principle which may be termed the principle of afceticis ${ }^{2}$. 2. By being fometimes opbe wrong. pofed to it, and fometimes not, as it may happen: this is the cafe with another, which may be termed the principle of fympatby and antipatby.

[a Afceticilm] Afcetic is a term that has been fometimes applied to Monks. It comes from a Greek word which fignifies exercife. The practices by which Monks fought to diftinguifh themfelves from other men, were called their exercifes. Thefe exercifes confifted in fo many contrivances they had for tormenting themfelves. By this they thought to ingratiate themfelves with the Deity. For the Deity, faid they, is a Being of infinite benevolence: now a Being of the moft ordinary benevolence is pleafed to fee others make themfelves as happy as they can: therefore to make ourfelves as unhappy as we can is the way to pleafe the Deity. If any body afked them, what motive they could find for doing all this? Oh! faid they, you are not to imagine that we are punifhing ourfelves for nothing: we know very well what we are about. You are to know, that for every grain of pain it colts us now, we are to have a hundred grains of pleafure by and by. The cafe is, that God loves to fee us torment ourfelves at prefent : indeed he has as good as told us fo. But this is done only to try us, in order juft to fee how we thould behave: which it is plain he could not know, without making the experiment. Now then, from the fatisfaction it gives him to fee us make ourfelves as unhappy as we can make ourfelves. in this prefent life, we have a fure proof of the fatisfaction it will give him to fee us as happy as he can make us in a life to come.

Ways in which a principle may be wrong.
Afceticifm; origin of the word. Prineiples of the Monks.

III. By 
INTROD

CHAP. II.

Principle of sfceticifm,

what. of the principle of afceticifm, who.

This principle has had in fome $a$ philofophical, in others 2 religious origin.
III.

By the principle of afceticifm I mean that principle, which, like the principle of utility, approves or difapproves of any action, according to the tendency which it appears to have to augment or diminin the happinefs of the party whofe intereft is in queftion; but in an inverfe manner: approving of actions in as far as they tend to diminifh his happinefs; difapproving of them in as far as they tend to augment it.

IV.

It is evident that any one who reprobates any the leaft particle of pleafure, as fuch, from whatever fource derived, is pro tanto a partizan of the principle of afceticifm. It is only upon that principle, and not from the principle of utility, that the moft abominable pleafure which the vileft of malefactors ever reaped from his crime would be to be reprobated, if it ftood alone. The cafe is, that it never does ftand alone; but is neceffarily followed by fuch a quantity of pain (or, what comes to the fame thing, fuch a chance for a certain quantity of pain) that the pleafure in comparifon of it, is as nothing: and this is the true and fole, but perfectly fufficient, reafon for making it a ground for punifhment.

$\mathrm{V}$.

There are two claffes of men of very different complexions, by whom the principle of afceticifm appears to have been embraced; the one a fet of moralifts : the other a fet of religionifts. Different accordingly have been the motives which appear to have recommended it to the notice of thefe different parties. Hope, that is the profpect of pleafure, feems to have animated the former: hope, the aliment of philofophic pride: the hope of honour and reputation at the hands of men. Fear, that is the profpect of pain, the latter: fear, the offspring of fuperftitious fancy: the fear of future punifhment at the hands of a fplenetic and revengeful Deity. I lay in this cafe fear: for of the invifible future, fear is more powerful than hope. Thefe circumftances characterize the two different parties among the partizans of the principle of afceticifm; the parties and their motives different, the principle the fame. 
The religious party, however, appear to have carried it farther than the philofophical: they have acted more confiftently and lefs wifely. The philofophical party have frarcely gone farther than to reprobate pleafure : the religious party have frequently gone fo far as to make it a matter of merit and of duty to court pain. The philofophical party have hardly gone farther than the making pain a matter of indifference. ChaP.II. It has been carried farther by the religious party than by the philofophical. It is no evil, they have faid: they have not faid, it is a good. They have not fo much as reprobated all pleafure in the lump. They have difcarded only what they have called the grofs; that is, fuch as are organical, or of which the origin is eafily traced up to fuch as are organical : they have even cherifhed and magnified the refined. Yet this, however, not under the name of pleafure: to cleanfe itfelf from the fordes of its impure original, it was neceffary it hould change its name : the honourable, the glorious, the reputable, the becoming, the boneftum, the decorum, it was to be called: in fhort, any thing but pleafure.

VII.

From thefe two fources have flowed the doctrines from which the The philofentiments of the bulk of mankind have all along received a tincture of fophical this principle; fome from the philofophical, fome from branch of it fome from both. Men of education more frequently from the philofo- infuence phical, as more fuited to the elevation of their fentiments : the vulgar fons of edumore frequently from the fuperftitious, as more fuited to the narrownefs cation, the of their intelleet undilated by knowledge: and to the abjetnefs of religious their condition, continually open to the attacks of fear. The tinets of vulgar. however, derived from the two fources, would naturally interning, however, derived from the two fources, would naturally intermingle, infomuch that a man would not always know by which of them he was moft influenced: and they would often ferve to corroborate and enliven one another. It was this conformity that made a kind of alliance between parties of a complexion otherwife fo diffimilar: and difpofed them to unite upon various occafions againft the common enemy, the partizan of the principle of utility, whom they joined in branding with the odious name of Epicurean.

VoL. I.

VIII. The 
INTROD. Chap. II.

The principle of afceticirm has never been fteadily applied by either party to the bufinefs of government.

\section{VIII.}

The principle of afceticifm, however, with whatever warmth it may have been embraced by its partizans as a rule of private conduct, feems not to have been carried to any confiderable length, when applied to the bufinefs of government. In a few inftances it has been carried a little way by the philofophical party: witners the Spartan regimen. Though then, perhaps, it may be confidered as having been a meafure of fecurity : and an application, though a precipitate and perverfe application, of the principle of utility. Scarcely in any inftances, to any confiderable length, by the religious: for the various monattic orders, and the focieties of the Quakers, Dumplers, Moravians, and other religionifts, have been free focieties, whofe regimen no man has been aftrikted to without the intervention of his own confent. Whatever merit a man may have thought there would be in making himfelf miferable, no fuch notion feems ever to have occurred to any of them; that it may be a merit, much lefs a duty, to make others miferable: although it fhould feem, that if a certain quantity of mifery were a thing fo defirable, it would not matter much whether it were brought by each man upon himfelf, or by one man upon another. It is true, that from the fame fource from whence, among the religionifts, the attachment to the principle of afceticifm took its rife, flowed other doctrines and practices, from which mifery in abundance was produced in one man by the inftrumentality of another: witnefs the holy wars, and the perfecutions for religion. But the paffion for producing mifery in thefe cafes proceeded upon fome fpecial ground: the exercife of it was confined to perfons of particular defcriptions: they were tormented, not as men, but as heretics and infidels. To have inflicted the fame miferies on their fellow-believers and fellow-fectaries, would have been as blameable in the eyes even of thefe religionifts, as in thofe of a partizan of the principle of utility. For a man to give himfelf a certain number of ftripes was indeed meritorious: but to give the fame number of ftripes to another man, not confenting, would have been a fin. We read of faints, who for the good of their fouls, and the mortification of their bodies, have voluntarily yielded themfelves a prey to vermin: 
but though many perfons of this clafs have wielded the reins of INTROD. empire, we read of none who have fet themfelves to work, and made laws on purpofe, with a view of ftocking the body politic with the breed of highwaymen, houfebreakers, or incendiaries. If at any time they have fuffered the nation to be preyed upon by fwarms of idle penfioners, or ufelefs placemen, it has rather been from negligence and imbecillity, than from any fettled plan for oppreffing and plundering of the people. If at any time they have fapped the fources of national wealth, by cramping commerce, and driving the inhabitants into emigration, it has been with other views, and in purfuit of other ends. If they have declaimed againtt the purfuit of pleafure, and the ufe of wealth, they have commonly ftopt at declamation: they have not, like Lycurgus, made exprefs ordinances for the purpofe of banifhing the precious metals. If they have eftablifhed idlenefs by a law, it has been not becaufe idlenefs, the mother of vice and mifery, is itfelf a virtue, but becaufe idlenefs (fay they) is the road to holinefs. If under the notion of fafting, they have joined in the plan of confining their fubjects to a diet, thought by fome to be of the moft nourifhing and prolific nature, it has been not for the fake of making them tributaries to the nations by whom that diet was to be fupplied, but for the fake of manifefting their own power, and exercifing the obedience of the people. If they have eftablifhed, or fuffered to be eftablinhed, punifhments for the breach of celibacy, they have done no more than comply with the petitions of thofe deluded rigorifts, who, dupes to the ambitious and deep-laid policy of their rulers, firtt laid themfelves under that idle obligation by a vow.

\section{IX.}

The principle of afceticifm feems originally to have been the reverie The princiof certain hafty fpeculators, who having perceived, or fancied, that cer- ple of afcetitain pleafures, when reaped in certain circumftances, have, at the long cifm, in its run, been attended with pains more than equivalent to them, took oc- but that of cafion to quarrel with every thing that offered itfelf under the name of atility mifpleafure. Having then got thus far, and having forgot the point which they fet out from, they puthed on, and went fo much further as to

$$
\text { C } 2 \text { think }
$$


INTROD. think it meritorious to fall in love with pain. Even this, we fee, is at Char. II. bottom but the principle of utility mifapplied.

$\mathrm{X}$.

It can never The principle of utility is capable of being confiftently purfued; and ly purfued.
it is but tautology to fay, that the more confiftently it is purfued, the better it muft ever be for human-kind. The principle of afceticifm never was, nor ever can be, confiftently purfued by any living creature. Let but one tenth part of the inhabitants of this earth purfue it confiftently, and in a day's time they will have turned it into a hell.

$\mathrm{XI}$.

The princi- Among principles adverfe to that of utility, that which at this day ple of fym- feems to have moft influence in matters of government, is what may antipathy, be called the principle of fympathy and antipathy. By the principle of what. - fympathy and antipathy, I mean that principle which approves or difapproves of certain actions, not on account of their tending to augment the happinefs, nor yet on account of their tending to diminilh thehappinefs of the party whofe intereft is in queftion, but merely becaufe a man finds himfelf difpofed to approve or difapprove of them: holding up that approbation or difapprobation as a fufficient reafon for itfelf, and difclaiming the neceffity of looking out for any extrinfic ground. Thus far in the general department of morals : and in the particular department of politics, meafuring out the quantum (as well as determining the ground) of punifhment, by the degree of the difapprobation.

XII.

This is ra- It is manifeft, that this is rather a principle in name than in reality: it ther the ne- is not a pofitive principle of itfelf, fo much as a term employed to figgation of all
principle, nify the negation of all principle. What one expects to find in a prinmeans of warranting and guiding the internal fentiments of approbation and difapprobation: this expectation is but ill fulfilled by a propofition, which does neither more nor lefs than hold up each of thofe fentiments as a ground and ftandard for itfelf. 
In looking over the catalogue of human actions (fays a partizan of this principle) in order to determine which of them are to be marked with the feal of difapprobation, you need but to take counfel of your own feelings: whatever you find in yourielf a propenfity to condemn, is wrong for that very reafon. For the fame reafon it is alfo meet for punifhment : in what proportion it is adverfe to utility, or whether it be adverfe to utility at all, is a matter that makes no difference. In that fame proportion alfo is it meet for punifhment: if you hate much, punih much: if you hate little, punin little: punith as you hate If you hate not at all, punith not at all : the fine feelings of the foul are not to be overborne and tyrannized by the har $\mathrm{h}$ and rugged dictates of political utility.

\section{XIV.}

The various fyftems that have been formed concerning the ftandard of right and wrong, may all be reduced to the principle of fympathy and antipathy. One account may ferve for all of them. They confift all of them in fo many contrivances for avoiding the obligation of appealing to any external ftandard, and for prevailing upon the reader to accept of the author's fentiment or opinion as a reafon for itfelf. The phrafes different, but the principle the fame ${ }^{b}$.

b It is curious enough to obferve the variety of inventions men have hit upon, and Various phrafes, the variety of phrafes they have brought forward, in order to conceal from the world, that have ferved and, if poffible, from themfelves, this very general and therefore very pardonable felf- iftic marks of fufficiency.

The fyftems that have been formed concerning. the ftandard of right and wrong, are all reducible to this principle.

1. One man fays, he has a thing made on purpofe to tell him what is right and what $x$. Moral Senfe. is wrong; and that it is called a moral fenfe : and then he goes to work at his eafe, and fays; fuch a thing is right, and fuch a thing is wrong-why? " becaufe my moral "fenfe tells me it is."

2. Another man comes and alters the phrafe: leaving out moral, and putting in 2. Common common, in the room of it. He then tells you, that his common fenfe teaches him what is right and wrong, as furely as the other's moral fenfe did : meaning by common fenfe, a fenfe of fome kind or other, which, he fays, is poffeffed by all mankind: the fenfe of thofe, whofe fenfe is not the fame as the author's, being ftruck out of the account as not worth taking. This contrivance does better than the other; for a moral 
xiv

INTROD. Chap. II.

This principle will frequently coincide with that of utility.

3. Underftand ing.

4. Rule of Right.

5. Fitnels of Thinge.

6. Law of $\mathrm{Na}$. ture.

7. Liw of Rea 7. LiN of Rea Reafon, Natural Reafon, Natural Equity, Good Order.

\section{of [PRINCIPLES ADVERSE] to that of Utility.}

$\mathrm{XV}$.

It is manifert, that the dictates of this principle will frequently coincide with thofe of utility, though perhaps without intending any fuch thing. Probably more frequently than not: and hence it is that

the

renfe, being a new thing, a man may feel about him a good while without being able to find it out: but common fenfe is as old as the creation; and there is no man but would be afhamed to be thought not to have as much of it as his neighbours. It has another great advantage : by appearing to thare power, it leffens envy: for when a man gets up upon this ground, in order to anathematize thofe who differ from him, it is not by a fic volo fic jubeo, but by a velitis jubeatis.

3. Another man comes, and fays, that as to a moral fenfe indeed, he cannot find that he has any fuch thing: that however he has an underftanding, which will do quite as well. This underttanding, he fays, is the ftandard of right and wrong: it tells him fo and fo. All good and wife men underttand as he does: if other men's underftandings differ in any point from his, fo much the worfe for them : it is a fure fign they are either defeetive or corrupt.

4. Another man fays, that there is an eternal and immutable Rule of Right: that that rule of right dictates fo and fo: and then he begins giving you his fentiments upon any thing that comes uppermoft: and thefe fentiments (you are to take for granted) are fo many branches of the eternal rule of right.

5. Another man, or perhaps the fame man (it's no matter) fays, that there are certain practices conformable, and others repugnant, to the Fitnefs of Things; and then he tells you, at his leifure, what practices are conformable and what repugnant: juft as he happens to like a practice or dillike it.

6. A great multitude of people are continually talking of the Law of Nature ; and then they go on giving you their fentiments about what is right and what is wrong: and thefe fentiments, you are to underftand, are fo many chapters and fections of the Law of Nature.

7. Inftead of the phrafe, Law of Nature, you have fometimes, Law of Reafon, Right Reafon, Natural Juftice, Natural Equity, Good Order. Any of them will do equally well. This latter is moft ufed in politics. The three laft are much more tolerable than the others, becaufe they do not very explicitly claim to be any thing more than phrafes : they infift but feebly upon the being looked upon as fo many politive ftandards of themfelves, and feem content to be taken, upon occafion, for phrafes expreffive of the conformity of the thing in queftion to the proper ftandard, whatever that may be. On moft occafions, however, it will be better to fay utility: utility is clearer, as referring more explicitly to pain and pleafure.

8. We have one philofopher, who fays, there is no harm in any thing in the world but in telling a lie : and that if, for example, you were to murder your own father, 


\section{Of [PRINCIPLES ADVERSE] to that of Utility.}

the bufinefs of penal juftice is carried on upon that tolerable fort of INTROD. footing upon which we fee it carried on in common at this day. For $\mathrm{C}_{H A P}$. II.

what

this would only be a particular way of faying, he was not your father. Of conrfe, when this philofopher fees any thing that he does not like, he fays, it is a particular way of telling a lie. It is faying, that the act ought to be done, or may be done, when, in truth, it ought not to be done.

9. The faireft and openeft of them all is that fort of man who fpeaks out, and fays, 9. Donine os. I am of the number of the Elect: now God himfelf takes care to inform the Eleat what is right: and that with fo good effeet, that let them ftrive ever fo, they cannot help not only knowing it but practifing it. If therefore a man wants to know what is right and what is wrong, he has nothing to do but to come to me.

It is upon the principle of antipathy that fuch and fuch acts are often reprobated on Repugnancy to the fcore of their being unnatural: the practice of expofing children, eftablithed among the Greeks and Romans, was an unnatural practice. Unnatural, when it means any thing, means unfrequent: and there it means fomething; although nothing to the prefent purpofe. But here it means no fuch thing: for the frequency of fuch acts is perhaps the great complaint. It therefore means nothing; nothing, I mean, which there is in the act itfelf. All it can ferve to exprefs is, the difpofition of the perfon who is talking of it : the difpofition he is in to be angry at the thoughts of it. Does it merit his anger ? Very likely it may: but whether it does or no is a queftion, which, to be anfwered rightly, can only be anfwered upon the principle of utility.

Unnatural, is as good a word as moral fenfe, or common fenfe; and would be as good a foundation for a fyftem. Such an act is unnatural; that is, repugnant to nature: for $\mathrm{I}$ do not like to practife it; and, confequently, do not practife it. It is therefore sepugnant to what ought to be the nature of every body elfe.

The mifchief common to all thefe ways of thinking and arguing (which, in truth, Mifchief they as we have feen, are but one and the fame method, couched in different forms of produce. words) is their ferving as a cloak, and pretence, and aliment, to defpotifm : if not a defpotifm in practice, a defpotifm however in difpofition: which is but too apt, when pretence and power offers, to thew itfelf in practice. The confequence is, that with intentions very commonly of the pureft kind, a man becomes a torment either to himfelf or his fellow-creatures. If he be of the melancholy caft, he fits in filent grief, bewailing their blindnefs and depravity: if of the irafcible, he declaims with fury and virulence againft all who differ from him; blowing up the coals of fanaticifm, and branding with the charge of corruption and infincerity, every man who does not think, or profefs to think, as he does.

If fuch a man happens to poffers the advantages of ftile, his book may do a confi. derable deal of mifchief before the nothingnefs of it is undertood.

Thefe principles, if fuch they can be called, it is more frequent to fee applied to morals than to politics: but their infuence extends itfelf to both. In politics, as 
INTROD. what more natural or more general ground of hatred to a practice can Chap. II. there be, than the mifchievoufnefs of fuch practice? What all men

well as morals, a man will be at leaft equally glad of a pretence for deciding any queftion in the manner that beft pleafes him, without the trouble of enquiry. If a man is an infallible judge of what is right and wrong in the actions of private individuals, why not in the meafures to be obferved by public men in the direction of fuch actions of thore individuals? accordingly (not to mention other chimæras) I have more than once known the pretended law of nature fet up in legillative debates, in oppofition to arguments derived from the principle of utility.

"B But is it never, then, from any other confiderations than thofe of atility, that we

Whether utility is actually the all the aporoba tion.we ever befow, is a different confideration.

" derive our notions of right and wrong?" I do not know : I do not care. Whether a moral fentiment can be originally conceived from any other fource than a view of utility, is one queltion: whether upon examination and reflection it can, in point of fact, be actually perfifted in and juftified on any other ground, by a perfon reflecting within himfelf, is another: whether in point of right it can properly be juftified on any other ground, by a perion addreffing himfelf to the community, is a third. The two firft are queftions of fpeculation: it matters not, comparatively fpeaking, how they are decided. The laft is a queftion of practice : the decifion of it is of as much importance as that of any can be.

"I feel in myfelf," fay you, " a difpofition to approve of fuch or fuch an action in " a moral view: but this is not owing to any notions $I$ have of its being a ufeful one " to the community. I don't pretend to know whether it be an ufeful one or not: " it may be, for aught I know, a mifchievous one." "But is it then," fay I, " a "mifchievous one? examine; and if you can make yourfelf fenfible that it is fo, " then, if duty means any thing, that is, moral duty, it is your duty" at leaft to ab.

" ftain from it: and more than that, if it is what lies in your power, and can be done

"s without too great a facrifice, to endeavour to prevent it. It is not your cherifhing

" the notion of it in your bofom, and giving it the name of virtue, that will excufe

"you."

"I feel in myfelf," fay you again, "a difpofition to deteft fuch or fuch an action

"in a moral yiew; but this is not owing to any notions $I$ have of its being a mif-

" chievous one to the community. I do not pretend to know whether it be a mif-

" chievous one or not: it may be not a mifchievous one: it may be, for aught I

"know, an ufeful one."-" May it indeed," fay I, " an ufeful one $?$ but let me tell

" you then, that unlefs duty, and right and wrong, be juft what you pleafe to make

" them, if it really be not a mifchievous one, and any body has a mind to do it, it

" is no duty of your's, but, on the contrary, it would be very wrong in you, to take

" upon you to prevent him : deteft it within yourfelf as much as you pleafe; that may

" be a very good reafon (unlefs it be alfo a ufeful one) for your not doing it your- 
are expofed to fuffer by, all men will be difpofed to hate. It is far yet, however, from being a conftant ground: for when a man fuffers, it is INT ROD. not always that he knows what it is he fuffers by. A man may fufier grievouny, for inftance, by a new tax, without being able to trace up the caufe of his fufferings to the injuftice of fome neighbour, who has eluded the payment of an old one.

XVI.

The principle of fympathy and antipathy is moft apt to err on the fide of feverity. It is for applying punifhment in many cafes which deferve none: in many cafes which deferve fome, it is for applying more than they deferve. There is no incident imaginable, be it ever fo trivial, and fo remote from mifchief, from which this principle may not extract a ground of punifhment. Any difference in tafte: any difference in opinion: upon one fubject as well as upon another. No difagreement fo triffing which perfeverance and altercation will not render ferious. Each becomes in the other's eyes an enemy, and, if laws permit, a criminalc. This is one of the circumftances by which

the

" felf: but if you go about, by word or deed, to do any thing to hinder him, or " make him fuffer for it, it is you, and not he, that have done wrong: it is not your " fetting yourfelf to blame his conduet, or branding it with the name of vice, that " will make him culpable, or you blamelers. Therefore, if you can make yourfelf " content that he fhall be of one mind, and you of another, about that matter, and " fo continue, it is well : but if nothing will ferve you, but that you and he muft " needs be of the fame mind, I'll tell you what you have to do: it is for you to get " the better of your antipathy, not for him to truckle to it."

- King James the Firft of England had conceived a violent antipathy againft Arians: two of whom he burnt *. This gratification he procured himfelf without much difficulty: the notions of the times were favourable to it. Ne wrote a furicus book againft Vortius, for being what was called an Arminian: for Vorftius was at a diftance. He alfo wrote a furious book, called A Counterbaft to Tobacco, againt the ufe of that drug, which Sir Walter Raleigh had then lately introduced. Had the notions of the times co-operated with him, he would have burnt the Anabaptif and the fmoker of tobacco in the fame fire. However he had the fatisfaction of putting Raleigh to death afterwards; though for another crime.

Difputes concerning the comparative excellence of French and Italian mufic have 
INTROD. the human race is diftinguifhed (not much indeed to its advantage) CHAP. II. from the brute creation.

\section{XVII.}

But errs, in fome inftances, on the fide of lenity.

- See cha xvi. [Divifion] par. 42, 44.

It is not, however, by any means unexampled for this principle to err on the fide of lenity. A near and perceptible mifchief moves antipathy. A remote and imperceptible mifchief, though not lefs real, has no effeet. Inftances in proof of this will occur in numbers in the courfe of the work *. It would be breaking in upon the order of it to give them here.

\section{XVIII.}

The theological principle, whatnot a feparate principle.

It may be wondered, perhaps, that in all this while no mention has been made of the tbeological principle; meaning that principle which profeffes to recur for the ftandard of right and wrong to the will of God. But the cafe is, this is not in fact a diftinct principle. It is never any thing more or lefs than one or other of the three beforementioned principles prefenting itfelf under another hape. The will of God here meant cannot be his revealed will, as contained in the facred writings: for that is a fyftem which nobody ever thinks of recurring to at this time of day, for the details of political adminiftration: and even before it can be applied to the details of private conduct, it is univerfally allowed, by the moft eminent divines of all perfuafions, to ftand in need of pretty ample interpretations; elfe to what ufe are the works of thofe divines? And for the guidance of thefe interpretations, occafioned very ferious bickerings at Paris. One of the parties would not have been is Mufigue. tences were fought after and urged. Long before that, a difpute of like nature, and of at leaft equal warmth, had been kindled at London upon the comparative merits of two compofers at London; where riots between the approvers and difapprovers of a new play are, at this day, not unfrequent. The ground of quarrel between the Big-en. dians and the Little-endians in the fable, was not more frivolous than many an one which has laid empires defolate. In Ruflia, it is faid, there was a time when fome thoufands of perfons loft their lives in a quarrel, in which the government had taken part, about the number of fingers to be ufed in making the fign of the crofs. This was in days of yore : the minifters of Catherine II. are better infructed + than to take any other part in fuch difputes, than that of preventing the parties concerned from doing one another a mifchief. 
it is alfo allowed, that fome other ftandard muft be affumed. The will then which is meant on this occafion, is that which may be called the prefumptive will : that is to fay, that which is prefumed to be his will on account of the conformity of its diftates to thofe of fome other principle. What then may be this other principle? it muft be one or other of the three mentioned above: for there cannot, as we have feen, be any more. It is plain, therefore, that, fetting revelation out of the queftion, no light can ever be thrown upon the ftandard of right and wrong, by any thing that can be faid upon the queftion, what is God's will. We may be perfectly fure, indeed, that whatever is right is conformable to the will of God: but fo far is that from anfwering the purpofe of thewing us what is right, that it is neceffary to know firft whether a thing is right, in order to know from thence whether it be conformable to the will of God ${ }^{\text {. }}$.

\section{XIX.}

There are two things which are very apt to be confounded, but which it imports us carefully to diftinguin :- the motive or caufe, which, by operating in a man's mind, is productive of any act: and the ground or reafon which warrants a leginator, or other by-ftander, in regarding

- The principle of theology refers every thing to God's pleafure. But what is God's pleafure? God does not, he confeffedly does not now, either fpeak or write to us. How then are we to know what is his pleafure? By obferving what is our own pleafure, and pronouncing it to be his. Accordingly, what is called the pleafure of God, is and muft neceffarily be (revelation apart) neither more nor lefs than the good pleafure of the perfon, whoever he be, who is pronouncing what he believes, or pretends to be, God's pleafure. How know you it to be God's pleafure that fuch or fuch an act thould be abtained from? whence come you even to fuppofe as much ? " Becaufe the engaging in it would, I imagine, be prejudicial upon the whole to the " happinefs of mankind;" fays the partizan of the principle of utility: "Becaufe " the commiffion of it is attended with a grofs and fenfual, or at leat with a trifling " and tranfient fatisfaction;" fays the partizan of the principle of afceticifm : "Be" caufe I deteft the thoughts of it; and I cannot, neither ought I to be called upon to " tell why;" fays he who proceeds upon the principle of antipathy. In the words of one or other of thefe mult that perfon neceffarily anfwer (revelation apart) who profeffes to take for his ftandard the will of God.

Antipathy, let the actions it dictates be ever fo right, is never of itnever of itground of action.

The principle of theology how reducible to one principles. 
INTROD. that act with an eye of approbation. When the act happens, in the Crap. II. particular inftance in queftion, to be productive of effects which we approve of, much more if we happen to obferve that the fame motive may frequently be productive, in other inftances, of the like effects, we are apt to transfer our approbation to the motive itfelf, and to affume, as the juft ground for the approbation we beftow on the act, the circumitance of its originating from that motive. It is in this way that the fentiment of antipathy has often been confidered as a juft ground of action. Antipathy, for inftance, in fuch or fuch a cafe, is the caufe of an action which is attended with good effects: but this does not make it a right ground of action in that cafe, any more than in any other. Still farther. Not only the effects are good, but the agent fees beforehand that they will be fo. This may make the action indeed a perfectly right action: but it does not make antipathy a right ground of action. For the fame fentiment of antipathy, if implicitly deferred to, may be, and very frequently is, productive of the very worft effects. Antipathy, therefore, can never be a right ground of action. No more, therefore, can refentment, which, as will be feen more particularly hereafter, is but a modification of antipathy. The only right ground of action, that can pofibly fubfift, is, after all, the confideration of utility, which, if it is a right principle of action, and of approbation, in any one cafe, is fo in every other. Other principles in abundance, that is, other motives, may be the reafons why fuch and fuch an act bas been done: that is, the reafons or caufes of its being done: but it is this alone that can be the reafon why it might or ought to have been done. Antipathy or refentment requires always to be regulated, to prevent its doing mifchief: to be regulated by what? always by the principle of utility. The principle of utility neither requires nor admits of any other regulator than itfelf. 


\section{II A P. III.}

I.

$\mathrm{T}$ has been thewn that the happinefs of the individuals, of whom a community is compofed, that is their pleafures and their fecurity, is the end and the fole end which the leginator ought to have in view: the fole ftandard, in conformity to which each individual ought, as far as depends upon the leginator, to be made to fafhion his behaviour. Eut whether it be this or any thing elfe that is to be done, there is nothing by which a man can ultimately be made to do it, but either pain or pleafure. Having taken a general view of thefe two grand objects (viz. pleafure, and what comes to the fame thing, immunity from pain) in the character of final caufes; it will be neceffary to take a view of pleafure and pain itfelf, in the character of efficient caufes or means.

II. Four fanc-

There are four diftinguifhable fources from which pleafure and pain are in ufe to flow: confidered feparately, they may be termed the phy-

INTROD. CHAP. III.

Connedtion of this chap. ter with the preceding.

a Sanctio, in Latin, was ufed to fignify the aft of binding, and, by a common grammatical tranfition, any tbing rubich ferves to bind a man: to wit, to the obfervance of fuch or fuch a mode of conduct. According to a Latin grammarian *, the import of servius. See the word is derived by rather a far-fetched procefs (fuch as thofe commonly are, and in Ainfworth's a great meafure indeed mult be, by which intellectual ideas are derived from fenfible Santio. ones) from the word fanguis, blood: becaufe, among the Romans, with a view to inculcate into the people a perfuafion that fuch or fuch a mode of conduct would be rendered obligatory upon a man by the force of what I call the religious fanction (that is, that he would be made to fuffer by the extraordinary interpofition of fome fuperior being, if he failed to obferve the mode of conduct in queftion) certain ceremonies were contrived by the priefts $:$ in the courfe of which ceremonies the blood of victims was made ufe of.

A Sanction then is a fource of obligatory powers or motives: that is, of pains and pleafures; which, according as they are connected with fuch or fuch modes of conduct, operate, and are indeed the only things which can operate, as motives. See Chap.x. [Motives.] 
INTROD. fical, the political, the moral, and the religious: and inafinuch as the Crap. III. pleafures and pains belonging to each of them are capable of giving a binding force to any law or rule of conduct, they may all of them be termed fanctions.

III.

1. The phyfi- If it be in the prefent life, and from the ordinary courfe of nature, not purpofely modified by the interpofition of the will of any human being, nor by any extraordinary interpofition of any fuperior invifible being, that the pleafure or the pain takes place or is expected, it may be faid to iffue from or to belong to the pbyfical fanction.

IV.

2. The po- If at the hands of a particular perfon or fet of perfons in the community, who under names correfpondent to that of judge, are chofen for the particular purpore of difpenfing it, according to the will of the fovereign or fupreme ruling power in the ftate, it may be faid to iffue from the political Sanction.

$\mathrm{V}$. 3. The If at the hands of fuch cbance perfons in the community, as the party
moral. in queftion may happen in the courfe of his life to have concerns with, according to each man's fpontaneous difpofition, and not according to any fettled or concerted rule, it may be faid to iffue from the moral fanction.

VI.

4. The re- If from the immediate hand of a fuperior invifible being, either in ligious. the prefent life, or in a future, it may be faid to iffue from the religious fanction.

VII.

The plea- Pleafures or pains which may be expected to iffue from the phyfical, pains which political, or moral fanctions, muft all of them be expected to be expebelong to the rienced, if ever, in the prefent life: thofe which may be expected to fanction, may iffue from the religious fanction, may be expected to be experienced regard either the prefent either in the present life or in a future.

life or a

fusure.

VIII. Thore 
Thofe which can be experienced in the prefent life, can of courfe be no others than fuch as human nature in the courfe of the prefent life is fufceptible of: and from each of thefe fources may flow all the pleafures or pains of which, in the courfe of the prefent life, human nature is fufceptible. With regard to thefe then (with which alone we have in this place any concern) thofe of them which belong to any one of thofe fanctions, differ not ultimately in kind from thofe which belong to any one of the other three : the only difference there is among them duction. lies in the circumitances that accompany their production. A fuffering which befalls a man in the natural and fpontaneous courfe of things, thall be ftiled, for inftance, a calamity; in which cafe, if it be fuppofed to befall him through any imprudence of his, it may be ftiled a puninment iffuing from the phyfical fanction. Now this fame fuffering, if inflicted by the law, will be what is commonly called a punifsment; if incurred for want of any friendly affiftance, which the mifconduct, or fuppofed mifconduct, of the fufferer has occafioned to be withholden, a punifhment iffuing from the moral fanction; if through the immediate interpofition of a particular providence, a punifhment iffuing from the religious fanction.

\section{IX.}

A man's goods, or his perfon, are confumed by fire. If this hap- Example. pened to him by what is called an accident, it was a calamity: if by reafon of his own imprudence (for inftance, from his neglecting to put his candle out) it may be ftiled a punifhment of the phyfical fanction: if it happened to him by the fentence of the political magiftrate, a punifhment belonging to the political fanction; that is, what is commonly called a punifhment: if for want of any affiftance which his neigbbour withheld from him out of fome dillike to his moral character, a punimment of the moral fanction: if by an immediate act of God's difpleafure, manifefted on account of fome fin committed by him, or through any diftraction of mind, occafioned by the dread of fuch difpleafure, a punifhment of the religious fanction ${ }^{b}$.

\section{As} b A fuffering conceived to befall a man by the immediate act of God, as above, is A Judgmento
often, what, 
xxiv

INTROD.

CHAP. III:

Thofe which regard a furure iife

are not fpecifically

known.

\section{Of the four [SANCTIONS] or Sources of Pain and Pleafure.}

$\mathrm{X}$.

As to fuch of the pleafures and pains belonging to the religious fanction, as regard a future life, of what kind thefe may be we cannot know. Thefe lie not open to our obfervation. During the prefent life they are matter only of expectation: and, whether that expectation be derived from natural or revealed religion, the particular kind of pleafure or pain, if it be different from all thofe which lie open to our obfervation, is what we can have no idea of. The beft ideas we can obtain of fuch pains and pleafures are altogether unliquidated in point of quality. In what other refpects our ideas of them may be liquidated will be confidered in another place ${ }^{c}$.

\section{$\mathrm{XI}$.}

The phyfical fanction in cluded in each of the other three.

Of thefe four fantions the phyfical is altogether, we may obferve, the ground-work of the political and the moral: fo is it alfo of the religious, in as far as the latter bears relation to the prefent life. It is included in each of thofe other three. This may operate in any cafe, (that is, any of the pains or pleafures belonging to it may operate) independently of them: none of them can operate but by means of this. In a word, the powers of nature may operate of themfelves; but neither the magiftrate, nor men at large, can operate, nor is God in the cafe in queftion fupposed to operate, but through the powers of nature.

\section{XII.}

Ufe of this chapter. mon, it feemed of ufe to find a common name. It feemed of ufe, in the firft place, for the convenience of giving a name to certain pleafures and pains, for which a name equally characteriftic could hardly otherwife have been found: in the fecond place, for the fake of holding up the efficacy of certain moral forces, the influence of which is apt not to be fufficiently attended to. Does the political fancion exert an influence over the conduct of mankind? The moral, the religious fanc-

often, for thortnefs fake, called a judgment : inftead of faying, a fuffering inflicted on him in confequence of a fpecial judgment formed, and refolution thereupon taken, by the Deity.

s See ch, xiii. [Cafes unmeet] par. 2. Note. 
tions do fo to. In every inch of his career are the operations of the political magiftrate liable to be aided or impeded by thefe two foreign powers : who, one or other of them, or both, are fure to be either his rivals or his allies. Does it happen to him to leave them out in his calculations? he will be fure almoft to find himfelf miftaken in the refult. Of all this we thall find abundant proofs in the fequel of this work. It behoves him, therefore, to have them continually before his eyes; and that under fuch a name as exhibits the relation they bear to his own purpofes and defigns.

Vol. I, 


\section{C $\mathrm{H}$ A P. IV.}

I.

INTROD. DLEASURES then, and the avoidance of pains, are the ends which Chap. IV. 1 the leginator has in view: it behoves him therefore to underftand Ufe of this their value. Pleafures and pains are the inftruments he has to work chapter. with: it behoves him therefore to underftand their force, which is again, in other words, their value.

II.

Circumftances to be taken in to the account in eftimating the value of a pleafure or pain confidered with reference to a fingle perfon, and by itfelf.

-confidered as connected with other pleafures or pains.

To a perfon confidered by bimfelf, the value of a pleafure or pain confidered by itfelf, will be greater or lefs, according to the four following circumftances:

1. Its intenfity.

2. Its duration.

3. Its certainty or uncertainty.

4. Its proximity or remotene/s.

\section{III.}

Thefe are the circumftances which are to be confidered in eftimating a pleafure or a pain confidered each of them by itfelf. But when the value of any pleafure or pain is confidered for the purpofe of eftimating the tendency of any act by which it is produced, there are two other circumftances to be taken into the account; thefe are,

5. Its fecundity, or the chance it has of being followed by fenfations of the fame kind: that is, pleafures, if it be a pleafure: pains, if it be a pain.

6. Its purity, or the chance it has of not being followed by fenfations. of the oppofite kind: that is, pains, if it be a pleafure : pleafures, if it be a pain.

Thefe two laft, however, are in ftrictnefs fcarcely to be deemed properties of the pleafure or the pain itfelf; they are not, therefore, in ftrictnefs to be taken into the account of the value of that pleafure or that pain. They are in ftrictnefs to be deemed properties only of the 
[VALUE] of a Lot of Pleafure or Pain bow to be meafured.

act, or other event, by which fuch pleafure or pain has been produced; and accordingly are only to be taken into the account of the tendency of fuch act or fuch event.

IV.

To a number of perfons, with reference to each of whom the value of a pleafure or a pain is confidered, it will be greater or lefs, according to feven circumftances: to wit, the fix preceding ones; viz.

I. Its intenfity:

2. Its duration.

3. Its certainty or uncertainty.

4. Its proximity or remoteness.

5. Its fecundity.

6. Its purity.

And one other; to wit :

7. Its extent; that is, the number of perfons to whom it extends; or (in other words) who are affected by it.

V.

To: take an exact account then of the general tendency of any act, Procefs for by which the interefts of a community are affected, proceed as follows. Begin with any one perfon of thofe whofe interefts feem moft immediately to be affected by it: and take an'account,

1. Of the value of each diftinguifhable pleafure which appears to be produced by it in the firft inftance.

2. Of the value of each pain which appears to be produced by it in the firft inftance.

3. Of the value of each pleafure which appears to be produced by it after the firft. This conftitutes the fecundity of the firft pleafure, and the impurity of the firft pain.

4. Of the value of each pain which appears to be produced by it after the firft. This conftitutes the fecundity of the firft pain, and the impurity of the firft pleafure.

5. Sum up all the values of all the pleafures on one fide, and thore of all the pains on the other. The balance, if it be on the fide of pleafure, will give the good tendency of the act upon the whole, with re- 
xxviii [VALUE] of a Lot of Pleafiure ar Pain bow to be meafured.

INTROD. Spect to the interefts of that individual perfon; if on the fide of pain, CHap. IV. the bad tendency of it upon the whole.

6. Take an account of the number of perfons whofe interefts appear to be concerned; and repeat the above procefs with refpect to each. Sum up the numbers expreffive of the degrees of good tendency which the act has, with refpect to each individual, in regard to whom the tendency of it is good upon the whole : do this again with refpect to. each individual, in regard to whom the tendency of it is bad upon the whole. Take the balance; which, if on the fide of pleafure, will give the general good tendency of the act, with refpect to the total number or commannity of individuals concerned: if on the fide of pain, the general evil tendency, with refpect to the fame community.

VI.

Ufe of the foregoing procefs.

It is not to be expected that this procefs hould be ftrictly purfued previounly to every moral judgment, or to every leginative or judicial operation. It may, however, be always kept in view : and as near as. the procefs actually purfued on thofe occafions approaches to it, fo near will fuch procefs approach to the character of an exact one.

VII.

The fame process. ap plicable to good and cvil, profit and mifchief and all other modifications of pleafure and pain.

The fame procefs is alike applicable to pleafure and pain, in whatever thape they appear, and by whatever denomination they are diftinguifhed: to pleafure, whether it be called good (which is properly the caufe or inftrument of pleafure) or profit (which is diftant pleafure, or the caufe or inftrument of diftant pleafure) or convenience, advantage, benefit, emolument, bappiness, and fo forth : to pain, whether it be called evil (which correfponds to good) or mifcbief, or inconvenience, or difadvantage, or lofs, or unbappinefs, and fo forth.

VIII.

Conformity of men's practice to this theory.

Nor is this a novel and unwarranted, any more than it is a ufelefs. theory. In all this there is nothing but what the practice of mankind, wherefoever they have a clear view of their own intereft, is perfectly conformable to. An article of property, an eftate in land, for inftance, is valuable, on what account? On account of the pleafures of all kinds which it enables a man to produce, and, what comes to the fame thing; 
the pains of all kinds which it enables him to avert. But the value of INTROD. fuch an article of property is univerfally underftood to rife or fall ac- C cording to the length or fhortnefs of the time which a man has in it: the certainty or uncertainty of its coming into poffeffion : and the nearnefs or remotenefs of the time at which, if at all, it is to come into poffeffion. As to the intenfity of the pleafures which a man may derive from it, this is never thought of, becaufe it depends upon the ufe which each particular perfon may come to make of it; which cannot be eftimated till the particular pleafures he may come to derive from it, or the particular pains he may come to exclude by means of it, are brought to view. For the fame reafon, neither does he think of the fecundity or purity of thofe pleafures.

Thus much for pleafure and pain, happiners and unhappiners, in general. We come now to confider the feveral particular kinds of pain and pleafure. 
C $\quad \mathrm{H} \quad \ddot{A}$ P. V.

I.

INTROD. H AVING reprefented what belongs to all forts of pleafures and Chap.V. 1 pains alike, we come now to exhibit, each by itfelf, the feveral Pleafures and forts of pains and pleafures. Pains and pleafures may be called by one
pains are either. 1. Simple : or, 2. Complex. general word, interefting perceptions. Interefting perceptions are either fimple or complex. The fimple ones are thofe which cannot any one of them be refolved into more: complex are thofe which are refolvable into divers fimple ones. A complex interefting perception may accordingly be compofed either, i. Of pleafures alone: 2. Of pains alone: or, 3. Of a pleafure or pleafures, and a pain or pains together. What determines a lot of pleafure, for example, to be regarded as one complex pleafure, rather than as divers fimple ones, is the nature of the exciting caufe. Whatever pleafures are excited all at once by the action of the fame caufe, are apt to be looked upon as conftituting all together but one pleafure.

II.

The fimple pleafures
enumerated.

The feveral fimple pleafures of which human nature is fufceptible, feem to be as follows: I. The pleafures of fenfe. 2. The pleafures of wealth. 3. The pleafures of ikill. 4. The pleafures of amity. 5. The pleafures of a good name. 6. The pleafures of power. 7. The pleafures of piery. 8. The pleafures of benevolence. 9. The pleafures of malevolence. 10. The pleafures of memory. 11. The pleafures of the imagination. 12. The pleafures of expectation. 13. The pleafures dependent on affociation. 14. The pleafures of relief.

III.

The fimple pains enu.

The feveral fimple pains feem to be as follows: r. The pains of merated. privation. 2. The pains of the fenfes. 3. The pains of awkwardnefs. 4. The pains of enmity. 5. The pains of an ill name. 6. The pains of piety. 7. The pains of benevolence. 8 . The pains of malevolence. 
9. The pains of the memory. I0. The pains of the imagination. II. The pains of expectation:

IV.

INTROD. Chap. V.

1. The pleafures of fenfe feem to be as follows: 1. The pleafures of the tafte or palate; including whaterer pleafures are experienced in fatisfying the appetites of hunger and thirft. 2. The pleafures of the organ of fmelling. 3. The pleafures of the touch. 4. The fimple pleafures of the ear; independent of affociation. 5. The fimple pleafures of the eye; independent of affociation. 6. The pleafure of the venereal fenfe. 7. The pleafure of health: or, the internal pleafurable feeling or How of fpirits (as it is called) which accompanies a ftate of full health and vigour; efpecially at times of moderate bodily. exertion. 8. The pleafures of novelty : or, the pleafures derived from the gratification of the appetite of curiofity, by the application of new objects to any of the fenfes.

V.

2. By the pleafures of wealth may be meant thofe pleafures which a man is apt to derive from the confcioufnefs of poffeffing any article or articles which ftand in the lift of inftruments of enjoyment or fecurity, and more particularly at the time of his firft acquiring them; at which time the pleafure may be ftiled a pleafure of gain or a pleafure of Pleafures of fenfe enumerated. acquifition: at other times a pleafure of poffeffion.

3. The pleafures of ikill, as exercifed upon particular objects, are thofe which accompany the application of fuch particular inftruments of enjoyment to their ufes, as cannot be fo applied without a greater or lefs thare of difficulty or exertion ${ }^{b}$.

VI. 4.

2 The catalogue here given, is what feemed to be a compleat lift of the feveral fimple plearures and pains of which human nature is fufceptible: infomuch, that if, upon any occafion whatfoever, a man feels pleafure or pain, it is either referable at once to fome one or other of thefe kinds, or refolvable into fuch as are. It might perhaps have been a fatisfaction to the reader, to have feen an analytical view of the fubject, taken upon an exhautive plan, for the purpofe of demonftrating the catalogue to be what it purports to be, a compleat one. 'The catalogue is in fact the refult of fuch an analyfis; which, however, $I$ thought it better to difcard at prefent, as being of too metaphyfical a calt, and not ftrictly within the limits of this defign. See ch. xiii. [Cafes unmect] Par. 2. Note.

D For inftance, the pleafure of being able to gratify the fenfe of hearing, by fing.

Pleafures: wealth, which are either of acquifition, or of poffeftion.

3. Pleafures of Akill. 
xxxii

INTROD.

Chap. V.

4. Pleafures

of amity.

of a good

name.

* See ch, iii. [Sanctions.]

6. Pleafures of power.

Tsee ch. iii,
[Sanctione.]

\section{[PLEASURES AND PAINS] tbeir Kinds.}

VI.

4. The pleafures of amity, or felf-recommendation, are the pleafures that may accompany the perfuafion of a man's being in the acquifition or the poffeffion of the good-will of fuch or fuch affignable perfon or perfons in particular: or, as the phrafe is, of being upon'good terms with him or them: and as a fruit of it, of his being in a way to have the benefit of their fpontaneous and gratuitous fervices.

VII.

5. The pleafures of a good name are the pleafures that accompany the perfuafion of a man's being in the acquifition or the pofferfion of the good-will of the world about him; that is, of fuch members of fociety as he is likely to have concerns with; and as a means of it, either their love or their efteem, or both : and as a fruit of it, of his being in the way to have the benefit of their fpontaneous and gratuitous fervices. Thefe may likewife be called the pleafures of good repute, the pleafures of honour, or the pleafures of the moral fanction *.

VIII.

6. The pleafures of power are the pleafures that accompany the perfuafion of a man's being in a condition to difpofe people, by means of their hopes and fears, to give him the benefit of their fervices: that is, by the hope of fome fervice, or by the fear of fome differvice, that he may be in the way to render them.

IX.

7. Pleafures 7. The pleafures of piety are the pleafures that accompany the belief of piety. of a man's being in the acquifition or in poffeffion of the good-will or favour of the Supreme Being: and as a fruit of it, of his being in a way of enjoying pleafures to be received by God's efpecial appointment, either in this life, or in a life to come. Thefe may alfo be called the pleafures of religion, the pleafures of a religious difpolition, or the pleaiures of the religious fanction $t$.

ing, or performing upon any mufical inftrument. The pleafure thus obtained, is a thing fuperadded to, and perfectly diftinguifhable from, that which a man enjoys from hearing another perfon perform in the fame manner. 
8. The pleafures of benevolence are the pleafures refulting from the view of any pleafures fuppofed to be poffeffed by the beings who may be the objects of benevolence; to wit, the fenfitive beings we are acPleafures of benevoquainted with; under which are commonly included, $\mathbf{r}$. The Supreme ence or good-will. Being. 2. Human beings. 3. Other animals. Thefe may alfo be called the pleafures of good-will, the pleafures of fympathy, or the pleafures of the benevolent or focial affections.

XI.

9. The pleafures of malevolence are the pleafures refulting from the view of any pain fuppofed to be fuffered by the beings who may become the objects of malevolence: to wit, I. Human beings. 2. Other 9. Pleafures of malevolence or illanimals. Thefe may alfo be ftiled the pleafures of ill-will, the pleafures of the irafcible appetite, the pleafures of antipathy, or the pleafures of the malevolent or diffocial affections.

\section{XII.}

10. The pleafures of the memory are the pleafures which; after having enjoyed fuch and fuch pleafures, or even in fome cafe after having fuffered fuch and fuch pains, a man will now and then experience, at recollecting them exactly in the order and in the circumftances in which they were actually enjoyed or fuffered. Thefe derivative pleafures may of courfe be diftinguifhed into as many fpecies as there are of original perceptions, from whence they may be copied. They may alfo be ftiled pleafures of fimple recollection.

\section{XIII.}

II. The pleafures of the imagination are the pleafures which may be derived from the contemplation of any fuch pleafures as may happen to be fuggefted by the memory, but in a different order, and accompanied by different groupes of circumftances. Thefe may accordingly be referred to any one of the three cardinal points of time, prefent, paft, or future. It is evident they may admit of as many diftinctions as thofe of the former clafs.

XIV.

12. The pleafures of expectation are the pleafures that refult from the contemplation of any fort of pleafure, referred to time future, and

Vor. I.

10: Pleafures of the memory:

11. Pleafures of the imagination. 
INTROD. accompanied with the fentiment of belief. Thefe alfo may admit of CHAP. V. the fame diftinctions.

13. Pleafures afociation. depending on

$\mathrm{XV}$.

13. The pleafures of affociation are the pleafures which certain objects or incidents may happen to afford, not of themfelves, but merely in virtue of fome affociation they have contracted in the mind with certain objects or incidents which are in themfelves pleafurable. Such is the cafe, for iniftance, with the pleafure of $\mathrm{nkill}$, when afforded by fuch a fet of incidents as compofe a game of chefs. This derives its pleafurable quality from its affociation partly with the pleafures of fkill, as exercifed in the production of incidents pleafurable of themfelves : partly from its affociation with the pleafures of power. Such is the cafe alfo with the pleafure of good luck, when afforded by fuch incidents as compofe the game of hazard, or any ather game of chance, when played at for nothing. This derives its pleafurable quality from its affociation with one of the pleafures of wealth; to wit, with the pleafure of acquiring it.

XVI.

14. Pleafure of relief.

1. Pains of privation.

There include, 1. Pains of defire.
14. Farther on we thall fee pains grounded upon pleafures; in like manner may we now fee pleafures grounded upon pains. To the catalogue of pleafures may accordingly be added the pleafures of relief: or, the pleafures which a man experiences when, after he has been enduring a pain of any kind for a certain time, it comes to ceafe, or to abate. Thefe may of courfe be diftinguifhed into as many fpecies as there are of pains : and may give rife to fo many pleafures of memory, of imagination, and of expectation.

XVII.

I. Pains of privation are the pains that may refult from the thought of not poffeffing in the time prefent any of the feveral kinds of pleam fures. Pains of privation may accordingly be refolved into as many kinds as there are of pleafures to which they may correfpond, and from the abfence whereof they may be derived.

\section{XVIII.}

There are three forts of pains which are only fo many modifications of the feveral pains of privation. When the enjoyment of any parti- 
cular pleafure happens to be particularly defired, but without any ex- INTROD. pectation approaching to affurance, the pain of privation which thereupon refults takes a particular name, and is called the pain of defire, or of unfatisfied defire.

XIX.

Where the enjoyment happens to have been looked for with a de- 2. Pains of gree of expectation approaching to affurance, and that expectation is difappointmade fuddenly to ceafe, it is called a pain of difappointment.

$\mathrm{XX}$.

A pain of privation takes the name of a pain of regret in two cafes: 3 . Pains of I. Where it is grounded on the memory of a pleafure, which having regret. been once enjoyed, appears not likely to be enjoyed again: 2. Where it is grounded on the idea of a pleafure, which was never actually enjoyed, nor perhaps fo much as expected, but which might have been enjoyed (it is fuppofed) had fuch or fuch a contingency happened, which, in fact, did not happen.

XXI.

2. The feveral pains of the fenfes feem to be as follows: I. The pains 2. Pains of of hunger and thirft: or the difagreeable fenfations produced by the the fenfes. want of fuitable fubftances which need at times to be applied to the alimentary canal. 2. The pains of the tafte: or the difagreeable fenfations produced by the application of various fubftances to the palate, and other fuperior parts of the fame canal. 3. The pains of the organ of friell: or the difagreeable fenfations produced by the effuvia of various fubftances when applied to that organ. 4. The pains of the touch: or the difagreeable fenfations produced by the application of various fubftances to the $\mathrm{k}$ kin. 5. The fimple pains of the hearing: or the difagreable fenfations excited in the organ of that fenfe by various kinds of founds : independently (as before) of affociation. 6. The fimple pains of the fight: or the difagreeable fenfations, if any fuch there be, that may be excited in the organ of that fenfe by vifible images, independent of the principle of affociation. 7. "The

c The pleafure of the venereal fenfe feems to have no pofitive pain to correfpond to Nopofitive pains it: it has only a pain of privation, or pain of the mental clafs, the pain of unfatisfied corsefpund to defire. If any pofitive pain of body refult from the want of fuch indulgence, it be- the pleafure of longs to the head of pains of difeafe. 
INTROD. pains refulting from exceffive heat or cold, unlefs thefe be referable to Cй $\bar{x}$. V. the touch. 8. The pains of difeafe: or the acute and uneafy fenfations refulting from the feveral difeafes and indifpofitions to which human nature is liable. 9. The pain of exertion, whether bodily or mental: or the uneafy fenfation which is apt to accompany any intenfe effort, whether of mind or body.

\section{XXII.}

3. Pains of

3. "The pains of awkwardnefs are the pains which fometimes reawkward. nefs. fult from the unfuccefsful endeavour to apply any particular inftruments of enjoyment or fecurity to their ufes, or from the difficulty a man experiences in applying them ${ }^{e}$.

XXIII.

A. Pains of enmity.

4. The pains of enmity are the pains that may accompany the perfuafion of a man's being obnoxious to the ill-will of fuch or fuch an affignable perfon or perfons in particular: or, as the phrafe is, of being upon ill terms with him or them: and, in confequence, of being obnoxious to certain pains of fome fort or other, of which he may be the caufe.

\section{XXIV.}

5. Pains of 5. The pains of an ill-name, are the pains that accompany the peran ill-name. fuafion of a man's being obnoxious, or in a way to be obnoxious to the ill-will of the world about him. Thefe may likewife be called the

a The pleafures of novelty have no pofitive pains correfponding to them. The pain which a man experiences when he is in the condition of not knowing what to do with himfelf, that pain, which in French is expreffed by a fingle word ennui, is a pain of privation : a pain refulting from the abfence, not only of all the pleafures of novelty, but of all kinds of pleafure whatfoever.

nor to thor

The pleafures of wealth have alfo no pofitive pains correfponding to them : the only pains oppored to them are pains of privation. If any pofitive pains refult from the want of wealth, they are referable to fome other clafs of pofitive pains; principally to thofe of the fenfes. From the want of food, for inttance, refult the pains of hunger ; from the want of cloathing, the pains of cold; and fo forth.

- It may be a queftion, perhaps, whether this be a pofitive pain of itfelf, or whether privation? it be nothing more than a pain of privation, refulting from the confcioufnefs of a want of fkill. It is, however, but a queftion of words, nor does it matter which way it be determined. 
pains of ill-repute, the pains of difhonour, or the pains of the moral INTROD. fanction'.

\section{XXV.}

6. 8 The pains of piety are the pains that accompany the belief of 6. Pains of a man's being obnoxious to the difpleafure of the Supreme Being: and in confequence to certain pains to be inflicted by his efpecial appointment, either in this life or in a life to come. Thefe may aifo be called the pains of religion; the pains of a religious difpofition; or the pains of the religious fanction. When the belief is looked upon as wellgrounded, thefe pains are commonly called religious terrors; when looked upon as ill-grounded, fuperftitious terrors ${ }^{h}$.

\section{XXVI.}

7. The pains of benevolence are the pains refulting from the view of any pains fuppofed to be endured by other beings. Thefe may alfo be called the pains of good-will, of fympathy, or the pains of the benevolent or focial affections.

\section{XXVII.}

8. The pains of malevolence are the pains refulting from the view of any pleafures fuppofed to be enjoyed by any beings who happen to be the objects of a man's difpleafure. Thefe may alfo be ftiled the

\footnotetext{
$f$ In as far as a man's fellow-creatures are fuppofed to be determined by any event not to regard him with any degree of efteem or good will, or to regard him with a lefs degree of efteem or good will than they would otherwife; not to do him any forts of good offices, or not to do him fo many good offices as they would otherwife; the pain refulting from fuch confideration may be reckoned a pain of privation : as far as they are fuppofed to regard him with fuch a degree of averfion or difefteem as to be difpofed to do him pofitive ill offices, it may be reckoned a pofitive pain. The pain of privation, and the pofitive pain, in this cafe run one into another indiftinguinably. .
}

There feem to be no pofitive pains to correfpond to the pleafures of power. The pains that a man may feel from the want or the lofs of power, in as far as power is diftinguifhed from all other fources of pleafure, feem to be nothing more than pains of privation.

h The pofitive pains of piety, and the pains of privation, oppofed to the pleafures of piety, run one into another in the fame manner as the pofitive pains of enmity, or of an ill name, do with refpect to the pains of privation, oppofed to the pleafures of amity, and thofe of a good name. If what is apprehended at the hands of God is barely the not receiving pleafure, the pain is of the privative clafs: if, moreover, actual pain be apprehended, it is of the clafs of pofitive pains. 
Xxxviii

INTROD.

Chat. V.

9. Pains of the memory.

10. Pains of the imagination.

11. Pains of expectation.

2. Pains of affociation.

Pleafures and pains are either felf-

regarding or extra-regarding.

* See oh. $x$. [Motiyes.]

In what ways the law is concerned

with the above pains and pleafures.

Pleafures and pains of a mity and enmity dif tinguined from thofe of benerolence and malevolence.

\section{[PLEASURES AND PAINS] their Kinds.}

pains of ill-will, of antipathy, or the pains of the malevolent or diffocial affections.

\section{XXVIIII.}

9. The pains of the memory may be grounded on every one of the above kinds, as well of pains of privation as of pofitive pains. Thefe correfpond exactly to the pleafures of the memory.

XXIX.

10. The pains of the imagination may alfo be grounded on any one of the above kinds, as well of pains of privation as of pofitive pains : in other refpects they correfpond exactly to the pleafures. of the imagination.

\section{$\mathrm{XXX}$.}

ix. The pains of expectation may be grounded on each one of the above kinds, as well of pains of privation as of pofitive pains. There may be alfo termed pains of apprehenfion.

\section{$\mathrm{XXXI}$}

12. The pains of affociation correfpond exactly to the pleafures of affociation.

\section{XXXII.}

Of the above lift there are certain pleafures and pains which fuppofe. the exiftence of fome pleafure or pain of fome other perfon, to which. the pleafure or pain of the perfon in queftion has regard: fuch pleafures and pains may be termed extra-regarding. Others do not fuppofe any. fuch thing: thefe may be termed felf-regarding *. The only pleafures and pains of the extra-regarding clafs are thofe of benevolence, and thofe of malevolence: all the reft are felf-regarding;.

\section{XXXIII.}

Of all thefe feveral forts of pleafures and pains, there is fcarce any one which is not liable, on more accounts than one, to come under the confideration of the law. Is an offence committed? it is the tendency which it has to deftroy, in fuch or fuch perfons, fome of thefe pleafures, or to produce fome of thefe pains, that conftitutes the mifchief of it, and the

i By this means the pleafures and pains of amity may be the more clearly diftinguifhed from thofe of benevolence: and on the other hand, thofe of enmity from thofe of malevolence. The pleafures and pains of amity and enmity are of the felf-regarding caft: thofe of benevolence and malevolence of the extra-regarding. 


\section{[PLEASURES AND PAINS] their Kinds.}

ground for punifhing it. It is the profpect of fome of thefe pleafures, or of fecurity from fome of thefe pains, that conftitutes the motive or temptation, it is the attainment of them that conftitutes the profit of Chap. V. the offence. Is the offender to be punifhed? It can be only by the production of one or more of thefe pains, that the punifhment can be inficted ${ }^{\mathrm{k}}$.

$k$ It would be a matter not only of curiofity; but of fome $u$ fe, to exhibit a catalogue of the feveral complex pleafures and pains, analyzing them at the fame time into the feveral fimple ones, of which they are refpectively compofed. But fuch a difquifition would take up too much room to be admitted here. A fhort fpecimen, however, for the purpofe of illuftration, can hardly be difpenfed with.

The pleafures taken in at the eye and ear are generally very complex. The pleafures of a country fcene, for inftance, confin commonly, amongt others, of the following pleafures:

\section{Pleafures of the fenfes.}

x. The fimple pleafures of fight, excited by the perception of agreeable colours and figures, green fields, waving foliage, gliftening water, and the like.

2. The fimple pleafures of the ear, excited by the perceptions of the chirping of birds, the murmuring of waters, the rufling of the wind among the trees.

3. The pleafures of the fmell, excited by the perceptions of the fragrance of nowers, of new-mown hay, or other vegetable fubftances, in the firt ftages of fermentation.

4. The agreeable inward fenfation, produced by a brifk circulation of the blood, and the ventilation of it in the lungs by a pure air, fuch as that in the country frequently is in comparifon of that which is breathed in towns.

II. Pleafures of the imagination produced by affociation.

1. The idea of the plenty, refulting from the poffeffion of the objects that are in view, and of the happinefs arifing from it.

2. The idea of the innocence and happinefs of the birds, heep, cattle, dogs, and other gentle or domeftic animals.

3. The idea of the conftant flow of health, fuppofed to be enjoyed by all thefe creatures: a notion which is apt to refult from the occafional flow of health enjoyed by the fuppofed fpectator.

4. The idea of gratitude, excited by the contemplation of the all-powerfui and beneficent Being, who is looked up to as the author of thefe bleffings.

Thefe four laft are all of them, in fome meafure at leaft, pleafures of fympathy.

The depriving a man of this groupe of pleafures is one of the evils apt to refult from imprifonment; whether produced by illegal violence, or in the way of punifhment, by appointment of the law's.

C H A P. 


\author{
C H A P. VI.
}

I.

INTROD. DAIN and pleafure are produced in men's minds by the action of Снар. VI. 1 certain caufes. But the quantity of pleafure and pain runs not Pain and pleafure not uniformly proportioned caufes. uniformly in proportion to the caufe; in other words, to the quantity of force exerted by fuch caufe. The truth of this obfervation refts not upon any metaphyfical nicety in the import given to the terms caufe, quantity, and force: it will be equally true in whatfoever manner fuch force be meafured.

\title{
II.
}

Degree or quantum of fenfibility, what.

The difpofition which any one has to feel fuch or fuch a quantity of pleafure or pain, upon the application of a caufe of given force, is what we term the degree or quantum of his fenfibility. This may be either general, referring to the fum of the caufes that act upon him during a given period: or particular, referring to the action of any one particular caufe, or fort of caufe.

III.

Bias or qua- But in the fame mind fuch and fuch caufes of pain or pleafure will bility, what. produce more pain or pleafure than fuch or fuch other caufes of pain or pleafure: and this proportion will in different minds be different. The difpofition which any one has to have the proportion in which he is affected by two fuch caufes, different from that in which another man is affected by the fame two caufes, may be termed the quality or bias of his fenfibility. One man, for inftance, may be moft affected by the pleafures of the tafte; another by thofe of the ear. So alfo, if there be a difference in the nature or proportion of two pains or pleafures which they refpectively experience from the fame caufe: a cafe not fo frequent as the former. From the fame injury, for inftance, one man may feel the fame quantity of grief and refentment together as another man: but one of them hall feel a greater thare of grief than of refintment: the other, a greater thare of refentment than of grief. 


\section{of Circumfances infuencing [S E N S I B I L I T Y.]}

IV.

INTROD.

Any incident which ferves as a caufe, either of pleafure or of pain, may be termed an exciting caufe: if of pleafure, a pleafurable caufe : if of pain, a painful, afflikive, or dolorific caufe ${ }^{2}$.

$\mathrm{V}$.

Chap. VI.

Exciting

caures plea-

furable and dolorific.

Now the quantity of pleafure, or of pain, which a man is liable to Circumexperience upon the application of an exciting caufe, fince they will ftances inexperience upon the application of an exciting caufe, fince they will fluencing not depend altogether upon that caufe, will depend in fome meafure fenfibility, upon fome other circumftance or circumftances: thefe circumftances, whatfoever they be, may be termed circumftances influencing fenfibility ${ }^{\mathrm{b}}$.

VI.

Thefe circumftances will apply differently to different exciting Circumcaufes; infomuch that to a certain exciting caufe, a certain circum- ftances inftance thall not apply at all, which thall apply with great force to another exciting caufe. But without entering for the prefent into thefe diftinctions, it may be of ufe to fum up all the circumftances which can be found to influence the effect of any exciting caufe. Thefe, as on a former occafion, it may be as well firft to fum up together in the concifeft manner poffible, and afterwards to allot a few words to the feparate explanation of each article. They feem to be as follows: 1. Health. 2. Strength. 3. Hardinefs. 4. Bodily imperfection. 5. Quantity and quality of knowledge. 6. Strength of intellectual powers. 7. Firmnefs of mind. 8. Steadinefs of mind. 9. Bent of

2 The exciting caufe, the pleafure or pain produced by it, and the intention produced by fuch pleafure or pain in the character of a motive, are objects fo intimately connected, that, in what follows, I fear I have not, on every occafion, been able to keep them fufficiently diftinet. I thought it neceffary to give the reader this warning; after which, thould there be found any fuch miftakes, it is to be hoped they will not be productive of much confufion.

b Thus, in phyfical bodies, the momentum of a ball put in motion by impulfe, will be influenced by the circumftance of gravity : being in fome directions encreafed, in others diminifhed by it. So in a hip, put in motion by the wind, the momentum and direction will be influenced not only by the attraction of gravity, but by the motion and refiftance of the water, and feveral other circumftances.

Vor. I.

Auencing fenfibility enumerated. 
INTROD. inclination. 10. Moral fenfibility. I1. Móral biafes. 12. Religious Сняр. VI. fenfibility. 13. Religious biafes. 14. Sympathetic fenfibility. 15. Sympathetic biafes. 16. Antipathetic fenfibility. I7. Antipathetic biafes. 18. Infanity. 19. Habitual occupations. 20. Pecuniary circumftances. 21 . Connections in the way of fympathy. 22. Connections in the way of antipathy. 23. Radical frame of body. 24. Radical frame of mind. 25. Sex. 26. Age. 27. Rank. 28. Education. 29. Climate. 30. Lineage. 3r. Government. 32. Religious profefion ${ }^{c}$.

Extent and intricacy of this fubject.
- An analytical view of all thefe circumftances will be given at the conclufion of the chapter : to which place it was neceffary to refer it, as it could not well have been underftood, till fome of them had been previoully explained.

To fearch out the vant variety of exciting or moderating caufes, by which the degree, or bias of a man's fenfibility may be infuenced, to define the boundaries of each, to extricate them from the entanglements in which they are involved, to lay the effect of each article diftinetly before the reader's eye, is, perhaps, if not abfolutely: the moft difficult tak, at leaft one of the molt difficult tafks, within the compars of moral phyfiology. Difquifitions on this head can never be compleatly fatisfactory: without examples. To proxide a fufficient collection of fuch examples, would be a work of great labour as well as nicety : hiftory and biographiy wonld need to be ranfacked : a: vaft courfe of reading would need to be travelled through on purpoie. By fuch a procefo the prefent work would doubtlefs have been rendered more amufing; but in point of bulk, fo enormous, that this fingle chapter would have been fwelled into a confiderable. volume. Feigned cafes, although they may upon occafion ferve to render the general matter tolerably intelligible, can never be fufficient to render it palatable. On this therefore, as on fo many other occafions, I muft confine myfelf to dry and general inftruction : difcarding illuftration, although fenfible that without it inftruction cannot manifelt half its efficacy. The fubject, however, is fo difficult, and fo new; that $I$ thall think I have not ill fucceeded, if, without pretending to exhauft it, I thall have been able to mark out the principal points of view, and to put the matter in fuch a method as may facilitate the refearches of happier enquirers.

The great dificulty lies in the nature of the words; which are not, like pain and plea. fure, names of homogeneous real entities, but names of various fietitious entities, for which no common genus is to be found: and which therefore, without a vaft and roundabout chain of inveftigation, can never be brought under any exhautive plan of arrangement, but muft be picked up here and there as they happen to occur.

VII. I. 


\section{VII.}

INTROD.

1. Health is the abfence of difeafe, and confequently of all thofe kinds of pain which are among the fymptoms of difeafe. A man may be faid to be in a ftate of health, when he is not confcious of any uneafy fenfations, the primary feat of which can be perceived to be

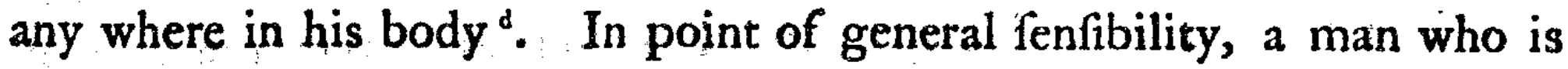
under the preffure of any bodily indifpofition, or, as the phrafe is, is in an ill ftate of health, is lefs fenfible to the influence of any pleafureable caufe, and more fo to that of any afflictive one, than if he were well.

\section{VIII.}

2. The circumftance of ftrength, though in point of caufality 2. Strength. clofely connected with that of health, is perfectly diftinguihable from it. The fame man will indeed generally be ftronger in a good ftate of health than in a bad one. But one man, even in a bad ftate of health, may be ftronger than another even in a good one. Weaknefs is a common concomitant of difeafe : but in confequence of his radical frame of body, a man may be weak all his life long, without experiencing any difeafe. Health, as we have obferved, is principally a negative circumftance: ftrength a pofitive one. The degree of a man's ftrength can be meafured with tolerable accuracy ${ }^{\circ}$.

IX.

3. Hardinefs is a circumftance which, though clofely connected with 3. Hardinefs. that of ftrength, is diftinguifhable from it. Hardinefs is the abfence of irritability. Irritability refpects either pain, refulting from the action of mechanical caufes; or difeafe, refulting from the action of caufes

purely

- It may be thought, that in a certain degree of health, this negative account of the matter hardly comes up to the cafe. In a certain degree of health, there is often fuch 2 kind of feeling diffufed over the whole frame, fuch a comfortable feel, or flow of fpirits, as it is called, as may with propriety come under the head of pofitive pleafure. But without experiencing any fuch pleafurable feeling, if a man experience no painful one, he may be well enough faid to be in health.

- The moft accurate meafure that can be given of a man's ftrength, feems to be Meafure of that which is taken from the weight or number of pounds and ounces he can lift with firength, the his hands in a given attitude. This indeed relates immediately only to his arms : but can lifto

G $\rightarrow$ there 
INTROD. purely phyfiological. Irritability, in the former fenfe, is the difpofition С mechanical caufe; fuch as are moft of thofe applications by which fimple affictive punifhments are inflicted, as whipping, beating, and the like. In the latter fenfe, it is the difpofition to contract difeafe with greater or lefs facility, upon the application of any inftrument acting on the body by its phyfiological properties, as in the cafe of fevers, or of colds, or other inflammatory difeafes, produced by the application of damp air: or to experience immediate uneafinefs, as in the cafe of relaxation or chillinefs produced by an over or under proportion of the matter of heat.

Difference

between

ftrength and

hardinefs.

Hardinefs, even in the fenfe in which it is oppofed to the action of mechanical caufes, is diftinguimable from ftrength." The external indications of ftrength are the abundance and firmnefs of the mufcular fibres: thofe of hardinefs, in this fenfe, are the firmnefs of the mufcular: fibres, and the callofity of the fkin. Strength is more peculiarly the gift of nature: hardinefs, of education. Of two perfons who have had, the one the education of a gentleman, the other, that of a common failor, the firft may be the ftronger, at the fame time that the other is the hardier.

\section{$\mathrm{X}$.}

4. Bodily

4. By bodily imperfection may be underftood that condition which imperfection.

a perfon is in, who either ftands diftinguifhed by any remarkable deformity, or wants any of thofe parts or faculties, which the ordinary run of perfons of the fame fex and age are furnifhed with: who, for

thefe are the organs of Atrength which are moft employed; of which the ftrength correfponds with moft exactnefs to the general ftate of the body with regard to ftrength : and in which the quantum of ftrength is eafieft meafured. Strength may accordingly: be difinguithed into ganeral and particular.

Weaknefs is a negative term, and imports the abfence of ftrength. It is, befides, a relative term, and accordingly imports the abfence of foch a quantity of frength as makes the thare, poffeffed by the perfon in quetion, lefs than that of fome perfon he is compared to. Weaknefs, when it is at fuch a degree as to make it painful for a man to perform the motions neceffary to the going through the ordinary fundtions of life, fuch as to get up, to walk, to drefs one's felf, and fo forth, brings the circumftance of health into queftion, and puts a man into that fort of condition in which he is faid to be in ill health.

inftance, 
inftance, has a hare-lip, is deaf, or has loft a hand. This circumftance, INTROD. like that of ill-health, tends in general to diminifh more or lefs the Crap. Vi. effect of any pleafurable circumftance, and to encreafe that of any afflictive one. The effect of this circumftance, however, admits of great variety: inafmuch as there are a great variety of ways in which a man may fuffer in his perfonal appearance, and in his bodily organs and faculties: all which differences will be taken notice of in their proper places*.

$\mathrm{XI}$.

5. So much for circumftances belonging to the condition of the body: 5. Quantity we come now to thofe which concern the condition of the mind : the and quality ufe of mentioning thefe will be feen hereafter. In the firft place may be ledge. reckoned the quantity and quality of the knowledge the perfon in queftion happens to poffers: that is, of the ideas which he has actually in ftore, ready upon occafion to call to mind: meaning fuch ideas as are in fome way or other of an interefting nature: that is, of a nature in fome way or other to influence his happinefs, or that of other men. When thefe ideas are many, and of importance, a man is faid to be a man of knowledge; when few, or not of importance, ignorant.

\section{XII.}

6. By ftrength of intellectual powers may be underftood the degree of 6. Strength facility which a man experiences in his endeavours to call to mind as of intellecwell fuch ideas as have been already aggregated to his ftock of knowledge, as any others, which, upon any occafion that may happen, he may conceive a defire to place there. It feems to be on fome fuch occafion as this that the words parts and talents are commonly employed. To this head may be referred the feveral qualities of readinefs of apprehenfion, accuracy and tenacity of memory, ftrength of attention, clearnefs of difcernment, amplitude of comprehenfion, vividity and rapidity of imagination. Strength of intellectual powers, in general, feems to correfpond pretty exactly to general ftrength of body: as any of thefe qualities in particular does to particular ftrength.

XIII.

7. Firmnefs of mind on the one hand, and irritability on the other, re7. Firmners of mind.

- See B. I. Tit. [Irrep, corp. Injuries.] 
INTROD. gard the proportion between the degrees of efficacy with which a man Chap. VI. is acted upon by an exciting caufe, of which the value lies chiefly in magnitude, and one of which the value lies chiefly in propinquity". A man may be faid to be of a firm mind, when fmall pleafures or pains, which are prefent or near, do not affect him, in a greater proportion to their value, than greater pleafures or pains, which are uncertain or remote $^{f}$ : of an irritable mind, when the contrary is the cafe.

XIV.

8. Steadi- 8. Steadinefs regards the time during which a given exciting caufe of nefs. a given value continues to affect a man in nearly the fame manner and degree as at firt, no affignable external event or change of circumitances intervening to make an alteration in its force *.

$\mathrm{XV}$.

9. Bent of $9 y$ the bent of a man's inclinations may be underftood the propeninclinations. fity he has to expect pleafure or pain from certain objects, rather than from others. A man's inclinations may be faid to have fuch or fuch a bent, when, amongtt the feveral forts of objects which afford pleafure in fome degree to all men, he is apt to expect more pleafure from one particular fort, than from another particular fort, or more from any given particular fort, than another man would expect from that fort; or when, amongit the feveral forts of objects, which to one man afford pleafure, whilf to another they afford none, he is apt to expect, or not to expect, pleafure from an object of fuch or fuch a fort: fo alfo with regard to pains. This circumftance, though intimately connected with that of the bias of a man's fenfibility, is not undiftinguifhable

When, for inftance, having been determined, by the profpect of fome inconvenience, not to difclofe a fact, although he thould be put to the rack, he parfeveres in fuch refolution after the rack is brought into his prefence, and even applied to him.

The facility with which children grow tired of their play-things, and throw them away, is an inftance of unfteadinefs: the perfeverance with which a merchant applies himfelf to his traffic, or an author to his book, may be taken for an inftance of the contrary. It is difficult to judge of the quantity of pleafure or pain in thefe cafes, but from the effects which it produces in the character of a motive: and even then it is difficult to pronounce, whether the change of conduct happens by the extinction of the old pleafure or pain, or by the intervention of a new one.

- See ch. iv. [Value.] 
from it. The quantity of pleafure or pain, which on any given occafion a man may experience from an application of any fort, may be greatly influenced by the expectations he has been ufed to entertain of pleafure or pain from that quarter ; but it will not be abfolutely determined by them: for pleafure or pain may come upon him from a quarter from which he was not accultomed to expectit.

\section{XVI.}

10. The circumftances of moral, religious, fympatbetic, and antipatbetic fenfibility, when clofely confidered, will appear to be included in fome fort under that of bent of inclinations. On: account of their particular importance they may, however; be worth mentioning apart.. A man's moral fenfibility may be:faid to be ftrong, when the pains and pleafures of the moral fanction: ${ }^{*}$ thew greater in his eyes, in comparifon with other pleafures and pains (and confequently exert a ftronger influence) than in the eyes of the perfons he is compared with; in other words, when he is acted on with more than ordinary efficacy by the fenfe of honour : it may be faid to be weak, when the contrary is the cafe.

\section{XVII.}

1T. Moral fenfibility feems to regard the average effect or infuence of the pains and pleafures of the moral fanction, upon all forts of occafions to which it is applicable, or happens to be applied. It regards the average force or quantity of the impulfes the mind receives from that fource during a given period. Moral bias regards the particular:acts on which, upon fo many particular occafions, the force of that fanction is looked upon as attaching. It regards the quality or direction of thofe impulfes. It admits of as many varieties, therefore, as there are dictates which the moral fanction may be conceived to iffue forth. A man may be faid to have fuch or fuch a moral bias, or to have a moral bias in favour of fuch or fuch an action, when he looks upon it as being of the number of thofe of. which the performance is dictated by the moral fanction.

\section{XVIII.}

12. What has been faid with regard to moral fenfibility, may be applied, mutatis mutandis, to religious.

$$
\text { - See ch. v. [Pleafures and Pains.] }
$$


INTROD.

XIX.

ChaP. VI.

13. Religious biafes.

13. What has been faid with regard to moral biafes, may alfo be applied, mutatis mutandis, to religious biafes.

$\mathrm{XX}$.

14. Sympathetic fenfibility.

14. By fympathetic fenfibility is to be underftood the propenfity that a man has to derive pleafure from the happinefs, and pain from the unhappinefs, of other fenfitive beings. It is the ftronger, the greater the ratio of the pleafure or pain he feels on their account is to that of the pleafure or pain which (according to what appears to him) they feel for themfelves.

XXI.

15. Sympa- 15. Synpathetic bias regards the defcription of the parties who are thetic biafes. the objects of a man's fympathy: and of the acts or other circumftances of or belonging to thofe perfons, by which the fympathy is excited. Thefe parties may be, I. Certain individuals. 2. Any fubordinate clars of individuals. 3. The whole nation. 4. Human kind in general. 5. The whole fenfitive creation. According as thefe objects of fympathy are more numerous, the affection, by which the man is biafed, may be faid to be the more enlarged.

\section{XXII.}

16,17. An tipathetic fenfibility,

16, 17. Antipathetic fenfibility and antipathetic biafes are juft the reverfe of fympathetic fenfibility and fympathetic biafes. By antipathetic fenfibility is to be underftood the propenfity that a man has to derive pain from the happinefs, and pleafure from the unhappinefs, of other fenfitive beings.

\section{XXIII.}

18. Infanity. 18. The circumftance of infanity of mind correfponds to that of bodily imperfection. It admits, however, of much lefs variety, inafmuch as the foul is (for aught we can perceive) one indivifible thing, not diftinguifhable, like the body, into parts. What leffer degrees of imperfection the mind may be fufceptible of, feem to be comprizable under the already-mentioned heads of ignorance, weaknefs of mind, irritability, or unfteadinefs; or under fuch others as are reducible to them. Thofe which are here in view are thofe extraordinary fpecies and degrees of mental imperfection, which, wherever they take place, are as con- 
fpicuous and as unqueftionable as lamenefs or blindnefs in the body: operating partly, it Thould feem, by inducing an extraordinary degree of the imperfections above mentioned, partly by giving an extraordinary and prepofterous bent to the inclinations.

\section{XXIV.}

I9. Under the head of a man's habitual occupations, are to be underftood, on this occafion, as well thofe which he purfues for the fake of profit, as thofe which he purfues for the fake of prefent pleafure. The confideration of the profit itfelf belongs to the head of a man's pecuniary circumftances. It is evident, that if by any means a punifliment, or any other exciting caufe, has the effect of putting it out of his power to continue in the purfuit of any fuch occupation, it mult on that account be fo much the more diftreffing. A man's habitual occupations, though intimately connected in point of caufality with the bent of his inclinations, are not to be looked upon as precifely the fame circumftance. An amufement, or channel of profit, may be the object of a man's inclinations, which has never been the fubject of his babitual occupations: for it may be, that though he wirhed to betake himfelf to it, he never did, it not being in his power: a circumftance which may make a good deal of difference in the effect of any incident by which he happens to be debarred from it.

\section{XXV.}

20. Under the head of pecuniary circumftances, I mean to bring to view the proportion which a man's means bear to his wants: the fum total of his means of every kind, to the fum total of his wants of every kind. A man's means depend upon three circumftances: I. His property. 2. The profit of his labour. 3. His connections in the way of fupport. His wants feem to depend upon four circumftances. 1. His habits of expence. 2. His connections in the way of burthen. 3. Any prefent cafual demand he may have. 4. The ftrength of his expectation. By a man's property is to be underftood, whatever he has in ftore independent of his labour. By the profit of his labour is to be underftood the growing profit. As to labour, it may be either of the body principally, or of the mind principally, or of both inVol.. I. 
Of Circumfances influencing [S E N S I B I L I T Y.]

INTROD. differently: nor does it matter in what manner, nor on what fubject, it CHap. VI. be applied, fo it produce a profit. By a man's connections in the way of fupport, are to be underitood the pecuniary affiftances, of whatever kind, which he is in a way of receiving from any perfons who, on whatever account, and in whatever proportion, he has reafon to expect fhould contribute gratis to his maintenance: fuch as his parents, patrons, and relations. It feems manifeft, that a man can have no other means than thefe. What he ufes, he muft have either of his own, or from other people: if from other people, either gratis or for a price. As to habits of expence, it is well known, that a man's defires are governed in a great degree by his habits. Many are the cafes in which defire (and confequently the pain of privation connected with it*) would not even fubfift at all, but for previous enjoyment. By a man's connections in the way of burthen, are to be underftood whatever expence he has reaton to look upon himfelf as bound to be at in the fupport of thofe who by law, or the cuftoms of the world, are warranted in looking up to him for affiftance; fuch as children, poor relations, fuperannuated fervants, and any other dependents whatfoever. As to prefent cafual demand, it is manifent, that there are occafions on which a given fum will be worth infinitely more to a man than the fame fum would at another time: where, for example, in a cafe of extremity, a man ftands in need of extraordinary medical affiftance: or wants money to carry on a law-fuit, on which his all depends : or has got a livelihood waiting for him in a diftant country, and wants money for the charges of conveyance. In fuch cafes, any piece of good or ill fortune, in the pecuniary way, might have a very different effect from what it would have at any other time. With regard to ftrength of expectation; when one man expects to gain or to keep a thing which another does not, it is plain the circumftance of not having it will affect the former very differently from the latter; who, indeed, commonly will not be affected by it at all.

XXVI.

21. Connections in the way of fympathy.
21. Under the head of a man's connections in the way of fympathy, $I$

* See ch. v. [Pleafures and Pains.] 
would bring to view the number and defcription of the perfons in whofe INTROD. welfare he takes fuch a concern, as that the idea of their happinefs fhould be productive of pleafure, and that of their unhappinefs of pain to him: for inftance, a man's wife, his children, his parents, his near relations, and intimate friends. This clafs of perfons, it is obvious, will for the moft part include the two claffes by which his pecuniary circumftances are affected: thofe, to wit, from whofe means he may expect fupport, and thofe whofe wants operate on him as a burthen. But it is obvious, that befides thefe, it may very well include others, with whom he has no fuch pecuniary connection: and even with regard to thefe, it is evident that the pecuniary dependence, and the union of affections, are circumftances perfectly diftinguifhable. Accordingly, the connections here in queftion, independently of any influence they may have on a man's pecuniary circumftances, have an influence on the effect of any exciting caufes whatfoever. The tendency of them is to increafe a man's general fenfibility; to increafe, on the one hand, the pleafure produced by all pleafurable caufes; on the other, the pain produced by all afflictive ones. When any pleafurable incident happens to a man, he naturally, in the firft moment, thinks of the pleafure it will afford immediately to himfelf : prefently afterwards, however (except in a few cafes, which it is not worth while here to infift on) he begins to think of the pleafure which his friends will feel upon their coming to know of it: and this fecondary pleafure is commonly no mean addition to the primary one. Firft comes the felf-regarding pleafure : then comes the idea of the pleafure of fympathy, which you fuppofe that pleafure of your's will give birth to in the bofom of your friend: and this idea excites again in your's a new pleafure of fympathy, grounded upon his. The firft pleafure iffuing from your own bofom, as it were from a radiant point, illuminates the bofom of your friend: reverberated from thence, it is reflected with augmented warmth to the point from whence it firtt proceeded: and fo it is with pains".

Nor

1. This is one reafon why legiflators in general like better to have married people to deal with than fingle; and people that have children than fuch as are childlefs. It is 
INTROD. Nor does this effect depend wholly upon affection. Among near Crap. VI. relations, although there thould be no kindnefs, the pleafures and pains of the moral fanction are quickly propagated by a peculiar kind of fympatiny: no article, either of honour or difgrace, can well fall upon a man, without extending to a certain diftance within the circle of his family. What reflects honour upon the father, reflects honour upon the fon: what reflects difgrace, difgrace. The caufe of this fingular and feemingly unreafonable circumftance (that is, its analogy to the reft of the phrnomena of the human mind) belongs not to the prefent purpofe. It is fufficient if the effect be beyond difpute.

XXVII.

22. Connections in the way of antipathy.

22. Of a man's connections in the way of antipathy, there needs not any thing very particular to be oblerved. Happily there is no primeval and conftant fource of antipathy in human nature, as there is of fympathy. There are no permanent fets of perfons who are $r: 0$ turally and of courfe the objects of antipathy to a man, as there are who are the objects of the contrary affection. Sources, however, but too many, of antipathy, are apt to fpring up upon various occafions during the courfe of a man's life: and whenever they do, this circumftance may have a very confiderable influence on the effects of various exciting caufes. As on the one hand a punimment, for inftance, which tends to feparate a man from thofe with whom he is connected in the way of fympathy, fo on the other hand, one which tends to force him into the company of thofe with whom he is connected in the way of antipathy, will, on that account, be fo much the more diftreffing. It is to be obferved, that fympathy itfelf multiplies the fources of antipathy. Sympathy for your friend gives birth to antipathy on your part againft all thofe who are objects of antipathy, as well as to fympathy for thofe who are objects of fympathy to bim. In the fame manner does antipathy multiply the fources of fympathy; though commonly perhaps with rather a lefs degree of efficacy. Antipathy againit

manifeft that the Atronger and more numerous a man's connections in the way of fympathy are, the fronger is the hold which the law has upon him. A wife and children are fo many pledges a man gives to the world for his good behaviour. 
your enemy is apt to give birth to fympathy on your part towards thofe who are objects of antipathy, as well as to antipathy againft thofe who are objects of fympathy, to bim.

\section{XXVIII.}

23. Thus much for the circumftances by which the effect of any exciting caufe may be influenced, when applied upon any given occafion, at any given period. But befides thefe fupervening incidents, there are other circumftances relative to a man, that may have their influence, and which are co-eval to his birth. In the firft place, it feems to be univerfally agreed, that in the original frame or texture of every man's body, there is a fomething which, independently of all fubfequently intervening circumftances, renders him liable to be affected by caufes producing bodily pleafure or pain, in a manner different from that in which another man would be affected by the fame caufes. To the catalogue of circumftances influencing a man's fenfibility, we may therefore add his original or radical frame, texture, conftitution, or temperament of body.

\section{XXIX.}

24. In the next place, it feems to be pretty well agreed, that there is fomething alfo in the original frame or texture of every man's mind, which, independently of all exterior and fubfequently intervening circumftances, and even of his radical frame of body, makes him liable to be differently affected by the fame exciting caufes, from what another man would be. To the catalogue of circumftances influencing a man's fenfibility, we may therefore further add his original or radical frame, texture, conftitution, or temperament of mind $\mathrm{s}$

\section{XXX.}

It feems pretty certain, all this while, that a man's fenfibility to caufes producing pleafure or pain, even of mind, may depend in a confiderable degree upon his original and acquired frame of body.

The characteriftic circumftances whereby one man's frame of body or mind, confidered at any given period, Itands diftinguilhed from that of another, have been comprized by metaphyficians and phyfiologitts under the name idiofyncrofy, from ibus, peculiar, and ouvkpaors, compofition. 
INTROD. But we have no reafon to think that it can depend altogether upon that

Crap. VI. frame: fince, on the one hand, we fee perfons whofe frame of body is as much alike as can be conceived, differing very confiderably in refpect of their mental frame: and, on the other hand, perfons whofe frame of mind is as much alike as can be conceived, differing very confoicuounly in regard to their bodily frame ${ }^{k}$.

\section{XXXI.}

-and from all others.

It feems indifputable alfo, that the different fets of external occurrences that may befal a man in the courfe of his life, will make great differences in the fubfequent texture of his mind at any. given period: yet ftill thofe differences are not folely to be attributed to fuch occurrences. Fqually far from the truth feems that opinion to be (if any fuch be maintained) which attributes all to nature, and that which attributes all to education. The two circumfances will therefore ftill remain diftinct, as well from one another, as from all others.

\section{XXXII.}

Yet the refult of them is not feparately dilcernible.

Diftinct however as they are, it is manifeft, that at no period in the active part of a man's life can they either of them make their appearance by themfelves. All they do is to conftitute the latent groundwork which the other fupervening circumitances have to work upon: and whatever influence thofe original principles may have, is fo changed and modified, and covered over, as it were, by thofe other circumftances, as never to be feparately difcernible. The effects of the one influence are indiftinguinhably blended with thofe of the other.

x Thofe who maintain, that the mind and the body are one fubftance, may here object, that upon that fuppofition the diftinction between frame of mind and frame of body is but nominal, and that accordingly there is no fuch thing as a frame of mind ditinct from the frame of body. But granting, for argument-fake, the antecedent, we may difpute the confequence. For if the mind be but a part of the body, it is at any rate of a nature very different from the other parts of the body.

A man's frame of body cannot in any part of it undergo any confiderable alteration without its boing immediately indicated by phxnomena difcernible by the fenfes. A man's frame of mind may undergo very confiderable alterations, his frame of body remaining the fame to all appearance; that is, for any thing that is indicated to the contrary by phenomena cognizable to the fenfes : meaning thofe of other men.

XXXIII. The 
XXXIII.

INTROD.

The emotions of the body are received, and with reafon, as probable indications of the temperature of the mind. But they are far enough from conclufive. A man may exhibit, for inftance, the exterior appearances of grief, without really grieving at all, or at leaft in any thing near the proportion in which he appears to grieve. Oliver CHAP. VI. Frame of body indicates, but not Cromwell, whofe conduct indicated a heart more than ordinarily calcertainly, that of mind. lous, was as remarkably profufe in tears *. ' Many men can command the external appearances of fenfibility with very little real feeling. The female fex commonly with greater facility than the male: hence the proverbial expreffion of a woman's tears. To have this kird of command over one's felf, was the characteriftic excellence of the orator of antient times, and is ftill that of the player in our own.

\section{* Hume's hift.}

1 The quantity of the fort of pain, which is called grief, is indeed hardly to be meafured by any external indications. It is neither to be meafured, for inftance, by the quantity of the tears, nor by the number of moments fpent in crying. Indications rather lefs equivocal may, perhaps, be afforded by the pulfe. A man has not the motions of his heart at command as he has thofe of the mufcles of his face. But the particular fignificancy of thefe indications is ftill very uncertain. All they can exprefs is, that the man is affected; they cannot exprefs in what manner, nor from what caufe. To an affection refulting in reality from fuch or fuch a caufe, he may give an artificial colouring, and attribute it to fuch or fuch another caufe. To an affection direeted in reality to fuch or fuch a perfon as its object, he may give an artificial bias, and reprefent it as if directed to fuch or fuch another object. Tears of rage he may attribute to contrition. The concern he feels at the thoughts of a punifhment that awaits him, he may impute to a fympathetic concern for the mifchief produced by his offence.

A very tolerable judgment, however, may commonly be formed by a difcerning mind, upon laying all the external indications exhibited by a man together, and at the fame time comparing them with his actions.

A remarkable infance of the power of the will, over the external indications of fenfibility, is to be found in Tacitus's ftory of the Roman foldier, who raifed a mutiny in the camp, pretending to have loft a brother by the lawlefs cruelty of the General. The truth was, he never had had a brother. 
CH M. VI. The remaining circumftances may, with reference to thofe already

Secondary influencing

circum-

flances. mentioned, be termed fecondary influencing circumftances. Thefe have an influence, it is true, on the quantum or bias of a man's fenfibility, but it is only by means of the other primary ones. The manner in which thefe two fets of circumftances are concerned, is fuch that the primary ones do the bufinefs, while the fecondary ones lie moft open to obfervation. The fecondary ones, therefore, are thofe which are molt heard of ; on which account it will be neceffary to take notice of them : at the fame time that it is only by means of the primary ones that their influence can be explained; whereas the influence of the primary ones will be apparent enough, without any mention of the fecondary ones.

\section{XXXV.}

25. Sex. 25. Among fuch of the primitive modifications of the corporeal frame as may appear to influence the quantum and bias of fenfibility, the moft obvious and confpicuous are thofe, which conftitute the fex. In point of quantity, the fenfibility of the female fex appears in general to be greater than that of the male. The health of the female is more delicate than that of the male: in point of ftrength and hardinefs of body, in point of quantity and quality of knowledge, in point of ftrength of intellectual powers, and firmnefs of mind, the is commonly inferior: moral, religious, fympathetic, and antipathetic fenfibility are commonly ftronger in her than in the male. The quality of her knowledge, and the bent of her inclinations, are commonly in many refpects different. Her moral biafes are alfo, in certain refpects, remarkably different: chatity, modefty, and delicacy, for inftance, are prized more than courage in a woman : courage, more than any of thofe qualities, in a man. The religious biafes in the two fexes are not apt to be remarkably different; except that the female is rather more inclined than the male to fuperftition; that is, to obfervances not dictated by the principle of utility; a difference that may be pretty well accounted for by fome of the before-mentioned circumftances. Her fympathetic biafes arc in many refpects different : for her own offspring all

their 
their lives long, and for children in general while young, her affection INTROD. is commonly ftronger than that of the male. Her affections are apt to CHap. VI. be lefs enlarged: feldom expanding themfelves fo much as to take in the welfare of her country in general, much lefs that of mankind, or the whole fenfitive creation: feldom embracing any extenfive clafs or divifion, even of her own countrymen, unlefs it be in virtue of her fympathy for fome particular individuals that belong to it. In general, her antipathetic, as well as fympathetic biafes, are apt to be lefs conformable to the principle of utility than thofe of the male; owing chiefly to fome deficiency in point of knowledge, difcernment, and comprehenfion. Her habitual occupations of the amufing kind are apt to be in many refpeets different from thofe of the male. With regard to her connections in the way of fympathy, there can be no difference. In point of pecuniary circumftances, according to the cuttoms of perhaps all countries, the is in general lefs independent.

\section{XXXVI.}

26. Age is of courfe divided into divers periods, of which the num- 26. Age. ber and limits are by no means uniformly afcertained. One might diftinguifh it; for the prefent purpofe, into, 1. Infancy. 2. Adolefcence. 3. Youth. 4. Maturity. 5. Decline. 6. Decrepitude. It were lort time to ftop on the prefent occafion to examine it at each period, and to abferve the indications it gives, with refpect to the feveral primary circumftances juft reviewed. Infancy and decrepitude are commonly inferior to the other periods, in point of health, ftrength, hardinefs, and fo forth. In infancy, on the part of the female, the imperfections of that fex are enhanced: on the part of the male, imperfections take place moftly fimilar in quality, but greater in quantity, to thofe attending the ftates of adolefcence, youth, and maturity in the female. In the ftage of decrepitude both fexes relapfe into many of the imperfections of infancy. The generality of thefe obfervations may eafily be corrected upon a particular review.

\section{XXXVII.}

27. Station, or rank in life, is a circumftance, that, among a civilized 27. Rank. people, will commonly undergo a multiplicity of variations. Cateris Vou. I. 
INTROD. paribus, the quantum of fenfibility appears to be greater in the higher CHAP. VI: ranks of men than in the lower. The primary circumftances in refpect of which this fecondary circumftance is apt to induce or indicate a difference, 'feem principally to be as follows: 1. Quantity and Quality of knowledge. 2. Strength of mind. 3. Bent of inclination. 4. Moral fenfibility. 5. Moral biafes. 6. Religious fenfibility. 7. Religious biafes. 8. Sympathetic fenfibility. 9. Sympathetic biafes. 10. Antipathetic fenfibility. I1. Antipathetic biafes. I2. Habitual occupations. 13. Nature and produetivenefs of a man's means of livelihood. 14. Connections importing profit. 15. Habit of expence. 16. Connections importing burthen. A man of a certain rank will frequently have a number of dependents befides thofe whofe dependency is the refult of natural relationhip. As to health, ftrength, and hardinefs, if rank has any influence on thefe circumitances, it is but in a remote way, chiefly by the influence it may have on his habitual occupations.

\section{XXXVIII.}

28. Education.

28. The influence of education is ftill more extenfive. Education ftands upon a footing fomewhat different from that of the circumftances of age, fex, and rank. Thefe words, though the influence of the circumftances they refpectively dernote exerts itfelf principally, if not entirely, through the medium of certain of the primary circumftances before-mentioned, prefent, however, each of them a circumftance which has a feparate exiftence of itfelf. This is not the cafe with the word education: which means nothing any farther than as it ferves to call up to view fome one or more of thofe primary circumftances. Education may be diftinguifhed into phyfical and mental; the education of the body and that of the mind: mental, again, into intellectual and moral; the culture of the underftanding; and the culture of the affections. The education a man receives, is given to him partly by others, partly by himfelf. By education then nothing more can be expreffed than the condition a man is in in refpect of thofe primary circumftances, as refulting partly from the management and contrivance of others, principally of thofe who in the early periods of 
his life have had dominion over him, partly from his own. To the phyfical part of his education, belong the circumftances of health, ftrength, and hardinefs : fometimes, by accident, that of bodily imperfection; as where by intemperance or negligence an irreparable mifchief happens to his perfon. To the intellectual part, thofe of quantity and quality of knowledge, and in fome meafure perhaps thofe of firmnefs of mind and fteadinefs. To the moral part, the bent of his inclinations, the quantity and quality of his moral, religious, fympathetic, and antipathetic fenfibility: to all three branches indifcriminately, but under the fuperior controul of external occurrences, his habitual recreations, his property, his means of livelihood, his connections in the way of profit and of burthen, and his habits of expence. With refpect indeed to all thefe points, the influence of education is modified, in a manner more or lefs apparent, by that of exterior occurrences; and in a manner fearcely at all apparent, and altogether out of the reach of calculation, by the original texture and conftitution as well of his body as of his mind.

\section{XXXIX.}

29. Among the external circumftances by which the influence of edu- 29. Climate. cation is modified, the principal are thofe which come under the head of climate. This circumftance places itfelf in front, and demands a feparate denomination, not merely on account of the magnitude of its influence, but alfo on account of its being confpicuous to every body, and of its applying indifcriminately to great numbers at a time. This circumftance depends for its effence upon the fituation of that part of the earth which is in queftion, with refpect to the courfe taken by the whole planet in its revolution round the fun : but for its infuence it depends upon the condition of the bodies which compofe the earth's furface at that part, principally upon the quantities of fenfible heat at different periods, and upon the denfity, and purity, and drynefs or moifture of the circumambient air. Of the fo often mentioned primary circumftances, there are few of which the production is not influenced by this fecondary one; partly by its manifeft effects upon the body; partly by its lefs perceptible effects upon the mind. In hot climates

$$
\text { I } 2^{\circ} \text { men's }
$$


INTROD. men's health is apt to be more precarious than in cold : their ftrength Crar. VI. and hardinefs lefs : their vigour, firmnefs, and teadinefs of mind lefs : and thence indirectly their quantity of knowledge: the bent of their inclinations different : moft remarkably fo in refpect of their fuperior propenfity to venereal enjoyments, and in refpect of the earlinefs of the period at which that propenfity begins to manifeft itfelf: their fenfibilities. of all kinds more intenfe: their habitual occupations favouring more of noth than of activity: their radical frame of body lefs ftrong, probably, and lefs hardy; their radical frame of mind lefs vigorous, lefs firm, lefs fteady.

XL.

30. Lineage. 30. Another article in the catalogue of fecondary circumftances, is that of race or lineage: the national race or lineage a man iffues from. This: circumftance, independently of that of climate, will commonly make fome difference in point of radical frame of mind and body. A man of negro race, born in France or England, is a very different being, in: many refpects, from a man of French or Englifh race. A man of Spanin. race, born in Mexico or Peru, is at the hour of his birth a different fort of being, in many refpects, from a man of the original Mexican or Peruvian race. This circumftance, as far as it is diftinet from climate, rank, and education, and from the two juft mentioned, operates chiefly: through the medium of moral, religious, fympathetic, and antipathetic biafes.

XLI.

31. Govern-
ment. ment a man lives under at the time in queftion; or rather that under. which he has been accuftomed mort to live. This circumftance ope-. rates principally through the medium of education: the magiftrate. operating in the character of a tutor upon all the members of the ftate, by the direction he gives to their hopes and to their fears. Indeed. under a folicitous and attentive government, the ordinary preceptor, nay even the parent himfelf, is but a deputy, as.it were, to the magiArate: whofe controuling influence, different in this refpect from that of the ordinary preceptor, dwells with a man to his life's end. The effects. of the peculiar power of the magiftrate are feen more particularly in the influence 


\section{Of Circumftances influencing [S E N S I B I L I T Y.]}

influence it exerts over the quantum and bias of men's moral, religious, fympathetic, and antipathetic fenfibilities. Under a well-conftituted, INTROD. or even under a well-adminiftered though ill-conftituted government, men's moral fenfibility is commonly ftronger, and their moral biafes more conformable to the dictates of utility: their religious fenfibility frequently weaker, but their religious biafes lefs unconformable to the dictates of utility: their fympathetic affections more enlarged, directed to the magiftrate more than to fmall parties or to individuals, and more to the whole community than to either: their antipathetic fenfibilities lefs violent, as being more obfequious to the influence of welldirected moral biafes, and lefs apt to be excited by that of ill-directed religious ones: their antipathetic biafes more conformable to welldirected moral ones, more apt (in proportion) to be grounded on enlarged and fympathetic than on narrow and felf-regarding affections, and accordingly, upon the whole, more conformable to the dictates of atility.

\section{XLH.}

32. The laft circumftance is that of religious profeffion: the re- 3 a. Religious ligious profeffion a man is of: the religious fraternity of which he is a member. This circumftance operates principally through the medium of religious fenfibility and religious biafes. It operates, however, as an indication more or lefs conclufive, with refpect to feveral other circumftances. With refpect to fome, fcarcely but through the medium of the two juft mentioned: this is the cafe with regard to the quantum and bias of a man's moral, fympathetic, and antipathetic fenfibility : perhaps in fome cafes with regard to quantity and quality of knowledge, ftrength of intellectual powers, and bent of inclination. With: refpect to others, it may operate immediately of itfelf: this feems to be the cafe with regard to a man's habitual occupations, pecuniary circumftances, and connections in the way of fympathy and antipathy. A man who pays very little inward regard to the dictates of the religion which he finds it neceffary to profefs, may find it difficult to avoid joining in the ceremonies of it, and bearing a part in the pecuniary burthens it im- 
INTROD. pofes ${ }^{m}$. By the force of habit and example he may even be led to CнAт. VI. entertain a partiality for perfons of the fame profeffion, and a proportionable antipathy againt thofe of a rival one. In particular, the antipathy againt perfons of different perfuafions is one of the laft points of religion which men part with. Laftly, it is obvious, that the religious profefion a man is of cannot but have a confiderable influence on his education. But, confidering the import of the term education, to fay this is perhaps no more than faying in other words what has been faid already.

\section{XLIII.}

Ule of the preceding obfervations.

Thefe circumftances, all or many of them, will need to be attended to as often as upon any occafion any account is taken of any quantity of pain or pleafure, as refulting from any caufe. Has any perfon fuftained an injury? they will need to be confidered in eftimating the mifchief of the offence. Is fatisfaction to be made to him? they will need to be attended to in adjufting the quantum of that fatisfaction. Is the injurer to be punifhed? they will need to be attended to in eftimating the force of the impreffion that will be made on him by any given punifhment.

\section{XLIV.}

How far the It is to be obferved, that though they feem all of them, on fome circum-

ftances in

queftion can

be taken into

account. account or other, to merit a place in the catalogue, they are not all of equal ufe in practice. Different articles among them are applicable to different exciting caures. Of thofe that may influence the effect of the fame exciting caufe, fome apply indifcriminately to whole claffes of perfons together; being applicable to all, without any remarkable difference in degree: theie may be direçtly and pretty fully

$m$ The ways in which a religion may lefen a man's means, or augment his wants, are various. Sometimes it will prevent him from making a profit of his money : fometimes from fetting his hand to labour. Sometimes it will oblige him to buy dearer food inftead of cheaper : fometimes to purchafe urelers labour: fometimes to pay men for not labouring: fometimes to purchafe trinkets, on which imagination alone has fet a value : fometimes to purchafe exemptions from punifhment, or titles to felicity in the world to come. 


\section{of Circumfances infuencing [S E N S I B I L I T Y.]}

Ixiii

provided for by the leginator. This is the cafe, for inffance, with the primary circumftances of bodily imperfection, and infanity: with the fecondary circumftance of fex : perhaps with that of age : at any rate with thofe of rank, of climate, of lineage, and of religious profeffion. Others, however they may apply to whole claffes of perfons, yet in their application to different individuals are fufceptible of perhaps an indefinite variety of degrees. Thefe cannot be fully provided for by the leginator; but, as the exiftence of them, in every fort of cafe, is capable of being afcertained, and the degree in which they take place is capable of being meafured, provifion may be made for them by the judge, or other executive magiftrate, to whom the feveral individuals that happen to be concerned may be made known. This is the cafe, 1 . With the circumftance of health. 2. In fome fort with that of ftrength. 3. Scarcely with that of hardinefs : ftill lefs with thofe of quantity and quality of knowledge, ftrength of intellectual powers, firmnefs or fteadinefs of mind; except in as far as a man's condition, in refpect of thofe circumftances, may be indicated by the fecondary circumftances of fex, age, or rank : hardly with that of bent of inclination, except in as far as that latent circumftance is indicated by the more manifent one of habitual occupations: hardly. with that of a man's moral fenfibility or biafes, except in as far as they may be indicated by his fex, age, rank, and education : not at all with his religious fenfibility and religious biafes, except in as far as they may be indicated by the religious profeffion he belongs to: not at all with the quantity or quality of his fympathetic or antipathetic fenfibilities, except in as far as they may be prefumed from his fex, age, rank, education, lineage, or religious profeffion. It is the cafe, however, with his habitual occupations, with his pecuniary circumftances, and with his connections in the way of fympathy. Of others, again, either the exiftence cannot be afcertained, or the degree cannot be meafured. Thefe, therefore, cannot be taken into account, either by the leginator or the executive magiftrate. Accordingly, they would have no claim to be taken notice of, were it not for thofe fecondary circumftances by which they are indicated, and whofe infuence could not well be underftood without them. What thefe are has been already mentioned. 
XLV.

Crap. VI. It has already been obferved, that different articles in this lift of To what ex- circumftances apply to different exciting caufes: the circumftance of citing caufes bodily itrength, for inftance, has fcarcely any influence of itfelf (what-
there is molt occafion to apply them. ever it may have in a roundabout way, and by accident) on the effeet of an incident which fhould encreafe or diminith the quantum of a man's property. It remains to be confidered, what the exciting caufes are with which the leginator has to do. Thefe may, by fome accident or ather, be any whatfoever: but thofe with which he has principally to do, are thofe of the painful or aftlictive kind. With pleafurable ones he has little to do, except now and then by accident: the reafons of which may be eafily enough perceived, at the fame time that it would take up too much room to unfold them here. The exciting caufes with which he bas principally to do, are, on the one hand, the mifchievous acts, which it his bufinefs to prevent; on the other hand, the punifhments, by the terror of which it is his endeavour to prevent them. Now of thefe two fets of exciting caufes, the latter only is of his production: being produced partly by his own fpecial appointment, partly in conformity to his general appointment, by the fpecial appointment of the judge. For the leginator, therefore, as well as for the judge, it is neceffary (if they would know what it is they are doing when they are appointing punifhment) to have an eye to all thefe circumftances. For the legillator, left, meaning to apply a certain quantity of punifhment to all perfons who thall put themfelves in a given predicament, he thould unawares apply to fome of thofe perfons much more or much lefs than he himfelf intended: for the judge, left, in applying to a particular perfon a particular meafure of punifhment, he fhould apply much more or much lefs than was intended, perhaps by himfelf, and at any rate by the leginator. They ought cach of them, therefore, to have before him, on the one hand, a lift of the feveral circumftances by which fenfibility may be influenced; on the other hand, a lift of the feveral fpecies and degrees of punifhment which they purpofe to make ufe of: and then, by making a comparifon between the two, to form a detailed eftimate of the influence of each of the circumftances in quertion, upon the effect of each fpecies and degree of punifhment. 
There are two plans or orders of diftribution, either of which might be purfued in the drawing up this eftimate. The one is to make the name of the circumftance take the lead, and under it to reprefent the different influences it exerts over the effects of the feveral modes of punifhment: the other is to make the name of the punifhment take the lead, and under it to reprefent the different influences which are exerted over the effeets of it by the feveral circumftances above-mentioned. Now of thefe two forts of objects, the punifhment is that to which the intention of the legilator is directed in the firft inftance. This is of his own creation, and will be whatfoever he thinks fit to make it : the influencing circumftance exifts independently of him, and is what it is whether he will or no. What he has occafion to do is to eftablinh a certain fpecies and degree of punifhment: and it is only with reference to that punifhment that he has occafion to make any enquiry concerning any of the circumftances here in queftion. The latter of the two plans therefore is that which appears by far the mort ufeful and commodious. But neither upon the one nor the other plan can any fuch eftimate be delivered here ${ }^{\mathrm{n}}$.

XLVI.

Of the feveral circumftances contained in this catalogue, it may be of ufe to give fome fort of analytic view; in order that it may be the more eafily difcovered if any which ought to have been inferted are

$n$ This is far from being a vifionary propofal, not reducible to practice. I fpeak from experience, having actually drawn up fuch an eftimate, though upon the leaft commodious of the two plans, and before the feveral circumfances in queftion had been reduced to the precife number and order in which they are here enumerated. This is a part of the matter deftined for another work. See ch. xiii. [Cafes unmeet] par. 2. Note. There are fome of thefe circumftances that beftow particular denominations on the perfons they relate to: thus, from the circumftance of bodily imperfections, perfons are denominated deaf, dumb, blind, and fo forth : from the circumAtance of infanity, idiots, and maniacs: from the circumftance of age, infants: for all which claffes of perfons particular provifion is made in the Code. See B. I. tit. [Exemptions.] Perfons thus diftinguifhed will form fo many articles in the catalogus perfonarum privilegiaturum. See Appendix. tit. [Compofition.]

VoL. I. 


\section{lxvi Of Circumfances infuencing [SE N S I BI L I T Y.]}

INTROD. omitted; and that, with regard to thofe which are inferted, it may be CHAP. VI. feen how they differ and agree.

In the firft place, they may be diftinguifhed into primary and fecondary: thofe may be termed primary, which operate immediately of themfelves: thofe fecondary, which operate not but by the medium of the former. To this latter head belong the circumftances of fex, age, ftation in life, education, climate, lineage, government, and religious profeffion: the reft are primary. Thefe again are either connate or adventitious: thofe which are connate, are radical frame of body and radical frame of mind. Thofe which are adventitious, are either perfonal, or exterior. The perfonal, again, concern either a man's dijpofitions, or his actions. 'Thofe which concern his difpofitions, concern either his body or his mind. Thofe which concern his body are health, ftrength, hardinefs, and bodily imperfection. Thofe which concern his mind, again, concern either his usderftanding or his affections. To the former head belong the circumftances of quantity and quality of knowledge, ftrength of underftanding, and infanity. To the latter belong the circumftances of firmners of mind, fteadinefs, bent of inclination, moral fenfibility, moral biafes, religious fenfibility, religious biafes, fympathetic fenfibility, fympathetic biafes, antipathetic fenfibility, and antipathetic biafes. Thofe which regard his actions, are his habitual occupations. Thofe which are exterior to him, regard either the things or the perfons which he is concerned with; under the former head come his pecuniary circumftances ${ }^{\circ}$; under the latter, his connections in the way of fympathy: and antipathy.

- As to a man's pecuniary circumftances, the caufes on which thofe circumftances depend, do not come all of them under the fame clafs. The abfolute quantum of a man's property does indeed come under the fame clais with his pecuniary circun ftances in general: fo does the profit he makes from the occupation which furnifhes him with the means of livelihood. But the occupation itfelf concerns his own perfon, and comes under the fame head as his habitual amufements : as likewife his. habits of expence : his connections in the ways of profit and of burthen, under the fame head as his connections in the way of fympathy: and the circumftances of his prefent demand for money, and ftrength of expectation, come under the head of thofe circumfances relative to his perfon which regard his affections, 


\section{C $\mathrm{H}$ A P. VII.}

I.

$7 \mathrm{HE}$ bufinefs of government is to promote the happinefs of the fociety, by punifhing and rewarding. That part of its bufinefs which confifts in punifhing, is more particularly the fubject of penal law. In proportion as an act tends to difturb that happinefs, in proportion as the tendency of it is pernicious, will be the demand it creates for punifhment. What happinefs confifts of we have already feen : en- of the act. joyment of pleafures, fecurity from pains.

II.

The general tendency of an act is more or lefs pernicious, according Tendency of to the fum total of its confequences: that is, according to the dif- an act deterference between the fum of fuch as are good, and the fum of fuch as confequences. are evil.

III.

It is to be obferved, that here, as well as henceforward, wherever confequences are fpoken of, fuch only are meant as are material. Of the confequences of any act, the multitude and variety muft needs be infinite: but fuch of them only as are material are worth regarding. INTROD. CHAP. VIr. The demand for puninment depends in part upon Now among the confequences of an act, be they what they may, fuch only, by one who views them in the capacity of a leginator, can be faid to be material *, as either confift of pain or pleafure, or have an influence in the production of pain or pleafure ${ }^{2}$.

* or of importance.

2 In certain cafes the confequences of an act may be material by ferving as evidences indicating the exiftence of fome other material faet, which is even antecedent to the act of which they are the confequences: but even here, they are material only becaufe, in virtue of fuch their evidentiary quality, they have an influence, at a fubfe. quent period of time, in the production of pain and pleafure: for example, by ferva. ing as grounds for conviction, and thence for punifhment. See tit. [Simple Falloods.] verbo [material.]
$\mathrm{K}_{2}$
IV. It 
INTROD. Chap.VII. Thefe depend in part upon the in. tention.
IV.

It is alfo to be obferved, that into the account of the confequences of the act, are to be taken not fuch only as might have enfued, were intention out of the queftion, but fuch alfo as depend upon the connection there may be between thefe firft-mentioned confequences and the intention. The connection there is between the intention and certain confequences is, as we thall fee hereafter*, a means of producing other confequences. In this lies the difference between rational agency and irrational.

$\mathrm{V}$.

The intention depends as well upon the underftanding as the will.

Now the intention, with regard to the confequences of an act, will depend upon two things : $x$. The ftate of the will or intention, with refpect to the act itfelf. And, 2. The ftate of the underftanding, or perceptive faculties, with regard to the circumftances which it is, or may appear to be, accompanied with. Now with refpect to thefe circumftances, the perceptive faculty is fufceptible of three ftates : confcioufnefs, unconfcioufnefs, and falfe confcioufnefs. Confcioufnefs, when the party believes precifely thofe circumftances, and no others, to fubfift, which really do fubfift : unconfcioufnefs, when he fails of perceiving certain circumftances to fubfift, which, however, do fubfift: falfe confcioufnefs, when he believes or imagines certain circumftances, to fubfift, which in truth do not fubfift.

VI.

In an action In every tranfaction, therefore, which is examined with a view to: are to be con fidered,

1. The ad.

2. The cir-

cumftances.

3. The intentionality.

4. The confcioulnefs.

5. The motives. 6. The difpoftion. punifhment, there are four articles to be confidered:. I. The aEt itfelf, which is done. 2. The circumftances in which it is done. 3. The intentionality that may have accompanied it. 4. The confcioufness, unconfcioufnefs, or falfe confcioufnefs, that may have accompanied it.

What regards the act and the circumitances will be the fubject of the prefent chapter: what regards intention and confcioufnefs, that of the two fucceeding.

VII.

There are alfo two other articles on which the general tendency of

- See B. I. tit. [Exemptions] and tit. [Extenuations.] 
an act depends : and on that, as well as on other accounts, the demand which it creates for puninment. Thefe are, I. The particular motive INTROD. or motives. which gave birth to it. 2. The general difpofition which it indicates. Thefe articles will be the fubject of two other chapters.

VIII.

Acts may be diftinguifhed in feveral ways, for feveral purpofes.

They may be diftinguifhed, in the firft place, into pofitive and neCHAP. VII. gative. By pofitive are meant fuch as confift in motion or exertion: by negative, fuch as confift in keeping at reft; that is, in forbearing to move or exert one's, felf in fuch and fuch circumftances. Thus, to ftrike is a pofitive act: not to ftrike on a certain occafion, a negative one. Pofitive acts are ftiled alfo acts of commiffion; negative, acts of omiffion or forbearance ${ }^{b}$.

\section{IX.}

Such acts, again, as are negative, may either be abfolutely fo, or re- Negative ats latively: abfolutely, when they import the negation of all pofitive maybe fo reagency whatfoever; for inftance, not to ftrike at all : relatively, when folutely. they import the negation of fuch or fuch a particular mode of agency; for inftance, not to ftrike fuch a perfon or. fuch a thing, or in fuch a direction.

b The diftinction between pofitive and negative acts runs through the whole. fyltem of offences, and fometimes makes a material difference with regard to their confequences. To reconcile us the better to the extenfive, and, as it may appear on fome occafions, the inconfiftent fignification here given to the word $a \mathbb{E}$, it may be confidered, 1. That in many cafes, where no exterior or overt act is exercifed, the ftate which the mind is in at the time when the fuppofed act is faid to happen, is as truly and directly the refult of the will, as any exterior act, how plain and confpicuous foever. The not revealing a confpiracy, for inftance, may be as perfectly the act of the will, as the joining in it. In the next place, that even though the mind thould never have had the incident in queftion in contemplation (infomuch that the event of its not happening thould not have been fo much as obliquely intentional) ftill the ftate the perfon's mind was in at the time when, if he bad fo willed, the incident might have happened, is in many cafes productive of as material confequences; and not only as likely, but as fit to call for the interpofition of other agents, as the oppofite one. Thus, when a tax. is impofed, your not paying it is an aet which at any rate muft be punifhed in a certain manner, whether you happened to think of paying it or not. 
INTROD. Crap. VII. Negative acts may be exprefred po fitively; and vice ver $\int a$.

\section{$\mathrm{X}$.}

It is to be obferved, that the nature of the act, whether pofitive or negative, is not to be determined immediately by the form of the difcourfe made ufe of to exprefs it. An act which is pofitive in its nature may be characterized by a negative expreffion: thus, not to be at reft, is as much as to fay to move. So alfo an act, which is negative in its nature, may be characterized by a pofitive expreffion: thus, to forbear or omit to bring food to a perfon in certain circumftances, is fignified by the fingle and pofitive term to ftarve.

$\mathrm{XI}$.

Acts external In the fecond place, acts may be diftinguifhed into external and inand internal. ternal. By external, are meant corporal acts; acts of the body: by internal, mental acts; acts of the mind. Thus, to ftrike is an external or exterior ${ }^{c}$ act : to intend to ftrike, an internal or interior one.

\section{XII.}

Acts of difcourfe, what.

Acts of difcourfe are a fort of mixture of the two: external acts, which are no ways material, nor attended with any confequences, any farther than as they ferye to exprefs the exiftence of internal ones. To fpeak to another to ftrike, to write to him to ftrike, to make figns to him to ftrike, are all fo many acts of difcourfe.

\section{XIII.}

External acts may be tranfive or intranfitive.

Thirdly, Acts that are external may be diftinguifhed into tranfitive and intranfitive. Aats may be called tranfitive, when the motion is communicated from the perfon of the agent to fome foreign body: that is, to fuch a foreign body on which the effects of it are confidered as being material; as where a man runs againft you, or throws water in your face. Acts may be called intranfitive, when the motion is communicated to no other body, on which the effects of it are regarded as material, than fome part of the fame perfon in whom it originated : as where a man runs, or wafhes himfelf ${ }^{\mathrm{d}}$.

XIV. An

- [Exterior.] An exterior act is alfo called by lawyers overt.

Diftinction be-

tween tranfitive

tive, recognized

- The diftinction is well known to the latter grammarians: it is with them indeed that it took its rife: though by them it has been applied rather to the names than to by grammarians. 
An act of the tranfitive kind may be faid to be in its commencement, or in the firft ftage of its progrefs, while the motion is confined to the perfon of the agent, and has not yet been communicated to any foreign body, on which the effects of it can be material. It may be faid to be in its termination, or to be in the laft ftage of its progrefs, as foon as the motion or impulfe has been communicated to Chap, VII. act, its commencement, termination, and interme. fome fuch foreign body. It may be faid to be in the middle or intermediate ftage or ftages of its progrefs, while the motion, having paffed from the perfon of the agent, has not yet been communicated to any fuch foreign body. Thus, as foon as a man has lifted up his hand to ftrike, the act he performs in ftriking you is in its commencement : as foon as his hand has reached you, it is in its termination. If the act be the motion of a body which is feparated from the perfon of the agent before it reaches the object, it may be faid, during that interval, to be in its intermediate progrefs *, or in gradu mediativo: as in the cafe where a man throws a ftone or fires a bullet at you.

$\mathrm{XV}$.

An act of the intranfitive kind may be faid to be in its commencement, when the motion or impulfe is as yet confined to the member or organ in which it originated; and has not yet been communicated to any member or organ that is diftinguifhable from the diate progrefs. former. It may be faid to be in its termination, as foon as it has been applied to any other part of the fame perfon. Thus, where a man poifons himfelf, while he is lifting up the poifon to his mouth, the

the things themfelves. To verbs, fignifying tranfitive acts, as here defcribed, they have given the name of tranfitive verbs: thofe fignificative of intranfitive acts they have termed intranfitive. Thefe lalt are ftill more frequently called neuter; that is, neither active nor pafive. The appellation feems improper : fince, inftead of their being neitber, they are both in one.

To the clafs of acts that are here termed intranfitive, belong thofe which conftitute the $3 \mathrm{~d}$ clafs in the fyftem of offences. See ch. [Divifion.] and B. 1. tit. [Self-regarding Offences:]

- or in its migration, or in tranfitu.

An intranfitive act, its commencement, and termination. 
INTROD. act is in its commencement : as foon as it has reached his lips, it is in Chap. VII. its termination ${ }^{e}$.

XVI.

Acts tranfient In the third place, acts may be diftinguifhed into tranfient and conand continu- tinued. Thus, to ftrike is a tranfient act: to lean, a continued one. To buy, tranfient act: to keep in one's poffeffion, a continued one.

XVII.

Difference In ftrictnefs of fpeech there is a difference between a continued act continued act and a repetition of acts. It is a repetition of acts, when there are inand a repeti- tervals filled up by acts of different natures: a continued act, when tion of acts. there are no fuch intervals. Thus, to lean, is one continued act: to keep ftriking, a repetition of acts.

XVIII.

Difference There is a difference, again, between a repetition of acts, and a babit

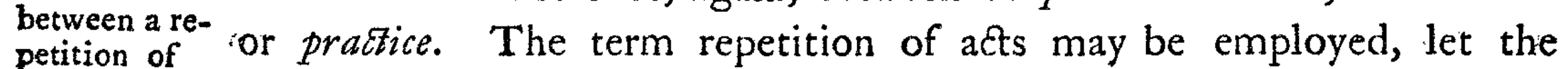
acts and a acts in queftion be feparated by ever fuch hort intervals, and let the habit. fum total of them occupy ever fo hort a fpace of time. The term habit is not employed but when the acts in queftion are fuppofed to be feparated by long-continued intervals, and the fum total of them to occupy a confiderable fpace of time. It is not (for inftance) the drinking ever fo many times, nor ever fo much at a time, in the courfe of the fame fitting, that will conftitute a habit of drunkennefs : it is neceffary that fuch fittings themfelves be frequently repeated. Every habit is a repetition of acts; or, to fpeak more ftrictly, when a man has frequently repeated fuch and fuch acts after confiderable intervals, he is faid to have perfevered in or contracted a habit: but every repetition of acts is not a habit ${ }^{\mathrm{f}}$.

- Thefe diftinetions will be referred to in the next chapter: ch. viii. [Intentionality] : and applied to practice in B. I. tit. [Extenuations.]

${ }^{f}$ [Habit.] A habit, it thould feem, can hardly in ftricnefs be termed an aggregate of acts : acts being a fort of real archetypal entities, and habits a kind of fictitious entities or imaginary beings, fuppofed to be conftituted by, or to refult as it were out of, the former.

XIX. Fourthly, 


\section{XIX.}

Fourthly, acts may be diftinguifhed into indivifible and divifible. Indivifible acts are merely imaginary : they may be eafily conceived, but can never be known to be exemplified. Such as are divifible may be fo, with regard either to matter or to motion. An act indivifible, with regard to matter, is the motion or reft of one fingle atom of matter. An act indivifible, with regard to motion, is the motion of any body, from one fingle atom of fpace to the next to it.

$$
\mathrm{XX} \text {. }
$$

It has been every now and then made a queftion, what it is in fuch a cafe that conftitutes one act: where one act has ended, and another act has begun: whether what has happened has been one act or many ${ }^{\mathrm{B}}$. Thefe queftions, it is now evident, may frequently be anfwered, with equal propriety, in oppofite ways : and if there be any occafions on which they can be anfwered only in one way, the anfwer will depend upon the nature of the occafion, and the purpofe for which the queftion is propofed. A man is wounded in two fingers at one ftroke-Is it one wound or feveral? A man is beaten at 12 o'clock, and again at $8 \mathrm{mi}-$ nutes after 12 -Is it one beating or feveral? You beat one man, and inftantly in the fame breath you beat another-Is this one beating or feveral ? In any of thefe cafes it may be one, perhaps, as to fome purpofes, and feveral as to others. Thefe examples are given, that men may be aware of the ambiguity of language : and neither harrafs themfelves with unfolvable doubts, nor one another with interminable difputes.

\section{XXI.}

So much with regard to acts confidered in themfelves: we come circumnow to fpeak of the circumftances with which they may have been ac- ftances are to companied. Thefe muft neceffarily be taken into the account before ed. be confiderany thing can be determined relative to the confequences. What the confequences of an act may be upon the whole can never otherwife be afcertained: it can never be known whether it is beneficial, or indifferent, or mifchievous. In fome circumftances even to

8 Diftinctions like thefe come frequently in queftion in the courfe of Procedure.

VoL. I. 
INTROD. kill a man may be a beneficial act: in others, to fet food before him

CHA . VII. may be a pernicious one.

\section{XXII.}

Circum- Now the circumftances of an act, are, what? Any objects * whatroever. Take any act whatfoever, there is nothing in the nature of things that excludes any imaginable object from being a circumftance to it. Any given object may be a circumftance to any other ${ }^{\text {h }}$.

XXIII.

Circum- We have already had occafion to make mention for a moment of ftances mate-
rial and immaterial. immaterial. In like manner may the circumftances of it be diftinguifhed. Now materiality is a relative term: applied to the confequences of an act, it bore relation to pain and pleafure : applied to the circumftances, it bears relation to the confequences. A circumftance may be faid to be material, when it bears a vifible relation in point of caufality to the confequences: immaterial, when it bears no fuch vifible relation.

A circumAance may be related to an eventin point
of caufality, of caufality viz. 1. Production. 2. Derivation. 3. Collateral connection. 4. Conjunet influence.

Circumftance, archetypation of

XXIV.

The confequences of an act are events $\dagger$. A circumfance may be related to an event in point of caufality in any one of four ways : 1 . In the way of caufation or production. 2. In the way of derivation. 3. In the way of collateral connection. 4. In the way of conjunet influence. It may be faid to be related to the event in the way of caufation, when it is of the number of thofe that contribute to the production of fuch event: in the way of derivation, when it is of

* or entities. See B. II. tit. [Evidence.] \& [Facts.]

h The etymology of the word circumftance is perfectly characteriftic of its import: circum fantia, things ftanding round : objects ftanding round a given object. I forget what mathematician it was that defined God to be a circie, of which the centcr is every where, but the circumference no where. In like manner the field of circumftances, belonging to any act, may be defined a circle, of which the circumference is no where, but of which the act in queftion is the center. Now then, as any act may, for the purpofe of difcourfe, be confidered as a center, any other act or object whatfoever may be confidered as of the number of thofe that are ftanding round it. + See B. II. tit. [Evidence.] $\$[$ F acts.] 
the number of the events to the production of which that in queftion INTROD. has been contributory: in the way of collateral connection, where the circumftance in queftion, and the event in queftion, without being either of them inftrumental in the production of the other, are related, each of them, to fome common object, which has been concerned in the production of them both: in the way of conjunet influence, when, whether related in any other way or not, they have both of them concurred in the production of fome common confequence.

\section{$\mathrm{XXV}$.}

An example may be of ufe. In the year 1628, Villiers, Duke of Example. Buckingham, favourite and minifter of Charle; I. of England, received Aftafination a wound and died. The man who gave it him was one Felton, who, ham. exafperated at the mal-adminiftration of which that minifter was accufed, went down from London to Portfmouth, where Buckingham happened then to be, made his way into his anti-chamber, and finding him bufly engaged in converfation with a number of people round him, got clofe to him, drew a knife and ntabbed him. In the effort, the affafin's hat fell off, which was found foon after, and, upon fearching him, the bloody knife. In the crown of the hat were found fcraps of paper, with fentences expreffive of the purpofe he was come upon. Here then, fuppofe the event in queftion is the wound received by Buckingham: Felton's drawing out his knife, his making his way into the chamber, his going down to Portfmouth, his conceiving an indignation at the idea of Buckingham's adminiftration, that adminiftration itfelf, Charles's appointing fuch a minifter, and fo on, higher and higher without end, are fo many circumftances, related to the event of Buckingham's receiving the wound, in the way of caufation or production: the bloodinefs of the knife, a circumitance related to the fame event in the way of derivation: the finding of the hat upon the ground, the finding the fentences in the hat, and the writing them, fo many circumftances related to it in the way of collateral connection: and the fituation and converfations of the people about Buckingham, were circumftances related to the circumftances of 
INTROD. Felton's making his way into the room, going down to Portfmouth, CHAr. VII. and fo forth, in the way of conjunct influence; inafmuch as they contributed in common to the event of Buckingham's receiving the wound, by preventing him from putting himfelf upon his guard upon the firit appearance of the intruder ${ }^{\text {. }}$.

\section{XXVI.}

It is not every event that has circum. ftances related to it in all thofe ways.

Thefe feveral relations do not all of them attach upon an event with equal certainty. In the firft place, it is plain, indeed, that every event muft have fome circumftance or other, and in truth, an indefinite multitude of circumftances, related to it in the way of production: it muft of courfe have a ftill greater multitude of circumftances related to it in the way of collateral connection. But it does not appear neceffary that every event thould have circumftances related to it in the way of derivation: nor therefore that it hould have any related to it in the way of conjunt influence. But of the circumftances of all kinds which actually do attach upon an event, it is only a very finall number that can be difcovered by the utmoft exertion of the human faculties : it is a ftill fmaller number that ever actually do attract our notice: when occafion happens, more or fewer of them will be difcovered by a man, in proportion to the ftrength, partly of his intellectual powers, partly of his inclination ${ }^{k}$. It appears therefore that the multitude and defcription

1 The divifion may be farther illuftrated and confirmed by the more fimple and particular cafe of animal generation. To production correfponds paternity: to derivation, filiation : to collateral connection, collateral confanguinity: to conjunct influence, marriage and copulation.

If neceffary, it might be again illuftrated by the material image of a chain, fuch as that which, according to the ingenious fiction of the antients, is attached to the throne of Jupiter. A fection of this chain thould then be exhibited by way of fpecimen, in the manner of the diagram of a pedigree. Such a figure I hould accordingly have exhibited, had it not been for the apprehenfion that an exhibition of this fort, while it made the fubject a fmall matter clearer to one man out of a hundred, might, like the mathematical formularies we fee fometimes employed for the like purpofe, make it more obfcure and formidable for the other ninety-nine.

k The more remote a connection of this fort is, of courfe the more obfcure. It will often happen that a connection, the idea of which would at firft fight appear ex- 
fcription of fuch of the circumftances belonging to an act, as may appear to be material, will be determined by two confiderations: I. By INTROD. the nature of things themfelves. 2. By the ftrength or weaknefs of Chap. VII. the faculties of thofe who happen to confider them.

\section{XXVII.}

Thus much it feemed neceffary to premife in general concerning acts, and their circumitances, previoully to the confideration of the particular forts of acts with their particular circumftances, with which we thall have to do in the body of the work. An act of fome fort or other is neceffarily included in the notion of every offence. Together with this act, under the notion of the fame offence, are included certain circumftances: which circumftances enter into the effence of the offence, contribute by their conjunct influence to the production of its confequences, and in conjunction with the act are brought into view by the name by which it ftands diftinguifhed. Thefe we hall have occafion to diftinguin hereafter by the name of criminative circumftances*. Other circumftances again entering into combination with the act and the former fet of circumftances, are productive of ftill farther confequences. Thefe additional confequences, if they are

travagant and abfurd, thall be rendered highly probable, and indeed indifputable, merely by the fuggeftion of a few intermediate circumftances.

At Rome, 390 years before the Chriftian æra, a goofe fets up a cackling: two thoufand years afterwards a king of France is murdered. To confider thefe two events, and nothing more, what can appear more extravagant than the notion that the former of them fhould have had any influence on the production of the latter? Fill up the gap, bring to mind a few intermediate circumftances, and nothing can appear more probable. It was the cackling of a parcel of geefe, at the time the Gauls had furprized the Capitol, that faved the Roman commonwealth: had it not been for the afcendancy that commonwealth acquired afterwards over moft of the nations of Eurrope, amongft others over France, the Chriftian religion, humanly fpeaking, could not have eftablifhed itfelf in the manner it did in that country. Grant then, that fuch a man as Henry IV. would have exifted, no man, however, would have had thofe motives, by which Ravaillac, milled by a mifchievous notion concerning the didates of that religion, was prompted to affaftnate him.

- See B. I. tit. [Crim. circumftances.]

Ufe of this chapter. 
INTROD, of the beneficial kind, beftow, according to the value they bear in CHAP. VII. that capacity, upon the circumftances to which they owe their birth, the appellation of exculpative $\dagger$ or extenuative circumftances $t:$ if of the mifchievous kind, they beftow on them the appellation of aggravative circumftances $\|$. Of all thefe different fets of circumftances, the criminative are connected with the confequences of the original offence, in the way of production; with the act, and with one another, in the way of conjunct influence: the confequences of the original offence, with them, and with the act refpectively, in the way of derivation: the confequences of the modified offence, with the criminative, exculpative, and extenuative circumftances refpectively, in the way alfo of derivation: thefe different fets of circumftances, with the confequences of the modified act or offence, in the way of production: and with one another (in refpect of the confequences of the modified act or offence) in the way of conjunct influence. Laftly, whatever circumftances can be feen to be connected with the confequences of the offence, whether directly in the way of derivation, or obliquely in the way of collateral affinity (to wit, in virtue of its being connected, in the way of derivation, with fome of the circumftances with which they ftand connected in the fame manner) bear a material relation to the offence in the way of evidence, they may accordingly be ftiled evidentiary circumftances, and may become of ufe, by being held forth upon occafion as fo many proofs, indications, or evidences of its having been committed $\$$.

+ See B. I. tit. [Juftifications.] † See B. I. tit. [Extenuations.] \| See B. I. tit. [Aggravations.] \$See B. I. tit. [Acceffory Offences.] and B. II. tit. [Evidence.]

I It is evident that this analy fis is equally applicable to incidents of a purely phyfical nature, as to thofe in which moral agency is concerned. If therefore it be juft and ufeful here, it might be found not impolibble, perhaps, to find fome ufe for it in natural philofophy.

C H A P. 


\section{H A P. VIII.}

I.

Q much with regard to the two firft of the articles upon which the evil tendency of an action may depend: viz. the act itfelf, and the general affemblage of the circumftances with which it may have been accompanied. We come now to confider the ways in which the INTROD. CHAP. VIII. particular circumftance of intention may be concerned in it.

II.

Firft then, the intention or will may regard either of two objects: 'The intenti1. The act itfelf: or, 2. Its confequences. Of thefe objects, that which the intention regards may be ftiled intentional. If it regards the act, then the act may be faid to be intentional ${ }^{2}$ : if the confequences, fo alfo then may the confequences. If it regards both the act and confequences, the whole altion may be faid to be intentional. Whichever of thofe articles is not the object of the intention, may of courfe be faid to be unintentional.

III.

The act may very eafily be intentional without the confequences; and It may reoften is fo. Thus, you may intend to touch a man, without intending $\underset{\text { without any }}{\text { gard the act }}$ to hurt him: and yet, as the confequences turn out, you may chance to of the confehurt him.

on may regard, 1. The act: or,

2. The confe. quences.

a On this occafion the words voluntary and involuntary are commonly employed. Ambiguity of Thefe, however, I purpofely abftain from, on account of the extreme ambiguity of their the words vofignification. By a voluntary ad is meant fometimes, any act, in the performance of voluntary. which the will has had any concern at all; in this fenfe it is fynonymous to intentional: fometimes fuch alts only, in the production of which the will has been determined by motives not of a painful nature; in this fenfe it is fynonymous to unconftrained, or uncoerced: fometimes fuch acts only, in the production of which the will has been determined by motives, which, whether of the pleafurable or painful kind, occurred to a man himfelf, without being fuggefted by any body elfe; in this fenfe it is fynonymous to fpontaneous. The fenfe of the word involuntary does not correfpond compleatly to that of the word voluntary. Involuntary is ufed in oppofition to intentional; and to unconftrained : but not to fpontaneous. It might be of ufe to confine the fignification of the words voluntary and involuntary to one fingle and very narrow cafe, which will be mentioned in the next note. 
CHAP. VIII. The confequences of an act may alfo be intentional, without the act's

-or the con- being intentional throughout; that is, without its being intentional in
fequences fequences without regarding the act in all its ftages. every ftage of it: but this is not fo frequent a cafe as the former. You intend to hurt a man, fuppofe, by running againft him, and pufhing him down: and you run towards him accordingly: but a fecond man coming in on a fudden between you and the firft man, before you can ftop yourfelf, you run againt the fecond man, and by him puh down the firit.

$\mathrm{V}$.

-but not without regarding the firft fage.

But the confequences of an act cannot be intentional, without the act's being itfelf intentional in at Jeaft the firft ftage. If the act be not intentional in the firft ftage, it is no act of your's : there is accortingly no intention on your part to produce the confequences: that is to fay, the individual confequences. All there can have been on your part is a diftant intention to produce other confequences, of the fame nature, by fome act of your's, at a future time : or elfe, without any intention, a bare wifh to fee fuch event take place. The fecond man, fuppofe, runs of his own accord againft the firft, and pufhes him down. You had intentions of doing a thing of the fame nature: viz. To run againft him, and purh him down yourfelf; but you had done nothing in purfuance of thofe intentions: the individual confequences therefore of the act, which the fecond man performed in pufhing down the firft, cannot be faid to have been on your part intentional ${ }^{b}$.

VI. Secondly,

b To render the analyfis here given of the poffible ftates of the mind in point of intentionality abfolutely compleat, it mult be puthed to fuch a farther degree of minutenefs, as to rome eyes will be apt to appear trifling. On this account it feemed advifeable to difcard what follows, from the text to a place where any one who thinks proper may pals by it. An act of the body, when of the pofitive kind, is a motion : now in motion there are always three articles to be confidered: 1 . The quantity of matter that moves: 2. The direction in which it moves: and, 3. The velocity with which it moves. Correfpondent to thefe three articles, are fo many modes of intentionality, with regard to an act, confidered as being only in its firft ftage. To be compleatly unintentional, it muft be unintentional with refpect to every one of thefe three particu- 
VI.

INTROD.

Secondly. A confequence, when it is intentional, may either be direcily fo, or only obliquely. It may be faid to be directly or lineally intentional, when the profpect of producing it conftituted one of the links in the chain of caufes by which the perfon was determined to do the act. It may be faid to be obliquely or collaterally intentional, when, although the confequence was in contemplation, and appeared likely to enfue in cafe of the act's being performed, yet the profpect of producing fuch confequence did not conftitute a link in the aforefaid chain.

VII.

Thirdly. An incident, which is directly intentional, may either be ultimately fo, or only mediately. It may be faid to be ultimately intentional, when it ftands laft of all exterior events in the aforefaid chain of moWhen directly, ultimately fo, or tives; infomuch that the profpect of the production of fuch incident, could there be a certainty of its taking place, would be fufficient to determine the will, without the profpect of its producing any other. It may be faid to be mediately intentional, and no more, when there is fome other incident, the profpect of producing which forms a fub-

lars. This is the cafe with thofe afts which alone are properly termed involuntary : acts, in the performance of which the will has no fort of thare: fuch as the contrac. tion of the heart and arteries.

Upon this principle, acts that are unintentional in their firft ftage, may be diftinguimed into fuch as are compleatly unintentional, and fuch as are incompleatly unintentional : and thefe again may be unintentional, either in point of quantity of matter alone, in point of direction alone, in point of velocity alone, or in any two of thefe points together.

The example given further on may eafily be extended to this part of the analyfis, by any one who thinks it worth the while.

There feem to be occafions in which even thefe difquifitions, minute as they may appear, may not be without their uie in pranics. In the cafe of homicide, for example, and other corporal injuries, all the diltinctions here fpecified may occur, and in the courfe of trial may, for fome purpofe or other, require to be brought to mind, and made the fubject of difcourfe. What may contribute to render the mention of them pardonable, is the ufe that might poffibly be made of them in natural philofophy. In the hands of an expert metaphyfician, thefe, together with the foregoing chapter on human actions, and the fection on facts in general, in title Evidence of the Book of Procedure, might, perhaps, be made to contribute fomething towards an exhauftive analyfis of the poffible varieties of mechanical inventions.

Vol. I. 
INTROD. fequent link in the fame chain: infomuch that the profpect of producCнар. VIII. ing the former would not have operated as a motive, but for the tendency which it feemed to have towards the production of the latter.

VIII.

When directly intentional, it may be exclufively fo, or inexclu. fively.

When inexclufively, it may be conjunctively, disjunctively, or indifcriminately fo.

When difjunctively, it may be with or without preference.

Difference between an incident's being undisjundively inrentional, when the election is in
favour of the oiher.
Fourthly. When an incident is directly intentional, it may either be exclufively fo, or inexclufively. It may be faid to be exclufively intentional, when no other but that very individual incident would have anfwered the purpofe, infomuch that no other incident had any fhare in determining the will to the act in queftion. Ft may be faid to have been inexclufively * intentional, when there was fome other incident, the profpect of which was acting upon the will at the fame time.

IX.

Fifthly. When an incident is inexclufively intentional, it may be either conjunctively fo, difjunctively, or indifcriminately. It may be faid to be conjunctively intentional with regard to fuch other incident, when the intention is to produce both : disjunctively, when the intention is to produce either the one or the other indifferently, but not both: indifcriminately, when the intention is indifferently to produce either the one or the other, or both, as it may happen.

$\mathrm{X}$.

Sixthly. When two incidents are disjunctively intentional, they may be fo with or without preference. They may be faid to be fo with preference, when the intention is, that one of them in particular thould happen rather than the other: without preference, when the intention is equally fulfilled, whichever of them happens ${ }^{c}$.

\footnotetext{
- or concurrently.
}

c There is a difference between the cafe where an incident is altogether unintentional, and that in which, it being disjunetively intentional with reference to another, the preference is in favour of that other. In the fint cafe, it is not the intention of the party that the incident in quettion fhould happen at all : in the latter cafe, the intention is rather that the other flould happen: but if that cannot be, then that this in queltion fhould happen rather than that neither fhould, and that borh, at any rate, thould not happen.

All thefe are diftinctions to be attended to in the ufe of the particle or: a particle of very ambiguous import, and of great : importance in legillation. See Append. tit. [Compofition.]

XI. One 
$\mathrm{XI}$.

One example will make all this clear. William II. king of England, being out a ftag-hunting, received from Sir Walter Tyrrel a wound, Example. of which he died *. Let us take this cafe, and diverfify it with a variety of fuppofitions, correfpondent to the diftinctions juft laid down.

I, Firt then, Tyrrel did not fo much as entertain a thought of the king's death; or, if he did, looked upon it as an event of which there was no danger. In either of thefe cafes the incident of his killing the king was altogether unintentional.

2. He faw a ftag running that way, and he faw the king riding that way at the fame time : what he aimed at was to kill the ftag: he did not wifh to kill the king: at the fame time he faw, that if he fhot, it was as likely he hould kill the king as the ftag: yet for all that he thot, and killed the king accordingly. In this cafe the incident of his killing the king was intentional, but obliquely fo.

3. He killed the king on account of the hatred he bore him, and for no other reafon than the pleafure of deftroying him. In this cafe the incident of the king's death was not only directly but ultimately intentional.

4. He killed the king, intending fully fo to do; not for any hatred he bore him, but for the fake of plundering him when dead. In this cafe the incident of the king's death was directly intentional, but not ultimately: it was mediately intentional.

5. He intended neither more nor lefs than to kill the king. He had no other aim nor wifh. In this cafe it was exclufively as well as directly intentional: exclufively, to wit, with regard to every other material incident.

6. Sir Walter thot the king in the right leg, as he was plucking a thorn out of it with his left hand. His intention was, by thooting the arrow into his leg through his hand, to cripple him in both thofe limbs at the fame time. In this cafe the incident of the king's being thot in the leg was intentional : and that conjunctively with another which did not happen; viz. his being fhot in the hand.

\section{* Hume's hift.}


INTROD. 7. The intention of Tyrrel was to thoot the king either in the hand Crap. VIII. or in the leg, but not in both; and rather in the hand than in the leg. In this cafe the intention of hooting in the leg was disjunctively concurrent, with regard to the other incident, and that with preference.

8. His intention was to thoot the king either in the leg or the hand, whichever might happen; but not in both. In this cafe the intention was inexclufive, but disjunctively fo: yet that, however, without preference.

9. His intention was to thoot the king either in the leg or the hand, or in both, as it might happer. In this cafe the intention was indifcriminately concurrent, with refpect to the two incidents.

XII.

Intentionali- It is to be obferved, that an act may $\mathrm{Be}$ unintentional in any ftage ty of the act
with refpect with refpect fages, how far material.

hand, it may be intentional in any ftage or ftages of it, and yet unintentional in the fucceeding*. But whether it be intentional or no in any preceding ftage, is immaterial, with refpect to the confequences, fo it be unintentional in the laft. The only point, with refpect to which it is material, is the proof. The more ftages the act is unintentional in, the more apparent it will commonly be, that it was unintentional with refpect to the laft. If a man, intending to ftrike you on the cheek, ftrikes you in the eye, and puts it out, it will probably be difficult for him to prove that it was not his intention to ftrike you in the eye. It will probably be eafier, if his intention was really not to ftrike you, or even not to ftrike at all:

XIIT.

Goodnefs and badnefs of intention difmiffed.

It is frequent to hear men fpeak of a good intention, of a bad intention; of the goodnefs and badnefs of a man's intention: a circumftance on which great ftrefs is generally laid. It is indeed of no fmall importance, when properly underftood : but the import of it is to the laft degree ambiguous and obfcure. Strictly fpeaking, nothing can be faid to be good or bad, but either in itfelf; which is the cafe only with

- See ch. vii. [Actions] par. 14. 
pain or pleafure : or on account of its effects; which is the cafe only with things that are the caufes or preventives of pain and pleafure. But in a figurative and lefs proper way of fpeech, a thing may alfo be ftiled good or bad, in confideration of its caufe. Now the effects of an intention to do fuch or fuch an act, are the fame objects which we have been fpeaking of under the appellation of its confequences: and the caufes of intention are called motives. A man's intention then on any occafion may be ftiled good or bad, with reference either to the confequences of the act, or with reference to his motives. If it be deemed good or bad in any fenfe, it muft be either becaufe it is deemed to be productive of good or of bad confequences, or becaufe it is deemed to originate from a good or from a bad motive. But the goodnefs or badnefs of the confequences depend upon the circumftances. Now the circumftances are no objects of the intention. A man intends the act: and by his intention produces the act: but as to the circumftances, he does not intend them: he does not, inafmuch as they are circumftances of it, produce them. If by accident there be a few which he has been inftrumental in producing, it has been by former intentions, directed to former acts, productive of thofe circumftances as the confequences: at the time in queftion he takes them as he finds then. Acts, with their confequences, are objects of the will as well as of the underftanding: circumftances, as fuch, are objects of the underftanding only. All he can da with thefe, as fuch, is to know or not to know them: in other words, to be confcious of them, or not confcious. To the title of Confcioufnefs belongs what is to be faid of the goodnefs or badnefs of a man's intention, as refulting from the confequences of the act: and to the head of Motives, what is to be faid of his intention, as refulting from the motive. 
I.

INTROD. QO far with regard to the ways in which the will or intention may CHAP. IX. $S$ be concerned in the production of any incident: we come now to Connection confider the part which the underftanding or perceptive faculty may of this chapter with the
foregoing. have born, with relation to fuch incident.

Acts advifed and unadvifed: confciouneis, what.

II.

A certain act has been done, and that intentionally: that act was attended with certain circumftances: upon thefe circumftances depended certain of its confequences; and amongt the reft, all thofe which were of a nature purely phyfical. Now then, take any one of thefe circumftances, it is plain, that a man, at the time of doing the act from whence fuch confequences enfued, may have been either confcious, with refpect to this circumftance, or unconfcious. In other words, he may either have been aware of the circumftance, or not aware: it may either have been prefent to his mind, or not prefent. In the firft cafe, the act may be faid to have been an advifed act, with refpect to that circumftance: in the other cafe, an unadvifed one.

III.

Unadvifednefs may regard either exiftence, or materiality.

The circumftance may have been prefent, pat, or future.

Anunadrifed act may be heedlefs, or not heedlefs.

There are two points, with regard to which an act may have been advifed or unadvifed: I. The exiffence of the circumftance itfelf. 2. The materiality of it*
IV.

It is manifeft, that with reference to the time of the act, fuch circumftance may have been either prefent, paft, or future.

\section{$\mathrm{V}$.}

An act which is unadvifed, is either beedless, or not heedlefs. It is termed heedlefs, when the cafe is thought to be fuch, that a perfon of ordinary prudence $t$, if prompted by an ordinary thare of benevolence,
* See ch. vii. [Actions.] par. 3. $\quad$ + See ch. vi. [Senfibility.] par. iz.

would 
would have been likely to have beftowed fuch and fo much attention and reflection upon the material circumftances, as would have, effectually INTROD. difpofed him to prevent the mifohievous incident from taking place: not heedlefs, when the cafe is not thought to be fuch as above mentioned*.

VI.

Again. Whether a man did or did not fuppofe the exiftence or ma- A mif-adteriality of a given circumftance, it may be that he did fuppofe the what.-a exiftence and materiality of fome circumftance, which either did not mif-ruppofalexift, or which, though exifting, was not material. In fuch cafe the act may be faid to be mif-advifed, with refpect to fuch imagined circumftance : and it may be faid, that there has been an erroneous fuppofition, or a mif-suppofal in the cafe.

VII.

Now a circumftance, the exiftence of which is thus erroneouny furp- The fuppofed pofed, may be material either, I. In the way of prevention: or ${ }_{x} 2$. In circumftance that of compenfation. It may be faid to be material in the way of been material prevention, when its effect or tendency, had it exifted, would have in the way either of prebeen to prevent the obnoxious confequences : in the way of compenfa- vention or tion, when that effect or tendency would have been to produce other fation. confequences, the beneficialnefs of which would have out-weighed the mifchievoufnefs of the others.

VIII.

It is manifeft that, with reference to the time of the act, fuch ima- It may have ginary circumftance may in either cafe have been fuppofed either to be present, paft, or future.

\section{IX.}

been fuppofed prefent, paft, or future.

To return to the example exhibited in the preceding chapter.

10. Tyrrel intended to fhoor in the direction in which he fhot; but Example. continued he did not know that the king was riding fo near that way. In this from the latt cafe the act he performed in thooting, the act of hooting, was unadvifec, with refpect to the exiftence of the circumftance of the king's being fo near riding that way. 
INTROD. Ir. He knew that the king was riding that way: but at the diftance

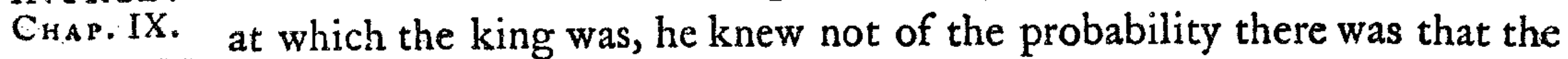
arrow would reach him. In this cafe the act was unadvifed, with refpect to the materiality of the circumftance.

12. Somebody had dipped the arrow in poifon, without Tyrrel's knowing of it. In this cafe the act was unadvifed, with refpect to the exiftence of a paft circumftance.

13. At the very inftant that Tyrrel drew the bow, the king, being fcreened from his view by the foliage of fome buthes, was riding furioufly, in fuch manner as to meet the arrow in a direct line? which circumftance was alfo more than Tyrrel knew of. In this cafe the act was unadvifed, with refpect to the exiftence of a prefent circumftance.

14. The king being at a diftance from court, could get nobody to drefs his wound till the next day; of which circumftance Tyrrel was not aware. In this care the act was unadvifed, with refpect to what was then a future circumftance.

I 5. Tyrrel knew of the king's being riding that way, of his being fo near, and fo forth; but being deceived by the foliage of the buthes, he thought he faw a bank between the fpot from which he hot, and that to which the king was riding. In this cafe the act was mif-advifed, proceeding on the mif-suppofal of a preventive circumftance.

16. Tyrrel knew that every thing was as above, nor was he deceived by the fuppofition of any preventive circumftance. But he believed the king to be an ufurper: and fuppofed he was coming up to attack a perfon whom Tyrrel believed to be the rightful king, and who was riding by Tyrrel's fide. In this cale the act was alfo mif-advifed, but proceeded on the mif-fuppofal of a compenfative circumftance.

$\mathrm{X}$.

In what cafe confcioufners extends the intentionality from the act to the confequences.
Let us obferve the connection there is between intentionality and confcioufners. When the act itfelf is intentional, and with refpect to the exiftence of all the circumftances advifed, as alfo with refpect to the materiality of thofe circumftances, in relation to a given confequence, and there is no mif-fuppofal with regard to any preventive circumftance, 
circumftance, that confequence muft alfo be intentional : in other words; advifednefs, with refpect to the circumftances, if clear from the mirfuppofal of any preventive circumftance, extends the intentionality from Chap. IX. the act to the confequences. Thofe confequences may be either directly intentional, or only obliquely fo: but at any rate they cannot but be intentional.

\section{$\mathrm{XI}$.}

To go on with the example. If Tyrrel intended to fhoot in the direction in which the king was riding up, and knew that the king was cuming to meet the arrow, and knew the probability there was of his being thot in that fame part in which he was fhot, or in another as dangerous, and with that fame degree of force, and fo forth, and was not mined by the erroneous fuppofition of a circumftance by which the fhot would have been prevented from taking place, or any fuch other preventive circumftance, it is plain he could not but have intended the king's death. Perhaps he did not politively wirh it; but for all that, in a certain fenfe he intended it.

XII.

What heedleffnefs is in the cafe of an unadvifed aet, rafhnefs is in A mifadvifed the cafe of a mifadvifed one. A mifadvifed act then may be either act may be the rafh. be fuch, that a perfon of ordinary prudence, if prompted by an ordinary thare of benevolence, would have employed fuch and fo much attention and reflection to the imagined circumftance, as, by difcovering to him the non-exiftence, improbability, or immateriality of it, would have effectually difpofed him to prevent the mifchievous incident from taking place.

XIII.

In ordinary difcourfe, when a man does an at of which the confe- The intenquences prove mifchievous, it is a common thing to fpeak of him as having acted with a good intention or with a bad intention, of his intention's being a good one or a bad one. The epithets good and bad are all this while applied, we fee, to the intention: but the applica-

are all this while applied, we fee, to the intention: but the applica- as well as the
tion of them is moft commonly governed by a fuppofition formed with fequences.
Vor. I.
$\mathrm{N}$ 
INTROD, regard to the nature of the motive. The act, though eventually it Chap. IX. prove mifchievous, is faid to be done with a good intention, when it is fuppofed to iffue from a motive which is looked upon as a good motive: with a bad intention, when it is fuppofed to be the refult of a motive which is looked upon as a bad motive. But the nature of the confequences intended, and the nature of the motive which gave birth to the intention, are objects which, though intimately connected, are perfectly diftinguifhable. The intention might therefore with perfect propriety be ftiled a good one, whatever were the motive. It might be ftiled a good one, when not only the confequences of the act prove mifchievous, but the motive which gave birth to it was what is called a bad one. To warrant the fpeaking of the intention as being a good one, it is fufficient if the confequences of the act, had they proved what to the agent they feemed likely to be, would have been of a beneficial nature. And in the fame manner the intention may be bad, when not only the confequences of the act prove beneficial, but the motive which gave birth to it was a good one.

\section{XIV.}

It is tetter, Now, when a man has a mind to fpeak of your intention as being when the in- good or bad, with reference to the confequences, if he fpeaks of it at
tention is meant to be fpoken of as being good or bad, not to fay, the motive. all he muft ufe the word intention, for there is no other. But if a man means to fpeak of the motive from which your intention originated, as being a good or a bad one, he is certainly not obliged to ufe the word intention: it is at leaft as well to ufe the word motive. By the fuppofition he means the motive; and very likely he may not mean the intention. For what is true of the one is very often not true of the other. The motive may be good when the intention is bad: the intention may be good when the motive is bad: whether they are both good or both bad, or the one good and the other bad, makes, as we thall fee hereafter, a very effential difference with regard to the confequences*. It is therefore much better, when motive is meant, never to fay intention.

- See ch. xii. [Confequences.] 


\section{Of [CONSCIOUSNESS.]}

XV.

INTROD.

An example will make this clear. Out of malice a man profecutes you for a crime of which he believes you to be guilty, but of which in fact you are not guilty. Here the confequences of his conduct are mifchievous : for they are mifchievous to you at any rate, in virtue of the thame and anxiety which you are made to fuffer while the profecution is depending: to which is to be added, in cafe of your being convicted, the evil of the punifhment. To you therefore they are mifchievous; nor is there any one to whom they are beneficial. The man's motive was alfo what is called a bad one: for malice will be allowed by every body to be a bad motive. However, the confequences of his conduct, had they proved fuch as he believed them likely "to be, would have been good: for in them would have been included the puninment of a criminal, which is a benefit to all who are expofed to fuffer by a crime of the like nature. The intention therefore, in this cafe, though not in a common way of fpeaking the motive, might be ftiled a good one. But of motives more particularly in the next chapter.

XVI.

In the fame fenfe, the intention, whether it be pofitively good or no, fo long as it is not bad, may be termed innocent. Accordingly, let the confequences have proved mifchievous, and let the motive have been what it will, the intention may be termed innocent in either of two cafes: $r$. In the cafe of un-advifednefs with refpect to any of the circumftances on which the mifchievoufnefs of the confequences depended: 2. In the cafe of mif-advifednefs with refpect to any circumftance, which, had it been what it appeared to be, would have ferved either to prevent or to outweigh the mifchief.

\section{XVII.}

A few words for the purpore of applying what has been faid to the Roman law. Unintentionality, and innocence of intention, feem both to be included in the cafe of infortunium, where there is neither dolus nor culpa. Un-advifednefs coupled with heedleffnefs, and mif-advifednefs coupled with rafhnefs, correfpond to the culpa fine dolo. Direet intentionality correfponds to dolus. Oblique intentionality feems hardly

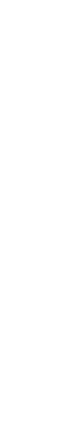

Intentionality and confcioufnefs how fpoken of in the Roman law. 
INTROD. to have been diftinguifhed from direct; were it to occur, it would proChap. iX. bably be deemed alfo to correfpond to dolus. The divifion into culpa, lata, levis, and levifima, is fuch as nothing certain can correfpond to. What is it that it expreffes? A diftinction, not in the cafe itfelf, but only in the fentiments which any perfon (a judge, for inftance) may find himfelf difpofed to entertain with relation to it: fuppofing it already diftinguined into three fubordinate cafes by other means.

The word dolus feems ill enough contrived: the word culpa as indifferently. Dolus, upon any other occafion, would be underftood to imply deceit, concealment, ${ }^{*}$ clandeftinity ${ }^{\text {* }}$ : but here it is extended to open force. Culpa, upon any other occafion, would be underftood ta extend to blame of every kind. It would therefore include dolus ${ }^{\circ}$.

$$
\text { XVIII. }
$$

Ufe of this and the preceding chapter.
The above-mentioned definitions and diftinctions are far from being mere matters of fpeculation. They are capable of the moft extenfive

- See B. I. tit. [Theft] uerbo [amenable. I

a Dolus, an virtus quis in holte requirit? Vargri.

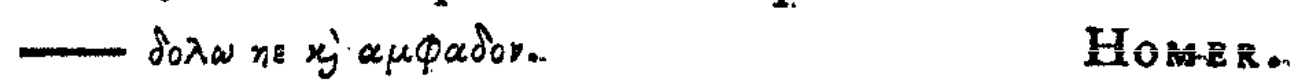

- I pretend not here to give any determinate explanation of a fet of words, of which the great misfortune is, that the import of them is confufed and indeterminate. $F$ fpeak only by approximation. To attempt to determine the precife import that has been given them by a hundredth part of the authors that have ufed them, would be an endlefs tafk. Would any one talk intelligibly on this fubject in Latin? let him throw out dolus altogether: let him keep culpa, for the purpofe of expreffing not the cafe itfelf, but the fentiment that is entertained concerning a cafe defcribed by other means. For intentionality, let him coin a word boldly, and fay intentionalitas: for unintentionality, non-intentionalitas. For unadvifednefs, he has already the word infitia; tho' the words imprudentia, inobfervantia, were it not for the other fenfes they are ufed in,. would do better : for unadvifednefs coupled with heedleffnefs, let him fay infcitia culpabilis: for unadvifednefs without heedleffnefs, infcitia iñculpabizizis: for mif-advifednefs coupled with rafhnefs, error culpabilis, errar temerarius, or error cum temeritate : for mif-advifednefs without rafhnefs, error inculpabilis, error non temerarius, or error fine temerifate.

It is not unfrequent likewife to meet with the phrafe, malo animo: a phrafe ftill more indeterminate, if poffible, than any of the former. It feems to have reference eithar to intentionality, or to confcioufnefs, or to the motive, or to the difpofition, or to any two or more of thefe taken together; nobody can tell which : thefe being objects which feem to have never hitherto been properly diftinguilhed and defined.

and 


\section{of [ CON S C I O US NES S.]}

and conftant application, as well to moral difcourfe as to leginative practice. Upon the degree and bias of a man's intention, upon the abfence or prefence of confcioufnefs or mif-fuppofal, depend a great part of the good and bad, more efpecially of the bad confequences of an act; and on this, as well as other grounds, a great part of the demand for punifhment*. The prefence of intention with regard to fuch or fuch a confequence, and of confcioufnefs with regard to fuch or fuch a circumftance, of the act, will form fo many criminative circumftances $\dagger$, or effential ingredients in the compofition of this or that offence: applied to other circumftances, confcioufnefs will form a ginund of aggravation, annexable to the like offence $\$$. In almoft all caires, the abfence of intention with regard to certain confequences, and the abfence of confcioufnefs, or the prefence of mif-fuppofal, with regard to certain circumftances, will conftitute fo many grounds of extenuation $\|$.

- See ch. xiii. [Cares unmeet.] t Se B. I. tit. [Aggravations.]
† See B. I. tit. [Circumftances influencing.] II See B. I. tit. [Extenuations.] 


\section{C $\mathrm{H}$ A P. X.}

$\$$ I. Different jenfes of the word motive.

\section{I.}

INTROD. $T \mathrm{~T}$ is an acknowledged truth, that every kind of act whatever, and CHAP.X. 1 confequently every kind of offence, is apt to affume a different Motives, why character, and be attended with different effects, according to the nature of the motive which gives birth to it. This makes it requifite to take a view of the feveral motives by which human conduct is liable to be influenced.

II.

Purely fpeculative motives have nothing to do here.

By a motive, in the moft extenfive fenfe in which the word is ever ufed with reference to a thinking being, is meant any thing that can contribute to give birth to, or even to prevent, any kind of action. Now the action of a thinking being is the act either of the body, or only of the mind: and an act of the mind is an act either of the intellectual faculty, or of the will. Acts of the intellectual faculty will fometimes reft in the underftanding merely, without exerting any influence in the production of any acts of the will. Motives, which are not of a nature to influence any other acts than thofe, may be ftiled purely speculative motives, or motives refting in speculation. But as to thefe acts, neither do they exercife any influence over external acts, or over their confequences, nor confequently over any pain or any pleafure that may be in the number of fuch confequences. Now it is only on account of their tendency to produce either pain or pleafure, that any acts can be material. With asts, therefore, that reft purely in the underftanding, we have not here any concern: nor therefore with any object, if any fuch there be, which, in the character of a motive, can have no influence on any other acts than thofe.

III.

Motives to The motives with which alone we have any concern, are fuch as are the will. of a nature to act upon the will. By a motive then, in this fenfe of 


\section{of $\left[\begin{array}{lllllll}M & O & T & I & V & E & S .\end{array}\right.$}

the word, is to be underftood any thing whatfoever, which, by in- INTROD. fluencing the will of a fenfitive being, is fuppofed to ferve as a means of determining him to act, or voluntarily to forbear ${ }^{2}$ to act, upon any occafion. Motives of this fort, in contradiftinction to the former, may be ftiled praftical motives, or motives applying to practice.

IV.

Owing to the poverty and unfettled ftate of language, the word motive is employed indifcriminately to denote two kinds of objects, which, for the better underftanding of the fubject, it is neceffary thould Figurative and unfigurative fenfes of be diftinguifhed. On fome occafions it is employed to denote any of thore really exifting incidents from whence the act in queftion is fuppofed to take its rife. The fenfe it bears on thefe occafions may be ftiled its literal or unfigurative fenfe. On other occafions it is employed to denote a certain fictitious entity, a paffion, an affection of the mind, an ideal being which upon the happening of any fuch incident is confidered as operating upon the mind, and prompting it to take that courfe, towards which it is impelled by the influence of fuch incident. Motives of this clafs are Avarice, Indolence, Benevolence, and fo forth; as we thall fee more particularly farther on. This latter may be ftiled the figurative fenfe of the term motive.

$\mathrm{V}$.

As to the real incidents to which the name of motive is alfo given, Motives in. thefe too are of two very different kinds. They may be either, I. The terior and internal perception of any individual lot of pleafure or pain, the expectation of which is looked upon as calculated to determine you to act in fuch or fuch a manner; as the pleafure of acquiring fuch a fum

2 When the effect or tendency of a motive is to determine a man to forbear to act, it may feem improper to make ufe of the term motive: fince motive, properly fpeaking, means that which difpofes an object to move. We muft however ufe that improper term, or a term which, though proper enough, is fcarce in ufe, the word determinative. By way of juftification, or at leaft apology, for the popular ufage in this behalf, it may be obferved, that even forbearance to act, or the negation of motion (that is, of bodily motion) fuppofes an adt done, when fuch forbearance is voluntary. It fuppofes, to wit, an act of the will, which is as much a pofitive act, as much a motion, as any other act of the thinking fubftance. 
INTROD. of money, the pain of exerting yourfelf on fuch an occafion, and fo Chap.X. forth: Or 2. Any external event, the happening whereof is regarded as having a tendency to bring about the perception of fuch pleafure or fuch pain : for inftance, the coming up of a lottery ticket, by which the poffeffion of the money devolves to you; or the breaking out of a fire in the houfe you are in, which makes it neceffary for you to quit it. The former kind of motives may be termed interior, or internal : the latter exterior, or external.

VI.

Motive in Two other fenfes of the term motive need alfo to be diftinguißhed. propsect-inefe. Motive refers neceffarily to action. It is a pleafure, pain, or other event, that prompts to action. Motive then, in one fenfe of the word, muft be previous to fuch event. But, for a man to be governed by any motive, he muft in every cafe look beyond that event which is called his action; he muft look to the confequences of it: and it is only in this way that the idea of pleafure, of pain, or of any other event, can give birth to it. He muft look, therefore, in every cale, to fome event pofterior to the act in contemplation : an event which as yet exifts not, but ftands only in profpect. Now, as it is in all cafes difficult, and in moft cafes unneceffary, to diftinguifh between objects fo intimately connected, as the pofterior poffible object which is thus looked forward to, and the prefent exifting object or event which takes place upon a man's looking forward to the other, they are both of them fpoken of under the fame appellation, motive. To diftinguifh them, the one firft-mentioned may be termed a motive in profpect, the other a motive in effe: and under each of thefe denominations will come as well exterior as internal motives. A fire breaks out in your neighbour's houfe: you are under apprehenfion of its extending to your own: you are apprehenfive, that if you ftay in it, you will be burnt: you accordingly run out of it. This then is the act: the others are all motives to it. The event of the fire's breaking out in your neighbour's houfe is an external motive, and that in effe: the idea or belief of the probability of the fire's extending to your own houfe, that of your being burnt if you continue, and the pain you feel at the thought of fuch a cataftrophe, are all fo 


\section{of $\left[\begin{array}{lllllll}M & O & T & I & V & E & S .\end{array}\right]$}

Xcvii

many internal events, but ftill in effe: the event of the fire's actually extending to your own houfe, and that of your being actually burnt by it, external motives in profpect : the pain you would feel at feeing your houfe a burning, and the pain you would feel while you yourfelf were burning, internal motives in profpect: which events, according as the matter turns out, may come to be in effe: but then of courfe they will ceafe to act as motives.

\section{VII.}

Of all thefe motives, that which ftands neareft to the act, to the production of which they all contribute, is that internal motive in effe which confifts in the expectation of the internal motive in profpect: the pain or uneafinefs you feel at the thoughts of being burnt ${ }^{b}$. All other motives are more or lefs remote: the motives in profpect, in proportion as the period at which they are expected to happen is more diftant from the period at which the act takes place, and confequently later in point of time: the motives in effe, in proportion as they alfo are more diftant from that period, and confequently earlier in point of time ${ }^{c}$.

\section{VIII.}

It has already been obferved, that with motives of which the influence terminates altogether in the underftanding, we have nothing here to do. If then, among objects that are fpoken of as motives with reference to the underftanding, there be any which concern us here, it

Motives im. mediate and remote.

b Whether it be the expectation of being burnt, or the pain that accompanies that expectation, that is the immediate internal motive fpoken of, may be difficult to determine. It may even be queftioned, perhaps, whether they are diftinct entities. Both queftions, however, feem to be mere queftions of words, and the folution of them altogether immaterial. Even the other kinds of motives, though for fome purpofes they demand a feparate confideration, are, however, fo intimately allied, that it will often be fcarce practicable, and not always material, to avoid confounding them, as they have always hitherto been confounded.

c Under the term efe muft be included as well paft exiftence, with reference to a given period, as prefent. They are equally real, in comparifon of what is as yet but future. Language is materially deficient, in not enabling us to diftinguifh with precifion between exiftence as oppofed to unreality, and prefent exiftence as oppofed to paft. The word exiftence in Englifh, and efe adopted by lawyers from the Latin, have the inconvenience of appearing to confine the exiftence in quettion to fome fingle period confidered as being prefent.

VOL. I.

Miotives to the under. ftanding how they may in. fluence the will. 
INTROD. is only in as far as fuch objects may, through the medium of the unCHAP. X. derftanding, exercife an influence over the will. It is in this way, and in this way only, that any objects; in virtue of any tendency they may have to influence the fentiment of belief, may in a practical fenfe act in the character of motives. Any objects, by tending to induce a belief concerning the exiftence, actual or probable, of a practical motive; that is, concerning the probability of a motive in profpect, or the exiftence of a. motive in effe; may exercife an influence on the will, and rank with thofe other motives that have been placed under the name of practical. The pointing out of motives fuch as thefe, is what we frequently mean, when we talk of giving reafons. Your neighbour's houfe is on fire, as: before. I obferve to you, that at the lower part of your neighbour's houfe is fome wood-work, which joins on to your's; that the fames have. caught this wood-work, and fo forth; which I do, in order to difpofe. you to believe as I believe, that if you ftay in your houfe much longer you will be burnt. In doing thus then I fuggeft motives. to your underftanding; which motives, by the tendency they have to give birth. to or ftrengthen a pain, which operates upon you in the character of an internal motive in $e \int f e$, join their force to that of the reft, and act as. motives upon the will.

\section{\$2. No motives either conftantly good or conftantly bad.}

IX.

Nothing can act of itfelf as a motive, but the idea of pleafure or pain.

No fort of motive is in itfelf a bad one.
In all this chain of motives, the principal or original link feems to be the laft internal motive in profpect: it is to this that all the other motives in profpect owe their materiality : and the immediately acting. motive its exiftence. This motive in profpect, we fee, is always fome pleafure, or fome pain: fome pleafure, which the act in queftion is expected: to be a means of continuing or producing : fome pain, which it is expected to be a means of difcontinuing or preventing. A motive is fubftantially nothing more than pleafure or pain, opcrating in a certain manner.

\section{$\mathrm{X}$.}

Now pleafure is in itfelf a good: nay, even fetting afide immunity from pain, the only good: pain is in itfelf an evil; and indeed, without exception, the only evil: or elfe the words good and evil have no meaning. 


\section{of $\left[\begin{array}{lllllll}M & \mathrm{O} & \mathrm{T} & \mathrm{I} & \mathrm{V} & \mathrm{E} & \mathrm{S} .\end{array}\right]$}

xcix

meaning. And this is alike true of every fort of pain, and of every fort of pleafure. It follows, therefore, immediately and inconteftibly, that there is no fuch thing as any fort of motive that is in itfelf a bad oned.

XI.

It is common, however, to fpeak of actions as proceeding from gapd or from bad motives: in which cafe the motives meant are fuch as are internal. The expreffion is far from being an accurate one: and as it is apt to occur in the confideration of almoft every kind of offence, it will be requifite to fettle the precife meaning of it, and obferve how far it quadrates with the truth of things.

XII.

With refpect to goodnefs and badnefs, as it is with every thing elfe that is not itfelf either pain or pleafure, fo is it with motives. If they are good or bad, it is only on account of their effects : good, on account of their tendency to produce pleafure, or aiert pain: bad, on account of their tendency to produce pain, or avert pleafure. Now the cafe is, that from one and the fame motive, and from every kind of motive, may proceed actions that are good, others that are bad, and others that are indifferent. This we fhall proceed to thew with refpeet to all the different kinds. of motives, as determined by the various kinds of pleafures and pains.

XIII.

Such an analyfis, ufeful as it is, will be found to be a matter of Difficulties no fmall difficulty; owing in great meafure to a certain perverfity of ftructure which prevails more or lefs throughout all languages. - To fpeak of motives, as of any thing elfe, one muft call them by their names. But the misfortune is, that it is rare to meet with a motive of which the name expreffes that and nothing more. Commonly, along with the very name of the motive, is tacitly involved a propofi-

d Let a man's motive be ill-will; call it even malice, envy, cruelty : it is till a kind of pleafure that is his motive : the pleafure he takes at the thoughts of the pain which he fees, or expects to fee, his adverfary undergo. Now even this wretched pleafure, taken by itfelf, is good : it may be faint; it may be fhort: it muft at any rate be impure : yet while it lafts, and before any bad confequences arrive, it is as good as any other that is not more intenfe. See ch. iv. [Value.] which Atand in the way of an analyfis of

Any fort of motive may give birth to act. this fort. 
INTROD: tion, imputing to it a certain quality; a quality which, in many cafes, Cнав.X. will appear to include that very goodnefs or badnefs, concerning which we are here enquiring whether, properly fpeaking, it be or be not imputable to motives. To ufe the common phrafe, in moft cafes, the name of the motive is a word which is employed either only in a good fenfe, or elfe only in a bad fenfe. Now, when a word is fpoken of as being ufed in a good fenfe, all that is neceffarily meant is this: that in conjunction with the idea of the object it is put to fignify, it conveys an idea of approbation: that is, of a pleafure or fatisfaction, entertained. by the perfon who employs the term, at the thoughts of fuch object. In like manner, when a word is fpoken of as being ufed in a bad fenfe, all that is neceffarily meant is this: that, in conjunction with the idea. of the object it is put to frgnify, it conveys an idea of difapprobation: that is, of a difpleafure entertained by the perfon who employs the term, at the thoughts of fuch object. Now, the circumftance on which fuch approbation is grounded will, as naturally as any other, be the opinion of the goodne/s of the object in queftion, as above explained: fuch, at leaft, it muft be, upon the principle of utility. So, on the other hand, the circumftance on which any fuch difapprobation is grounded, will, as naturally as any other, be the opinion of the badness of the object : fuch, at leaft, it muft be, in as far as the principle of utility is taken for the ftandard.

Now there are certain matives. which, unlefs in a few particular cafes, have fearcely any other name to be expreffed by but fuch a word as is ufed only in a good fenfe. This is the cafe, for example, with. the motives of piety and honour. The confequence of this is, that if, in fpeaking of fuch a motive, a man fhould have occafion to apply the epithet bad to any actions which he mentions as apt to refult from it, he mutt appear to be guilty of a contradiction in terms. But the names of motives which have fcarcely any other name to be expreffed by, but fuch a word as is ufed only in a bad fenfe, are many more*. This is the cafe, for example, with the motives of luft and avarice. And accordingly, if in fpeaking of any fuch motive, a man hould have occafion to apply the epithets good or indifferent to any actions which he men-

- For the reafon, fee Chap. xi. [Difpofitions] par, xvii, note. 
tions as apt to refult from it, he muft here alfo appear to be guilty of INTROD. a fimilar contradiction e.

This perverfe affociation of ideas cannot, it is evident, but throw great difficulties in the way of the enquiry now before us. Confining himfelf to the language moft in ufe, a man can fcarce avoid running, in appearance, into perpetual contradictions. His propofitions will appear, on the one hand, repugnant to truth; and, on the other hand, adverfe to utility. As paradoxes, they will excite contempt: as mifchievous paradoxes, indignation. For the truths he labours to convey, however important, and however falutary, his reader is never the better: and he himfelf is much the worfe. To obviate this inconvenience compleatly, he has but this one unpleafant remedy; to lay afide the old phrafeology, and invent a new one. Happy the man whofe language is ductile enough to permit him this refource. To palliate the inconvenience, where that method of obviating it is impracticable, he has nothing left for it but to enter into a long difcuffion, to ftate the whole matter at large, to confefs, that for the fake of promoting the purpofes, he has violated the eftablifhed laws of language, and to throw himfelf upon the mercy of his readers $\mathrm{f}$.

- To this imperfection of language; and nothing more, are to be attributed, in great meafure, the violent clamours that have from time to time been raifed againft thofe ingenious moralifs, who, travelling out of the beaten track of fpeculation, have found more or lefs difficulty, in difentangling themfelves from the fhackles of ordinary language : fuch as Rochefoucault, Mandeville, and Helvetius. To the unfoundnefs of their opinions, and, with ftill greater injuftice, to the corruption of their hearts, was often imputed, what was moft commonly owing either to a want of fkill in matters of language on the part of the author, or a want of difcernment, poffibly now and then. in fome infances a want of probity, on the part of the commentator.

f Happily, language is not always fo intractable, but that by making ufe of two words inftead of one, a man may avoid the inconvenience of fabricating words that are abfolutely new. Thus, inftead of the word $\operatorname{lnf}$, by putting together two words, in common ufe, he may frame the neutral expreflion, venereal defire: inftead of the word avarice, by putting together two other words, alfo in common ufe, he may frame the neutral exprefion, pecuniary interef. This, accordingly, is the courfe which $I$ have taken. In thefe inftances, indeed, even the combination is not novel: the only no. 
INTROD.

Chap. X.

Phyfical defire corre-

fponding to pleafures of fenfe in general.

The motive correfponding to the pleafures of che palate.

\section{\$. Catalogue of motives corresponding to that of Pleafures and Pains.}

XIV.

From the pleafures of the fenfes, confidered in the grofs, refults the motive which in a neutral fenfe may be termed phyfical defire: in a bad fenfe, it is termed fenfuality. Name ufed in a good fenfe, it has none. Of this, nothing can be determined, till it be confidered feparately, with reference to the feveral fpecies of pleafures to which it correfponds.

$$
\mathrm{XV} \text {. }
$$

In particular, then, to the pleafures of the tafte or palate correfponds a motive, which in a neutral fenfe having received no name that can ferve to exprefs it in all cafes, can only be termed, by circumlocution, the love of the pleafures of the palate. In particular cafes it is ftiled hunger: in others, thirft 8 . The love of good cheer expreffes this motive, but feems to go beyond: intimating, that the pleafure is to be partaken of in company, and involving a kind of fympathy. In a bad fenfe, it is ftiled in fome cafes greedinefs, voracioufnefs, gluttony: in others, principally when applied to children, liquorifhnefs. It may in fome cafes alfo be reprefented by the word daintinefs. Name ufed in a good fenfe, it has none.

r. A boy, who does not want for victuals, fteals a cake out of a paftry-cook's hop, and eats it. In this cafe his motive will be univerfally deemed a bad one: and if it be alked what it is, it may be anfwered, perhaps, liquorifhnefs. 2. A boy buys a cake out of a paftry-cook's fhop,

velty there is confifts in the fteady adherence to the one neutral expreffion, rejecting altogether the terms, of which the import is infected by adventitious and unfuitable ideas.

In the catalogue of motives, correfponding to the feveral forts of pains and pleafures, I have inferted fuch as have occurred to me. I cannot pretend to warrant it compleat. To make fure of rendering it fo, the only way would be, to turn over the dictionary from beginning to end : an operation which, in a view to perfection, would be neceflary for more purpofes than this. See B. I. tit. [Defamation] and Append. tit. [Compofition.]

B Hunger and thirf, confidered in the light of motives, import not fo much the defire of a particular kind of pleafure, as the defire of removing a pofitive kind of pain. They do not extend to the defire of that kind of pleafure which depends on the choice of foods and liquors. 
and eats it. In this cafe his motive can fcarcely be looked upon as either good or bad, unlefs his mafter fhould be out of humour with him; and then, perhaps, he may call it liquorifhnefs, as before. In both cafes, however, his motive is the fame. It is neither more nor lefs than the motive correfponding to the pleafures of the palate ${ }^{\mathrm{b}}$.

XVI.

To the pleafures of the venereal fenfe correfponds the motive which, in a neutral fenfe, may be termed venereal defire. In a bad fenfe, it is fpoken of under the name of lafcivioufnefs, and a variety of other names of reprobation. Name ufed in a good fenfe, it has none!

INTROD. Cha.p. X.

I. A man ravihes a virgin. In this cafe the motive is, without foruple, termed by the name of luft, lafcivioufnefs, and fo forth; and is univerfally looked upon as a bad one. 2. The fame man, at another time, exercifes the rights of marriage with his wife. In this cafe the motive is accounted, perhaps, a good one, or at leaft indifferent : and here people would fcruple to call it by any of thofe names. In both cafes, however, the motive may be precifely the fame. In both cafes it may be neither more nor lefs than that of venereal defire.

\section{XVII.}

To the pleafures of curiofity correfponds the motive known by the fame name: and which may be otherwife called the love of novelty, or the love of experiment; and, on particular occafions, fport, and fometimes play.

1. A boy, in order to divert himfelf, reads an improving book: the

- It will not be worth while, in every cafe, to give an inftance in which the action may be indiferent: if good as well as bad actions may refult from the fame motive, it is eafy to conceive, that fo alfo may indifferent.

Love indeed includes fometimes this idea : but then it can never anfwer the purpofe of exhibiting it feparately: fince there are three motives, at ieal, that may all of them be included in it, befides this : the love of beauty correfponding to the pleafures of the eye, and the motives correfponding to thofe of amity and benevolence. We fpeak of the love of children, of the love of parents, and the love of God. Thefe pious ufes protect the appellation, and preferve it from the ignominy poured forth upon its profane aflociates. Even fenfual love would not anfwer the purpofe; fince that would include the love of beauty.

Venereal defire correfponding to the pleafures of the venereal fenfe.
Curiofity, \&c. correthe pleafures of curiofity.

motive 
INTROD. motive is accounted, perhaps, a good one: at any rate not a ball one Chap. $X$, 2. He fets his top a fpinning: the motive is deemed, at any rate, not a bad one. 3. He lets loofe a mad ox among a crowd: his motive is now, perhaps, termed an abominable one. Yet in all three cafes the motive may be the very fame: it may be neither more nor lefs than curiofity.

\section{XVIII.}

None to the other pleafures of fenfe.

As to the other pleafures of fenfe, they are of too little confequence to have given any feparate denominations to the correfponding motives.

XIX.

Pecuniary interett to the pleafures of wealth.

To the pleafures of wealth correfponds the fort of motive, which, in a neutral fenfe, may be termed pecuniary intereft. In a bad fenfe, it is termed, in fome cafes, avarice, covetoufnefs, rapacity, or lucre: in other cafes, niggardlinefs: in a good fenfe, but only in particular cafes, ceconomy and frugality; and in fome cafes the word induftry may be applied to it. In a fonfe nearly indifferent, but rather bad than otherwife, it is ftiled, though only in particular cafes, parfimony.

1. For money, you gratify a man's hatred, by putting his adverfary to death. 2. For money, you plow his field for him. In the firft cafe your motive is termed lucre, and is accounted corrupt and abominable: in the fecond, for want of a proper appellation, it is ftiled induftry; and is looked upon as innocent at leaft, if not meritorious. Yet the motive is in both cafes precifely the fame: it is neither more nor lefs than that of pecuniary intereft.

\section{XX.}

None to the pieafures of fkill.

The pleafures of fkill are neither diftinet enough, nor of confequence enough, to have given a name to the correfponding motive.

\section{XXI.}

To the plea- To the pleafures of amity correfponds a motive which, in a neutral ty, the defire fenfe, may be termed the defire of ingratiating one's felf. In a bad of ingratiat- fenfe, it is, in certain cafes, ftiled fervility: in a good fenfe, it has no ing one's felf. name that is peculiar to it. In the cafes in which it has been looked 
on with a favourable eye, it has feldom been diftinguifhed from the motive of fympathy or benevolence, with which, in fuch cafes, it is commonly affociated.

1. To acquire the affections of a woman before marriage, to preferve them afterwards, you do every thing, that is confiftent with other duties, to make her happy: in this cafe your motive is looked upon as laudable, though there is no name for it. 2. For the fame purpofe, you poifon a woman with whom the is at enmity: in this cafe your motive is looked upon as abominable, though ftill there is no name for it. 3. To acquire or preferve the favour of a man who is richer or more powerful than yourfelf, you make yourfelf fubfervient to his pleafures. Let them even be lawful pleafures, if people chufe to attribute your behaviour to this motive, you will not get them to find any other name for it than fervility. Yet in all three cafes the motive is the fame: it is neither more nor lefs than the defire of ingratiating yourfelf.

\section{XXII.}

To the pleafures of the moral fanction, or, as they may otherwife be called, the pleafures of a good name, correfponds a motive which, in a neutral fenfe, has fcarcely yet obtained any adequate appellative. It may be ftiled, the love of reputation. It is nearly related to the motive laft preceding: being neither more nor lefs than the defire of ingratiating one's felf with, or, as in this cafe we fhould rather fay, of recommending one's felf to, the world at large. In a good fenfe, it is termed honour, or the fenfe of honour: or rather, the word honour is introduced fomehow or other upon the occafion of its being brought to view : for in ftrictnefs the word honour is put rather to fignify that imaginary object, which a man is fpoken of as poffeffing upon the occafion of his obtaining a confpicuous fhare of the pleafures that are in queftion. In particular cafes, it is ftiled the love of glory. In a bad fenfe, it is ftiled, in fome cafes, falfe honour; in others, pride; in others, vanity. In a fenfe not decidedly bad, but rather bad than otherwife, ambition. In an indifferent fenfe, in fome cafes, the love of fame: in others, the fenfe of thame. And, as the pleafures belonging to the moral fanction run Vor. I. 
INTROD. undiftinguifhably into the pains derived from the fame fource *, it may Chap.X. alfo be ftiled, in fome cafes, the fear of difhonour, the fear of difgrace, the fear of infamy, the fear of ignominy, or the fear of thame.

r. You have received an affront from a man: according to the cuftom of the country, in order, on the one hand, to fave yourfelf from the Thame of being thought to bear it patiently ${ }^{k}$; on the other hand, to obtain the reputation of courage; you challenge him to fight with

* A man's bearing an affront patiently, that is, without taking this method of doing what is called wiping it off, is thought to import one or other of two things: either that he does not poffers that fenfibility to the pleafures and pains of the moral fanction, which, in order to render himfelf a refpectable member of fociety, a man ought to poffefs: or, that he does not poffefs courage enough to ftake his life for the chance of gratifying that refentment which a proper fenfe of the value of thofe pleafures and thofe pains it is thought would not fail to infpire. True it is, that there are divers other motives, by any of which the fame conduct might equally be produced: the motives correfponding to the religious fanction, and the motives that come under the head of benevolence. Piety towards God, the practice in quettion being generally looked upon as repugnant to the dictates of the religious fanction: fympathy for your antagonit himfelf, whofe life would be put to hazard at the fame time with your own; fympathy for his connections; the perfons who are dependent on him in the way of fupport, or connected with him in the way of fympathy : fympathy for your own connections : and even fympathy for the public, in cafes where the man is fuch that the public appears to have a material intereft in his life. But in comparifon with the love of life, the influence of the religious fanction is known to be in general but weak: efpecially among people of thofe claffes who are here in queftion: a fure proof of which is the prevalence of this very cuftom. Where it is fo frong as to preponderate, it is forare, that, perhaps, it gives a man a place in the calendar: and, at any rate, exalts him to the rank of martyr. Moreover, the inftances in which either private benevolence or public fpirit predominate over the love of life, will alfo naturally be but rare: and, owing to the general propenfity to detraction, it will alfo be much rarer for them to be thought to do fo. Now, when three or more motives, any one of them capable of producing a given mode of conduct, apply at once, that which appears to be the mont powerfil, is that which will of courfe be deemed to have actually done the moft: and, as the bulk of mankind; on this as on other ofcafions, are difpofed to decide peremptory upon fuperficial eftimates, it will generally be looked upon as having done the whole.

The confequence is, that when a man of a certain rank forbears to take this chance of revenging an affront, his conduct will, by moft people, be imputed to the love of life: which, when it predominates over the love of reputation, is, by a not unfalutary affociation of ideas, ftigmatized with the reproachful name of cowardice.

* See Chap. vi. [Pleafures and Pains.] par, xxiv, note. 


\section{of $[\mathrm{M} O \mathrm{~T}$ I $V$ E S. $]$}

mortal weapons. In this cafe your motive will by fome people be accounted laudable, and ftiled honour: by others it will be accounted blameable, and thefe, if they call it honour, will prefix an epithet of improbation to it, and call it falfe honour. 2. In order to obtain a poft of rank and dignity, and thereby to encreafe the refpects paid you by the public, you bribe the electors who are to confer it, or the judge before whom the title to it is in difpute. In this cafe your motive is commonly accounted corrupt and abominable, and is ftiled, perhaps, by fome fuch name as difhoneft or corrupt ambition, as there is no fingle name for it. 3. In order to obtain the good-will of the public, you beftow a large fum in works of private charity or public utility. In this cafe people will be apt not to agree about your motive. Your enemies will put a bad colour upon it, and call it oftentation : your friends, to fave you from this reproach, will choofe to impute your conduct not to this motive but to fome other: fuch as that of charity (the denomination in this cafe given to private fympathy) or that of public fpirit. 4. A king, for the fake of gaining the admiration annexed to the name of conqueror (we will fuppofe power and refentment out of the queftion) engages his kingdom in a bloody war. His motive, by the multitude (whofe fympathy for millions is eafily overborne by the pleafure which their imagination finds in gaping at any novelty they obferve in the conduct of a fingle perfon) is deemed an admirable one. Men of feeling and reflection, who difapprove of the dominion exercifed by this motive on this occafion, without always perceiving that it is the fame motive which in other inftances meets with their approbation, deem it an abominable one; and becaufe the multitude, who are the manufacturers of language, have not given them a fimple name to call it by, they will call it by fome fuch compound name as the love of falfe glory or falfe ambition. Yet in all four cafes the motive is the fame: it is neither more nor lefs than the love of reputation.

XXIII.

To the pleafures of power correfponds the motive which, in a neutral fenfe, may be termed the love of power. People, who are out of hu- 
criii

INTROD.

CHAP.X.

To the pleafures of

power, the

love of power.

\section{of [M O T I V E S.]}

mour with it fometimes, call it the luft of power. In a good fenfe, it is farcely provided with a name. In certain cafes this motive, as well as the love of reputation, are confounded under the fame name, ambition. This is not to be wondered at, confidering the intimate connection there is between the two motives in many cafes : fince it commonly happens, that the fame object which affords the one fort of pleafure, affords the other fort at the fame time: for inftance, offices, which are at once pofts of honour and places of truft: and fince at any rate reputation is the road to power.

I. If, in order to gain a place in adminiftration, you poifon the man who occupies it. 2. If, in the fame view, you propofe a falutary plan for the advancement of the public welfare; your motive is in both cafes the fame. Yet in the firft cafe it is accounted criminal and abominable: in the fecond cafe allowable, and even laudable.

\section{XXIV.}

To the pleafures as well as to the pains of the religious fanction correfponds a motive which has, ftrictly fpeaking, no perfectly neutral name applicable to all cafes, unlefs the word religion be admitted in this character: though the word religion, ftrictly fpeaking, feems to mean not fo much the motive itfelf, as a kind of fictitious perfonage, by whom the mative is fuppofed to be created, or an affemblage of acts, fuppofed to be dictated by that perfonage: nor does it feem to be compleatly fettled into a neutral fenfe. In the fame fenfe it is alfo, in fome cafes, ftiled religious zeal : in other cafes, the fear of God. The love of God, though commonly contrafted with the fear of God, does not come ftrictly under this head. It coincides properly with a motive of a different denomination; viz. a kind of fympathy or goodwill, which has the Deity for its object. In a good fenfe, it is ftiled devotion, piety, and pious zeal. In a bad fenfe, it is ftiled, in fome cafes, fuperftition, or fuperftitious zeal : in other cafes, fanaticifm, or fanatic zeal : in a fenfe not decidedly bad, becaufe not appropriated to this motive, enthufiafm, or enthufiaftic zeal.

I. In order to obtain the favour of the Supreme Being, a man affaffnates his lawful fovereign. In this cafe the motive is now almort univerfally 


\section{of $\left[\begin{array}{lllllll}M & O & T & I & V & E & S .\end{array}\right]$}

verfally looked upon as abominable, and is termed fanaticifm: formerly it was by great numbers accounted laudable, and was by them called pious zeal. 2. In the fame view, a man larhes himfelf with thongs. In this cafe, in yonder houfe, the motive is accounted laudable, and is called pious zeal : in the next houfe it is deemed contemptible, and called fuperftition. 3. In the fame view, a man eats a piece of bread (or at leaft what to external appearance is a piece of bread) with certain ceremonies. In this cafe, in yonder houfe, his motive is looked upon as laudable, and is ftiled piety and devotion: in the next houfe it is deemed abominable, and ftiled fuperftition, as before : perhaps even it is abfurdly ftiled impiety. 4. In the fame view, a man holds a cow by the tail while he is dying. On the Thames the motive would in this cafe be deemed contemptible, and called fuperftition. On the Ganges it is deemed meritorious, and called piety. 5. In the fame view, a man beftows a large fum in works of charity, or public utility. In this cafe the motive is ftiled laudable, by thofe at leaft to whom the works in quertion appear to come under this defcription: and by thefe at leaft it would be ftiled piety. Yet in all there cafes the motive is precifely the fame: it is neither more nor lefs than the motive belonging to the religious fanction ${ }^{3}$.

\section{$\mathrm{XXV}$.}

To the pleafures of fympathy correfponds the motive which, in a neutral fenfe, is termed good-will. The word fympathy may alfo be ufed on this occafion: though the fenfe of it feems to be rather more extenfive. In a good fenfe, it is ftiled benevolence: and in certain cafes, philanthropy; and in a figurative way, brotherly love; in others, humanity; in others, charity; in others, pity and compaffion; in

\footnotetext{
1 I am aware, or at leaft I hope, that people in general, when they fee the matter thus ftated, will be ready to acknowledge, that the motive in thefe cafes, whatever be. the tendency of the acts which it produces, is not a bad one : but this will not render it the lefs true, that hitherto, in popular difcourfe, it has been common for men to fpeak of acts, which they could not but acknowledge to have originated from this fource, as. proceeding from a bad motive. The fame obfervation will apply to many of the othes cafes.
}

Good-will, \&c. to the pleafures of fympathy. 
INTROD. others, mercy; in others, gratitude; in others, tendernefs; in others, CHAP. X. patriotifm; in others, public fpirit. Love is alfo employed in this as in fo many other fenfes. In a bad fenfe, it has no name applicable to it in all cafes: in particular cafes it is ftiled partiality. The word zeal, with certain epithets prefixed to it, might alfo be employed fometimes on this occafion, though the fenfe of it be more extenfive; applying fometimes to ill as well as to good will. It is thus we fpeak of party zeal, national zeal, and public zeal. The word attachment is alfo ufed with the like epithets: we alfo fay family-attachment. The French expreffion, efprit de corps, for which as yet there feems to be fcarcely any name in Englin, might be rendered, in fome cafes, though rather inadequately, by the terms profeffional fpirit, profeffional attachment, or profeffional zeal.

I. A man who has fet a town on fire is apprehended and committed: out of regard or compafion for him, you help him to break prifon. In this cafe the generality of people will probably fcarcely know whether to condemn your motive or to applaud it : thofe who condemn your conduct, will be difpofed rather to impute it to fome other motive: if they ftile it benevolence or compaffion, they will be for prefixing an epithet, and calling it falfe benevolence or falfe compaffion ${ }^{\mathrm{m}}$. 2. The man is taken again, and is put upon his trial : to fave him you fwear falfely in his favour. People, who would not call your motive a bad one before, will perhaps call it fo now. 3. A man is at law with you about an eftate: he has no right to it: the judge knows this, yet, having an efteem or affection for your adverfary, ad-

$m$ Among the Greeks, perhaps, the motive, and the conduct it gave birth to, would, in fuch a cafe, have been rather approved than difapproved of. It feems to have been deemed an ant of heroifm on the part of Hercules, to have delivered his friend Thefeus from hell: though divine juftice, which held him there, thould naturally have been regarded as being at leaft upon a footing with human juftice. But to divine juftice, even when acknowledged under that character, the refpect paid at that time of day does not feem to have been very profound, or well-fettled : at prefent, the refpect paid to it is profound and fettled enough, though the name of it is but too often applied to dictates which could have had no other origin than the worft fort of human caprice. 


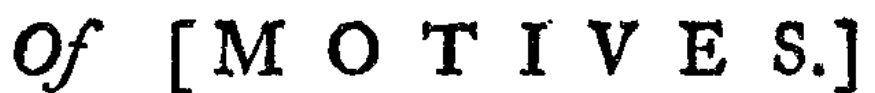

judges it to him. In this cafe the motive is by every body deemed INTROD. abominable, and is termed injuftice and partiality. 4. You detect a ftatefman in receiving bribes : out of regard to the public intereft, you give information of it, and profecute him. In this cafe, by all who acknowledge your conduet to have originated from this motive, your motive will be deemed a laudable one, and ftiled public fpirit. But his friends and adherents will not choofe to account for your conduct in any fuch manner : they will rather attribute it to party enmity. 5 . You find a man on the point of ftarving: you relieve him; and fave his life. In this cafe your motive will by every body be accounted laudable, and it will be termed compaffion, pity, charity; benevolence. Yet in all thefe cafes the motive is the fame: it is neither more nor lefs than the motive of good-will.

\section{XXVI.}

To the pleafures of malevolence, or antipathy, correfponds the motive which, in a neutral fenfe, is termed antipathy or difpleafure : and, in particular cafes, dinike, averfion, abhorrence, and indignation: in a neutral fenfe, or perhaps a fenfe leaning a little to the bad fide, ill-will: and, in particular cafes, anger, wrath, and enmity. In a bad fenfe it is ftiled, in different cafes, wrath, fpleen, ill-humour, hatred, malice, rancour, rage, fury, cruelty, tyranny, envy, jealoufy, revenge, mifanthropy, and by other names, which it is hardly worth while to endeavour to collect ${ }^{\text {. }}$. Like good-will, it is ufed with epithets expreffive of the perfons who are the objects of the affection. Hence we hear of party enmity, party rage, and fo forth. In a good fenfe there feems to be no fingle name for it. In compound expreffions it may be fpoken of in fuch a fenfe, by epithets, fuch as juft and laudable, prefixed to words that are ufed in a. neutral or nearly neutral fenfe.

"Here, as elfewhere, it may be obferved, that the fame words which are mentioned as names of motives, are alfo many of them names of paffions, appetites, and affections : fictitious entities, which are framed only by confidering pleafures or pains in fome particular point of view. Some of them are alfo names of moral qualities. This branch of nomenclature is remarkably entangled: to unravel it compleatly would take up a whole volume $;$ not a fyllable of which would belong properly to the prefent defign:

1. You:

Ill-will, \&-c. to the pleafures of antipathy. 
INTROD. 1. You rob a man: he profecutes you, and gets you punifhed: out ÇAP. $X$. of refentment you fet upon him, and hang him with your own hands. In this cafe your motive will univerfally be deemed deteftable, and will be called malice, cruelty, revenge, and fo forth. 2. A man has ftolen a little money from you : out of refentment you profecute him, and get him hanged by courfe of law. In this cafe people will probably be a little divided in their opinions about your motive: your friends will deem it a laudable one, and call it a juft or laudable refentment: your enemies will perhaps be difpofed to deem it blameable, and call it cruelty, malice, revenge, and fo forth : to obviate which, your friends will try perhaps to change the motive, and call it public fpirit. 3. A man has murdered your father: out of refentment you profecute him, and get him put to death in courfe of law. In this cafe your motive will be univerfally deemed a laudable one, and ftiled, as before, a juft or laudable refentment : and your friends, in order to bring forward the more amiable principle from which the malevolent one, which was your immediate motive, took its rife, will be for keeping the latter out of fight, fpeaking of the former only, under fome fuch name as filial piety. Yet in all thefe cafes the motive is the fame: it is neither more nor lefs than the motive of ill-will.

\section{XXVII.}

Self-prefervation, to the Ceveral kinds of pains.

To the feveral forts of pains, or at leaft to all fuch of them as are conceived to fubfift in an intenfe degree, and to death, which, as far as we can perceive, is the termination of all the pleafures, as well as all the pains we are acquainted with, correfponds the motive, which in a neutral fenfe is ftiled, in general, felf-prefervation: the defire of preferving one's felf from the pain or evil in queftion. Now in many inftances the defire of pleafure, and the fenfe of pain, run into one another undiftinguifhably. Self-prefervation, therefore, where the degree of the pain which it correfponds to is but light, will fcarcely be diftinguifhable, by any precife line, from the motives correfponding to the feveral forts of pleafures.

Thus 
Thus in the cafe of the pains of hunger and thirtt: phyfical want will in many cafes be fcarcely diftinguinable from phyfical defire. In fome cafes it is ftiled, ftill in a neutral fenfe, felf-defence. Between the pleafures and the pains of the moral and religious fanctions, and confequently of the motives that correfpond to them, as likewife between the pleafures of amity, and the pains of enmity, this want of boundaries has already been taken notice of*. The cafe is the fame between the pleafures of wealth, and the pains of privation correfponding to thofe pleafures. There are many cafes, therefore, in which it will be difficult to diftinguifh the motive of felf-prefervation from pecuniary intereft, from the defire of ingratiating one's felf, from the love of reputation, and from religious hope: in which cafes, thofe more fpecific and explicit names will naturally be preferred to this general and inexplicit one. There are alfo a multitude of compound names, which either are already in ufe, or might be devifed, to diftinguifh the fpecific branches of the motive of felf-prefervation from thofe feveral motives of a pleafurable origin: fuch as the fear of poverty, the fear of lofing fuch or fuch a man's regard, the fear of thame, and the fear of God. Moreover, to the evil of death correfponds, in a neutral fenfe, the love of life; in a bad fenfe, cowardice : which correfponds alfo to the pains of the fenfes, at leaft when confidered as fubfifting in an acute degree. There feems to be no name for the love of life that has a good fenfe; unlefs it be the vague and general name of prudence.

I. To fave yourfelf from being hanged, pilloried, imprifoned, or fined, you poifon the only perfon who can give evidence againft you. In this cafe your motive will univerfally be ftiled abominable: but as the term felf-prefervation has no bad fenfe, people will not care to make this ufe of it: they will be apt rather to change the motive, and call it malice. 2. A woman, having been juit delivered of an illegitimate child, in order to fave herfelf from thame, deftroys the child, or abandons it. In this cafe, alfo, people will call the motive a bad one, and, not caring to fpeak of it under a neutral name, they will be apt

- See ch. v. [Pleafures and Pains] par. xxiv. xxv.

Vor. I.

$Q$

to 


\section{cxiv}

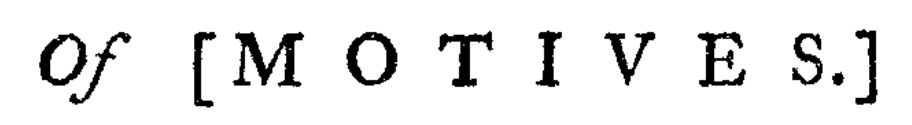

INTROD. to change the motive, and call it by fome fuch name as cruelty. 3. To

CHAP. $X$. fave the expence of a halfpenny, you fuffer a man, whom you could preferve at that expence, to perifh with want, before your eyes. In this cafe your motive will be univerfally deemed an abominable one; and, to avoid calling it by fo indulgent a name as felf-prefervation, people will be apt to call it avarice and niggardlinefs, with which indeed in this cafe it indiftinguifhably coincides: for the fake of finding a more reproachful appellation, they will be apt likewife to change the motive, and term it cruelty. 4. To put an end to the pain of hunger, you fteal a loaf of bread. In this cafe your motive will fcarcely, perhaps, be deemed a very bad one; and, in order to exprefs more indulgence for it, people will be apt to find a ftronger name for it than felf-prefervation, terming it necefity. 5. To fave yourfelf from drowning, you beat off an innocent man who has got hold of the fame plank. In this cafe your motive will in general be deemed neither good nor bad, and it will be termed felf-prefervation, or neceffity, or the love of life. 6. To fave your life from a gang of robbers, you kill them in the conflict. In this cafe the motive may, perhaps, be deemed rather laudable than otherwife, and, befides felf-prefervation, is ftiled alfo felf-defence. 7. A foldier is fent out upon a party againft a weaker party of the enemy: before he gets up with them, to fave his life, he runs away. In this cafe the motive will univerfally be deemed a contemptible one, and will be called cowardice. Yet in all thefe various cafes, the motive is ftill the fame. It is neither more nor lefs than felf-prefervation.

\section{XXVIII.}

To the pains of exertion, the love of eafe.

In particular, to the pains of exertion correfponds the motive, which, in a neutral fenfe, may be termed the love of eafe, or by a longer circumlocution, the defire of avoiding trouble. In a bad fenfe, it is termed indolence ${ }^{\circ}$. It feems to have no name that carries with it a good fenfe.

- It may feem odd at firft fight to fpeak of the love of eafe as giving birth to action : but exertion is as natural an effect of the love of eafe as inaction is, when a fmaller degree of exertion promifes to exempt a man from a greater. 


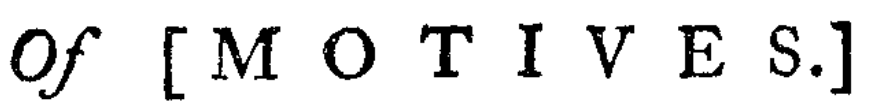

I. To fave the trouble of taking care of it, a parent leaves his child to perifh. In this cafe the motive will be deemed an abominable one, and, becaufe indolence will feem too mild a name for it, the motive will, perhaps, be changed, and fpoken of under fome fuch term as cruelty. 2. To fave yourfelf from an illegal navery, you make your efcape. In this cafe the motive will be deemed certainly not a bad one: and, becaufe indolence, or even the love of eafe, will be thought too unfavourable a name for it, it will, perhaps, be ftiled the love of liberty. 3: A mechanic, in order to fave his labour, makes an improvement in his machinery. In this cafe, people will look upon his motive as a good one; and finding no name for it that carries a good fenfe, they will be difpofed to keep the motive out of fight : they will fpeak rather of his ingenuity, than of the motive which was the means of his manifefting that quality. Yet in all thefe cafes the motive is the fame: it is neither more nor lefs than the love of eafe.

\section{XXIX.}

It appears then that there is no fuch thing as any fort of motive Motives can which is a bad one in itfelf: nor, confequently, any fuch thing as a fort only be bad of motive, which in itfelf is exclufively a good one. And as to their rence to the effects, it appears too that thefe are fometimes bad, at other times molt frequent either indifferent or good: and this appears to be the cafe with of their efevery fort of motive. If any fort of motive then is either good or bad on the fcore of its effects, this is the cafe only on individual occafions, and with individual motives; and this is the cafe with one fort of motive as well as with another. If any fort of motive then can, in confideration of its effects, be termed with any propriety a bad one, it can only be with reference to the balance of all the effects it may have had of both kinds within a given period, that is, of its moft ufual tendency.

\section{XXX.}

What then? (it will be faid) are not luft, cruelty, avarice, bad How it is that motives? Is there fo much as any one individual occafion, in which motives, fuch motives like thefe can be otherwife than bad? No, certainly: and yet rice, \&c. are the propofition, that there is no one fort of motive but what will on conflantly

$$
\text { Q2 many }
$$


INTROD. many occafions be a good one, is neverthelefs true. The fact is, CHap. X. that thefe are names which, if properly applied, are never applied but in the cafes where the motives they fignify happen to be bad. The names of thefe motives, confidered apart from their effects, are venereal defire, difpleafure, and pecuniary intereft. To venereal defire, when the effects of it are looked upon as bad, is given the name of luft. Now luft is always a bad motive. Why? Becaufe if the cafe be fuch, that the effects of the motive are not bad, it does not go, or at leaft ought not to go, by the name of luft. The cafe is, then, that when I fay "Luft is a bad motive," it is a propofition that merely concerns the import of the word luft; and which would be falfe if transferred to the other word ufed for the fame motive, venereal defire. Hence we fee the emptinefs of all thofe rhapfodies of common-place morality, which confift in the taking of fuch names as luft, cruelty, and avarice, and branding them with marks of reprobation: applied to the tbing, they are falfe; applied to the name, they are true indeed, but nugatory. Would you do a real fervice to mankind? fhew them the cafes in which venereal defire merits the name of luft; difpleafure, that of cruelty; and pecuniary intereft, that of avarice.

\section{XXXI.}

Under the above reftrictives may be diftinguifhed into good,

bad, and indifferent or neutral.
If it were neceffary to apply fuch denominations as good, bad, and indifferent to motives, they might be claffed in the following manner, in confideration of the moft frequent complexion of their effects. In the clafs of good motives might be placed the articles of, r. Goodwill. 2. Love of reputation. 3. Defire of amity. And, 4. Religion. In the clafs of bad motives, 5. Difpleafure. In the clafs of neutral or indifferent motives, 6. Phyfical defire. 7. Pecuniary intereft. 8. Love of power. 9. Self-prefervation; as including the fear of the pains of the fenfes, the love of eafe, and the love of life.

\section{XXXII.}

Inconvenien- This method of arrangement, however, cannot but be imperfect; ces of this
dittribution. and the nomenclature belonging to it is in danger of being fallacious. For by what method of inveftigation can a man be affured, that with regard to the motives ranked under the name of good, the good effects 


\section{of $[\mathrm{M} O \mathrm{O}$ T I V $\mathrm{V}$ E S. $]$}

they have had, from the beginning of the world, have, in each INTROD. of the four fpecies comprifed under this name, been fuperior to the bad? Atill more difficulty would a man find in affuring himfelf, that with regard to thofe which are ranked under the name of neutral or indifferent, the effects they have had have exactly balanced each other, the value of the good being neither greater nor lefs than that of the bad. It is to be confidered, that the interefts of the perfon himfelf can no more be left out of the eftimate, than thofe of the reft of the community. For what would become of the fpecies, if it were not for the motives of hunger and thirft, venereal defire, the fear of pain, and the love of life? Nor in the actual conftitution of human nature is the motive of difpleafure lefs neceffary, perhaps, than any of the others: although a fyftem, in which the bufinefs of life might be carried on without it, might poffibly be conceived. It feems, therefore, that they could fcarcely, without great danger of miftakes, be diftinguifhed in this manner even with reference to each other.

\section{XXXIII.}

The only way, it hould feem, in which a motive can with fafety and propriety be ftiled good or bad, is with reference to its effects in each individual inftance; and principally from the intention it gives birth to: from which arife, as will be fhewn hereafter, the moft material It is only in indiviưuài inftances that motives can be good or part of its effects. A motive is good, when the intention it gives birth to is a good one; bad, when the intention is a bad one: and an intention is good or bad, according to the material confequences that are the objects of it. So far is it from the goodnefs of the intention's being to be known only from the fpecies of the motive. But from one and the fame motive, as we have feen, may refult intentions of every fort of complexion whatfoever. This circumftance, therefore, can afford no clue for the arrangement of the feveral forts of motives.

\section{XXXIV.}

A more commodious method, therefore, it fhould feem, would be Motives difto diftribute them according to the influence which they appear to tinguifhed have on the interefts of the other members of the community, laying into focial, thofe of the party himfelf out of the queftion: to wit, according to felf-regardthe of the party himfelf out of the queftion : to wit, according to the tendency which they appear to have to unite, or difunite, his inzerefts 
INTROD, and theirs. On this plan they may be diftinguifhed into focial, difCHA . X. Social, and felf-regarding. In the focial clafs may be reckoned, 1 . Goodwill. 2. Love of reputation. 3. Defire of amity. 4. Religion. In the diffocial may be placed, 5. Difpleafure. In the felf-regarding clafs, 6. Phyfical defire. 7. Pecuniary intereft. 8. Love of power. 9. Selfprefervation; as including the fear of the pains of the fenfes, the love of eate, and the love of life.

\section{XXXV.}

-focial, into With refpect to the motives that have been termed focial, if any

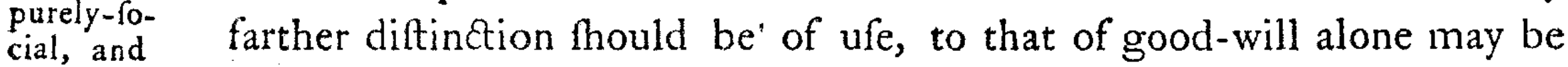
femi-focial. applied the epithet of purely-focial; while the love of reputation, the defire of amity, and the motive of religion, may together be comprifed under the divifion of femi-focial: the focial tendency being much more conftant and unequivocal in the former than in any of the three latter. Indeed thefe laft, focial as they may be termed, are felf-regarding at the fame time ${ }^{p}$.

\section{$\$ 4$. Order of pre-eminence among motives.}

\section{XXXVI.}

The distates of good-will are the fureft of coinciding with thofe of utility.

Of all thefe forts of motives, good-will is that of which the dictates ${ }^{q}$, taken in a general view, are fureft of coinciding with thofe of the principle of utility. For the dictates of utility are neither more nor lefs than the dictates of the moft extenfive * and enlightened (that is welladvifed + ) benevolence. The dictates of the other motives may be conformable to thofe of utility, or repugnant, as it may happen.

\section{XXXVII.}

Yet do not in In this, however, it is taken for granted, that in the cafe in queftion all cafes. the diftates of benevolence are not contradicted by thofe of a more ex-

\footnotetext{
$p$ " Religion," fays the pious Addifon, fomewhere in the Spectator, "is the higheft
} "s fpecies of felf-love."

q When a man is fuppofed to be prompted by any motive to engage, or not to engage, in fuch or fuch an action, it may be of ufe, for the convenience of difcourfe, to fpeak of fuch motive as giving birth to an imaginary kind of law or dictate, injoining him to engage, or not to engage, in it $\neq$.

* See ch. iv. [Value] and ch. vi. [Senfibility] xxi. + See ch. ix. [Confcioufnefs.] $\ddagger$ See $\mathrm{ch}, \mathrm{i}$. 
tenfive, that is enlarged, benevolence. Now when the dictates of INTROD. benevolence, as refpecting the interefts of a certain fet of perfons, are $\mathrm{C}_{\text {HAP. }} \mathrm{X}$. repugnant to the dictates of the fame motive, as refpecting the more important ${ }^{*}$ interefts of another fet of perfons, the former dictates, it is evident, are repealed, as it were, by the latter: and a man, were he to be governed by the former, could fcarcely, with propriety, be faid to be governed by the dictates of benevolence. On this account, were the motives on both fides fure to be alike prefent to a man's mind, the cafe of fuch a repugnancy would hardly be worth diftinguifhing, fince the partial benevolence might be confidered as fwallowed up in the more extenfive: if the former prevailed, and governed the action, it muft be confidered as not owing its birth to benevolence, but to fome other motive: if the latter prevailed, the former might be confidered as having no effect. But the cafe is, that a partial benevolence may govern the action, without entering into any direct competition with the more extenfive benevolence, which would forbid it; becaufe the interefts of the lefs numerous affemblage of perfons may be prefent to a man's mind, at a time when thofe of the more numerous are either not prefent, or, if prefent, make no impreffion. It is in this way that the dictates of this motive may be repugnant to utility, yet ftill be the dictates of benevolence. What makes thofe of private benevolence conformable upon the whole to the principle of utility, is, that in general they ftand unoppofed by thofe of public: if they are repugnant to them, it is only by accident. What makes them the more conformable, is, that in a civilized fociety, in moft of the cafes in which they would of themfelves be apt to run counter to thofe of public benevolence, they find themfelves oppofed by ftronger motives of the felf-regarding clars, which are played off againft them by the laws; and that it is only in cafes where they ftand unoppofed by the other more falutary dictates, that they are left free. An act of injuftice or cruelty, committed by a man for the fake of his father or his fon, is punifhed, and with reafon, as much as if it were committed for his own.

* or valuable. See ch, iv, [Value.]

XXXVIIr. After 
After good-will, the motive of which the dictates feem to have the Next to them next beft chance for coinciding with thofe of utility, is that of the love
come thofe of the love of of reputation. There is but one circumftance which prevents the reputation. dictates of this motive from coinciding in all cales with thofe of the former. This is, that men in their likings and dinikings, in the difpofitions they manifeft to annex to any mode of conduct their approbation or their difapprobation, and in confequence to the perfon who appears to practife it, their good or their ill will, do not govern themfelves exclufively by the principle of utility. Sometimes it is the principle of afceticifm they are guided by: fometimes the principle of fympathy and antipathy. There is another circumftance, which diminifhes, not their conformity to the principle of utility, but only their efficacy in comparifon with the dictates of the motive of benevolence. The dietates of this motive will operate as ftrongly in fecret as in public: whether it appears likely that the conduct which they recommend will be known or not: thofe of the love of reputation will coincide with thofe of benevolence only in proportion as a man's conduct feems likely to be known. This circumftance, however, does not make fo much difference as at firft fight might appear. Acts, in proportion as they are material, are apt to become known *: and in point of reputation, the lighteft fufpicion often ferves for proof. Befides, if an act be a difreputable one, it is not any affurance a man can have of the fecrecy of the particular act in queftion, that will of courfe furmount the objections he may have againf engaging in it. Though the act in queftion thould remain fecret, it will go towards forming a habit, which may give birth to other acts, that may not meet with the fame good fortune. There is no human being, perhaps, who is at years of difcretion, on whom confiderations of this fort have not forme weight: and they have the more weight upon a man, in proportion to the ftrength of his intellectual powers, and the firmnefs of his mind $t$. Add to this, the influence which habit itfelf, when once

- See B. II. tit. [Evidence.]

† See ch. vi. [Senfibility] par. xii. xiii.

formed, 
formed, has in reftraining a man from acts towards which, from the view: of the difrepute annexed to them, as well as from any other caufe, he has contracted an averfion. The influence of habit, in fuch cafes, is a matter of fact, which, though not readily accounted for, is acknowledged and indubitable r.

\section{XXXIX.}

After the dictates of the love of reputation come, as it fhould feem, thofe of the defire of amity. The former are difpofed to coincide with thofe of utility, inafmuch as they are difpofed to coincide with thofe of benevolence. Now thofe of the defire of amity are apt alfo to coincide, in a certain fort, with thofe of benevolence. But the fort of benevolence with the dictates of which the love of reputation coincides, is the more extenfive; that with which thofe of the defire of amity coincide, the lefs extenfive. Thofe of the love of amity have ftill, however, the advantage of thofe of the felf-regarding motives. The former, at one period or other of his life, difpore a man to contribute to the happinefs of a confiderable number of perfons: the latter, from the beginning of life to the end of it, confine themfelves to the care of that fingle individual. The dictates of the defire of amity, it is plain, will approach nearer to a coincidence with thofe of the love of reputation, and thence with thofe of utility, in proportion, ceteris paribus, to the number of the perfons whofe amity a man has occafion to defire: and hence it is, for example, that an Englifh member of parliament, with all his own weakneffes, and all the follies of the people whofe amity he has to cultivate, is probably, in general, a better character than the fectetary of a vifier at Conftantinople, or of a naïb in Indoftan.

\section{XL.}

The dictates of religion are, under the infinite diverfity of religions, fo extremely variable, that it is difficult to know what general account

\section{Next thofe of the defire of amity.}

\footnotetext{
- Strictly fpeaking, habit, being but a ficitious entity, and not really any thing diftinet from the aets or perceptions by which it is faid to be formed, cannot be the caufe of any thing. The enigma, however, may be fatisfactorily folved upon the principle of afociation, of the nature and force of which a very fatisfactory account may be feen in Dr. Priefly's edition of Hartley on Man.
}

Vor. I. 
INTROD. to give of them, or in what rank to place the motive they belong to. СнA. X. Upon the mention of religion, people's firft thoughts turn naturally to the religion they themfelves profefs. This is a great fource of mifcalculation, and has a tendency to place this fort of motive in a higher rank than it deferves. The dictates of religion would coincide, in all cafes, with thofe of utility, were the Being, who is the object of religion, univerfally fuppofed to be as benevolent as he is fuppofed to be wife and powerful; and were the notions entertained of his benevolence, at the fame time, as correet as thofe which are entertained of his wifdom and his power. Unhappily, however, neither of thefe is the cafe. $\mathrm{He}$ is univerfally fuppofed to be all-powerful : for by the Deity, what elfe does any man mean than the Being, whatever he be, by whom every thing is done? And as to knowledge, by the fame rule that he fhould know one thing he fhould know another. Thefe notions feem to be as correct, for all material purpofes, as they are univerfal. But among the votaries of religion (of which number the multifarious fraternity of Chriftians is but a fmall part) there feem to be but few (I will not fay how few) who are real believers in his benevolence. They call him benevolent in words, but they do not mean that he is fo in reality. They do not mean, that he is benevolent as man is conceived to be benevolent: they do not mean that he is benevolent in the only fenfe in which benevolence has a meaning. For if they did, they would recognize that the dictates of religion could be neither more nor lefs than the dictates of utility: not a tittle different: not a tittle lefs or more. But the cafe is, that on a thoufand occafions, they turn their backs on the principle of utility. They go attray after the Atrange principles its antagonifts: fometimes it is the principle of afceticifm: fometimes the principle of fympathy and antif $y^{*}$. Accordingly, the idea they bear in their minds, on fuch occafions, is but too often the idea of malevolence; to which idea, ftripping it of its own proper name, they beftow the fpecious appellation of the focial motives. The dictates of religion, in thort,

- Ch. ii. [Principles Adverfe] xviii.

are

- Sometimes, in order the better to conceal the cheat (from their own eyes doubtlefs as well as from others) they fet up a phantom of their own, which they call Juftice: 


\section{of $\left[\begin{array}{lllllll}M & O & T & I & V & E & S .\end{array}\right]$}

cxxiii

are no other than the dictates of that principle which has been already mentioned under the name of the theological principle*. Thefe, as has been obferved, are juft as it may happen, according to the biafes of the perfon in queftion, copies of the dictates of one or other of the three original principles: fometimes, indeed, of the dictates of utility : but frequently of thofe of afceticifm, or thofe of fympathy and antipathy. In this refpect they are only on a par with the dictates of the love of reputation: in another they are below it. The dictates of religion are in all places intermixed more or lefs with dictates unconformable to thofe of utility, deduced from texts, well or ill interpreted, of the writings held for facred by each fect: unconformable, by impofing practices fometimes inconvenient to a man's felf, fometimes pernicious to the reft of the community. The fufferings of uncalled martyrs, the calamities of holy wars and religious perfecutions, the mifchiefs of intolerant laws, (objects which can here only be glanced at, not detailed) are fo many additional mifchiefs over and above the number of thofe which were ever brought into the world by the love of reputation. On the other hand, it is manifeft, that with refpect to the power of operating in fecret, the dictates of religion have the fame advantage over thofe of the love of reputation, and the defire of amity, as is poffeffed by the dictates of benevolence.

\section{XLI.}

Happily, the dictates of religion feem to approach nearer and nearer to a coincidence with thofe of utility every day. But why? Becaufe the dietates of the moral fanction do fo: and thofe coincide with or are influenced by thefe. Men of the wort religions, influenced by the voice and practice of the furrounding world, borrow continually a new

whofe diktates are to modify (which being explained, means to oppofe) the diEtates of benevolence. But juftice, in the only fenfe in which it has a meaning, is an imaginary perfonage, feigned for the convenience of difcourfe, whofe dictates are the diftates of utility, applied to certain particular cafes. Juftice, then, is nothing more than an imaginary inftrument, employed to forward on certain occafions, and by certain means, the purpofes of benevolence. The diftates of juftice are nothing more than a part of the dictates of benevolence, which, on certain occafions, are applied to certain fubjects; to wit, to certain actions.

- See ch, ii. [Principles Adverfe, \&c.] 
INTROD. and a new leaf out of the book of utility: and with thefe, in order not CHAP. X. to break with their religion, they endeavour, fometimes with violence enough, to patch together and adorn the repofitories of their faith.

\section{XLII.}

Afterwards come the felf regarding motives: and, laftly, that of difpleafure.

As to the felf-regarding and dif-focial motives, the order that takes place among thefe, and the preceding one, in point of extra-regarding influence; is too evident to need infifting: on. As to the order that takes place among the motives of the felf-regarding clafs, confidered in comparifon with one another, there feems to be no difference which on this occafion would be worth mentioning: With refpeet to the diffocial motive, it makes a difference (with regard to its extra-regarding effects) from which of two fources it originates; whether from felfregarding or from focial confiderations. The difpleafure you conceive againft a man may be founded either on fome act which offends you in the firft inftance, or on an act which offends you no otherwife than becaufe you look upon it as being prejudicial to fome other party on whofe behalf you intereft yourfelf: which other party may be of courfe either a determinate individual, or any affemblage of individuals, determinate or indeterminate ${ }^{*}$. It is obvious enough, that a motive, though in itfelf diffocial, may, by iffuing from a focial origin, poffefs-a focial tendency; and that its tendency, in this cafe, is likely to be the more focial, the more enlarged the defcription is of the perfons whofe interefts you efpoufe. Difpleafure, venting itfelf againft a man, on account of a mifchief fuppofed to be done by him to the public, may be more focial in its effects than any good-will, the exertions of which are confined to an individual $t$.

\section{\$. Conflizt among motives.}

\section{XLIII.}

Motives inpelling and reftraining, what.

When a man has it in contemplation to engage in any action, he is frequently acted upon at the fame time by the force of divers motives : one motive, or fet of motives, acting in one direction; another motive, or fet of motives, acting as it were in an oppofite direction. The motives on one fide difpofing him to engage in the action: thofe

\footnotetext{
- See ch, vi. [Senfibility] par. xxi.
} + See Jupra, par. xxxvii. 
on the other, difpofing him not to engage in it. Now, any mo- INTROD. tive, the influence of which tends to difpofe him to engage in the action in queftion, may be termed an impelling motive: any motive, the influence of which tends to difpofe him not to engage in it, a. reftraining motive. But thefe appellations may of courfe be interchanged, according as the act is of the pofitive kind, or the negative.*.

XLIV.

It has been thewn, that there is no fort of motive but may give What are the birth to. any fort of action. It follows, therefore, that there are no motives moft two motives but may come to be oppofed to one another. Where the variance. tendency of the act is bad, the moft common cafe is for it to have been dictated by a motive either of the felf-regarding, or of the diffocial clafs. In fuch cafe the motive of benevolence has commonly been acting, though ineffectually, in the character of a reftraining motive.

\section{XLV.}

An example may be of ufe, to fhew the variety of contending mo- Example to tives, by which a man may be acted upon at the fame time. Crillon, illufrate a a Catholic (at a time when it was generally thought meritorious among among conCatholics to extirpate Proteftants) was ordered by his king, Charles IX. tending moof France, to fall privately upon Coligny, a Proteftant, and affaffinate him : his anfwer was, "Excufe me, Sire; but I'll fight him with all " my heart" ". Here then, were all the three forces above mentioned, including that of the political fanction, acting upon him at once. By the political fanction, or at leaft fo much of the force of it as fuch a mandate, from fuch a fovereign, iffued on fuch an occafion, might be fuppofed to carry with it, he was enjoined to put Coligny to death in the way of affaffination: by the religious fanction, that is, by the dictates of religious zeal, he was enjoined to put him to death in any way: by the moral fanction, or in other words, by the dictates of honour, that is, of the love of reputation, he was permitted (which permiffion, when

- See ch. vii. [Actions] par. viii.

- The idea of the cafe here fuppofed is taken from an ancedote in real hiftory, but varies from it in feveral particulars. 
INTROD. coupled with the mandates of his fovereign, operated, he conceived, as Cuar.X. an injunction) to fight the adverfary upon equal terms: by the dictates of enlarged benevolence (fuppofing the mandate to be unjuftifiable) he was enjoined not to attempt his life in any way, but to remain at peace with him: fuppofing the mandate to be unjuftifiable, by the dictates of private benevolence, he was enjoined not to meddle with him at any rate. Among this confufion of repugnant dictates, Crillon, it feems, gave the preference, in the firft place, to thofe of honour : in the next place, to thofe of benevolence. He would have fought, had his offer been accepted; as it was not, he remained at peace.

Here a multitude of queftions might arife. Suppofing the diftates of the political fanction to follow the mandate of the fovereign, of what kind were the motives which they afforded him for compliance? The anfwer is, of the felf-regarding kind at any rate: inafmuch as, by the fuppofition, it was in the power of the fovereign to punifh him for noncompliance, or reward him for compliance. Did they afford him the motive of religion? (I mean independently of the circumftance of herefy above-mentioned) the anfwer is, Yes, if his notion was, that it was God's pleafure he Thould comply with them: No, if it was not. Did they afford him the motive of the love of reputation? Yes, if it was his notion that the world would expect and require that he fhould comply with them: No, if it was not. Did they afford him that of benevolence? Yes, if it was his notion that the community would upon the whole be the better for his complying with them: No, if it was not. But did the dictates of the political fanction, in the cafe in queftion, actually follow the mandate of the fovereign: in other words, was fuch a mandate legal ? This we fee is a mere queftion of local jurifprudence, altogether foreign to the prefent purpofe.

XLVI.

Practical ufe of the above difquifitions relative to motives.
What is here faid about the goodnefs and badnefs of motives, is far. from being a mere matter of words. There will be occafion to make ufe of it hereafter for various important purpofes. I thall have need of it for the fake of diffipating various prejudices, which are of differvice to the community, fometimes by cherifhing the flame of civil 
diffenfions $*$, at other times, by obftructing the courfe of juftice. It INTROD. will be hewn, that in the cafe of many offences $t$, the confideration of Cha $\mathrm{X}$. the motive is a moft material one: for that in the firft place it makes a very material difference in the magnitude of the mifchief $\ddagger$ : in the next place, that it is eafy to be afcertained; and thence may be made a ground for a difference in the demand for punifhment: but that in other cafes it is altogether incapable of being afcertained; and that, were it capable of being ever fo well afcertained, good or bad, it could make no difference in the demand for punifhment: that in all cafes, the motive that may happen to govern a profecutor, is a confideration totally immaterial : whence may be feen the mifchievoufnefs of the prejudice that is fo apt to be entertained againft informers; and the confequence it is of that the judge, in particular, hould be proof againft the influence of fuch delufions.

Laftly, The fubject of motives is one with which it is neceffary to. be acquainted, in order to pafs a judgment on any means that may be propofed for combating offences in their fource $\|$.

But before the theoretical foundation for thefe practical obfervations can be compleatly laid, it is neceffary we thould fay fomething on the fubject of difpofition: which, accordingly, will furnifh matter for the enfuing chapter.

* See B, I. tit. [Rebellion.] $\ddagger$ See ch. xi. [Difpofitions.]
+ Ib. tit. [Simp. corp. injuries.] Ib. tit. [Homicide.] II See Append. tit. [Preventive inftitutions.] 
INTROD.

Chap. XI.

C $\mathrm{H}$ A P. XI.

I.

Difpofition, $\mathrm{N}$ the foregoing chapter it has been hewn at large, that goodnefs or what. badnefs cannot, with any propriety, be predicated of motives. Is there nothing then about a man that can properly be termed good or bad, when, on fuch or fuch an occafion, he fuffers himfelf to be governed by fuch or fuch a motive? Yes, certainly : his difpofition. "Now difpofition is a kind of fictitious entity, feigned for the convenience of difcourfe, in order to exprefs what there is fuppofed to be permanent in a man's frame of mind, where, on fuch or fuch an occafion, he has been influenced by fuch or fuch a motive, to engage in an act, which, as it appeared to him, was of fuch or fuch a tendency.

II.

-how far it It is with difpofition as with every thing elfe: it will be good or belongs to
the prefent bad according to its effects : according to the effects it has in augrubject. menting or diminifhing the happiners of the community. A man's difpofition may accordingly be confidered in two points of view: according to the influence it has, either, I. on his own happinefs : or, 2. on the happinefs of others. Viewed in both thefe lights together, or in either of them indifcriminately, it may be termed, on the one hand, good; on the other, bad; or, in flagrant cafes, depraved ${ }^{2}$. Viewed in the former of thefe lights, it has fcarcely any peculiar name, which has as yet been appropriated to it. It might be termed, though but inexpreffively, frail or infirm, on the one hand: found or firm, on the other. Viewed in

2 It might alfo be termed virtuous, or vicious. The only objection to the ufe of thofe terms on the prefent occafion is, the great quantity of good and bad repute that refpectively ftand annexed to them. The inconvenience of this is, their being apt to annex an ill-proportioned meafure of difrepute to difpofitions which are ill conftituted only with refpect to the party himfelf : involving them in fuch a degree of ignominy as thould be appropriated to fuch difpofitions only as are mifchievous with regard to others. To exalt weakneffes to a level with crimes, is a way to diminifh the abhorrence which ought to be referved for crimes. To exalt fmall evils to a level with great ones, is the way to diminith the hare of attention which ought to be paid to great ones. 


\section{of buman [D I S P O S I T I O N S] in general.}

the other light, it might be termed beneficent, or meritorious, on the one hand: pernicious or mifchievous on the other. Now of that branch of a man's difpofition, the effects of which regard in the firft inftance only himfelf, there needs not much to be faid here. To reform it when bad, is the bufinefs rather of the moralift than the leginator: nor is it fufceptible of thore various modifications which make fo material a difference in the effects of the other. Again, with refpect to that part of it, the effects whereof regard others in the firft inftance, it is only in as far as it is of a mifchievous nature that the penal branch of law has any immediate concern with it: in as far as it may be of a beneficent nature, it belongs to a hitherto but little cultivated, and as yet unnamed branch of law, which might be ftiled the remuneratory.

III.

A man then is faid to be of a mifchievous difpofition, when, by the A mifchieinfluence of no matter what motives, he is prefumed to be more apt vous difpofito engage, or form intentions of engaging, in acts which are appa- torious difrently of a pernicious tendency, than in fuch as are apparently of a be- pofition: neficial tendency: of a meritorious or beneficent difpofition in the oppofite cafe.

\section{IV.}

I fay prefumed : for, by the fuppofition, all that appears is one fingle action, attended with one fingle train of circumftances : but from that degree of confiftency and uniformity which experience has thewn to be obfervable in the different actions of the fame perfon, the probable exiftence (paft or future) of a number of acts of a fimilar nature, is naturally and juftly inferred from the obfervation of one fingle one. Under fuch circumftances, fuch as the motive proves to be in one inftance, fuch is the difpofition to be prefumed to be in others.

\section{$\mathrm{V}$.}

I fay apparently mifchievous: that is, apparently with regard to him: It depends fuch as to him appear to poffefs that tendency: for from the mere upon what fuch act apevent, independent of what to him it appears before-hand likely to be, pears to be to nothing can be inferred on either fide. If to him it appears likely to 
INTROD. be mifchievous, in fuch cafe, though in the upfhot it thould prove innoСнат. XI. cent, or even beneficial, it makes no difference; there is not the lefs reafon for prefuming his difpofition to be a bad one: if to him it appears likely to be beneficial or innocent, in fuch cafe, though in the uphot it fhould prove pernicious, there is not the more reafon on that account for prefuming his difpofition to be a good one. And here we fee the importance of the circumftances of intentionality ${ }^{*}$, confcioufnefs $t$, unconfcioufnefs $\dagger$, and mif-fuppofal $\dagger$.

\section{VI.}

Which pofi- The truth of thefe pofitions depends upon two others, both of them tion is grounded on two facts : 1. The correfpondence between intentions and confequences: fufficiently verified by experience: The one is, that in the ordinary courfe of things the confequences of actions commonly turn out conformable to intentions. A man who fets up a butcher's hop, and deals in beef, when he intends to knock down an ox, commonly does knock down an ox; though by fome unlucky accident he may chance to mifs his blow and knock down a man: he who fets up a grocer's thop, and deals in fugar, when he intends to fell fugar, commonly does. fell fugar: although by fome unlucky accident he may chance to fell arfenic in the room of it.

\section{VII.}

2. Between the intentions of the fame perfon at dif ferent times.

The other is, that a man who entertains intentions of doing mifchief at one time is apt to entertain the like intentions at another ${ }^{\circ}$.

$$
\text { - See ch. viii. } \quad+\text { See ch. ix. }
$$

A difpofition, from which proceeds a habit of doing mifchief, sood one.

b To fuppofe a man to be of a good difpofition, and at the fame time likely, in virtue of that very difpofition, to engage in an habitual train of mifchievous actions, is a contradiction in terms: nor could fuch a propofition ever be advanced, but from the giving, to the thing which the word difpofition is put for, a reality which does not belong to it. If then, for example, a man of a religious difpofition fiould, in virtue of that very difpofition, be in the habit of doing mifchief, for inftance, by perfecuting his neighbours, the cafe muft be, either that his difpofition, though good in certain refpects, is not good upon the whole : or that a religious difpofition is not in general a good one.

VIII. There 


\section{Of buman [D IS P O S I T I O N S] in general.}

\section{VIII.}

INTROD.

There are two circumftances upon which the nature of the difpofition, as indicated by any act, is liable to depend: $\mathbf{I}$. The apparent tendency of the act: 2. The nature of the motive which gave birth to it. This dependency is fubject to different rules, according to the nature of the motive. In ftating them, I fuppofe all along the apparent tendency of the act to be, as it commonly is, the fame as the real.

\section{IX.}

1. Where the tendency of the act is good, and the motive is of the self-regarding kind. In this cafe the motive affords no inference on either fide. It affords no indication of a good difpofition : but neither does it afford any indication of a bad one.

A baker fells his bread to a hungry man who anks for it. This, we fee, is one of thofe acts of which, in ordinary cafes, the tendency is unqueftionably good. The baker's motive is the ordinary commercial motive of pecuniary intereft. It is plain, that there is nothing in the tranfaction, thus ftated, that can afford the leaft ground for prefuming that the baker is a better or a worfe man than any of his neighbours.

$\mathrm{X}$.

2. Where the tendency of the act is bad, and the motive, as before, is of the felf-regarding kind. In this cafe the difpofition indicated is a mifchievous one.

A man fteals bread out of a baker's hop: this is one of thofe acts of which the tendency will readily be acknowledged to be bad. Why, and in what refpects it is fo, will be ftated farther on *. His motive, we will fay, is that of pecuniary intereft; the defire of getting the value of the bread for nothing. His difpofition, accordingly, appears to be a bad one: for every one will allow a thievin difpofition to be a bad one.

\section{$\mathrm{XI}$.}

3. Where the tendency of the act is good, and the motive is the purely focial one of good-will. In this cafe the difpofition indicated is a beneficent one.

Cafe 2. Tendency, badmotive, felfregarding.

* See ch. xii. [Confequences] and Code, B. I. tit. [Theft.]

Cafe I. Tendency, good-
motive, felfregarding.

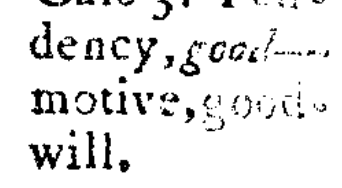




\section{cxxxii of buman [D IS POS I T ION S] in general.}

INTROD. A baker gives a poor man a loaf of bread. His motive is comCHA . XI. paftion; a name given to the motive of benevolence, in particular cafes of its operation. The difpofition indicated by the baker, in this cafe, is fuch as every man will be ready enough to acknowledge to be a good one.

\section{XII.}

Care 4. Tèndency, badmotive,goodwill.

4. Where the tendency of the act is bad, and the motive is the purely focial one of good-will. Even in this cafe the difpofition which the motive indicates is dubious: it may be a mifchievous or a meritorious one, as it happens; according as the mifchievoufnefs of the act is more or lefs apparent.

XIII.

This cafe not an impoffible one.

It may be thought, that a cafe of this fort cannot exift; and that to fuppofe it, is a contradiction in terms. For the act is one, which, by the fuppoficion, the agent knows to be a mifchievous one. How then can it be, that good-will, that is, the defire of doing good, could have been the motive that led him into it? To reconcile this, we muft advert to the diftinction between enlarged benevolence and confined ${ }^{*}$. The motive that led him into it, was that of confined benevolence. Had he followed the dictates of enlarged benevolence, he would not have done what he did. Now, although he followed the dictates of that branch of benevolence, which in any fingle inftance of its exertion is mifchievous, when oppofed to the other, yet, as the cafes which call for the exertion of the former are, beyond comparifon, more numerous than thofe which call for the exertion of the latter, the difpofition indicated by him, in following the impulfe of the former, will often be fuch as in a man, of the common run of men, may be allowed to be a good one upon the whole.

\section{XIV.}

Example I. A man with a numerous family of children, on the point of ftarving, goes into a baker's hop, fteals a loaf, divides it all among the children, referving none of it for himfelf. It will be hard to infer that that man's difpofition is a mifchievous one upon the whole. Alter the cafe,

- See ch. x. [Motives.] 


\section{Of buman [D I S P O S I T I O N S] in general.}

give him but one child, and that hungry perhaps, but in no imminent danger of ftarving: and now let the man fet fire to a houfe full of people, for the fake of ftealing money out of it to buy the bread with. The difpofition here indicated will hardly be looked upon as a good one.

$$
\mathrm{XV} \text {. }
$$

Another cafe will appear more dificult to decide than either. Ra- Example II. vaillac affaffinated one of the beft and wifeft of fovereigns, at a time when a good and wife fovereign, a bleffing at all times fo valuable to a ftate, was particularly precious: and that to the inhabitants of a populous and extenfive empire. He is taken, and doomed to the moft excruciating tortures. His fon, well perfuaded of his being a fincere penitent, and that mankind, in cafe of his being at large, would have nothing more to fear from him, effectuates his efcape: Is this then a fign of a good difpofition in the fon, or of a bad one? Perhaps fome will anfwer, of a bad one; for, befides the intereft which the nation has in the fufferings of fuch a criminal, on the fcore of the example, the future good behaviour of fuch a criminal is more than any one can have fufficient ground to be perfuaded of.

XVI.

Well then, let Ravaillac, the fon, not facilitate his father's efcape ; but Example III. content himfelf with conveying poifon to him, that at the price of an eafier death he may efcape his torments. The decifion will now, perhaps, be more difficult. The act is a wrong one, let it be allowed, and fuch as ought by all means to be punined: but is the difpofition manifefted by it a bad one? Becaufe the young man breaks the laws in this one inftance, is it probable, that if let alone, he would break the laws in ordinary inftances, for the fatisfaction of any inordinate defires of his own? The anfwer of moft men would probably be in the negative.

XVII.

5. Where the tendency of the act is good, and the motive is a femifocial one, the love of reputation. In this cafe the difpofition indicated is a good one.

Cafe 5. Tendency, goodmotive, love of reputation. 
INTROD. In a time of fcarcity, a baker, for the fake of gaining the efteem of CHAP. XI. the neighbourhood, diftributes bread gratis among the induftrious poor. Let this be taken for granted: and let it be allowed to be a matter of uncertainty, whether he had any real feeling for the fufferings of thofe whom he has relieved, or no. His difpofition, for all that, cannot, with any pretence of reafon, be termed otherwife than a good and beneficent one. It can only be in confequence of fome very idle prejudice, if it receives a different name ${ }^{c}$.

XVIII.

Cafe 6. Tendency, badmotive, honour.

The bulk of mankind apt to motive.
6. Where the tendency of the act is bad, and the motive, as before, is a femi-focial one, the love of reputation. In this cafe, the difpofition which it indicates is more or lefs good or bad: in the firft place, according as the tendency of the act is more or lefs mifchievous : in the next place, according as the dictates of the moral fanction, in the fociety in queftion, approach more or lefs to a coincidence with thofe of utility. It does not feem probable, that in any nation, which is in a

c The bulk of mankind, ever ready to depreciate the character of their neighbours, in order, indirectly, to exalt their own, will take occafion to refer a motive to the clafs of bad ones as often as they can find one ftill better, to which the act might have owed its birth. Confcious that his own motives are not of the beft clafs, or perfuaded that if they be, they will not be referred to that clafs by others; afraid of being taken for a dupe, and anxious to thew the reach of his penetration; each man takes care, in the firft place, to impute the conduct of every other man to the leaft laudable of the motives that can account for it: in the next place, when he has gone as far that way as he can, and cannot drive down the individual motive to any lower clafs, he changes his battery, and attacks the very clafs itfelf. To the love of reputation he will accordingly give a bad name upon every occafion, calling it oftentation, vanity, or vain-glory.

Partly to the fame fpirit of detraction, the natural confequence of the fenfibility of men to the force of the moral fanction, partly to the infuence of the principle of afceticifm, may, perhaps, be imputed the great abundance of bad names of motives, in comparifon of fuch as are good or neutral : and, in particular, the total want of neutral names for the motives of venereal defire, phyfical defire in general, and pecuniary intereft. The fuperior abundance, even of good names, in comparifon of neutral ones, would, if examined, be found rather to confirm than difprove the above remark. The language of a people on thefe points may, perhaps, ferve in fome meafure as a key to their moral fentiments. But fuch fpeculative difquifitions are foreign to the purpofe of the prefent work. 


\section{Of buman [D I S P O S I T I O N S] in general.}

ftate of tolerable civilization, in fhort, in any nation in which fuch INTROD. rules as thefe can come to be confulted, the dictates of the moral fanction will fo far recede from a coincidence with thofe of utility (that is, of enlightened benevolence) that the difpofition indicated in this cafe can be otherwife than a good one upon the whole.

\section{XIX.}

An Indian receives an injury, real or imaginary, from an Indian of Example $\mathrm{I}$. another tribe. He revenges it upon the perfon of his antagonift with the moft excruciating torments : the cafe being, that cruelties inflicted on fuch an occafion, gain him reputation in his own tribe. The difpofition manifefted in fuch a cafe can never be deemed a good one, among a people ever fo few degrees advanced, in point of civilization, above the Indians.

\section{$\mathrm{XX}$.}

A nobleman (to come back to Europe) contracts a debt with a poor Example II. tradefman. The fame nobleman, prefently afterwards, contracts a debt, to the fame amount, to another nobleman, at play. $\mathrm{He}$ is unable to pay both : he pays the whole debt to the companion of his amufements, and no part of it to the tradefman. The difpofition manifefted in this cafe can fcarcely be termed otherwife than a bad one. It is certainly, however, not fo bad as if he had paid neither. The principle of love of reputation, or (as it is called in the cafe of this partial application of it) honour, is here oppofed to the worthier principle of benevolence, and gets the better of it. But it gets the better alfo of the felf-regarding principle of pecuniary intereft. The difpofition, therefore, which it indicates, although not fo good a one as that in which the principle of benevolence predominates, $;$ is better than one in which the principle of felf-intereft predominates. He would be the better for having more benevolence : but would he be the better for having no honour? This feems to admit of great difpute*.

\section{XXI.}

7. Where the tendency of the act is good, and the motive is the Cafe 7.Tenfemi-focial one of religion. In this cafe, the difpofition indicated by dency,good-

- See the cafe of Duels difcuffed in B. I. tit. [Homicide.] 
INTROD. it (confidered with refpect to the influence of it on the man's conduct ChAP.XI. towards others) is manifeftly a beneficent and meritorious one.

A baker diftributes bread gratis among the induftrious poor. It is not that he feels for their diftreffes : nor is it for the fake of gaining reputation among his neighbours. It is for the fake of gaining the favour of the Deity: to whom, he takes for granted, fuch conduct will be acceptable. The difpofition maniferted by fuch conduet is plainly what every man would call a good one.

XXII.

Cafe 8. Ten dency, badmotive, religion.

8. Where the tendency of the act is bad, and the motive is that of religion, as before. In this cafe the difpofition is dubious. It is good or bad, and more or lefs good or bad, in the firft place, as the tendency of the act is more or lefs mifclievous; in the next place, according as the religious tenets of the perfon in queftion approach more or leis to a coincidence with the dictates of utility.

\section{XXIII.}

The difpofition may be bad in this

It thould feem from hiftory, that even in nations in a tolerable ftate of civilization in other refpects, the dictates of religion have been cafe. found fo far to recede from a coincidence with thofe of utility; in other words, from thofe of enlightened benevolence; that the difpofition indicated in this cafe may even be a bad one upon the whole. This however is no objection to the inference which it affords of a good difpofition in thofe countries (fuch as perhaps are moft of the countries of Europe at prefent) in which its dictates refpecting the conduct of a. man towards other men approach very nearly to a coincidence with thofe of utility. The dictates of religion, in their application to the conduct of a man in what concerns himfelf alone, feem in moft European nations to favour a good deal of the afcetic principle: but the obedience to fuch miftaken diftates indicates not any fuch difpofition as is likely to break out into acts of pernicious tendency with refpect to others. Inftances in which the dictates of religion lead a man into acts which are pernicious in this latter view, feem at prefent to be but rare : unlefs it be acts of perfecution, or impolitic meafures on the part of government, where the law itfelf is either the principal actor or an accomplice 


\section{of buman [D I S P O S I T I O N S] in general.}

accomplice in the mifchief. Ravaillac, inftigated by no other motive than this, gave his country one of the moft fatal ftabs that a country ever received from a fingle hand: but happily the Ravaillacs are but rare. They have been more frequent, however, in France than in any other country during the fame period : and it is remarkable, that in every inftance it is this motive that has produced them. When they do appear, however, nobody, I fuppofe, but fuch as themfelves, will be for terming a difpofition, fuch as they manifeft, a good one. It feems hardly to be denied, but that they are juft fo much the worfe for their notions of religion; and that had they been left to the fole guidance of benevolence, and the love of reputation, without any religion at all, it would have been but fo much the better for mankind. One may fay nearly the fame thing, perhaps, of thofe perfons who, without any particular obligation, have taken an active part in the execution of laws made for the punifhment of thofe who have the misfortune to differ with the magiftrate in matters of religion, much more of the leginator himfelf, who has put it in their power. If Lewis XIV. had had no religion, France would not have loft 800,000 of its moft valuable fubjects. The fame thing may be faid of the authors of the wars called holy ones; whether waged againt perfons called Infidels, or perfons branded with the ftill more odious name of Heretics. In Denmark, not a great many years ago, a fect is faid to have arifen, who; by a ftrange perverfion of reafon, took it into their heads, that, by leading to repentance, murder, or any other horrid crime, might be made the road to heaven. It Mould all along, however, be obferved, that inftances of this latter kind were always rare: and that in almoft all the countries of Europe, inftances of the former kind, though once abundantly frequent, have for fome time ceafed. In certain countries, however, perfecution at home, or (what produces a degree of reftraint, which is one part of the mifchiefs of perfecution) I mean the difpofition to perfecute, whenfoever occafion happens, is not yet at an end : infomuch that if there is no actual perfecution, it is only becaufe there are no heretics; and if there are no heretics, it is only becaufe there are no thinkers*.

Vol. I.

* See B. I. tit. [Offences againt Religion.] 
crxxvïi

INTROD.

CHAP.XI.

Cafe 9. Ten-
dency, gooddency, good malevolence.

Example.

\section{Of buman [D F SP OS I T I O N S] in generd.}

\section{XXIV.}

9. Where the tendency of the act is good, and the motive (as before) is the dif-focial one of ill-will. In this cafe the motive feems not to afford any indication on either fide. It is no indication of a good difpofition; but neither is it any indication of a bad one.

You have detected a baker in felling thort weight: you profecute him for the cheat. It is not for the fake of gain that you engaged in the profecution; for there is nothing to be got by it : it is not from public fpirit: it is not for the fake of reputation; for there is no reputation to be got by it: it is not in the view of pleafing the Deity: it is merely on account of a quarrel you have with the man you profecute. From the tranfaction, as thus ftated, there does not feem to be any thing to be faid either in favour of your difpofition or againft it. The tendency of the act is good: but you would not have engaged in it, had it not been from a motive which there feems no particular reafon to conclude will ever prompt you to engage in an act of the fame kind again. Your motive is of that fort which may, with leaft impropriety, be termed a bad one : but the act is of that fort, which, were it engaged in ever fo often, could never have any evil tendency; nor indeed any other tendency than a good one. By the fuppofition, the motive it happened to be dictated by was that of ill-will: but the act itielf is of fuch a nature as to have wanted nothing but fufficient difcernment on your part in order to have been dictated by the moft enlarged benevolence. Now, from a man's having fuffered himfelf to be induced to gratify his refentment by means of an act of which the tendency is good, it by no means follows that he would be ready on another occafion, through the influence of the fame fort of motive, to engage in any act of which the tendency is a bad one. The motive that impelled you was a diffocial one: but what focial motive could there have been to reftrain you? None, but what might have been outweighed by a more enlarged motive of the fame kind. Now, becaufe the diffocial motive prevailed when it ftood alone, it by no means follows that it would prevail when it had a focial one to combat it. 


\section{of buman [D I S P O S I T I O N S] in general.}

10. Where the tendency of the act is bad, and the motive is the diffocial one of malevolence. In this cafe the difpofition it indicates is of courfe a mirchievous one.

The man who ftole the bread from the baker, as before, did it with no other view than merely to impoverifh and afflict him: accordingly, when he had got the bread, he did not eat, or fell it; but deftroyed it. That the difpofition, evidenced by fuch a tranfaction, is a bad one, is what every body muft perceive immediately.

\section{XXVI.}

Thus much with refpect to the circumftances from which the mif- Problemchievoufnefs or meritorioufnefs of a man's difpofition is to be inferred in the grofs: we come now to the meafure of that mifchievoufnefs or meritorioufnefs, as refulting from thofe circumftances. Now with meto meafure the depravity in a man's difpofition. ritorious acts and difpofitions we have no direct concern in the prefent work. All that penal law is concerned to do, is to meafure the depravity of the difpofition where the act is mifchievous. To this object, therefore, we thall here confine ourfelves.

XXVII.

It is evident, that the nature of a man's difpofition muft depend A man's difupon the nature of the motives he is apt to be influenced by : in other words, upon the degree of his fenfibility to the force of fuch and fuch motives. For his difpofition is, as it were, the fum of his intentions : the difpofition he is of during a certain period, the fum or refult of his intentions during that period. If, of the acts he has been intending to engage in during the fuppofed period, thofe which are apparently of a mifchievous tendency, bear a large proportion to thofe which appear to him to be of the contrary tendency, his difpofition will be of the mifchievous caft: if but a fmall proportion, of the innocent or upright.

\section{XXVIII}

Now intentions, like every thing elfe, are produced by the things -which that are their caufes: and the caufes of intentions are motives. If, on birth to mo: 
INTROD. any occafion, a man forms either a good or a bad intention, it muft CHAP. XI. be by the influence of fome motive.

\section{XXIX.}

A feducing When the act, which a motive prompts a man to engage in, is of a or corrupting mifchievous nature, it may, for diftinction's fake, be termed a feducing
motive, what-a tutelary or prefervatory or corrupting motive: in which cafe alfo any motive which, in oppofition to the former, acts in the character of a reftraining motive, motive. may be ftiled a tutclary, prefervatory, or preferving motive.

\section{XXX.}

Tutelarymo- Tutelary motives may again be diftinguifhed into ftanding or contives are either ftanding or ocftant, and occafional. By ftanding tutelary motives, I mean fuch as act cafional.

with more or lefs force in all, or at leaft in moft cafes, tending to reftrain a man from any mifchievous acts he may be prompted to engage in; and that with a force which depends upon the general nature of the act, rather than upon any accidental circumftance with which any individual act of that fort may happen to be accompanied. By occafional tutelary motives, I mean fuch motives as may chance to act in this direction or not, according to the nature of the act, and of the particular occafion on which the engaging in it is brought into contemplation.

\section{XXXI.}

Standing tu- Now it has been thewn, that there is no fort of motive by which a telary motives are,

I. Good-

will. man may not be prompted to engage in acts that are of a mifchievous nature; that is, which may not come to at in the capacity of a feducing motive. It has been fhewn, on the other hand, that there are fome motives which are remarkably lefs likely to operate in this way than others. It has alfo been fhewn, that the leaft likely of all is that of benevolence or good-will : the moft common tendency of which, it has been thewn, is to act in the character of a tutelary motive. It has alfo been thewn, that even when by accident it acts in one way in the character of a feducing motive, ftill in another way it acts in the oppofite character of a tutelary one. The motive of good-will, in as far as it refpects the interefts of one fet of perfons, may prompt a man to 
engage in acts which are productive of mifchief to another and more INTROD. extenfive fet: but this is only becaufe his good-will is imperfect and Crap. XI. confined : not taking into contemplation the interefts of all the perfons whofe interefts are at ftake. The fame motive, were the affection it iffued from more enlarged, would operate effectually, in the character of a conftraining motive, againft that very act to which, by the fuppofition, it gives birth. This fame fort of motive may therefore, without any real contradiction or deviation from truth, be ranked in the number of ftanding tutelary motives, notwithftanding the occafions in which it may act at the fame time in the character of a feducing one.

\section{XXXII.}

The fame obfervation, nearly, may be applied to the femi-focial 2. The love motive of love of reputation. The force of this, like that of the tiom. former, is liable to be divided againft itfelf. As in the cafe of goodwill, the interefts of fome of the perfons, who may be the objects of that fentiment, are liable to be at variance with thofe of others: fo in the cafe of love of reputation, the fentiments of fome of the perfons, whofe good opinion is defired, may be at variance with the fentiments of other perfons of that number. Now in the cafe of an act, which is really of a mifchievous nature, it can fcarcely happen that there fhall be no perfons whatever who will look upon it with an eye of difapprobation. It can fcarcely ever happen, therefore, that an act really mifchievous thall not have fome part at leaft, if not the whole, of the force of this motive to oppofe it; nor, therefore, that this motive fhould not act with fome degree of force in the character of a tutelary: motive. This, therefore, may be fet down as another article in the catalogue of ftanding tutelary motives.

\section{XXXIII.}

The fame obfervation may be applied to the defire of amity, though 3 . The defire not in altogether equal meafure. For, notwithftanding the mifchievouf- of amity. nefs of an act, it may happen, without much difficulty, that all the perfons for whofe amity a man entertains any particular prefent defire which is accompanied with expectation, may concur in regarding it with 
INTROD, an eye rather of approbation than the contrary. This is but too apt Crap. XI. to be the cafe among fuch fraternities as thofe of thieves, fmugglers, and many other denominations of offenders. This, however, is not conftantly, nor indeed moft commonly the cafe: infomuch, that the defire of amity may ftill be regarded, upon the whole, as a tutelary motive, were it only from the clofenefs of its connection with the love of reputation. And it may be ranked among ftanding tutelary motives, fince, where it does apply, the force with which its acts, depends not upon the oecafional circumftances of the act which it oppofes, but upon principles as general as thofe upon which depend the action of the other femi-focial motives.

\section{XXXIV.}

4. The mo- The motive of religion is not altogether in the fame cafe with the tive of re- three former. The force of $t$ it is not, like theirs, liable to be divided
ligion. againt itfelf. I mean in the civilized nations of modern times, among whom the notion of the unity of the Godhead is univerfal. In times of claffical antiquity it was otherwife. If a man got Venus on his fide, Pallas was on the other: if Eolus was for him, Neptune was againt him. Eneas, with all his piety, had but a partial intereft at the court of heaven. That matter ftands upon a different footing now-adays. In any given perfon, the force of religion, whatever it be, is now all of it on one fide. It may balance, indeed, on which fide it thall declare itfelf: and it may declare itfelf, as we have feen already in but too many inftances, on the wrong as well as on the right. It has been, at leaft till lately, perhaps is ftill, accuftomed fo much to declare itfelf on the wrong fide, and that in fuch material inftances, that on that account it feemed not proper to place it, in point of focial tendency, on a level altogether with the motive of benevolence. Where it does act, however, as it does in by far the greateft number of cafes, in oppofition to the ordinary feducing motives, it acts, like the motive of benevolence, in an uniform manner, not depending upon the particular circumftances that may attend the commiffion of the act; but tending to oppofe it, merely on account of its mifchievoufnefs; and therefore, with equal force, in whatfoever circumftances it may be 


\section{Of buman [DIS P OSITIONS] in gelleral.}

propofed to be committed. This, therefore, may alfo be addcd to the catalogue of ftanding tutelary motives.

\section{XXXV.}

As to the motives which may operate occafionally in the character of tutelary motives, thefe, it has been already intimated, are of various forts, and various degrees of ftrength in various offences: depending not only upon the nature of the offence, but upon the accidental circumftances in which the idea of engaging in it may come in contemplation. Nor is there any fort of motive which may not come to operate in this character; as may be eafily conceived. A thief, for inftance, may be prevented from engaging in a projected fcheme of houfe-breaking, by fitting too long over his bottle *, by a vifit from his doxy, by the occafion he may have to go elfewhere, in order to receive his dividend of a former booty $t$; and fo on.

\section{XXXVI.}

There are fome motives, however, which feem more apt to act in Motives that this character than others; efpecially as things are conftituted now, are particuthat the law has every where oppofed to the force of the principal fe- act in this ducing motives, artificial tutelary motives of its $\mathrm{cwn}$ creation. Of the character are, motives here meant it will be neceffary to take a general view. They feem eafe. 2. Selfto be reducible to two heads; viz. 1 . The love of eafe; a motive put into prefervation. action by the profpect of the trouble of the attempt; that is, the trouble which it may be neceffary to beftow, in overcoming the phyfical difficulties that may accompany it. 2. Self-prefervation, as oppofed to the dangers to which a man may be expofed in the profecution of it.

\section{XXXVII.}

Thefe dangers may be either, $\mathbf{x}$. Of a purely phyfical nature: or, 2. Dangers refulting from moral agency; in other words, from the conduct of any fuch perfons to whom the act, if known, may be expected to prove obnoxious. But moral agency fuppofes knowledge with refpect to the circumftances that are to have the effect of external motives in giving birth to it. Now the obtaining fuch knowledge, with refpect to the commiffion of any obnoxious act, on the part of any

- Love of the pleafures of the palate.

+ Pecuniary intereft.

\section{Dangers to} which felfprefervation is moft apt in this cafe to have refpect, are, I. Dangers purely phyfical. 2. Dangers depending on detection. 
INTROD. perfons who may be difpofed to make the agent fuffer for it, is called CHAP. XI. deteition; and the agent concerning whom fuch knowledge is obtained, is faid to be detected. The dangers, therefore, which may threaten an offender from this quarter, depend, whatever they may be, on the event of his detection; and may therefore be all of them comprifed under the article of the danger of detection.

\section{XXXVIII.}

Danger depending on detection may refult from, 1. Oppofition on the fpot: 2. Sublequent punithment.

The force of the two ftanding tutelary motives of love of reputation, and defire of amity, depends upon detection.

The danger depending upon detection may be divided again into two branches: 1. That which may refult from any oppofition that may be made to the enterprize by perfons on the fpot; that is, at the very time the enterprize is carrying on: 2. That which refpects the legal punifhment, or other fuffering, that may await at a diftance upon the iffue of the enterprize.

\section{XXXIX.}

It may be worth calling to mind on this occafion, that among the tutelary motives, which have been ftiled conftant ones, there are two of which the force depends (though not fo entirely as the force of the occafional ones which have been juft mentioned, yet in a great meafure) upon the circumftance of detektion. Thefe, it may be remembered, are, the love of reputation, and the defire of amity. In proportion, therefore, as the chance of being detected appears greater, thefe motives will apply with the greater force: with the lefs force, as it appears lefs. This is not the cafe with the two other ftanding tutelary motives, that of benevolence, and that of religion.

XL.

Strength of a temptation, what is meant by it.

We are now in a condition to determine, with fome degree of precifion, what is to be underftood by the ftrength of a temptation, and what indication it may give of the degree of mifchievoufnefs in a man's difpofition in the cafe of any offence. When a man is prompted to engage in any mifchievous act, we will fay, for fhortnefs, in an offence, the ftrength of the temptation depends upon the ratio between the force of the feducing motives on the one hand, and fuch of the occafional tutelary ones, as the circumftances of the cafe call forth into action, on the other. The temptation, then, may be faid to be ftrong, 
when the pleafure or advantage to be got from the crime is fuch as in the eyes of the offender muft appear great in comparifon of the trouble and danger that appear to him to accompany the enterprize: night or weak, when that pleafure or advantage is fuch as muft appear fmall in comparifon of fuch trouble and fuch danger. It is plain the ftrength of the temptation depends not upon the force of the impelling (that is of the feducing) motives altogether: for let the opportunity be more favourable, that is, let the trouble, or any branch of the danger, be made lefs than before, it will be acknowledged, that the temptation is made fo much the ftronger: and on the other hand, let the opportunity become lefs favourable, or, in other words, let the trouble, or any branch of the danger, be made greater than before, the temptation will be fo much the weaker.

Now, after taking account of fuch tutelary motives as have been ftiled occafional, the only tutelary motives that can remain are thofe which have been termed ftanding ones. But thofe which have beěn termed the ftanding tutelary motives, are the fame that we have been ftiling focial. It follows, therefore, that the ftrength of the temptation, in any cafe, after deducting the force of the focial motives, is as the fum of the forces of the feducing, to the fum of the forces of the occafional tutelary motives.

\section{XLI.}

It remains to be enquired, what indication concerning the mif- Indications chievoufnefs or depravity of a man's difpofition is afforded by the afforded by frength of the temptation, in the cafe where any offence happens to have circumftances been committed. It appears, then, that the weaker the temptation is, by the depravity which a man has been overcome, the more depraved and mifchievous it of an offenmews his difpofition to have been. For the goodnefs of his difpofi- tion. tion is meafured by the degree of his fenfibility to the action of the focial motives * : in other words, by the ftrength of the influence which thofe motives have over him: now, the lefs confiderable the force is by which their influence on him has been overcome, the more convincing is the proof that has been given of the weaknefs of that influence.

\section{- Supra, par. xxvii. xxviii.}

Vor. I. 
INTROD. Again, The degree of a man's fenfibility to the force of the focial Crap. XI. motives being given, it is plain that the force with which thofe motives tend to reftrain him from engaging in any mifchievous enterprife, will be as the apparent mifchievoufnefs of fuch enterprife, that is, as the degree of mifchief with which it appears to bim likely to be attended, In other words, the lefs mifchievous the offence appears to him to be, the lefs averfe he will be, as far as he is guided by focial confiderations, to engage in it; the more mifchievous, the more averfe. If then the nature of the offence is fuch as muft appear to him highly mifchievous, and yet he engages in it notwithftanding, it thews, that the degree of his fenfibility to the force of the focial motives is but night; and confequently that his difpofition is proportionably depraved. Moreover, the lefs the ftrength of the temptation was, the more pernicious and depraved does it thew his difpofition to have been. For the lefs the Atrength of the temptation was, the lefs was the force which the influence of thofe motives had to overcome: the clearer therefore is the proof that has been given of the weaknefs of that influence.

\section{XLII.}

Rules for meafuring the depravity of difpofition indicated by an offence.
From what has been faid, it feems, that, for judging of the indication that is afforded concerning the depravity of a man's difpofition by the ftrength of the temptation, compared with the mifchievoufnefs of the enterprife, the following rules may be laid down:

Rule $\mathrm{I}$. The ftrength of the temptation being given, the mifchievoufnefs of the difpofition manifefted by the enterprife, is as the apparent mifcbicucusnefs of the aEt: Thus, it would hiew a more depraved difpofition, to murder a man for a reward of a guinea, or falfely to charge him with a robbery for the fame reward, than to obtain the fame fum from him by fimple theft: the trouble he would have to take, and the rifque he would have to run, being fuppofed to ftand on the fame footing in the one cafe as in the other.

Rule 2. The apparent mifchievoufnefs of the alt being given, a man's difpofition is the more depraved, the fligbter the temptation is by which be bas been overcome. Thus, it thews a more depraved and dangerous difpofition, if a man kill another out of mere fport, as the Emperor of Morocco, Muley

Mahomet, 
Mahomet, is faid to have done great numbers, than out of revenge, as Sylla and Marius did thoufands, or in the view of felf-prefervation, as Auguftus killed many, or even for lucre, as the fame Emperor is faid to have killed fome. And the effects of fuch a depravity, on that part of the public which is apprifed of it, run in the fame proportion. From Augurtus; fome perfons only had to fear, under fome particular circumftances. From Muley Mahomet, every man had to fear at all times.

Rule 3. The apparent mifchievoufness of the act being given, the evidence wbich it affords of the depravity of a man's difpofition is the lefs conclufive, the fronger the temptation is by which he bas been overcome. Thus, if a poor man, who is ready to die with hunger, fteal a loaf of bread, it is a lefs explicit fign of depravity, than if a rich man were to commit a theft to the fame amount. It will be obferved, that in this rule all that is faid is, that the evidence of depravity is in this cafe the lefs conclufive: it is not faid that the depravity is pofitively the lefs. For in this cafe it is poffible, for any thing that appears to the contrary, that the theft might have been committed, even had the temptation been not fo ftrong. In this cafe, the alleviating circumftance is only a matter of prefumption; in the former, the aggravating circumftance is a matter of certainty.

Rule 4. Where the motive is of the diffocial kind, the apparent mifcbievoufnefs of the alt, and the ftrength of the temptation, being given, the depravity is as the degree of deliberation with which it is accompanied. For in every man, be his difpofition ever fo depraved, the focial motives are thofe which, wherever the felf-regarding ones ftand neuter, regulate and determine the general tenor of his life. If the difiocial motives are put in action, it is only in particular circumftances, and on particular occafions; the gentle but conftant force of the focial motives, being for a while fubdued. The general and fanding bias of every man's nature is, therefore, towards that fide to which the force of the focial motives would determine him to adhere. This being the cafe, the force of the focial motives tends continually to put an end to that of the diffocial ones; as, in natural bodies, the force of friction tends to put an end to that which is generated by impulfe. Time, then, 
INTROD. which wears away the force of the diffocial motives, adds to that of the Crap. XI. focial. The longer, therefore, a man continues, on a given occafion, under the deminion of the diffocial motives, the more convincing is the proof that has been given of his infenfibility to the force of the focial ones.

Thus, it hews a worfe difpofition, where a man lays a deliberate plan for beating his antagonift, and beats him accordingly, than if he were to beat him upon the fpot, in confequence of a fudden quarrel : and worfe again, if, after having had him a long while together in his power, he beats him at intervals, and at his leifure*.

\section{XLIII.}

Ufe of this. The depravity of difpofition, indicated by an act, is a material conchapter. fideration. in feveral refpects. Any mark of extraordinary depravity, by adding to the terror already infpired by the crime, and by holding up the offender as a perfon from whom there may be more mifchief to be apprehended in future, adds in that way to the demand for punifhment. By indicating a general want of fenfibility on the part of the offender, it may add in another way alfo to the demand for punifhment. The article of difpofition is of the more importance, inafmuch as, in meafuring out the quantum of punishment, the principle of fympathy and antipathy is apt to look at nothing elfe. A man who punifhes becaufe he hates, and only becaufe he hates, fuch a man, when he does not find any thing odious in the difpofition, is not for punining at all; and when he does, he is not for carrying the punifhment further than his. hatred carries him. Hence the averfion we find fo frequently expreffed againft the maxim, that the punifhment muft rife with the ftrength of the temptation; a maxim, the contrary of which, as we thall fee, would be as cruel to offenders themfelves, as it would be fubverfive of the purpores of punifhment.

- See B. I. tit. [Confinement.] 


\section{H A P. XIr.}

$\$$ r. Shapes in which the mifcbief of an act may bew itfelf.

\section{I.}

H ITHERTO we have been fpeaking of the various articles or objects on which the confequences or tendency of an act may depend: of the bare adt itfelf: of the circumftances it may have been, or may have been fuppofed to be, accompanied with: of the confcioufINTROD. CHAP. XII. nefs a man may have had with refpect to any fuch circumftances : of the intentions that may have preceded the act: of the motives that may have given birth to thofe intentions: and of the difpofition that may have been indicated by the connection between fuch intentions and fuch motives. We now come to fpeak of confequences or tendency: an article which forms the concluding link in all this chain of caufes. and effects, involving in it the materiality of the whole. Now, fuch: part of this tendency as is of a mifchievous nature, is all that we have any direct concern with; to that, therefore, we Thall here confine ourfelves.

II.

The tendency of an act is mifchievous when the confequences of it Mifchief of are mifchievous; that is to fay, either the certain confequences or the probable. The confequences, how many and whatfoever they may be, of an act, of which the tendency is mifchievous, may, fuch of ous confethem as are mifchievous, be conceived to conftitute one aggregate body, which may be termed the mirchief of the act.

III.

This mifchief may frequently be diftinguifhed, as it were, into two The mifchief fhares or parcels: the one containing what may be called the primary of an act, mifchief; the other, what may be called the fecondary. That mare fecondary. may be termed the primary, which is fuftained by an afignable individual, or a multitude of affignable individuals. That hare may be 
INTROD. termed the fecondary, which, taking its origin from the former, extends CHap. XII. itfelf either over the whole community, or over fome other multitude. of unaffignable individuals.

IV.

Primary - The primary mifchief of an act may again be diftinguifhed into two original, or branches: 1. The original: and, 2. The derivative. By the original branch, I mean that which alights upon and is confined to any perfon who is a fufferer in the firft inftance, and on his own account: the perfon, for inftance, who is beaten, robbed, or murdered. By the derivative branch, I mean any thare of mifchief which may befall any other affignable perfons in confequence of his being a fufferer, and no otherwife. Thefe perfons muft, of courfe, be perfons who in fome way or other are connected with him. Now the ways in which one perfon may be connected with another, have been already feen: they may be connected in the way of intereft (meaning felf-regarding intereft) or merely in the way of fympatby. And again, perfons connected with a given perfon, in the way of intereft, may be connected with him either by affording support to him, or by deriving it from him *.

$\mathrm{V}$.

The fecon- The fecondary mifchief, again, may frequently be feen to confift of Alarm: or, two other thares or parcels : the firft confifting of pain; the other of 2. Danger. danger. The pain which it produces is a pain of apprehenfion: a pain grounded on the apprehenfion of fuffering fuch mifchiefs or inconveniences, whatever they may be, as it is the nature of the primary mifchief to produce. It may be ftiled, in one word, the alarm. The danger is the cbonce, whatever it may be, which the multitude it concerns may, in confequence of the primary mifchief, ftand expofed to, of fuffering fuch mifchiefs or inconveniences. For danger is nothing but the chance of pain, or, what comes to the fame thing, of lofs of pleafure.

VI.

Example. An example may ferve to make this clear. A man attacks you on the road, and robs you. You fuffer a pain on the occafion of lofing

- See ch. vi. [Senfibility.] 
fo much money ${ }^{2}$ : you alfo fuffered a pain at the thoughts of the perfonal ill-treatment you apprehended he might give you, in cafe of your not happening to fatisfy his demands ${ }^{b}$. Thefe together conftitute the original branch of the primary mifchief, refulting from the act of robbery. A creditor of your's, who expected you to pay him with part of that money, and a fon of your's, who expected you to have given him another part, are in confequence difappointed. You are obliged to have recourfe to the bounty of your father, to make good part of the deficiency. Thefe mifchiefs together make up the derivative branch. The report of this robbery circulates from hand to hand, and fpreads itfelf in the neighbourhood. It finds its way into the news-papers, and is propagated over the whole country. Various people, on this occafion, call to mind the danger which they and their friends, as it appears from this example, ftand expofed to in travelling; efpecially fuch as may have occafion to travel the fame road. On this occafion they naturally feel a certain degree of pain: nighter or heavier, according to the degree of ill-treatment they may underftand you to have received; the frequency of the occafion each perfon may have to travel in that fame road, or its neighbourhood; the vicinity of each perfon to the fpot; his perfonal courage; the quantity of money he may have occafion to carry about with him; and a variety of other circumftances. This conftitutes the firt part of the fecondary mifchief, refulting from the act of robbery; viz. the alarm. But people of one defcription or other, not only are difpofed to conceive themfelves to incur a chance of being robbed, in confequence of the robbery committed upon you, but (as will be fhewn prefently) they do really incur fuch a chance. And it is this chance which conftitutes the remaining part of the fecondary mifchief of the act of robbery; viz. the danger.

VH.

The danger, whence it arifes $-a$ Let us fee what this chance amounts to; and whence it comes. How is it, for inftance, that one robbery can contribute to produce

a Viz. a pain of privation. See ch. v. [Pleafures and Pains.] xvii.

- Viz, a pain of apprebenfion, grounded on the profpect of organical pain, or whatpalt offence affords no direet motive to a future. ever other mifchiefs might have enfued from the ill treatment. Ib. $x x x$. 
INTroD. another? In the firft place, it is certain that it cannot create any diСнар. XII. rect motive. A motive muft be the profpect of fome pleafure, or other advantage, to be enjoyed in future: but the robbery in quettion is paft : nor would it furnifh any fuch profpect were it to come: for it is not one robbery that will furnifh pleafure to him who may be about to commit another robbery. The confideration that is to operate upon a man, as a motive or inducement to commit a robbery, muft be the idea of the pleafure he expects to derive from the fruits of that very robbery: but this pleafure exifts independently of any other robbery.

VIII.

But it fuggefts feafibility, and weakens the force of reItraining motives.

The means, then, by which one robbery tends, as it hould feem, to produce another robbery, are two. 1. By fuggefting to a perfon expofed to the temptation, the idea of committing fuch another robbery (accompanied, perhaps, with the belief of its facility.) In this cafe the influence it exerts applies itfelf, in the firft place, to the underftanding. 2. By weakening the force of the tutelary motives which tend to reftrain him from fuch an action, and thereby adding to the ftrength of the temptation*. In this cafe the inAluence applies itfelf to the will. Thefe forces are, I. The motive of benevolence, which acts as a branch of the phyfical fanction ${ }^{c}$. 2. The motive of felf-prefervation, as againft the punifhment that may ftand provided by the political fanction. 3. The fear of thame; a motive belonging to the moral fanction. 4. The fear of the divine difpleafure; a motive belonging to the religious fanction. On the firft and laft of thefe forces it has, perhaps, no influence worth infifting on: but it has on the other two.

IX.

viz. 1. Thore iffuing from the political fanction.

The way in which a paft robbery may weaken the force with which the political fanction tends to prevent a future robbery, may be thus conceived. The way in which this fanction tends to prevent a robbery,

- See ch. xi. [Difpofitions.] xl.

- To wit, in virtue of the pain it may give a man to be a witnefs to, or otherwife confcious of, the fufferings of a fellow-creature : efpecially when he is himfelf the caufe of them: in a word, the pain of fympathy. See ch. v. [Pleafures and Pains] xxvi. 


\section{Of the [CONSEQUENCES] of a mifchievous act.}

is by denouncing fome particular kind of punifhment againit any who thall be guilty of it : the real value of which punifhment will of courfe be diminithed by the real uncertainty: as alfo, if there be any difference, the apparent value by the apparent uncertainty. Now this uncertainty is proportionably encreafed by every inftance in which a man is known to commit the offence, without undergoing the punimment. This, of courfe, will be the cafe with every offence for a certain time; in fhort, until the punifhment allotted to it takes place. If punifhment takes place at laft, this branch of the mifchief of the offence is then at laft, but not till then, put a ftop to.

$\mathrm{X}$.

The way in which a paft robbery may weaken the force with which the moral fanction tends to prevent a future robbery, may be thus conceived. The way in which the moral fanction tends to prevent a robbery, is by holding forth the indignation of mankind as ready to fall upon him who thall be guilty of it. Now this indignation will be the more formidable, according to the number of thofe who join in it: it will be the lefs fo, the fewer they are who join in it. But there cannot be a ftronger way of thewing that a man does not join in whatever indignation may be entertained againft a practice, than the engaging in it himfelf. It thews not only that he himfelf feels no indignation againft it, but that it feems to him there is no fufficient reafon for apprehending what indignation may be felt againft it by others. Accordingly, where robberies are frequent, and unpunimed, robberies are committed without thame. It was thus amongft the Grecians formerly *. It is thus among the Arabs ftill.

\section{XI.}

In whichever way then a paft offence tends to pave the way for the It is faid to commiffion of a future offence, whether by fuggefting the idea of operate by committing it, or by adding to the ftrength of the temptation, in both of example. cafes it may be faid to operate by the force or infiuence of example.

- See Hom. Odyff. L. xix. 1. 395. ib. L. Iii. l. 71. Plato de Rep. L. i. p. 576. edit. Ficin. Thucyd. L. i., and fee B. I. tit. [Offences againft external fecurity.]

Vor. I.

XII. The 
CHAp. XII. The two branches of the fecondary mifchief of an act, the alarm

The alarm and the danger, though connected are diftinguifhable. and the danger, muft not be confounded : though intimately connected, they are perfectly diftinct: either may fubfift without the other. The neighbourhood may be alarmed with the report of a robbery, when, in fact, no robbery, either has been committed or is in a way to be committed: a neighbourhood may be on the point of being difturbed by robberies, without knowing any thing of the matter. Accordingly; we thall foon perceive, that fome acts produce alarm without danger: others, danger without alarm.

\section{XIIT.}

Both may have refped to the fame perfon, or to others.

As well the danger as the alarm may again be divided, each of them, into two branches: the firft, confifting of fo much of the alarm: or danger as may be apt to refult from the future behaviour of the fame agent: the fecond, confifting of fo much as may be apt to refult: from the behaviour of other perfons: fuch others, to wit, as may come: to engage in acts. of the fame fort and tendency ${ }^{d}$.

\section{XIV.}

The primary confequences of an act may be mifchievous, and the fecondary beneficial.

The diftinction between the primary and the fecondary confequences? of an act, muft be carefully attended to. It is fo juft, that the latter may often be of a directly oppofite nature to the former. In fome cafes, where the primary confequences of the act are attended with $a$. mifchief, the fecondary confequences may be beneficial, and that to fuch a degree, as even greatly to outweigh the mifchief of the primary: This is the cafe, for inftance, with all acts of punifhment, when properly applied. Of thefe, the primary mifchief being never intended to fall but upon fuch perfons as may happen to have committed fome act which it is expedient to prevent, the fecondary mifchief, that is, the alarm and the danger, extends no farther than to fuch perfons as are under temptation to commit it: in which cafe, in as far as it tends to reftrain them from committing fuch acts, it is of a beneficial nature.

To the former of thefe branches is oppofed fo mueh of the force of any punithment, as is faid to operate in the way of reformation : to the latter, fo much as is faid 30. operate in the way of exampls. See ch. xiii. [Cafes unmeet] ii. note ${ }^{\text {a }}$.

$\mathrm{XV}$ : Thus 


\section{$\mathrm{XV}$.}

INTROD.

Thus much with regard to acts that produce pofitive pain, and that immediately. This cafe, by reafon of its fimplicity, feemed the fitteft to take the lead. But acts may produce mifchief in various other ways; which, together with thofe already fpecified, may all be comprized by the following abridged analyfis.

Mifchief may admit of a divifion in any one of three points of view. I. According to its own nature. 2. According to its caufe. 3. According to the perfon, or other party, who is the object of it ${ }^{e}$. With regard to its nature, it may be either fimple or complex *: when fimple, it may either be pofitive or negative: pofitive, confifting of actual pain: negative, confifting of the lofs of pleafure. Whether fimple or complex, and whether pofitive or negative, it may be either certain or contingent. When it is negative, it confifts of the lofs of fome benefit or advantage: this benefit may be material in both or either of two ways: 1. By affording actual pleafure: or, 2. By averting pain or danger, which is the chance of pain: that is, by affording fecurity. In as far, then, as the benefit which a mifchief tends to avert, is productive of fecurity, the tendency of fuch mifchief is to produce insecurity. 2. With regard to its caufe, mifchief may be produced either by one fingle action, or not without the concurrence of other actions: if not without the concurrence of other actions, thefe others may be the actions either of the fame perfon, or of other perfons: in either cafe, they may be either acts of the fame kind as that in queftion, or of otber kinds. 3. Laftly, with regard to the party who is the object of the mifchief, or, in other words, who is in a way to be affected by it, fuch party may be either an afignable $\dagger$ individual, or affemblage of individuals, or elfe a multitude of unalfignable individuals. When the object

- There may be other points of view, according to which mifchief might be divided, befides thefe : but this does not prevent the divifion here given from being an exhauftive one. A line may be divided in any one of an infinity of ways, and yet without leaving in any one of thofe cafes any remainder. See ch. xvi. [Divifion] i. note.

- Ch, v. [Pleafures and Pains] i. + See ch. xvi. [Divifion] iv. note.

Analyfis of the different Thapes in which the mifchief of an ast may thew itfelf. 
INTROD. is an affignable individual, this individual may either be the perfon

CHAP. XII. bimfelf who is the author of the mifchief, or fome otber perfon. When the individuals, who are the objects of it, are an unaffignable multitude, this multitude may be either the whole political community or ftate, or fome fubordinate divifion of it. Now when the object of the milchief is the author himfelf, it may be ftiled felf-regarding: when any other party is the object, extra-regarding: when fuch other party is an individual, it may be ftiled private: when a fubordinate branch of the community, femi-public: when the whole community, public. Here, for the prefent, we muft ftop. To purfue the fubject through its inferior diftinctions, will be the bufinefs of the chapter which exhibits the divifion of offences *.

-applied to the preceding cafes.
- to examples of other cafes where the mifchief is lefs confpicuous.

Example I. An act of felf-intoxication.
The cafes which have been already illuftrated, are thofe in which the primary mifchief is not neceffarily otherwife than a fimple one, and that pofitive: prefent, and therefore certain: producible by a fingle action, without any neceffity of the concurrence of any other action, either on the part of the fame agent, or of others; and having for its object an affignable individual, or, by accident, an affemblage of affignable individuals : extra-regarding therefore, and private. This primary mifchief is accompanied by a fecondary: the firft branch of which is fometimes contingent and fometimes certain, the other never otherwife than contingent: both extra-regarding and femi-public: In other refpects, pretty much upon a par with the primary mifchief: except that the firft branch, viz. the alarm, though inferior in magnitude to the primary, is, in point of extent, and therefore, upon the whole, in point of magnitude, much fuperior.

\section{XVI.}

Two inftances more will be fufficient to illuftrate the moft material of the modifications above exhibited.

A man drinks a vertain quantity of liquor, and intoxicates himfelf. The intoxication in this particular inftance does him no fort of harm: or, what comes to the fame thing, none that is perceptible. But it is probable, and indeed next to certain, that a given number of acts of - Ch. xri. 
the fame kind would do him a very confiderable degree of harm: INTROD. more or lefs according to his conftitution and other circumftances: for this is no more than what experience manifefts every day. It is alfo certain, that one act of this fort, by one means or other, tends confiderably to encreafe the difpofition a man may be in to practife other acts of the fame fort: for this alfo is verified by experience. This, therefore, is one inftance where the mifchief producible by the act is contingent: in other words, in which the tendency of the act is no otherwife mifchievous than in virtue of its producing a chance of mifchief. This chance depends upon the concurrence of other acts of the fame kind; and thofe fuch as mult be practifed by the fame perfon. The object of the mifchief is that very perfon himfelf who is the author of it, and he only, unlefs by accident. The mifchief is therefore private and felf-regarding.

As to its fecondary mifchief, alarm, it produces none: it produces indeed a certain quantity of danger by the influence of example : but it is not often that this danger will amount to a quantity worth regarding.

XVII.

Again. A man omits paying his thare to a public tax. This we Example Ir. fee is an act of the negative kind *. Is this then to be placed upon the Non-paylift of mifchievous acts? Yes, certainly. Upon what grounds? Upon tax. the following. To defend the community againft its external as well as its internal adverfaries, are tafks, not to mention others of a lefs indifpenfible nature, which cannot be fulfilled but at a confiderable expence. But whence is the money for defraying this expence to come? It can be obtained in no other manner than by contributions to be collected from individuals; in a word, by taxes. The produce then of thefe taxes is to be looked upon as a kind of benefit which it is neceffary the governing part of the community hould receive for the ufe of the whole. This produce, before it can be applied to its deftination, requires that there fhould be certain perfons commiffioned to receive and to apply it. Now if thefe perfons, had they received it, would have ap-

- See ch. vii. [Akions] vïi. 
INTROD. plied it to it its proper deftination, it would have been a benefit: CHAP. XII. the not putting them in a way to receive it, is then a mifchief. But it is poffible, that if received, it might not have been applied to its proper deftination; or that the fervices, in confideration of which it was beftowed, might not have been performed. It is poffible, that the under-officer, who collected the produce of the tax, might not have paid it over to his principal: it is poffible that the principal might not have forwarded it on according to its farther deftination; to the judge, for inftance, who is to protect the community againft its clandeftine enemies from within, or the foldier, who is to protect it againft its open enemies from without: it is poffible that the judge, or the foldier, had they received it, would not however have been induced by it to fulfil their refpective duties: it is poffible, that the judge would not have fat for the punifhment of criminals, and the decifion of controverfies: it is poffible that the foldier would not have drawn his fword in the defence of the community. Thefe, together with an infinity of other intermediate acts, which for the fake of brevity I pafs over, form a connected chain of duties, the difcharge of which is neceffary to the prefervation of the community. They muft every one of them be difcharged, ere the benefit to which they are contributory can be produced. If they are all difcharged, in that cafe the benefit fubfifts, and any act, by tending to intercept that benefit, may produce a mifchief. But if any of them are not, the benefit fails: it fails of itfelf : it would not have fubfifted, although the act in queftion (the act of non-payment) had not been committed. The benefit is therefore contingent; and, accordingly, upon a certain fuppofition, the act which confifts in the averting of it is not a mifchievous one. But this fuppofition, in any tolerably-ordered government, will rarely indeed be verified. In the very worft-ordered government that exifts, the greateft part of the duties that are levied are paid over according to their deftination: and, with regard to any particular fum, that is attempted to be levied upon any particular perfon upon any particular occafion, it is therefore manifeft, that, unlefs it be certain that it will not be fo difpofed of, the ast of withholding it is a mifchievous one. 
The act of payment, when referable to any particular fum, efpecially INTROD. if it be a fmall one, might alfo have failed of proving beneficial on another ground: and, confequently, the act of non-payment, of proving mifchievous. It is poffible that the fame fervices, precifely, might have been rendered without the money as with it. If then, fpeaking of any fmall limited fum, fuch as the greateft which any one perfon is called upon to pay at a time, a man were to fay, that the nonpayment of it would be attended with mifchievous confequences; this would be far from certain : but what comes to the fame thing as if it were, it is perfectly certain when applied to the whole. It is certain, that if all of a fudden the payment of all taxes was to ceafe, there would no longer be any thing effectual done, either for the maintenance of juftice, or for the defence of the community againt its foreign adverfaries: that therefore the weak would prefently be oppreffed and injured in all manner of ways, by the ftrong at home; and both together overwhelmed by oppreffors from abroad. Upon the whole, therefore, it is manifeft, that in this cafe, though the mifchief is remote and contingent, though in its firt appearance it confifs of nothing more than the interception of a benefit, and though the individuals, in whore favour that benefit would have been reduced into the explicit form of pleafure or fecurity, are altogether unaffignable, yet the mifchievous tendency of the act is not on all thefe accounts the lefs indifputable. The mifchief, in point of intenfity and duration, is indeed unknown: it is uncertain: it is remote. But in point of extent it is immenfe; and in point of fecundity, pregnant to a degree that baffles calculation.

\section{XVIII.}

It may now be time to obferve, that it is only in the cafe where the mifchief is extra-regarding, and has an affignable perfon or perfons for its object, that fo much of the fecondary branch of it as confints in alarm can have place. When the individuals it affects are uncertain, when no aifignabie perfon is the and al together out of fight, no alarm can be produced: as there is nobody. whofe fufferings you can fee, there is nobody whofe fufferings you can be alarmed at. No alarm, for inftance, is produced by non-payment to a. tax. If at any diftant and uncertain period of time fuch offence 
INTROD. Should chance to be productive of any kind of alarm, it would appear CHAP. XIr. to proceed, as indeed immediately it would proceed, from a very different caufe. It might be immediately referable, for example, to the act of a legiflator, who hould deem it neceffary to lay on a new tax, in order to make up for the deficiency occafioned in the produce of the old one. Or it might be referable to the act of an enemy, who, under favour of a deficiency thus created in the fund allotted for defence, might invade the country, and exact from it much heavier contributions than thofe which had been thus withholden from the fovereign.

As to any alarm which fuch an offence might raife among the few who might chance to regard the matter with the eyes of ftatefmen, it is of too night and uncertain a nature to be worth taking into the account.

\section{$\S 2$. How intentionality, $\Xi^{3} c$. may influence the miscbief of an abt.}

\section{XIX.}

Secondary mifchief influenced by the ftate of the agent's mind.

We have feen the nature of the fecondary mifchief, which is apt to be reflected, as it were, from the primary, in the cafes where the individuals who are the objects of the mifchief are affignable. It is now time to examine into the circumftances upon which the production of fuch fecondary mifchief depends. Thefe circumftances are no others than the four articles which have formed the fubjects of the four laft preceding chapters; viz. I. The intentionality. 2. The confcioufnefs. 3. The motive. 4. The difpofition. It is to be obferved all along, that it is only the danger that is immediately governed by the real ftate of the mind in refpect to thofe articles: it is by the apparent ftate of it that the alarm is governed. It is governed by the real only in as far as the apparent happens, as in moft cafes it may be expected to do, to quadrate with the real. The different influences of the articles of intentionality and confcioufnefs may be reprefented in the feveral cafes following.

$\mathrm{XX}$.

Cafe 1. In. Cafe r. Where the act is fo compleatly unintentional, as to be altovoluntarinefs gether involuntary. In this cafe it is attended with no fecondary mifchief at all. 
A bricklayer is at work upon a houfe : a paffenger is walking in the ftreet below. A fellow-workman comes and gives the bricklayer a violent purh, in confequence of which he falls upon the paffenger, and hurts him. It is plain there is nothing in this event that can give other people, who may happen to be in the ftreet, the leaft reafon to apprehend any thing in future on the part of the man who fell, whatever there may be with regard to the man who purhed him.

\section{$\mathrm{XXI}$.}

Cafe 2. Where the act, though not unintentional, is unadvifed, infomuch that the mifchievous part of the confequences is unintentional, but the unadvifednefs is attended with beedlefnefs. In this cafe the act is lefnefs. attended with fome fmall degree of fecondary mifchief, in proportion to the degree of heedleffnefs.

A groom being on horfeback, and riding through a frequented ftreet, turns a corner at a full pace, and rides over a paffenger, who happens to be going by. It is plain, by this behaviour of the groom, fome degree of alarm may be produced, lefs or greater, according to the degree of heedleffnefs betrayed by him: according to the quicknefs of his pace, the fullnefs of the ftreet, and fo forth. He has done mirchief, it may be faid, by his careleffnefs, already : who knows but that on other occafions the like caufe may produce the like effect?

\section{XXII.}

Cafe 3. Where the act is mifadvifed with refpect to a circumftance, which, had it exifted, would fully have excluded or (what comes to the fame thing) outweighed the primary mifchief: and there is no rafhnefs in the cafe. In this cafe the act is attended with no fecondary mifchief nithout rafhat all.

It is needlefs to multiply examples any farther.

$$
\text { XXIII. }
$$

Cafe 4 . Where the act is mifadvifed with refpect to a circumitance which would have excluded or counterbalanced the primary mifchief in part, but not entirely : and ftill there is no rafhnefs. In this cafe the act is attended with fome degree of fecondary mifchief, in proportion to that compleat juftification,

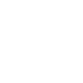
part of the primary which remains unexcluded or uncounterbalanced.

Vou. I. 


\section{clxii Of the [CONSEQUENCES] of a mifchievous att.}

INTROD. XXIV.

CHap. XII. Cafe 5 . Where the at is mifadvifed with refpect to a circumftance, Cafe 5. Mif- which, had it exifted, would have excluded or counterbalanced the primary fupporal, withrahnefs. mifchief entirely, or in part: and there is a degree of rafbne/s in the fuppofal. In this cafe, the act is alfo attended with a farther degree of fecondary mifchief, in proportion to the degree of rafhnefs.

Cafe 6. Conrequences compleatly intentional, and free from mif-fuppofal.

The nature of a motive takes not away the mifchief of the fecondary confequences.

\section{XXV.}

Cafe 6. Where the confequences are compleatly intentional, and there is no mif-fuppofal in the cafe. In this cafe the fecondary mifchief is at the higheft.

Thus much with regard to intentionality and confcioufnefs. We now come to confider in what manner the fecondary mifchief is affected by the nature of the motive.

Where an act is pernicious in its primary confequences, the fecondary mifchief is not obliterated by the goodness of the motive; though the motive be of the beft kind. For, notwithftanding the goodnefs of the motive, an act of which the primary confequences are pernicious, is produced by it in the inftance in queltion, by the fuppofition. It may, therefore, in other inftances : although this is not fo likely to happen from a good motive as from a bad one ${ }^{f}$.

In act of homicide, for inftance, is not rendered innocent, much lefs beneficial, merely by its proceeding from a principle of religion, of honour (that is, of love of reputation) or even of benevolence. When Ravaillac affaffinated Henry IV. it was from a principle of religion. But this did not fo much as abate from the mifchief of the act. It even rendered the act Atill more mifchievous, for a reafon that we thall fee prefently, than if it had originated from a principle of revenge. When the confpirators againft the late king of Portugal attempted to affafinate him, it is faid to have been from a principle of honour. But this, whether it abated or no, will certainly not be thought to have outweighed, the mifchief of the act. Had a fon of Ravaillac's, as in the cafe before fuppofed *, merely on the fcore of filial affection, and not in confequence of any participation in his crime, put him to death in order to refcue him from the feverer hands of juftice, the motive, although it fhould not be thought to afford any proof of a mifchievous difpofition, and thould, even in cafe of punifhment, have made fuch refcuer an object of pity, would hardly have made the act. of refcue a beneficial one.

$$
\text { *h. xi. [Difpofition] xy. }
$$

XXVII. An 
An aCt, which, tho' pernicious in its primary confequences, is rendered in other refpects beneficial upon the whole, by virtue of its fecondary confequences, is not changed back again, and rendered pernicious upon the whole by the badnefs of the motive: although the motive be of the worft kind?

\section{XXVIII.}

- But when not only the primary confequences of an act are perni- But it may cious, but, in other refpects, the fecondary likewife, the fecondary aggravatethe mifchief may be aggravated by the nature of the motive: fo much of that mifchief, to wit, as refpects the future behaviour of the fame mifichievourperfon.

XXIX. nefs, where they are mif

\section{XXIX.}

It is not from the wortt kind of motive, however, that the fecondary mifchief of an act receives its greateft aggravation.

\section{XXX.}

The aggravation which the fecondary mifchief of an act, in as far as it refpects the future behaviour of the fame perfon, receives from the nature of a motive in an individual cafe, is as the tendency of the motive to produce, on the part of the fame perfon, acts of the like bad tendency with that of the act in queftion.

But not the moft in the cafe of the worft motives.

It does the more, the ore confiderable the tendency of the motive to produce fuch acts.

B The profecution of offences, for inftance, proceeds molt commonly from one or other, or both together, of two motives, the one of which is of the felf-regarding, the other of the diffocial kind: viz. pecuniary interett, and ill-will : from pecuniary intereft, for inftance, whenever the obtaining pecuniary amends for damage fuffered is one end of the profecution. It is common enough indeed to hear men fpeak of profecusions undertaken from public fpirit; which is a branch, as we have feen * of the principle of benevolence. Far be it from me to deny but that fuch a principle may very frequently be an ingredient in the fum of motives, by which men are engaged in a proceeding of this nature. But whenever fuch a proceeding is engaged in from the fole influence of public fpirit, uncombined with the leaft tineture of felf-intereft, or ill-will, it muft be acknowledged to be a proceeding of the heroic kind. Now acts of heroifm are, in the very effence of them, but rare: for if they were common, they would not be acts of heroifm. But profecutions for crimes are very frequent, and yet, unlefs in very particular circumftances indeed, they are never otherwife than beneficial:

$$
\text { - See ch. X. [Motives.] xxv. }
$$


General efficacy of a fpecies of motive, how meafured. fluence on that perfon, as applied to the production of fuch effeets. \\ XXXII.}

The tendency of a fpecies of motive to give birth to acts of any kind, among perfons in.general, is as the frength, confancy, and extenfivenefs * of its influence, as applied to the production of fuch effects.

\section{XXXIII.}

A mifchievous act is more fo, when iffuing from a felf-regard.

ing than Now the motives, whereof the influence is at once moft powerful,
oft conftant, and moft extenfive, are the motives of phyfical defire, moft conftant, and mont extenfive, are the motives of phyfical defire,
the love of wealth, the love of eafe, the love of life, and the fear of pain : all of them felf-regarding motives. The motive of difpleafure, when fram a whatever it may be in point of ftrength and extenfivenefs, is not near fo conftant in its influence (the cafe of mere antipathy excepted) as any of the other three. A pernicious act, therefore, when committed through vengeance, or otherwife through difpleafure, is not near fo mifchievous as the fame pernicious act, when committed by force of any one of thofe other motives ${ }^{\text {s. }}$

\section{- Ch. iv. [Value.]}

${ }^{b}$ It is for this reafon that a threat, of other perfonal outrage, when committed on a franger, in purfuance of a fcheme of robbery, is productive of more mifchief in fociety, and accordingly is, perhaps, every where more feverely punifhed, than an outrage of the fame kind offered to an acquaintance, in profecution of a fcheme of vengeance. No man is always in a rage. But, at all times, every man, more or lefs, loves money. Accordingly, although a man by his quarrelfomenefs thould for once have been engaged in a bad action, he may neverthelefs remain a long while, or even his whole life-time. without engaging in another bad action of the fame kind: for he may very well remain his whole life-time without engaging in fo violent, a quarrel : nor at any rate will he quarrel with more than one, or a few people at a time. But if a man, by his love of money, has once been engaged in a bad action, fuch as a fcheme of robbery, he may. at any time, by the influence of the fame motive, be engaged in acts of the fame degree of enormity. For take men throughout, if a man loves money to a certain degree to-day, it is probable that he will love it, at lealt in equal degree, to-morrow. And if a man is difpofed to acquire it in that way, he will find inducement to rob, wherefoever and whenfoever there are people to be robbed. 
As to the motive of religion, whatever it may fometimes prove to be in point of ftrength and conftancy, it is not in point of extent fo univerfal, efpecially in its application to acts of a mifchievous nature, as any of the three preceding motives. It may, however, be as univerfal in a particular ftate, or in a particular diftrict of a particular ftate. It is liable indeed to be very irregular in its operations. It is apt, however, to be frequently as powerful as the motive of vengeance, or indeed any other motive whatfoever. It will fometimes even be more powerful than any other motive. It is at any rate much more conftant i. A pernicious act, therefore, when committed through the motive of religion, is more mifchievous than when committed through the motive of ill-will.

\section{XXXV.}

Laftly, The fecondary mifchief, to wit, fo much of it as hath refpect to the future behaviour of the fame perfon, is aggravated or leffened by the apparent depravity or beneficence of his difpofition: and that in the proportion of fuch apparent depravity or beneficence.

The confequences we have hitherto been fpeaking of, are the natural confequences, of which the act, and the other articles we have been confidering, are the caufes : confequences that refult from the behaviHow the fecondary mirchief is influenced by difpofition. our of the individual, who is the offending agent, without the interference of political authority. We now come to fpeak of punifbment: which, in the fenfe in which it is here confidered, is an artificial confequence, annexed by political authority to an offenfive act; in one inftance ; in the view of putting a ftop to the production of events fimilar to the obnoxious part of its natural confequences, in other inftances.

'If a man happen to take it into his head to affaflinate with his own hands, or with the fword of juftice, thofe whom he calls heretics, that is, people who think, or perhaps only fpeak, differently upon a fubject which neither party underftands, he will be as much inclined to do this at one time as at another. Fanaticifm never fleeps: it is never glutted : it is never ftopped by philanthropy; for it makes a merit of trampling on philanthropy: it is never ftopped by confcience; for it has preffed confcience into its fervice. Avarice, luft, and vengeance, have piety, benevolence, honour; fanaticifm Es nothing to oppofe it. 


\section{H A P. XIII. \\ \$1. General view of cajes unmeet for punibment.}

I.

INTROD. THE general object which all laws have, or ought to have, in Chap. XIII. I common, is to augment the total happinefs of the community; The end of and, therefore, in the firt place, to exclude, as far as may be, every
law is, to zugment happiners. thing that tends to fubtract from that happinefs : in other words, to exclude mifchief.

II.

But punih- But all punifhment is mifchief: all punifhment in itfelf is evil. ment is an Upon the principle of utility, if it ought at all to be admitted, it
evil: ought only to be admitted in as far as it promifes to exclude fome greater evil :.

III. It

What eoncerns the end, and feveral other topics, relative to punifhment, dir miffed to another work.

What follows, relative to the fubject of punifhment, ought regularly to be preceded by a diftinet chapter on the ends of punifhment. But having little to fay on that particular branch of the fubject, which has not been faid before, it feemed better, in a work, which will at any rate be but too voluminous, to omit this title, referving it for another, hereafter to be publifhed, intituled The Theory of punifment. To the fame work I muft refer the analyfis of the feveral poffible modes of punifhment, a particular and minute examination of the nature of each, and of its advantages and difadvantages, and various other difquifitions, which did not feem abfolutely neceffary to be inferted here. A very few words, however, concerning the ends of punifhment, can fcarcely be difpenfed with.

Concife view of the ends of

The immediate principal end of punifhment is to controul action. This action is punifhment. either that of the offender, or of others : that of the offender it controuls by its influence, either on his will, in which cafe it is faid to operate in the way of reformation; or on his phyfical power, in which cafe it is faid to operate by difablement.: that of others it can influence no otherwife than by its influence over their. wills; in which cafe it is faid to operate in the way of example. A kind of collateral end, which it has a natural tendency to anfwer, is that of affording a pleafure or fatisfaction to the party injured, where there is one, and, in general, to parties whofe ill-will, whether on a self-regarding account, or on the account of fympathy or antipathy, has been excited 
III.

It is plain, therefore, that in the following cafes punifhment ought not to be inflicted.

\section{CHAP. XIIT.}

Therefore

oughe not to

I. Where it is groundless; where there is no mifchief for it to pre- be admitted; vent; the act not being mifchievous upon the whole.

2. Where it muft be inefficacious : where it cannot act fo as to pre- 2. Inefficacivent the mifchief.

3. Where it is unprofitable, or too expenfive; where the mifchief it would produce would be greater than what it prevented.

4. Where it is needless: where the mifchief may be prevented, or 4. Or needceafe of itfelf, without it: that is, at a cheaper rate.

\section{\$. 2. Cafes in wbich punifbment is groundless.}

Thefe are,

IV.

I. Where there has never been any mifchief: where no mifchief has 1 . Where been produced to any body by the act in queftion. Of this number are thofe in which the act was fuch as might, on fome occafions, be mifchievous or difagreeable, but the perfon whofe intereft it concerns gave his there has any mifchief: as in the cafe confent to the performance of it $\dagger$. This confent, provided it be free, of confent. and fairly obtained + ; is the beft proof that can be produced, that, to the perfon who gives it, no mifchief, at leaft no immediate mifchief, upon

by the offence. This purpore, as far as it can be anfwered gratis, is a beneficial one. But no punifhment ought to be allotted merely to this purpofe, becaufe (fetting afide its effeets in the way of controul) no fuch pleafure is ever produced by puninment as can be equivalent to the pain. The punifhment, however, which is allotted to the other purpofe, ought, as far as it can be done without expence, to be accommodated to this. Satisfaction thus adminiftered. to a party injured, in the Mape of a diffocial pleafure *, may be ftiled a vindictive fatisfaction or compenfation: as a compenfation, adminiftered in the thàpe of a felf-regarding profit, or ftock of pleafure, may be ttiled a lucrative one. See B. I. titi vi. [Compenfation.] Example is the moft important end of all, in proportion as the number of the perfons under temptation to offend is to ans.

$$
\text { * See ch. x. [Motives.] }
$$

f.See B. I. tit. [Juftifications.] 


\section{clxviiii}

INTROD. Chap. XIII.

2. Where the mifchief was outweighed: as in precaution againft calamity, and the exercife of powers.

- - or will for a certainty, be cured by compenration.

1. Where the penal provifion comes too late: as in, 1. An ex-poffabzo law.

Hence the favour thewn to the offences of refponfible of-

fenders : fuch fimple mercantile frads.

\section{[C ASES UN MEE T] for punifbment.}

the whole, is done. For no man can be fo good a judge as the man himfelf, what it is gives him pleafure or difpleafure.

V.

2. Where the mifchief was outweighed: although a mifchief was produced by that act, yet the fame act was neceffary to the production of a benefit which was of greater value * than the mifchief. This may be the cafe with any thing that is done in the way of precaution againit inftant calamity, as alfo with any thing that is done in the exercife of the feveral forts of powers neceffary to be eftablinhed in every community, to wit, domeftic, judicial; military, and fupreme $\dagger$.

VI.

3. Where there is a certainty of an adequate compenfation: and that in all cafes where the offence can be committed. This fuppofes two things: I. That the offence is fuch as admits of an adequate compenfation: 2. That fuch a compenfation is fure to be forthcoming. Of thefe fuppofitions, the latter will be found to be a merely ideal one : a fuppofition that cannot, in the univerfality here given to it, be verified by fact. It cannot, therefore, in practice, be numbered amongft the grounds for abfolute impunity. It may, however, be admitted as a ground for an abatement of that punifhment, which other confiderations, ftanding by themfelves, would feem to dictate '.

\section{Cajes in wobich punifment muft be inefficacious.}

Thefe are,

VII.

I. Where the penal provifion is not eftabliffed until after the act is done. Such are the cafes, I. Of an ex-poft-facto law; where the legif-

\footnotetext{
- See fupra, ch. iv. [Value.]
}

+ See Book I. tit. [Juftifications:]

- This, for example, feems to have been one ground, at leaft, of the favour thewn by perhaps all fyitems of laws, to fuch offenders as ftand upon a footing of refponfibility: thewn, not direatly indeed to the perfons themfelves; but to fuch offences as none but refponfible perfons are likely to have the opportunity of engaging in. In particular, this feems to be the reafon why embezzlement, in certain cafes, has not commonly been punined upon the footing of theft: nor mercantile frauds upon that of common tharping 1 . 
lator himfelf appoints not a punimment till after the act is done. 2. Of a fentence beyond the law; where the judge, of his own authority, appoints a punifhment which the leginator had not appointed. - VIII.

INTROD.

Chap. XIII.

2. An ultralegal fen-

tence.

2. Where the penal provifion, though eftablinhed, is not conveyed to the notice of the perfon on whom it feems intended that it hould operate. Such is the cafe where the law has omitted to employ any of the expedients which are neceffary, to make fure that every perfon whatfoever, who is within the reach of the law, be apprized of all the cafes whatfoever, in which (being in the ftation of life he is in) he can be fubjected to the penalties of the law *.

IX.

3. Where the penal provifion, though it were conveyed to a man's notice, could produce no effect on him, with refpect to the preventing him from engaging in any act of the fort in queftion. Such is the cafe, $\mathrm{x}$. In extreme infancy; where a man has not yet attained that itate or difpofition of mind in which the profpect of evils fo diftant as thofe which are held forth by the law, has the effect of influencing his conduct. 2. In infanity; where the perfon, if he has attained to that difpofition, has fince been deprived of it through the influence of fome permanent though unfeen caufe. 3. In intoxication; where he has been deprived of it by the tranfient influence of a vifible caufe: fuch as the ufe of wine, or opium, or other drugs, that act in this manner on the nervous fyftem: which condition is indeed neither more nor lefs than a temporary infanity produced by an affignable caufe $c$.

Or is not made known: as in a law not fufficiently pro-: mulgated.

3. Where the will cannot be deterred from any act: as in, [a] Infancy.

[b] Infanity. [c] Intoxication.

X. 4 .

- See B. II. Appendix. tit. iii. [Promulgation.]

- Notwithltanding what is here faid, the cafes of infancy and intoxication (as we Shall fee hereafter) cannot be looked upon in practice as affording fufficient grounds for abfolute impunity. But this exception in point of practice is no objection to the pro. priety of the rule in point of theory. The ground of the exception is neither more nor lefs than the difficulty there is of afcertaining the matter of fact : viz. whether at the requifite point of time the party was actually in the ftate in queftion; that is, whether a given cafe comes really under the rule. Suppofe the matter of fact capable of being VOL. I. 
$\operatorname{clxx}$

INTROD.

Chap. XIII.

4. Or not from the individual act in queftion, as in,

[a] Uninten. tionality.

[b] Unconfcioufnefs.

[c] Mif-fuppofal.
[C A S S U N M E E T] for punifment.

$\mathrm{X}$.

4. Where the penal provifion (although, being conveyed to the party's notice, it might very well prevent his engaging in acts of the fort in queftion, provided he knew that it related to thofe acts) could not have this effect, with regard to the individual act he is about to engage in: to wit, becaufe he knows not that it is of the number of thofe to which the penal provifion relates. This may happen, I. In the cafe of unintentionality; where he intends not to engage, and thereby knows not that he is about to engage, in the act in which eventually he is about to engage +.2 . In the cafe of unconfcioufnefs; where, although he may know that he is about to engage in the alt itfelf, yet, from not knowing all the material circtmftances attending it, he knows not of the tendency it has to produce that mifchief, in contemplation of which it has been made penal in moft inftances. 3. In the cafe of miffuppofal; where, although he may know of the tendency the act has to produce that degree of mifchief, he fuppofes it, though miftakenly, to be attended with fome circumftance, or fet of circumftances, which, if it had been attended with, it would either not have been productive of that mifchief, or have been productive of fuch a greater degree of good, as has determined the legillator in fuch a cafe not to make it penal $f$.

\section{$\mathrm{XI}$.}

5. Where, though the penal claufe might exercife a full and pre-

5. Or is acted on by an oprior force : as by, vailing influence, were it to act alone, yet by the predominant influence of fome oppofite caufe upon the will, it muft neceffarily be

perfectly afcertained, without danger of miftake, the impropriety of punifhment would be as indubitable in thefe cafes as in any other*.

The reafon that is commonly affigned for the eftablining an exemption from punith-

ment in favour of infants, infane perfons, and perfons under intoxication, is either falfe in fact, or confufedily expreffed. The phrafe is, that the will of thefe perfons concurs not with the ad, that they have no vicious will; or, that they have not the free ufe of their will. But fuppofe all this to be true? What is it to the purpofe? Nothing : except in as far as it implies the reafon given in the text.

- See B. I. tit. iv. [Exemptions] and tit. vii. [Extenuations.]

+ See ch. viii. [Intentionality.]

\pm See ch. ix. [Confcioufnefs.]

ineffectual; 
ineffectual; becaufe the evil which he fees himfelf about to undergo, INTROD. in the cafe of his not engaging in the act, is fo great, that the evil de- Crap. XIII. nounced by the penal claufe, in cafe of his engaging in it, cannot appear greater. This may happen, I. In the cafe of phyfical danger; [a] Phyfical where the evil is fuch as appears likely to be brought about by the un- danger. aflifted powers of nature. 2. In the cafe of a tbreatened mifcbief; where it is fuch as appears likely to be brought about through the in- ened miftentional and confcious agency of man ${ }^{d}$.

XII.

6. Where (though the penal claufe may exert a full and prevailing 6.-or the influence over the will of the party) yet his pkyfical faculties (owing to bodily organs the predominant influence of fome phyfical caufe) are not in a condition cannot folto follow the determination of the will : infomuch that the act is abfo- mination: as lutely involuntary. Such is the cafe of phyfical compulfion or reftraint, Phyfical by whatever means brought about; where the man's hand, for inftance, compulfion is pufhed againft fome object which his will difpofes him not to touch; or tied down from touching fome object which his will difpofes him to touch.

\section{\$4. Cafés where punifsment is unprofitable.}

\section{Thefe are,}

\section{XIIY.}

1. Where, in the fort of cafe in quef-

r. Where, on the one hand, the nature of the offence, on the other care in querhand, that of the punifhment, are, in the ordinary fate of tbings, fuch, nifhment that when compared together, the evil of the latter will turn out to duce more be greater than that of the former.

evil than the

offence would.

d The influences of the moral and religious fanctions, or, in other words, of the motives of love of reputation and religion, are other caufes, the force of which may, upon particular occafions, come to be greater than that of any punifhment which the leginator is able, or at leaft which he will think proper, to apply. Thefe, therefore, it will be proper for in the ed in the fame in different times and places: the force of the foregoing influences is conftant and the fame, at all timcs and every where. Thefe, therefore, it can never be proper to look upon as fafe grounds for eftablifhing abfolute impunity: owing (as in the abovementioned cafes of infancy and intoxication) to the impracticability of afcertaining the matter of fad.

Z. 2.

XIV. Now 
clxxii

INTROD.

CHAP.XIII. Evil producible by a punifhment its four branchesviz. [a] $\mathrm{Re}=$ Araint.

[b] Appre. henfion.

[c] Sufferance.

[d].Derivative evils. the offence, being differentaccording to the nature of the offence, cannot be reprefented here.

Where in the individual cafe in queftion : by reafon of,

[a] The mullinquents.
[CASES UNMEET] for punifhment.

XIV.

Now the evil of the punimment divides itfelf into four branches, by which fo many different fets of perfons are affected. I. The evil of coercion or reftraint : or the pain which it gives a man not to be able to do the act, whatever it be, which by the apprehenfion of the punifhment he is deterred from doing. This is felt by thofe by whom the law is obferved. 2. The evil of apprebenfion: or the pain which a man, who has, or thinks he has, expofed himfelf to punifhment, feels at the thoughts of undergoing it. This is felt by him by whom the law has been broken, as alfo by him who fears he may be deemed to have broken it; both of whom feel themrelves in anger of its being executed upon them. 3. The evil of fufferance $\dagger$ : or the pain which a man feels, in virtue of the punifhment itfelf, from the time when he begins to undergo it. This is felt by thofe by whom the law is broken, and upon whom it comes actually to be executed. 4. The pain of fympathy, and the other derivative evils refulting to the perfons who are in conneizion with the feveral claffes of original fufferers juft mentioned *. Now of thefe four lots of evil, the firtt will be greater or lefs, according to the nature of the act from which the party is reftrained: the fecond and third, according to the nature of the punifhment which ftands annexed to that offence.

$\mathrm{XV}$.

On the other hand, as to the evil of the offence, this will alfo, of courfe, be greater or lefs, according to the nature of each offence. The proportion between the one evil and the other will therefore be different in the cale of each particular offence. The cafes, therefore, where punifhment is unprofitable on this ground, can by no other means be difcovered, than by an examination of each particular offence; which is what will be the bufinefs of the body of the work.

XVI.

2. Where, although in the ordinary ftate of things, the evil refulting from the punifhment is not greater than the benefit which is likely to refult from the force with which it operates, during the fame fpace of time, towards the excluding the evil of the offence, yet it may have been rendered fo by the infuence of fome occafional circumftances. In the number of thefe circumftances, may be, $\mathbf{1}$. The multitude of delinquents at a particular juncture; being fuch as would increafe, beyond

$$
+ \text { See ch, v. [Pleafures and Pains.] - See ch. xii. [Confequences] iv. }
$$


the ordinary meafure, the quantum of the fecond and third lots, INTROD. and thereby alfo of a part of the fourth lot, in the evil of the punifhment. 2. The extraordinary value of the fervices of fome one delinquent; in the cafe where the effect of the punifhment would be to deprive the community of the benefit of thofe fervices. 3. The difpleafure of the people; that is, of an indefinite number of the members of the fame community, in cafes where (owing to the influence of CHAP. XIIF [b] The value of a delinquent's fervice. [c] The difpleafure of the people. fome occafional incident) they happen to conceive, that the offence or the offender ought not to be punimed at all, or at leaft ought not to be punifhed in the way in queftion. 4. The difpleafure of foreign powers; that is, of the governing body, or a confiderable number of pleafure of members of fome foreign community or communities, with which the powers. community in queftion is connected.

\section{Cajes where punifoment is needlefs. \\ Thefe are, \\ XVII.}

1. Where the purpofe of putting an end to the practice may be attained as effectually at a cheaper rate: by inftruction, for inftance, as well as by terror: by informing the underftanding, as well as by exercifing an immediate influence on the will. This feems to be the cafe with refpect to all thofe offences which confint in the diffeminating pernicious principles in matters of duty; of whatever kind the duty be; whether political, or moral, or religious. And this, whether fuch principles be diffeminated under, or even witbout, a fincere perfuafion of their being beneficial. I fay, even witbout: for though in fuch a cafe it is not inftruction that can prevent the writer from endeavouring to inculcate his principles, yet it may the readers from adopting them: without which, his endeavouring to inculcate them will do no harm. In fuch a cafe, the fovereign will commonly have little need to take an active part : if it be the intereft of onc individual to inculcate principles that are pernicious, it will as furely be the intereft of otber individuals to expore them. But if the fovereign muft needs take a part in the controverfy, the pen is the proper weapon to combat error with, not the fword.

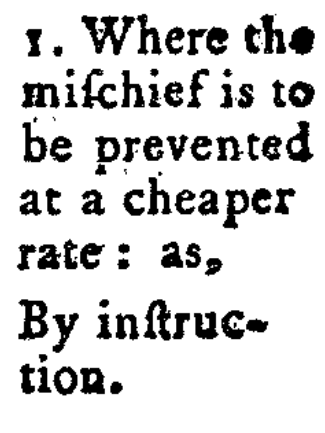
be prevented at a cheaper rate: 2s, By inftruction. 


\title{
clxxiv Of tbe [PROPORTION] between punibments and offences.
}

\author{
C H A P. XIV.
}

I.

INTROD. W ${ }^{\mathrm{E}}$ have feen that the general object of all laws is to prevent mifchief; that is to fay, when it is worth while; but that, Recapitula- where there are no other means of doing this than punifhment, there
tion. are four cafes in which it is not worth while.

II.

Four objects When it is worth while, there are four fubordinate defigns or of punifh-

ment. objects, which, in the courfe of his endeavours to compafs, as far as may be, that one general object, a leginator, whofe views are governed by the principle of utility, comes naturally to propofe to himfelf.

\section{III.}

It Objectto prevent all

1. His firf, mort extenfive, and moft eligible object, is to prevent, offences. in as far as it is poffible, and worth while, all forts of offences whatfoever ${ }^{2}:$ in other words, fo to manage, that no offence whatfoever may be committed.

IV.

2d Objectto prevent

2. But if a man muft needs commit an offence of fome kind or the worft. other, the next object is to induce him to commit an offence lefs mifchievous, ratber than one more mifchievous: in other words, to choofe always the leaft mifchievous, of two offences that will either of them fuit his purpofe.

\section{$\mathrm{V}$.}

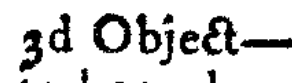

3. When a man has refolved upon a particular offence, the next ob. the mirchief. ject is to difpofe him to do no more mifchief than is necelfary to his purpofe : in other words, to do as little mifchief as is confiftent with the benefit he has in view.

2 By offences I mean, at prefent, acts which appear to him to have a tendency to produce mirchief.

VI. 4 . The 
VI.

4. The laft object is, whatever the mifchief be, which it is propofed to prevent, to prevent it at as cbeap a rate as pofible.

VII.

Subfervient to thefe four objects, or purpofes, muft be the rules or Rules of procanons by which the proportion of punimments ${ }^{\circ}$ to offences is to be portion begoverned.

VIII.

tween pu-

milhments

and offences.

Rule I.

I. The firft object, it has been feen, is to prevent, in as far as it is worth while, all forts of offences; therefore,

The value of the punifment muft not be lefs in any cafe than what is fufficient to outweigh that of the profit cof the offence *

If it be, the offence (unlefs fome other confiderations, independent of the punifhment, hould intervene and operate efficaciounly in the

- Beccaria, dei diletti, $\$ 6$. id. trad. par. Morellet, $\$ 23$.

- [Punifhments.] The fame rules (it is to be obferved) may be applied, with little The fame rules variation, to rewards as well as punithment: in mort, to motives in general, which, applicable to according as they are of the pleafurable or painful kind, are of the nature of revasard or neral. puni/mment : and, according as the act they are applied to produce is of the pofitive or negative kind, are ftiled impelling or reftraining. See ch. $x$. [Motives] $x$ liii.

c[Profit.] By the profit of an offence, is to be underftood, not merely the pecuniary profit may be of profit, but the pleafure or advantage, of whatever kind it be, which a man reaps, or ex. any other kind; pects to reap, from the gratification of the defire which prompted him to engage in the cuniary. offence *.

It is the profit (that is, the expectation of the profit) of the offence that confitutes Impropriety of the impelling motive, or, where there are feveral, the fum of the impelling motives, by the notion that which a man is prompted to engage in the offence. It is the punihment, that is, the ought not to inexpestation of the punifhment, that conflitutes the kefraining motive, which, either teafe with the by itfelf, or in conjunction with others, is to aet upon him in a contrary direction, fo as to induce him to abftain from engaging in the offence. Accidental circumftances apart, the ftrength of the temptation is as the force of the feducing, that is, of the impelling motive or motives. To fay then, as autiors of great merit and great name have faid, that the punihment ought not to increafe with the ftrength of the temptation, is as much as to fay in mechanics, that the moving force or momentum of the powver need not increafe in proportion to the momentum of the burthen.

- See ch. x. [Motives.] \$1. 


\section{clxxi Of the [PROPORTION] between punibments and offences.}

INTROD. character of tutelary motives ${ }^{*}$ ) will be fure to be committed notwithChap. XIV. ftanding ${ }^{d}$ : the whole lot of punihment will be thrown away: it will be altogether inefficacious $\ddagger$.

IX.

The propriety of taking the ftrength of the temptation for a ground of abatement, no objection to this rule.

The above rule has been often objected to, on account of its feeming harfhnefs : but this can only have happened for want of its being properly underftood. The ftrength of the temptation, cateris paribus, is as the profit of the offence : the quantum of the punimment mult rife with the profit of the offence: ceteris paribus, it mutt therefore rife with the ftrength of the temptation. This there is no difputing. True it is, that the ftronger the temptation, the lefs conclufive is the indication which the at of delinquency affords of the depravity of the offender's difpofition $\|$. So far then as the abfence of any aggravation, arifing from extraordinary depravity of difpofition, may operate, or at the usmoft, fo far as the prefence of a ground of extenuation, refulting

- See ch. xi. [Difpofitions] xxix.

- It is a well-known adage, though it is to be hoped not a true one, that every man has his price. It is commonly meant of a man's virtue. This faying, though in a very different fenfe, was ftrictly verified by fome of the Anglo-faxon laws : by which a fixed price'was fet, not upon a man's virtue indeed, but upon his life: that of the fovereign himfelf among the reft. For 200 millings you might have killed a peafant : for fix times as much, a nobleman : for fix-and-thirty times as much you might have killed the king t. A king in thofe days was worth exactly 7,200 thil. lings. If then the heir to the throne, for example, grew weary of waiting for it, he had a fecure and legal way of gratifying his impatience: he had but to kill the king with one hand, and pay himfelf with the other, and all was right. An earl Godwin, or a duke Streon, could have bought the lives of a whole dynafty. It is plain, that if ever a king in thofe days died in his bed, he mult have had fomething elfe, befides this law, to thank for it. This being the production of a remote and barbarous age, the abfurdity of it is prefently recognized: but, upon examination, it would be found, that the frefheft laws of the moft civilized nations are continually falling into the fanse error. This, in mort, is the cafe wherefoever the punimment is fixed, while the profit of delinquency is indefinite : or, to fpeak more precifely, where the punifhment is limited to fuch a mark, that the profit of delinquency may reach beyond it.

† Wilkins Leg. Anglo-fax, p. 7x, 72. See Hume. Vol. I. Append. I. p. 239.

1 See ch. xiii. [Cafes unmeet] \& 1 . \# See ch. xi. [Difpofitions] xlii. 


\section{of the [PROPORTION] between punifments and offences. clxxvii}

from the innocence or beneficence of the offender's difpofition, can INTROD: operate, the ftrength of the temptation may operate in abatement of Chap. XIV. the demand for punifhment. But it can never operate fo far as to indicate the propriety of making the punifhment ineffectual, which it is fure to be when brought below the level of the apparent profit of the offence.

The partial benevolence which thould prevail for the reduction of it below this level, would counteract as well thofe purpofes which fuch a motive would actually have in view, as thofe more extenfive purpofes which benevolence ought to have in view : it would be cruelty not only to the public, but to the very perfons in whofe behalf it pleads : in its effects, I mean, however oppofite in its intention. Cruelty to the public, that is cruelty to the innocent, by fuffering them, for want of an adequate protection, to lie expofed to the mifchief of the offence : cruelty even to the offender himfelf, by punihing him to no purpore, and without the chance of compaffing that beneficial end, by which alone the introduction of the evil of punimment is to be juftified.

$\mathrm{X}$.

Rule 2.

But whether a given offence thall be prevented in a given degree by Rule 2. Ven: a given quantity of punifhment, is never any thing better than a ture more chance; for the purchafing of which, whatever punifhment is em- great offence ployed, is fo much expended in advance. However, for the fake of than a fmall giving it the better chance of outweighing the profit of the offence,

The greater the mifcbief of the offence, the greater is the expence, which it may be worth wbile to be at, in the way of punifment ${ }^{c}$.

- For example, if it can ever be worth while to be at the expence of fo horrible Examplepunifhment as that of burning alive, it will be more fo in the view of preventing fuch Incendiarifm crime as that of murder or incendiarifm, than in the view of preventing the uttering of a piece of bad money. See B. I. tit. [Defraudment touching the Coin] and [Incendiarifm.]
Vol. 1.
A a
XI. Rule 


\section{clxxviii of the [PROPORTION] between punifinents and offences.}

Char. XIV.

Rule 3 .

Caufe the

leaft of two

offences to

be preferred.
INTROD.

$\mathrm{XI}$.

Rule 3 .

The next object is, to induce a man to choofe always the leaft mifchievous of two offences; therefore

Where two offences come in competition, the punifment for the greater offence muft be fufficient to induce a man to prefer the lefs*.

XII.

Rule 4.

Rule 4. When a man has refolved upon a particular offence, the next, object
unifh for each particle is, to induce him to do no more mifchief than what is neceffary for his of the mif- purpofe: therefore
chief.

The punifment jhould be adjufted in fucb manner to each particular of: fence, that for every part of the mischief there may be a motive to reftrain the offender from giving birth to it $\mathrm{s}$.

\section{XIII.}

Rule 5.

Rule 5. The laft object is, whatever mifchief is guarded againft, to guard Punith in no degree without fpecial reafon. . againft it at as cheap a rate as poffible : therefore

The punifbment ought in no cafe to be more than what is neceffary to bring it into conformity with the rules bere given.

* Efpr. des Loix, L. vi. c. 16.

Example, - In bows given, an f. If any one have any doubt of this, let him conceive the offence to be divided into as many feparate offences as there are diftinguibuable parcels of mifchief that refult from it. Let it confift, for example, in a man's giving you ten blows, or ftealing from you ten thillings. If then, for giving you ten blows, he is punithed no more than for giving you five, the giving you five of thefe ten blows is an offence for which there is no punifhment at all : which being underftood, as often as a man gives you five blows, he will be fure to give you Give more, fince he may have the pleafure of giving you thefe five for nothing. In like manner, if for ftealing from you ten inillings, he is punithed no more than for ftealing five, the ftealing of the remaining five of thofe ten fhillings is an offence for which there is no punifment at all. This rule is violated in almoft every page of every body of laws I have ever feen.

The profit, it is to be obferved, though frequently, is not conftantly, proportioned to the mifchief: for example, where a thief, along with the things he covets, fteals others which are of no ufe to him. This may happen through wantonnefs, indolence, pre. cipitation, \&c, \&c. 

degrees in which perfons under different circumftances are affected by the fame exciting caufe, a punifhment which is the fame in name will not always either really produce, or even fo much as appear to CHAP.XIV. others to produce, in two different perfons the fame degree of pain: therefore,

That the quantity actually inficted on each individual offender may correspond to the quantity intended for fimilar offenders in general, the feveral circumftances influencing fenfibility ought always to be taken into account *.

\section{$\mathrm{XV}$.}

Of the above rules of proportion, the four firft, we may perceive, ferve to mark out the limits on the fide of diminution; the limits below which a punifhment ought not to be diminifhed: the fifth, the limits on the fide of increafe; the limits above which it ought not to be increased. The five firft are calculated to ferve as guides to the leginator: the fixth is calculated, in fome meafure, indeed, for the fame purpofe; but principally for guiding the judge in his endeavours to conform, on both fides, to the intentions of the leginator.

\section{XVI.}

Let us look back a little. The firft rule, in order to render it more conveniently applicable to practice, may need perhaps to be a little more particularly unfolded. It is to be obferved, then, that for the fake of accuracy, it was neceffary, inftead of the word quantity, to make ufe of the lefs perfpicuous term value. For the word quantity will not properly include the circumftances either of certainty or proximity: circumftances which, in eftimating the value of a lot of

Into the account of the value of a punifhment, muft be taken its deficiency in point of certainty and proximity. pain or pleafure, mult always be taken into the account $t$. Now, on the one hand, a lot of punifhment is a lot of pain; on the other hand, the profit of an offence is a lot of pleafure, or what is equivalent to it. But the profit of the offence is commonly more certain than the punifhment, or, what comes to the fame thing, appears fo at leaft to the of-

* See ch. vi. [Senfibility.] t See ch. iv. [Value.]

A $a 2$ fender. 


\section{Ixxx Of the [PROPORTION] between punifments and offences.}

INTROD. fender. It is at any rate commonly more immediate. It follows, thereCHAP.XIV. fore, that, in order to maintain its fuperiority over the profit of the offence, the punifhment muft have its value made up in fome other way, in proportion to that whereby it falls thort in the two points of certainty and proximity. Now there is no other way in which it can receive any addition to its value, but by receiving an addition in point of magnitude. Wherever then the value of the punimment falls hort, either in point of certainty, or of proximity, of that of the profit of the offence, it muft receive a proportionable addition in point of magnitudes.

\section{XVII.}

Alfo, in to the account of the mifchief and profit of the offence, the mifchief and profit of of the fame kabit.

Yet farther. To make fure of giving the value of the punifhment. the fuperiority over that of the offence, it may be neceffary, in fome cafes, to take into the account the profit not only of the individual offence to which the punifhment is to be annexed, but alfo of fuch otber: offences of the fame fort as the offender is likely to have already. committed without detection. This random mode of calculation, fevere as it is, it will be impoffible to avoid having recourfe to, in certain cafes : in fuch, to wit, in which the profit is pecuniary, the chance of detection very fmall, and the obnoxious act of fuch a nature as indicates. a habit : for example, in the cafe of frauds againft the coin. If it be not recurred to, the practice of committing the affence will be fure to be, upon the balance of the account, a gainful practice. That being the cafe, the leginator will be abfolutely fure of not being able to fupprefs it, and the whole punifhment that is beftowed upon. it will be thrown away. In a word (to keep to the fame expreffions we fet out with) that whole quantity of punifhment will be inefficacious.

\section{XVIII.}

\section{Rule 7.}

Rule 7. Thefe things being confidered, the three following rules may be laid tainty mut down by way of fupplement and explanation to. Rule I.

It is for this reafon, for example, that fimple compenfation is never looked upon as fufficiers puninment for theft or robbery. 


\section{of the [PROPORTION] between punifsments and offences. elxxi}

To enable the value of the punifsment to outweigh that of the profit of the offence, it muft be encreased, in point of magnitude, in proportion as it falls Bort in point of certainty.

XIX.

INTROD. CHAP.XIV.

be made up in magnitude.

Rule 8.

Punifiment muft be furtber encreased in point of magnitude, in pro- Rule 8 . $\begin{array}{ll}\text { portion as it falls ßort in point of proximity: } & \text { So alfo want } \\ \text { of proximity. }\end{array}$ XX.

Rule 9,

Rule 9:

Where the act is conclufively indicative of a babit, fuch an encreafe muft For acts inbe given to the punifment as may enable it to outweigh the profit not only habit, punih. of the individual affence, but of fuch otber like offences, as are likely to bave as for the been committed with impunity by the Jame offender:

XXI.

There may be a few other circumftances or confiderations which The remainTher males are but of lefs imas the propriety of thefe is either not fo demonftrable, or not fo con- portance. ftant, or the application of them not fo determinate; as that of the foregoing, it may be doubted. whether they be worth putting on a level with the others.

XXIr.

R'ule I0.

Rule ro.

When a punifbment, which in point of quality is particularly well calcu- For the fake lated to anfwer its intention, cannot exift in lefs than a certain quantity, it of cruality, inmay fometimes be of ufe, for the fake of employing it, to ftretcb a little bes. quantity. yond that quantity wbich, on otber accounts, would be ftrictly neceffary.

\section{XXIII.}

Rule II.

Rule 11:

In particular, tbis may fometimes be the cafe, where the puniffment pron Particularly pofed. is of fucb a nature as to be particularly well calculated to anfwer the for a moral purpose of a moral leffon ${ }^{\mathrm{h}}$.

XXIV.

- A punifhment may be faid to be calculated to anfiver the purpofe of a moral lef- A punifiment fon, when, by reafor of the ignominy it ftamps upon the offence, it is calculated to applied by way infpire what, 


\section{claxxii of the [PROPORTION] between punifoments and affences.}

INTROD. Cinap. XIV.

\section{XXIV.}

Rule 12. Rule 2.

Attend tocir. cumitances which may render punifhment un profitable.

The tendency of the above confiderations is to dictate an augmentation in the punifhment: the following rule operates in the way of diminution. There are certain cafes (it has been feen ${ }^{*}$ ) in which, by the influence of accidental circumftances, punifhment may be rendered unprofitable in the whole: in the fame cafes it may chance to be rendered unprofitable as to a part only. Accordingly,

In adjufting the quantum of punifbment, the circumftances, by which all punifbment may be rendered unprofitable, ougbt to be attended to.

\section{XXV.}

\section{Rule 13.}

Rule 13. It is to be obferved, that the more various and minute any fet of ty's fake, provifions are, the greater the chance is that any given article in them frmall difpro- will not be born in mind : without which, no benefit can enfue from it. portions may
be neglected. Diftinctions, which are more complex than what the conceptions of thofe whofe conduct it is defigned to infuence can take in, will even be worfe than ufelefs. The whole fyftem will prefent a confufed appearance: and thus the effect, not only of the proportions eftablifhed by the articles in queftion, but of whatever is connected with them, will be deftroyed + . To draw a precife line of direction in fuch cafe feems impoffible. However, by way of memento, it may be of fome ufe to fubjoin the following rule.

infpire the public with fentiments of averfion towards thofe pernicious habits and dif pofitions with which the offence appears to be connected; and thereby to inculcate the oppofite beneficial habits and difpofitions.

Example.-In fimple corporal injuries.

It is this, for example, if any thing, that muft juftify the application of fo fevere a punifhment as the infamy of a public exhibition, hereinafter propofed, for him who lifts up his hand againft a woman, or againf his father. See B. I. tit. [Simp. corporal injuries.]

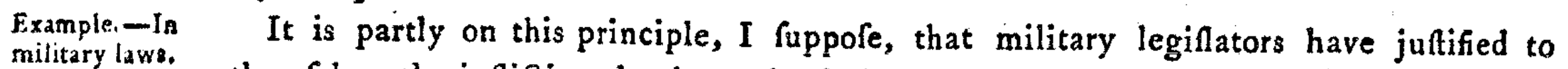
themfelves the inflicting death on the foldier who lifts up his hand againft his fuperior. officer.

- See ch. xiii. [Cafes unmeet. ] 4 . [Compolition.]

+ See B. II. tit. [Purpofes.] Append. tit. 
Among provifions defigned to perfect the proportion between punifbments INTROD. and offences, if any occur, wbich, by their own particular good effeets, would CHAp.XIV. not make up for the barm they would do by adding to the intricacy of the Code, they Bould be omitted .

\section{XXVI.}

It may be remembered, that the political fanotion, being that to Auxiliary which the fort of punifhment belongs, which in this chapter is all along force of the in view, is but one of four fanctions, which may all of in their thare towards producing the fame effects. It may be expected, fanction, not therefore, that in adjufting the quantity of political punifhment, al- here allowed lowance fhould be made for the affiftance it may meet with from thofe for-why. other controuling powers. True it is, that from each of thefe feveral fources a very powerful affiftance may fometines be derived. But the cafe is, that (fetting afide the moral fanction, in the cafe where the force of it is exprefsly adopted into and modified by the political ${ }^{*}$ ) the force of thofe other powers is never determinate enough to be depended upon. It can never be reduced, like political punifhment, into exact lots, nor meted out in number, quantity, and value. The leginator is therefore obliged to provide the full complement of punifhment, as if he were fure of not receiving any affitance whatever from any of thofe quarters. If he does, fo much the better: but leaft he fhould not, it is neceffary he fhould, at all events, make that provifion which depends upon himfelf.

\section{XXVII.}

It may be of ufe, in this place, to recapitulate the feveral circum- Recapitula. ftances, which, in eftablifhing the proportion betwixt punifhments and tion. offences, are to be attended to. Thefe feem to be as follows:

1 Notwithftanding this rule, my fear is, that in the enfuing model, I may be thought proportionality to have carried my endeavours at proportionality too far. Hitherto fcarce any atten - carried very fax tion has boen paid to it. Monkefquieu feems to have been almoft the frit who has had in work-why. the leaft idea of any fuch thing. In fuch a matter, therefore, excefs feemed more eligible than defect. The difficulty is to invent: that done, if any thing feems fuperfuous, it is eafy to retrench.

* See B. I. tit. [Punifhments.] 
claxxiv of the [PROPORTION] betweex puniffments and offences.

INTROD. I. On the part of the offence:

Chap. XIV.

1. The profit of the offence;

2. The mifchief of the offence;

3. The profit and mifchief of other greater or leffer offences, of different forts, which the offender may have to choore out of;

4. The profit and mifchief of other offences, of the fame fort, which the fame offender may probably have been guilty of already.

II. On the part of the punifment:

5. The magnitude of the punifhment: compofed of its intenfity and duration;

6. The deficiency of the punishment in point of certainty;

7. The deficiency of the punimment in point of proximity;

8. The quality of the punifhment ;

9. The accidental advantage in point of quality of a punifhment, not ftrictly needed in point of quantity;

10. The ufe of a punifhment of a particular quality, in the character of a moral leffon.

III. On the part of the offender:

II. The refponfibility of the clars of perfons in a way to offend;

12. The fenfibility of each particular offender;

13. The particular merits or ufeful qualities of any particular offender, in cafe of a punifhment which might deprive the community of the benefit of them;

14. The multitude of offenders on any particular occafion.

IV. On tbe part of the public, at any particular conjuncture:

15. The inclinations of the people, for or againft any quantity or mode of punifhment;

16. The inclinations of foreign powers.

V. On the part of the law: that is, of the public for a con: tinuance :

17. The neceffity of making fmall facrifices, in point of proportionality, for the fake of fimplicity.

XXVIII. 
XXVIII.

There are fome, perhaps, who, at firft fight, may look upon the nicety employed in the adjuftment of fuch rules, as fo much labour loft: for grofs ignorance, they will fay, never troubles itfelf about laws, and paffion does not calculate. But the evil of ignorance admits of cure* : and as to the propofition that pafion does not calcu- utility. late, this, like moft of thefe very general and oracular propofitions, is not true. When matters of fuch importance as pain and pleafure are at ftake, and thefe in the higheft degree (the only matters, in fhort, that can be of importance) who is there that does not calculate? Men calculate, fome with lefs exactnefs, indeed, fome with more: but all men calculate. I would not fay, that even a madman does not calculate $^{k}$. Paffion calculates, more or lefs, in every man: in different men, according to the warmth or coolnefs of their difpofitions : according to the firmnefs or irritability of their minds: according to the nature of the motives by which they are acted on. Happily, of all paffions, that is the moft given to calculation, from the exceffes of which, by reafon of its ftrength, conftancy, and univerfality, fociety has moft to apprehend $\dagger$ : I mean that which correfponds to the motive of pecuniary intereft: fo that thefe niceties, if fuch they are to be called, have the beft chance of being efficacious, where efficacy is of the moft importance.

* See Append. tit. [Promulgation.]

s There are few madmen but what are obferved to be afraid of the ftrait waiftcoat.

+ See ch. xii. [Confequences] xxxiii.

Vox. I.

B b

C H A P. 


\section{clxxxvi Of the [PR OPERTIES] to be given to a lot of punifament.}

INTROD.

CHAP. XV.

Properties are to be governed by proportion.

\section{H A P. XV.}

I.

$T$ has been thewn what the rules are, which ought to be obferved. in adjufting the proportion between the punifhment and the offence. The properties to be given to a lot of punifhment, in every inftance, will of courfe be fuch as it ftands in need of, in order to be capable of being applied, in conformity to thofe rules: the quality will be regulated by the quantity.

II.

Property I. The firt of thofe rules, we may remember, was, that the quantity of
Variability. Variability. punifhment muft not be lefs, in any cafe, than what is fufficient to outweigh the profit of the offence: fince, as often as it is lefs, the whole lot (unlefs by accident the deficiency thould be fupplied from fome of the other fanctions) is thrown away: it is inefficacicus. The fifth was, that the punifhment ought in no cafe to be more than what is required by the feveral other rules: fince, if it be, all that is above that quantity is needless. The fourth was, that the punifhment hould be adjufted in fuch manner to each individual offence, that every part of the mifchief of that offence may have a penalty (that is, a tutelary motive) to encounter it: otherwife, with refpect to fo much of the offence as has not a penalty to correfpond to it, it is as if there were no punifhment in the cafe. Now to none of thofe rules can a lot of punifhment be conformable, unlefs, for every variation in point of quantity, in the mifchief of the fpecies of offence to which it is annexed, fuch lot of punifhment admits of a correfpondent variation. To prove this, let the profit of the offence admit of a multitude of degrees. Suppofe it, then, at any one of thefe degrees: if the puninment be lefs than what is fuitable to that degree, it will be inefficacious; it will be fo much thrown away: if it be more, as far as the difference extends, it will be needle $/ s$; it will therefore be thrown away alfo in that cafe.

The firft property, therefore, that ought to be given to a lot of punifhment, 


\section{Of the [PROPERTIES] to be given to a lot of punifment. clxxxvii}

punifhment, is that of being variable in point of quantity, in confor- INTROD. mity to every variation which can take place in either the profit or Crap.XV. mifchief of the offence. This property might, perhaps, be termed, in a fingle word, variability.

\section{III.}

A fecond property, intimately connected with the former, may be ftiled equability. It will avail but little, that a mode of punifhment Property 2. (proper in all other refpects) has been eftablifhed by the leginator; and that capable of being fcrewed up or let down to any degree that can be required; if, after all, whatever degree of it be pitched upon, that fame degree fhall be liable, according to circumftances, to produce a very heavy degree of pain, or a very light one, or even none at all. In this cale, as in the former, if circumftances happen one way, there will be a great deal of pain produced which will be needlefs: if the other way, there will be no pain at all applied, or none that will be efficacious. A punifhment, when liable to this irregularity, may be ftiled an unequable one: when free from it, an equable one. The quantity of pain produced by the puninment will, it is true, depend in a confiderable degree upon circumftances diftinct from the nature of the punifhment itfelf : upon the condition which the offender is in, with refpect to the circumftances by which a man's fenfibility is 1 able to be influenced. But the influence of thefe very circumftances will in many cafes be reciprocally influenced by the nature of the punifhment : in other words, the pain which is produced by any mode of punifhment, will be the joint effect of the punifhment which is applied to him, and the circumftances in which he is expofed to it. Now there are fome punifhments, of which the effect may be liable to undergo a greater alteration by the influence of fuch foreign circumftances, than the effect of other punimments is liable to undergo. So far, then, as this is the cafe, equability or unequability may be regarded as properties belonging to the punifhment itfelf.

IV.

An example of a mode of punifhment which is apt to be Punillments unequable, is that of banifsment, when the locus a quo (or place the which areass party is banifhed from) is fome determinate place appointed by the thisis 


\section{clxxxviii Of the [PR OPERTIES] to be given to a lot of punifsment.}

INTROD. law, which perhaps the offender cares not whether he ever fee or no. CHAP.XV. This is alfo the cafe with pecuniary, or quafi-pecuniary punifhment, when it refpects fome particular fpecies of property, which the offender may have been poffeffed of, or not, as it may happen. All thefe punifhments may be fplit down into parcels, and meafured out with the utmoft nicety : being divifible by time, at leaft, if by nothing elfe. They are not, therefore, any of them defective in point of variability: and yet, in many cafes, this defect in puint of equability may make them as unfit for ufe as if they were ${ }^{2}$.

\section{V.}

Property 3. The third rule of proportion was, that where two offences come in furability to competition, the punifhment for the greater offence muft be fufficient other punifl- to induce a man to prefer the lefs. Now, to be fufficient for this pur-
ments. pofe, it muft be evidently and uniformly greater: greater, not in the eyes of fome men only, but of all men who are liable to be in a fituation to take their choice between the two offences; that is, in effect, of all mankind. In other words, the two punifhments mutt be perfectly commenfurable. Hence arifes a third property, which may be termed commenfurability: to wit, with reference to other punifhments [ $\left.{ }^{2}\right]$.

VI.

How two lots But punifhments of different kinds are in very few inftances uniformly ment may be greater one than another; efpecially when the loweft degrees of that rendered per- which is ordinarily the greater, are compared with the higheft degrees fectly com menfurable. of that which is ordinarily the lefs : in other words, punifhments of different kinds are in few inftances uniformly commenfurable. The only certain and univerfal means of making two lots of punifhment perfectly commenfurable, is by making the leffer an ingredient in the

a By the Englin law, there are feveral offences which are punifhed by a total forfeiture of moveables, not extending to immoveables. This is the cafe with ruicide, and with certain fpecies of theft and homicide. In fome cafes, this is the principal punifhment : in others, even the only one. The confequence is, that if a man's fortune happens to confift in moveables, he is ruined; if in immoveables, he fuffers nothing.

$\left.{ }^{2}\right]$ See View of the Hard-Labour Bill. Lond. 1778 . p. 100.

For the idea of this property, I muft acknowledge myfelf indebted to an anonymous letter in the St. James's Chronicle, of the $27^{\text {th }}$ of September 1777: the author of which is totally unknown to me. If any one hould be difpofed to think lightly of the infruction, on account of the channel by which it was fint communicated, let him tell me where $I$ can find an idea more ingenious or original. 


\section{Of the [PROPERTIES] to be given to a lot of punifbment. clxxxix}

compofition of the greater. This may be done in either of two ways. INTROD. I. By adding to the leffer punifhment another quantity of punifhment Cнат.XV. of the fame kind. 2. By adding to it another quantity of a different kind. The latter mode is not lefs certain than the former: for though one cannot always be abfolutely fure, that to the fame perfon a given punifhment will appear greater than another given punifhment; yet one may be always abfolutely fure, that any given punifhment, fo as it does but come. into contemplation, will appear greater than none at all.

VII.

Again: Punifhment cannot act any farther than in as far as the idea of it, and of its connection with the offence, is prefent in the mind. CharacterifThe idea of it, if not prefent, cannot act at all; and then the punifhment itfelf mult be inefficacious. Now, to be prefent, it muft be remembered, and to be remembered it mult have been learnt. But of all punifhments that can be imagined, there are none of which the connection with the offence is either fo eafily learnt, or fo efficaciouny remembered, as thofe of which the idea is already in part affociated with fome part of the idea of the offence: which is the cafe when the one and the other have fome circumftance that belongs to them in common. When this is the cafe with a punifhment and an offence, the punifhment is faid to bear an analogy to, or to be cbaracteriffic of, the offence*. Charasterifticalness is, therefore, a fourth property, which on this account ought to be given, whenever it can conveniently be given, to a lot of punifhment.

VIII.

It is obvious, that the effect of this contrivance will be the greater, as the analogy is the clofer. The analogy will be the clofer, the more material + that circumftance is, which is in common. Now the moft material circumftance that can belong to an offence and a punifhment in common, is the hurt or damage which they produce. The clofeft analogy, therefore, that can fubfift between an offence and the punifh- .

The mode of punifhment the mofteninently characterific, is that of re. taliation.

- See Montefg. ESp. des Loix. L. xii. ch. iv. He feems to have the property of characterifticalnefs in view: but that the idea he had of it was very indiftind, appears from the extravagant advantages he attributes to it. + See ch, vii. [Adions] iii. 
INTROD. ment annexed to it, is that which fubfifts between them when the hurt CHAP, XV. or damage they produce is of the fame nature: in other words, that which is conftituted by the circumitance of identity in point of damage $:$. Accordingly, the mode of punifhment, which of all others bears the clofert analogy to the offence, is that which in the proper and exact fenfe of the word is termed retaliation. Retaliation, therefore, in the few cafes in which it is practicable, and not too expenfive, will have one great advantage over every other mode of punihment.

IX.

Property 5. Again : It is the idea only of the punifhment (or, in other words, Exemplarity. the apparent puninment) that really acts upon the mind; the puninment itfelf (the real punifhment) acts not any farther than as giving rife to that idea. It is the apparent punimment, therefore, that does all the fervice, I mean in the way of example, which is the principal object *. It is the real punimment that does all the mifchief $t$. Now the ordinary and obvious way of increafing the magnitude of the apparent punilhment, is by increafing the magnitude of the real. The apparent magnitude, however, may to a certain degree be increafed by other lefs expenfive means: whenever, therefore, at the fame time that thefe lefs expenfive means would have anfwered that purpofe, an additional real punifhment is employed, this additional real punifhment is needlefs. As to thefe lefs expenfive means, they confift, I. In the choice of a particular mode of punifhment, a punifhment of a particular quality, independent of the quantity $\ddagger$. 2. In a particular fet of folemnities diftinet from the punifhment itfelf, and accompanying the execution of it $\|$.

$\mathrm{X}$.

The mot effectual way of rendering a punithment exemplary is by means of analogy.
A mode of punifhment, according as the appearance of it bears a greater proportion to the reality, may be faid to be the more exemplary. Now as to what concerns the choice of the puninment itfelf, there is not any means by which a given quantity of punifhment can be rendered more exemplary, than by choofing it of fuch a fort as

b Befides this, there are a variety of other ways in which the punifhment may bear an analogy to the offence. This will be feen by looking over the table of punimments.

- See ch. xiii. [Cafes unmeet] \$ 1, 2. note. +Ib. \$4. par. iii. $\$$ See B. I. tit. Punifhments. $\quad$ See B. II. tit. [Execution.] 
thall bear an analogy to the offence. Hence another reafon for render - INTROD. ing the punimment analogous to, or in other words characteriftic of, the offence.

$\mathrm{XI}$,

Punifhment, it is ftill to be remembered, is in itfelf an ex- Property 6 , pence: it is in itfelf an evil *. Accordingly the fifth rule of proportion is, not to produce more of it than what is demanded by the other rules. But this is the cafe as often as any particle of pain is produced, which contributes nothing to the effect propofed. Now if any mode of punifhment is more apt than another to produce any fuch fuperfluous and needlefs pain, it may be ttiled unfrugal; if lefs, it may be ftiled frugal. Frugality, therefore, is a fixth property to be withed for in a mode of punimment.

XII.

The perfection of frugality, in a mode of punifhment, is where not Frugality beonly no fuperfluous pain is produced on the part of the perfon longs in perpunifhed, but even that fame operation, by which he is fubjected to cuniary pupain, is made to anfwer the purpofe of producing pleafure on the ninment. part of fome other perfon. Underftand a profit or ftock of pleafure of the felf-regarding kind: for a pleafure of the diffocial kind is produced almoft of courfe, on the part of all perfons in whofe breafts the offence has excited the fentiment of ill-will. Now this is the cafe with pecuniary punihment, as alfo with fuch punifhments of the: quafi-pecuniary kind as confift in the fubftraction of fuch a fpecies of poffeffion as is transferable from one party to another. The pleafure, indeed, produced by fuch an operation, is not in general equal to the pain $t$ : it may, however, be fo in particular circumftances, as where he, from whom the thing is taken, is very rich, and he, to whom it is given, very poor: and, be it what it will, it is always fo much more. than can be produced by any other mode of punifhment:

\section{XIII.}

The properties of exemplarity and frugality feem to purfue the Exemplarity fame immediate end, though by different courfes. Both are occupied in what they

- Ch. xiii. [Cafes unmeet] par. ii. tlb. note. differ and. 


\section{cxcii Of the [PROPERTIES] to be given to a lot of punifsment.}

INTROD. in diminifing the ratio of the real fuffering to the apparent: but exCHA.XV. emplarity tends to increafe the apparent; frugality to reduce the real.

XIV.

Other pro- Thus much concerning the properties to be given to punithments perties of in- in general, to whatfoever offences they are to be applied. Thofe which
ferior importance. follow are of lefs importance, either as referring. only to certain offences in particular, or depending upon the influence of tranfitory and local circumftances.

In the firft place, the four diftinct ends into which the main and general end of punifhment is divifible *, may give rife to fo many diftinct properties, according as any particular mode of punifhment appears to be more particularly adapted to the compaffing of one or of another of thofe ends. To that of example, as being the principal one, a particular property has already been adapted. There remain the three inferior ones of reformation, difablement, and compenfation.

$$
\mathrm{XV} \text {. }
$$

Property 7. A feventh property, therefore, to be wifhed for in a mode of punifhSubferviency ment, is that of fubferviency to reformation, or reforming tendency. Now any
to reformation. punifhment is fubfervient to reformation in proportion to its quantity: fince the greater the punifhment a man has experienced, the ftronger is the tendency it has to create in him an averfion towards the offence which was the caufe of it: and that with refpect to all offences alike. But there are certain punifhments which, with regard to certain offences, have a particular tendency to produce that effect by reafon of their quality: and where this is the cafe, the punifhments in queftion, as applied to the offences in queftion, will pro tanto have the advantage over all others. This influence will depend upon the nature of the motive which is the caufe of the offence: the punifhment mort fubfervient to reformation will be the fort of punifhment that is beft calculated to invalidate the force of that motive.

- See ch, xiii. [Cafes unmeet] par. ii. note.

XVI. Thus, 
XVI.

INTROD.

Thus, in offences originating from the motive of ill-will *, that punifhment has the ftrongeft reforming tendency, which is beft calculated to weaken the force of the irafcible affections. And more particularly, in that fort of offence which confints in an obftinate refufal, on -applied to offences originating in the part of the offender, to do fomething which is lawfully required of him $t$, and in which the obftinacy is in great meafure kept up by his refentment againft thofe who have an intereft in forcing him to compliance, the moft efficacious punifhment feems to be that of confinement to fpare diet.

\section{XVII.}

Thus, alfo, in offences which owe their birth to the joint influence of -to offences indolence and pecuniary intereft, that punifhment feems to poffers the originating ftrongeft reforming tendency, which is beft calculated to weaken the force joined to peof the former of thofe difpofitions. And more particularly, in the cafes cuniary inof theft, embezzlement, and every fpecies of defraudment, the mode of punifhment beft adapted to this purpofe feems, in moft cafes, to be that of penal labour.

\section{XVIII.}

An eighth property to be given to a lot of punifhment in certain cafes, is that of efficacy with refpect to difablement, or, as it might be ftiled more briefly, difabling efficacy. This is a property which may Property 8. Efficacy with refpeet to be given in perfection to a lot of puninment; and that with much greater certainty than the property of fubferviency to reformation. The inconvenience is, that this property is apt, in general, to run counter to that of frugality: there being, in moft cafes, no certain way of difabling a man from doing mifchief, without, at the fame time, difabling him, in a great meafure, from doing good, either to himfelf or others. The mifchief therefore of the offence muft be fo great as to demand a very confiderable lot of punifhment, for the purpofe of example, before it can warrant the application of a puninment equal to that which is neceffary for the purpofe of difablement.

\section{- See ch. x. [Motives.]}

Vor. I.
+ See B. I. tit. [Offences againt Juflice.]

$$
\mathrm{C} c
$$

XIX. The 
cxciv of the [PROPERTIES] to be given to a lot of punifsment.

XIX.

INTROD.

CHAP.XV. The punifhment, of which the efficacy in this way is the greateft, -is mont is evidently that of death. In this cafe the efficacy of it is certain. confpicuous This accordingly is the punifhment peculiarly adapted to thofe cafes punifment. in which the name of the offender, fo long as he lives, may be fufficient to keep a whole nation in a flame. This will now and then: be the cale with competitors for the fovereignty, and leaders of factions in civil wars: though, when applied to offences of fo queftionable a nature, in which the queftion concerning criminality turns more upon fuccers than any thing elfe; an infliction of this fort may feem more: to favour of hoftility than punifhment. At the fame time this punifhment, it is evident, is in an eminent degree unfrugal; which forms. one among the many objections there are againft the ufe of it, in any but very extraordinary cafes $*$

\section{XX.}

Other pu-

In ordinary cafes the purpofe may be fufficiently anfwered by one ort be found. other of the various kinds of confinement and banifhment: of whichy; imprifonment is the moft ftrict and efficacious. For when an offence: is fo circumftanced that it cannot be committed but in a certain place, as is the cafe, for the moft part, with offences againft the perfon, all the law has to do, in order to difable the offender from committing it; is to prevent his being in that place. In any of the offences which. confift in the breach or the abufe of any kind of truft, the purpofe may be compaffed at a ftill cheaper rate, merely by forfeiture of the truft $:$ and in general, in any of thofe offences. which can only be committed: under favour of fome relation, in which the offender ftands with res. ference to any perfon, or fets of perfons, merely by forfeiture of that relation: that is, of the right of continuing to reap the advantages belonging to it. This is the cafe, for inftance, with any of thofe of: fences which confint in an abufe of the privileges of marriage, or of the liberty of carrying on any lucrative or other occupation:

- See B. I. tit. [Punifhments.]

XXXI. The. 
The ninth property is that of fubferviency to compenfation. This property of punifhment, if it be vindictive compenfation that is in view, will, with little variation, be in proportion to the quantity: if to compenzucrative, it is the peculiar and characteriftic property of pecuniary fation. punifhment.

\section{XXII.}

In the rear of all thefe properties may be introduced that of popularity; a very fleeting and indeterminate kind of property, which may Property 10. belong to a lot of punifhment one moment, and be loft by it the next. By popularity is meant the property of being acceptable, or rather not unacceptable, to the bulk of, the people, among whom it is propofed to be eftablifhed. In ftrictnefs of fpeech, it hould rather be called abfence of unpopularity: for it cannot be expected, in regard to fuch a matter as punifhment, that any fpecies or lot of it thould be pofitively acceptable and grateful to the people: it is fufficient, for the moft part, if they have no decided averfion to the thoughts of it. Now the property of characterifticalnefs, above noticed, feems to go as far towards conciliating the approbation of the people to a mode of punifhment, as any; infomuch that popularity may be regarded as a kind of $\mathrm{fe}$ condary quality, depending upon that of characterifticalnefs ${ }^{c}$. The ufe of inferting this property in the catalogue, is chiefly to make it ferve by way of memento to the legillator not to introduce, without a cogent neceffity, any mode or lot of punifhment, towards which he happens to perceive any violent averfion entertained by the body of the people.

\section{XXIII.}

The effects of unpopularity in a mode of punifhment are analogous Mifchiefs re. to thofe of unfrugality. The unneceffary pain which denominates

c The property of characterifticalnefs, therefore, is ufeful in a mode of punifhment in three different ways: 1 . It renders a mode of puninment, before infliction, more eafy to be borne in mind: 2. It enables it, efpecially after infliction, to make the ftronger impreffion, when it is there; that is, renders it the more exemplary: 3 . It tends to render it more acceptable to the people, that is, it renders it the more popular. 
INTROD, a punifhment unfrugal, is moft apt to be that which is produced ors Crap.XV. the part of the offender. A portion of fuperfluous pain is in like punithment -difcontent among the people, and weaknefs in the law. manner produced when the punifhment is unpopular: but in this cafe it is produced on the part of perfons altogether innocent, the people at large. This is already one mifchief; and another is, the weaknefs which it is apt to introduce into the law. When the people are fatiffied with the law, they voluntarily lend their affiftance in the execution: when they are diffatisfied, they will naturally withiold that affiftance; it is well if they do not take a pofitive part in raifing impediments. This contributes greatly to the uncertainty of the punilhment; by which, in the firft inftance, the frequency of the offence receives an increafe. In procefs of time that deficiency; as ufual, is. apt to draw on an encreafe in magnitude : an addition of a certain quantity which otherwife would be needlefs*.

\section{XXIV.}

This proper- This property, it is to be obferved, neceffarily fuppofes, on the ky fappores a part of the people, fome prejudice or other, which it is the bufinefs of
prejudice which the lee the leginator to endeavour to correct. For if the averfion to the ginator ought to sure. punifhment in queftion were grounded on the principle of utility, the punifhment would be fuch as, on other accounts, ought not to be employed: in which cafe its popularity or unpopularity would never be worth drawing into queftion. It is properly therefore a property not fo much of the punifhment as of the people : a difpofition to entertain an unreafonable dinike againft an object which merits their approbation. It is the fign alfo of another property, to wit; indolence or weaknefs, on the part of the leginator: in fuffering the people, for the want of fome inftruction, which ought to be and might be given. them, to quarrel with their own intereft. Be this as it may, fo long as any fuch diffatisfaction fubfifts, it behoves the leginator to have an eye to it, as much as if it were eyer fo well grounded. Every nation is liable to have its prejudices and its caprices, which it is the bufinefs of the leginator to look out for, to ftudy, and to cure $f$.

- See ch. xiii, [Cafes unmeet] \& v. + Ib. $\$$ iv. par. iv. 
Of the [PROPERTIES] to be given to a lot of punifment. $\mathrm{XXV}$.

The eleventh and laft of all the properties that feem to be requifite in a lot of punifhment, is that of remiffibility *. The general prefumption is, that when punifhment is applied, punifhment is needful : that it ought to be applied, and therefore cannot want to be remitted. But in very particular, and thofe always very deplorable cafes, it may by accident happen otherwife. It may happen that punifhment thall have been inflicted, where, according to the intention of the law itfelf, it ought not to have been inflieted: that is, where the fufferer is innocent of the offence. At the time of the fentence paffed he appeared guilty: but fince then, accident has brought his innocence to light. This being the cafe, fo much of the deftined punifhment as he has fuffered already, there is no help for.. The bufinefs is then to free him from as much as is yet to come. But is there any yet to come? There is very little chance of there being any, unlefs it be fo much as confifts of cbronical punifhment: fuch as imprifonment, banifhment, penal: labour, and the like. So much as.confifts in acute punifhment, to wit where the penal procefs itfelf is over prefently, however permanent the punifhment may, be in its. effects, may be confidered as irremiffible. This is the cafe, for example, with whipping, branding, mutilation, and capital punifhment. The moft perfectly: irremiffible of any is capital punifhment. For though other punifhments cannot, when they are over, be remitted, they, may be compenfated for: and although the unfortunate victim cannot be put into the fame condition, yet pofibly means may be found of putting, him into as good a condition, as he would have been in if he had never fuffered. This may in general be done very effectually where the punifhment has been no other than pecuniary.

There is another cafe in which the property of remiffibility may appear to be of ufe: this is, where, although the offender has. been juftly punithed, yet on account of fome good behaviour of his, difplayed at a time fubfequent to that of the commencement of the punilhment, it may feem expedient to remit a part of it. But this it can.

\footnotetext{
* See View of the Hard Labour Bill, p. 109.
}

fcarcely: cxcris

INTROD. CHAP. XV.

Property $11 \%$ Remiffibility. 


\section{excviii Of the [PROPERTIES] to be given to a lot of punifment.}

INTROD. fcarcely be, if the proportion of the punifhment is, in other refpects, Chap. XV. what it ought to be. The purpofe of example is the more important object, in comparifon of that of reformation*. It is not very likely, that lefs punifhment thould be required for the former purpofe than for the latter. For it muft be rather an extraordinary cafe, if a punifhment, which is fufficient to deter a man who has only thought of it for a few moments, Thould not be fufficient to deter a man who has been feeling it all the time. Whatever, then, is required for the purpofe of example, muft abide at all events: it is not any reformation on the part of the offender, that can warrant the remitting any part of it: if it could, a man would have nothing to do but to reform immediately, and fo free himfelf from the greateft part of that punifhment which was deemed neceffary. In order, then, to warrant the remitting of any part of a punifhment upon this ground, it muft firft be fuppofed that the punifhment at firft appointed was more than was neceffary for the purpofe of example, and confequently that a part of it was needless upon the whole. This, indeed, is apt enough to be the cafe, under the imperfect fyttems that are as yet on foot: and therefore, during the continuance of thofe fyftems, the property of remifibility may, on this fecond ground likewife, as well as on the former, be deemed a ufeful one. But this would not be the cafe in any new-conftracted fyftem, in which the rules of proportion above laid down thould be obferved. In fuch a fyftem, therefore, the utility of this property would reft folely on the former ground.

\section{XXVI.}

To obtain all Upon taking a furvey of the various poffible modes of punifhment, thefe proper- it will appear evidently, that there is not any one of them that poffeffes ties, punilhments mult be mixed. all the above properties in perfection. To do the beft that can be done in the way of punifhment, it will therefore be neceffary, upon moft occafions, to compound them, and make them into complex lots, each confifting of a number of different modes of punifhment put together : the nature and proportions of the conftituent parts of each lot being

\footnotetext{
- See ch. xiii. [Cafes unmeet] ii. note.
} 
different, according to the nature of the offence which it is defigned to INTROD. combat.

XXVII.

It may not be amifs to bring together, and exhibit in one view, the The foregoeleven properties above eftablifhed. They are as follows:

Two of them are concerned in eftablifhing a proper proportion be- ed. tween a fingle offence and its puninment; viz.
I. Variability:
2. Equability.

One, in eftablihing a proportion, between more offences than ones, and more punifhments than one; viz.

3. Commenfurability,

A fourth contributes to place the punifhment in that fituation in which alone it can be efficacious; and at the fame time to the beftowing on it the two farther properties of exemplarity and popularity; viz.

4. Characterifticalnefs.

Two others are concerned in excluding all ufelefs punifiment; the one indireetly, by heightening the efficacy of what is ufeful; the other in a direct way; viz.

5. Exemplarity.

6. Frugality.

Three others contribute feverally to the three inferior ends of punifhment ; viz.

7. Subferviency to reformation.

8. Efficacy in difabling.

9. Subferviency to compenfation.

Another property tends to exclude a collateral mifchief, which a particular mode of punifhment is liable accidentally to produce; viz.

10. Popularity.

The remaining property tends to palliate a mifchief, which an punifhment, as fuch, is liable accidentally to produce; viz.

I I. Remiffibility:

The properties of commenfurability, characterifticalnefs, exemplarity, 
INTROD. fubferviency to reformation, and efficacy in difabling, are more parChap.XV. ticularly calculated to augment the profit which is to be made by punifhment: frugality, fubferviency to compenfation, popularity, and remiffibility, to diminith the expence: variability and equability are alike fubfervient to both thofe purpofes.

\section{XXVIII.}

Connection

of this with

the enfuing

We now come to take a general furvey of the fyiftem of offences: chapter. that is, of fuch atts to which, on account of the mifchievous confequences they have a natural tendency to produce, and in the view of putting a ftop to thofe conlequences, it may be proper to annex a certain artificial confequence, confifting of punifhment, to be inflicted on the authors of fuch acts, according to the principles juft eftablifhed. 


\title{
C $\quad$ H A P. XVI.
}

\author{
$\$$ I. Clafjes of offences.
}

I.

$\mathbf{I}^{\mathrm{T}}$ $T$ is neceffary, at the outfet, to make a diftinction between fuch acts as are or may be, and fuch as ought to be offences. Any act may be an offence, which they whom the community are in the habit of obeying thall be pleafed to make one: that is, any act which they Shall be pleafed to prohibit or to punifh. But, upon the principle of utility, fuch acts alone ought to be made offences, as the good of the INTROD. Chaf. XVI. community requires thould be made fo.

II.

The good of the community cannot require, that any act fhould be made an offence, which is not liable, in fome way or other, to be detrimental to the community. For in the cafe of fuch an act, all punifhment is groundles".

III. But

$\overline{\text { Diftinction }}$ between what are offences and what ought to be.

No aft ought to be an offence but what is detrimental to the community.

2 This chapter is an attempt to put our ideas of offences into an exact method. The Method purparticular ufes of metbod are various : but the general one is, to enable men to under- fued in the folAtand the things that are the fubjects of it. To underftand a thing, is to be acquainted with its qualities or properties. Of thefe properties, fome are common to it with other things; the reft, peculiar. But the qualities which are peculiar to any one fort of thing are few indeed, in comparifon with thofe which are common to it with other things. To make it known in refpect of its difference, would, therefore, be doing little, unlefs it were made known alfo by its genus. To underftand it perfeetly, a man muft therefore be informed of the points in which it agrees, as well as of thofe in which it difagrees, with all other things. When a number of objests, compofing a logical whole, are to be confidered together, all of thefe poffefling with refpect to one another a certain congruency or agreement denoted by a certain name, there is but one way of giving a perfect knowledge of their nature; and that is, by diftributing them into a fyltem of parcels, each of them a part, either of fome other parcel, or, at any rate, of the common whole. This can only be done in the way of bipartition, dividing each fuperior branch into two, and but two, immediately fubordinate ones; beginning with the logical whole, dividing that into two parts, then each of thofe parts into two

- See ch. xiii. [Cafes unmeet] $§ 2 . i$.

YoL. I.

$\mathrm{Dd}$

others ; 
INTROD. Chap. XVI

To be fo, it muft be detrimental to fome one or more of its members.

Thefe may be affignable or not.
III.

But if the whole affemblage of any number of individuals be confidered as conftituting an imaginary compound body, a community or political ftate; any aet that is detrimental to any one or more of thofe members is, as to fo much of its effects, detrimental to the ftate.

\section{IV.}

An act cannot be detrimental to a fate, but by being detrimental to fome one or more of the individuals that compofe it. But thefe individuals may either be affignable ${ }^{b}$ or unaffignable.

others; and fo on. Thefe firt-diftinguifhed parts agree in refpect of thofe properties which belong to the whole: they differ in refped of thofe properties which are peculiar to each. To divide the whole into more than two parcels at once, for example into three, would not anfwer the purpofe; for, in fact, it is but two objeets that the mind can compare together exactly at the fame time. Thus then, let us endeavour to deal with offences; or rather, Htriklly fpeaking, with acts which poffers fuch properties as feem to indicate them fit to be conftituted offences. The takk is arduous; and, as yet at leaft, perhaps for ever, above our forçe. There is no fpeaking of objects but by their names : but the bufnefs of giving them names has alwaỳs been prior to the true and perfect knowledge of their natures. Objects the moft diffimilar have been fpoken of and treated as if their properties were the fame. Objects the moft fimilar have been fpoken of and treated as if they had fcarce any thing in common. Whatever difcoveries may be made concerning them, how different foever their congruencies and difagreements may be found to be from thofe which are indicated by their names, it is not without the utmoft difficulty that any means can be found out of expreffing thofe difcoveries by a conformable fet of names. Change the import of the old names, and you are in pexpetual danger of being mifunderftood : introduce an intire new fet of names, and you are fure not to be underftood at all. Compleat fuccefs, then, is, as yet at leaft, unattainable. But an attempt, though imperfeet, may ,have its ufe: and, at the wort, it may accelerate the arrival of that perfect fy ftem: the poffeffion of which will be the happiners of fome maturer age. Grofs ignorance defcries no difficulties : imperfect knowledge finds them out, and ftruggles with them : it muft be perfect knowledge that overcomes them.

b [Affignable.] That is, either by name, or at leaft by defcription, in fuch manner as to be fufficiently diftingui(hed from all others; for inftance, by the circumftance of being the owner or occupier of fuch and fuch goods. See B. I. tit. [Perfonation.] Sapra, ch. xii. [Confequences] xv.

V. When 
$v$.

When there is any affignable individual to whom an offence is detrimental, that perfon may either be a perfon otber than the offender, or the offender bimfelf.

VI.

If affignable, the offender himfelf, or others.

Offences that are detrimental, in the firft inftance, to affignable perfons other than the offender, may be termed by one common name, offences againf individuals. And of thefe may be compofed the rift clafs
of offences. To contraft them with offences of the $2 \mathrm{~d}$ and 4 th claffes, Clars I. Private ofit may alf fometimes be convenient to ftile them private offences. To contraft them at the fame time with offences of the $3 \mathrm{~d}$ clafs, they may be ftiled private extra-regarding offences.

VII.

When it appears, in general, that there are perfons to whom the act in queftion may be detrimental, but fuch perfons cannot be individually affigned, the circle within which it appears that they may be found, is either of lefs extent than that which comprizes the whole community, or not. If of lefs, the perfons comprized within this leffer circle may be confidered for this purpofe as compofing a body of themfelves; comprized within, but diftinguifhable from, the greater body of the whole community. The circumftance that conftitutes the union between the members of this leffer body, may be either their refidence within a particular place, or, in thort, any other lefs explicit principle of union, which may ferve to diftinguifh them from the remaining members of the community. In the firft cafe, the act may be ftiled an offence againft a neigbbourbood: in the fecond, an offence againt a particular class of perfons in the community. Offences, then, againit a clafs or neighbourhood, may, together, conftitute the $2 \mathrm{~d}$ clafs of offences ${ }^{c}$. To contraft them with private offences on the one hand,

and

- With regard to offences againft a clars or neighbourhood, it is evident, that the fewer the individuals are, of which fuch clafs is compored, and the nartower that neighbourhood is, the more likely are the perfons, to whom the offence is detrimental, to become affignable; infomuch that, in fome cafes, it may be difficult to determine concerning a given offence, whether it be an offence agiaint individuals, or againft a clafs

Clafs z. Semi-public offences.

\footnotetext{
Limits between private, femipublic, and public offences, are, ftritly fpeaking. undiftinguifh. able.
} 
INTROD. and public on the other $r_{2}$ they may alfo be ftiled femi-public ofCyAP.XVI. fences.

Clars 3. Offences, which in the firft inftance are detrimental to the offender ing offences. himfelf, and to no one elfe, unlefs it be by their being detrimental to
himfelf, may ferve ta compofe a third clafs. To contraft them the better with offences of the firft, fecond, and fourth claffes, all which are of a tranfitive nature, they might be ftiled intranfitive * affences; but ftill better, felf-regarding.

IX.

Clafs 4. The fourth clafs may be compofed of fuch acts as ought to be madePublic offences. offences, on account of the diftant mifchief which they threaten to bring upon an unaffignable indefinite multitude of the whole numberof individuals, of which the community is compofed : although no particular individual thould appear more likely to be a fufferer by them than another. Thefe may be called public offences, or offences againft: the fiate.

$\mathrm{X}$.

Clafs 5. Mulitiform offences, viz. 1. Offences by fallhood. 2. Offences againf truft.

A fifth clafs, or appendix, may be compofed of fuch acts as, ac-cording to the circumftances in which they are committed, and more. particularly according to the purpofes to which they are applied, may: be detrimental in any one of the ways in which the act of one man can be detrimental to another. Thefe may be termed multiform, or beterogeneous offences ${ }^{d}$. Offences that are in this cafe may be reduced to two great heads : 1. Offences by falhood: and, 2. Offences againft truft.

- Seee ch. vii. [AQions] xiii.

or neighbourhood. It is evident alfo, that the larger the clafs or neighbourhood is, the more it approaches to a coincidence with the great body of the ftate. The three claffes, therefore, are liable, to a certain degree, to run into one another, and be confounded. But this is no more than what is the cafe, more or lefs, with all thofe ideal compartments under which men are wont to diftribute objects for the convenience of difcourfe.

The imperfections of laa-

d This clafs will appear, but too plainly, as a kind of botch in comparifon of the. cle to arrangereft. But fuch is the fate of fcience, and more particularly of the moral branch; the difribution of things muft in a great meafure be dependent on their names : arrangement, the work of mature reflection, mult be ruled by nomenclature, the work of popular caprice. 


\section{Divifions and fub-divifions.}

XI.

Let us fee by what method thefe claffes may be farther fub-divided. Firft, then, with regard to offences againft individuals.

In the prefent period of exiftence, a man's being and well-being, his happinefs and his fecurity; in a word, his pleafures and his immunity from pains, are all dependent, more or lefs, in the firtt place, upon his own perfon; in the next place, upon the exterior objects that furround him. Thefe objects are either tbings, or other perfons. Under one or other of thefe claffes muft evidently be comprifed every fort of exterion object, by means of which his intereft can be affected.

In the book of the laws, offences muft therefore be treated of as much as poffible under their accuftomed' names. Generical terms, which are in continual ufe, and which exprefs ideas for which there are no other terms in ufe, cannot fafely be difcarded. When any fuch occur, which cannot be brought to quadrate with fuch a plan of, claffification as appears to be moft convenient upon the whole, what then is to be done? There feems to be but one thing; which is, to retain them, and annex them to. the regular part of the fyftem in the form of an appendix. Though they cannot, when entire, be made to rank under any of the claffes eftablined in the reft of the fyftem, the divifions to. which they give title may be broken down intoleffer divifions, which may not be alike intractable. By this means, how difcordant foever with the reft of the fystem they may appear to be at firf fight, on a clofer infpection they may be found. conformable.

This muft inevitably, be the cafe with the names of offences; which are fo various and: Irregularity of univerfal in their, nature, as to be capable, each of them, of doing whatever mifchief can be done by any other kind or kinds of offences whatfoever. Offences of this defcription may well be called anomalous.

Such offences, it is plain, cannot but fhew themfelves equally intractable under every kind of fyftem. Upon whatever principle the fyftem be conftructed, they cannot, any of not be avoided: them, with any degree of propriety, be confined to any one divifion. If, therefore, they plan. conftitute a blemin in the prefent fyftem, it is fuch a bleminh as could not be avoided. but at the expence of a greater. The clals they are here thrown into will traverfe, in its fubordinate ramifications, the other claffes and divifions of the prefent fyltem : true, but fo would they of any other. An irregularity, and that but a fuperficial one, is a lefs evil than continual error and contradiction. But even this flight deviation, which the falhion of language feemed to render unavoidable at the outfet, we thall foon find occafion to correct as we advance. For though the firt great parcels into which the offences of this clafs are divided are not referable, any of them, to any of the former clafles, yet the fubfequent leffer fubdivifions are. 
INTROD. If then, by means of any offence, a man fhould on any occafion beC\&AP.XVI. come a fufferer, it muft be in one or other of two ways : 1. abfolutely, to wit, immediately in his own perfon; in which cafe the offence may be faid to be an offence againft his perfon: or, 2. relatively, by reafon of fome material * e relation he bears to the before-mentioned exterior objects. Now in as far as a man is in a way to derive either happinefs or fecurity from any object which belongs to the clafs of tbings, fuch thing is faid to be his property, or at leaft he is faid to have a property or an intereft therein: an offence, therefore; which tends to leffen the facility he might otherwire have of deriving happinefs or fecurity from an object which belongs to the clars of things, may be ftiled an offence againft his property. With regard to perfons, in as far as, from objects of this clafs, a man is in a way to derive happinels

- See ch. vii. [Actions] iii. and xxiy.

In what manner plearare and pain depend upon the relato exterior objests.
- If, by reafon of the word relation, this part of the divifion thould appear obfcure, the unknown term may be got rid of in the following manner. Our ideas are derived, all of them, from the fenfes; pleafurable and painful ones, therefore, among the reft : confequently, from the operation of fenfible objets upon our fenfes. A man's happinefs, then, may be faid to depend more or lefs upon the relation he bears to any fenfible object, when fuch object is in a way that ftands a chance, greater or lefs, of producing to him, or averting from him, pain or pleafure. Now this, if at all, it muft do in one or other of two ways: 1. In an aftive way, properly fo called; viz. by motion: or, 2. In a pajfive or quiefcent way, by being moved to, or atted apon: and in either cafe, either, 1. in an immediate way, by ating upon, or being aeted on by, the organs of fenfe, without the intervention of any other external object : or, 2 . in a more or lefs remote way, by acting apon, or being acted on by, fome other external object, which (with the intervention of a greater or lefs number of fuch objects, and at the end of more or lefs confiderable intervals of time) will come at length to act upon, or be aeted upon by, thofe organs. And this is equally true, whether the external abjects in quetion be things or perfons. It is alfo equally true of pains and pleafures of the mind, as of thofe of the body: all the difference is, that in the production of thefe, the pleafure or pain may refult immediately from the perception which it accompanies : in the production of thofe of the mind, it cannot refult from the action of an object of fenfe, any otherwife than by afociation; to wit, by means of fome connection which the perception has contracted with certain prior ones, lodged already in the memory $t$.

+ See ch, v. [Pleafures and Painz] xy. xxxi. Ch, $x$. [Motives] xxxix, note. 
or fecurity, it is ip vittue of their feftices: in virtue of fome fervices, which, by one fort of inducement or another, they may be difpofed to render him ${ }^{*}$. Now, then, take any man, by way of example, and the difpoftion, whatever it may be, which he may be in to render you fervice, ether has no other connection to give birth or fupport to it, than the general one which binds him to the whole fpecies; of it has forne other connection more particular: In the latter eafe, fuch a connection may be fpoken of as conftituting, in your favour, a kind of fietitious or incorporeal object of property, which is ftiled your condition. An offence, therefore, the tendency of which is to leffen the facility you might otherwife have of deriving happinefs from the fervices of a perfon thus fpecially conneeted with you, may be ftiled an offence againft your condition in life; or fimply againft your condition. Conditions in life mult evidently be as various as the relations by which they are confituted. This will be feen more particularly farther on. In the mean time, thofe of hubband, wife, parent, child, marter, fervant, citizen of fuch or fuch a city, natural-born fubject of fuch or fuch a country, may anfwer the purpofe of examples.

Where there is no fuch particular connection, or (what comes to the fame thing) where the difpofition, whatever it may be, which a man is in to render you fervice, is not confidered as depending upon fuch connection, but fimply upon the good-will he bears to you; in fuch cafe, in order to exprefs what chance you have of derixing a benefit from his fervices, a kind of fictitious object of property is fpoken of, as being conftituted in your favour, and is called your reputation. An offence, therefore, the tendency of which is to leffen the facility you might otherwife have had of deriving happinefs or fecurity from the fervices of perfons at large, whether connected. with you or not by any. fpecial tie, may be ftiled an offence againft your reputation. It appears, therefore, that if by any offence an individual becomes a fufferer, it mutt be in one or other of the four points above mentioned; viz. his perfon, his property, his condition in life, or his reputation. Thefe fources of diftinction, then, may ferve to form fo many fubordinate

$$
\text { - See ch. x. [Motives.] }
$$


INTROD. divifions. If any offences thould be found to affect a perfon in more CrAp. XVI. than one of thefe points at the fame time, fuch offences may refpectively be put under fo many feparate divifions; and fuch compound divifions may be fubjoined to the preceding fimple ones. The feveral divifions (fimple and compound together) which are hereinafter eftablifhed, ftand as follows: $\mathbf{x}$. Offences againft perfon. 2. Offences againft property. 3. Offences againft reputation. 4. Offences againft condition. 5. Offences againft perfon and property together. 6. Offences againft perfon and reputation together.

XII. Divifions of Next with regard to femi-public offences. Pain, confidered with
Clafs 2. 1. Offences through calamity. reference to the time of the act from which it is liable to iffue, muft, it is evident, be either prefent, paft, or future. In as far as it is either prefent or paft, it cannot be the refult of any act which comes under the defcription of a femi-public offence : for if it be prefent or paft, the individuals who experience, or who have experienced, it are aflgnable *. There remains that fort of mifchief, which, if it ever come to exift at all, is as yet but future: mifchief, thus circumftanced, takes the name of danger + . Now, then, when by means of the act of any perfon a whole neighbourhood, or other clafs of perfons, are expofed to danger, this danger muft either be intentional on his part, or unintentional $\$$. If unintentional, fuch danger, when it is converted into actual mifchief, takes the name of a calamity: offences, productive of fuch danger, may be ftiled femi-public offences operating through calamity; or, more briefly, offences througb calamity. If the danger be intentional, infomuch that it might be produced, and might convert itfelf into actual mifchief, without the concurrence of any calamity, it may be faid to originate in mere delinquency: offences, then, which, without the concurrence of any calamity, tend to produce fuch danger as difturbs the fecurity of a local, or other fubordinate clafs of perfons, may be ftited femi-public offences operating merely by delinquency, or more brielly, offences of mere delinquency.

- Supra, iv. note. + See ch. xii. [Confequences.] †See ch. viii. [Intentionality.] 
XIII.

With regard to any farther fub-divifions, offences againft calamity will depend upon the nature of the feveral calamities to which man, and the feveral things that are of ufe to him, ftand expofed. Thefe will be confidered in another place ${ }^{e}$.

XIV.

Semi-public offences of mere delinquency, will follow the method of divifion applied to offences againft individuals. It will eafily be conceived, that whatever pain or inconvenience any given individual may be made to fuffer, to the danger of that pain or inconvenience may any number of individuals, affignable or not affignable, be expofed. Now there are four points or articles, as we have feen, in refpect to which an individual may be made to fuffer pain or inconvenience. If then, with refpect to any one of them, the connection of caufes and effects is fuch, that to the danger of fuffering in that article a number of perfons, who individually are not aflignable, may, by the delinquency of one perfon, be expofed, fuch article will form a ground of diftinction on which a particular fub-divifion of femi-public offences may be eftablifhed: if, with refpect to any fuch article, no fuch effect can take place, that ground of diftinction will lie for the prefent unoccupied : ready, however, upon any change of circumftances, or in the manner of viewing the fubject, to receive a correfpondent fub-divifion of offences, if ever it thould feem neceffary that any fuch offences thould be created.

\section{$\mathrm{XV}$.}

We come next to felf-regarding offences; or, more properly, to acts productive in the firft inftance of no other than a felf-regarding mifchief: acts which, if in any inftance it be thought fit to conftitute them offences, will come under the denomination of offences againft one's
INTROD.

CHAP.XVI.

Sub-divifions of offences

through ca-

lamity, difmifred.

Offences of mere delinquency, how they correfpond with the divifions of private offences.

e See B. I. tit. [Semi-public offences.] In the mean time that of pefilence may ferve as an example. A man, without any intention of giving birth to fuch a calamity, may expofe a neighbourhood to the danger of it, by breaking quarentine, or violating any of thofe other preventive regulations which governments, at certain conjunctures, may find it expedient to have recourfe to, for the purpofe of guarding againt fuch danger. See infra, xxxiii, note.

Vou. I.

$\mathrm{E}$ e

felf.

Divifions of Clafs 3 coincide with thore of Clars $x$. 
INTROD. felf. This clafs will not for the prefent give us much trouble. For CGap. XVI. it is evident, that in whatever points a man is vulnerable by the hand of another, in the fame points may he be conceived to be vulnerable. by his own. Whatever divifions therefore will ferve for the firft clafs, the fame will ferve for this. As to the queftions, What acts are productive of a mifchief of this ftamp? and, among fuch as are, which it may, and which it may not, be wortb wbile * to treat upon the footing of offences ? thefe are points, the latter of which at leaft is, too unfettled, and too open to controverfy, to be decided with that degree of confidence which is implied in the exhibition of properties that are made to ferve as the groundwork of an arrangement. Properties for this purpofe ought to be fuch as thew themfelves at firft glance, and appear to. belong to the fubject beyond difpute.

XVI.

Divifions of Public offènces may be diftributed under eleven divifions: $f_{\text {: }} \quad$ I. Of: Clafs 4. fences againft external jecurity. 2. Offences againft juffice. 3. Offences.

- See ch, xiii. [Cares unmeet]' s 4 !

- In this part of the analyfis, $I$ have found it neceffary to deviate in fome: degree from the rigid rules of the exhautive methad I fet out with. By me, or by fome one elfe, this method may, perhaps, be more ftrialy purfued at fome: maturer period of the fcience. At prefent, the benefit that might refult from the un-relaxed obfervance of it, feemed fo precarious, that I could not help doubting whetherit would pay for the delay and trouble. Doubtlefs fuch a method is eminently in-. fructive: but the fatigue of following it out is fo great, not only to the author, but. probably alfo to the reader, that if carriegd to its utmof length at the firft attempt, it. might perhaps do more differvice in the way of difgut, than fervice in the way of information. For knowledge, like phyfic, how falutary foever in itfelf, becomes no. longer of any ufe, when made too unpalatable to be fwallowed. Mean time, it cannot but be a mortifying circumftance to a writer, who is fenfible of the importance of his fubject, and anxious to do it juftice, to find himfelf obliged to exhibit what he perceives to be faulty, with any view, how indiftinet foever, of fomething more perfect before his eyes. If there be any thing new and original in this work, it is to the exhaultive method fo often aimed at that I am indebted for it. It will, therefore, be na great wonder if $\mathrm{I}$ thould not be able to quit it without reluctance. On the other hand, the marks of ftiffnefs which will donbtlefs be perceived in a multitude of places, are chiefly owing to a folicitous, and not perfectly fuccefsful, purfuit of this fame method. New inftruments are feldom handled at firft with perfect eafe. 
againt the preventive branch of the police. 4. Offences againft the public INTROD. force. 5. Offences againt the pofitive encreafe of the national felicity. 6. Offences againft the public wealth. 7. Offences againft population. 8. Offences againt the national wealth. 9. Offences againt the fovereignty. 10. Offences againft religion. I 1 . Offences againft the national intereft in general. The way in which thefe feveral forts of offences connect with one another, and with the intereft of the public, that is, of an unaffignable multitude of the individuals of which that body is compofed, may be thus conceived.

\section{XVII.}

Mifchief, by which the intereft of the public as above defined may be affected, mult, if produced at all, be produced either by means of an influence exerted on the operations of government, or by other means, without the exertion of fuch infuence ${ }^{g}$. To begin with the latter cafe : mifchief, be it what it will, and let it happen to whom it will, muft be produced either by the unaffifted powers of the agent in queftion, or by the inftrumentality of fome other agents. In the latter cafe, thefe agents will be either perfons or things. Perfons again muft be either not members of the community in queftion, or members. Mifchief produced by the inftrumentality of perfons, may accordingly be produced by the inftrumentality either of external or of internal adverfaries. Now when it is produced by the agent's own unaffifted powers, or by the inftrumentality of internal adverfaries, or only by the inftrumentality of things, it is feldom that it can thew itfelf in any other fhape (fetting afide any influence it may exert on the operations of government) than either that of an offence againft affignable individuals, or that of an offence againft a local or other fubordinate clafs of perfons. If there hould be a way in which mifchief can be produced, by any of thefe means, to individuals aitogether unaffignable, it

g. The idea of government, it may be obferved, is introduced here without any preparation. The fact of its being eftablifhed, I affume as notorions, and the neceffity of it as alike obvious and inconteftible. Obfervations indicating that neceffity, if any fuch thould be thought worth looking at in this view, may be found by turning to a paffage in a former chapter, where they were incidentally adduced for the purpore of illuftration. See ch. xii. [Confequences] $\$$ xvii. 
INTROD. will fcarcely be found confpicuous or important enough to occupy a

Crap.XVI. title by itfelf: it may accordingly be referred to the mifcellaneous head of offences againft the national intereft in general $k$. The only mifchief, of any confiderable account, which can be made to impend indifcriminately over the whole number of members in the community; is that complex kind of mifchief which refults from a ftate of war, and is produced by the inftrumentality of external adverfaries; by their being provoked, for inftance, or invited, or encouraged to invafion. In this way may a man very well bring down a mifchief, and that a very heavy one, upon the whole community in general, and that without taking a part in any of the injuries which came in confequence to be offered to particular individuals.

Next with regard to the mifchief which an offence may bring upon the public by its influence on the operations of the government. This it may occafion either, r. In a more immediate- way, by its influence on thofe operations themfelves: 2. In a more remote way, by its influence on the inftruments by or by the help of which thofe operations hould be performed: or 3 . In a more remote way ftill, by its influence on the fources from: whence fuch inftruments are to be derived. Firft then; As to the operations of government, the tendency of thefe, in as far as it is conformable to what on the principle of utility it ought to be, is in every cafe either to avert mifchief from the community, or to make an addition to the fum of pofitive good ${ }^{1}$. Now mifchief, we have feen,

mult

\footnotetext{
h See infra, liv. note. Even this head; ample as it is, and vague as it may feem to be, will not, when examined by the principle of utility, ferve, any more than another; to fecrete any offence which has no title to be placed there. To thew the pain or lofs of pleafure which is likely to enfue, is a problem, which before a legillator can juftify. himfelf in adding the act to the catalogue of offences, he may in this cafe, as in every, other, be called upon to folve.

i For examples, fee infra liv, note. This branch of the bufinefs of government, a fort of work of fupererogation, as it may be called, in the calendar of political duty, is comparatively but of recent date. It is not for this that the untutored many could have originally fubmitted themfelves to the dominion of the few. It was the dread of evil, not the hope of good, that firft cemented focieties together. Neceffaries come always before luxuries. The ftate of language marks the progrefs of ideas. Time out
} 
muft come either from external adverfaries, from internal adverfaries, INTROD. or from calanies. With regard to mifchief from external adver- CнAp. XVI, faries, there requires no further divifion. As to mifchief from internal adverfaries, the expedients employed for averting it may be diftinguifhed into fuch as may be applied before the difcovery of any mifchievous defign in particular, and fuch as cannot be employed but in confequence of the difcovery of fome fuch defign: the former of thefe are commonly referred to a branch which may be ftiled the preventive branch of the police: the latter, to that of juftice ${ }^{\mathrm{k}}$. Secondly, As to the inftruments which government, whether in the averting of evil or in the producing of politive good, can have to work with, thefe muft be either perfons or tbings. Thofe which are deftined to the particular function of guarding againft mifchief from adverfaries in:

of mind the military department has had a name: fo has that of juftice: the power which occupies itfelf in preventing mifchief, not till lately, and that but aloofe one, the police: for the power which takes for its object the introduction of pofitive goods no peculiar name, however inadequate, feems yet to have been devifed.

$k$ The functions of juftice, and thofe of the police, mult be apt in many points to run one into another: efpecially as the bufinefs would be very badly managed. if the fame perfons, whofe more particular duty it is to act as officers of the police, were not upon occafion to act in the capacity of officers of juftice. The ideas however of: the two functions may ftill be kept diftinct : and I fee not where the line of feparation can be drawn, unlefs it be as above.

As to the word police, though of Greek extraction, it feems to be of French growth: it is from France, at leaft, that it has been imported into Great Britain, where it Atill. retains its foreign garb : in Germany, if it did not originate there, it has at leaft been: naturalized. Taken all together, the idea belonging to it feems to be too multifarious to be fufceptible of any fingle definition. Want of words obliged me to reduce the. two branches here fpecified into one. Who would have endured in this place to have feen two fuch words as the pbtbano-paranamic or crime-preventing, and the phtbanoSympboric or calamity-preventing, branches of the police? The inconvenience of uniting the two branches under the fame denomination, are, however, the lefs, inalmuch as the operations requifite to be performed for the two purpofes will in many cafes be the fame. Other functions, commonly referred to the head of police, may be referred' either to the head of that power which occupies itfelf in promoting in a pofitive way the encreafe of the national felicity, or of that which employs itfelf in the mamagement of the public wealth. See infra, liv, note. 
INTROD. general, but more particularly from external adverfaries', may be difCHAP.XVI. tinguifhed from the reit under the collective appellation of the public military force, and, for concifenefs fake, the military force. The reft may be characterifed by the collective appellation of the public wealth. Thirdly, With regard to the fources or funds from whence thefe inftruments, howfoever applied, muft be derived, fuch of them as come under the denomination of perfons muft be taken out of the whole number of perfons that are in the community, that is, out of the total population of the ftate: fo that the greater the population, the greater may ceteris paribus be this branch of the public wealth; and the lefs, the lefs. In like manner, fuch as come under the denomination of things may be, and moit of them commonly are, taken out of the fum total of thofe things which are the feparate properties of the feveral members of the community: the fum of which properties may be termed the national wealt ${ }^{\mathrm{m}}$ : fo that the greater the national wealth, the greater cateris paribus may be this remaining branch of the public wealth; and the lefs, the lefs. It is here to be obferved, that if

1 It is from abroad that thofe pernicious enterprizes are moft apt to originate, which come backed with a greater quantity of phyfical force than the perfons who are in a more particular fenfe the officers of juftice are wont to have at their command. Mifchief, the perpetration of which is enfured by a force of fuch magnitude, may therefore be looked upon in general as the work of external adverfaries. Accordingly, when the perfons, by whom it is perpetrated, are in fuch force as to bid defiance to the ordinary efforts of juftice, they loofen themfelves from their original denomination in proportion as they increafe in force, till at length they are looked upon as being no longer members of the ftate, but as ftanding altogether upon a footing with external adverfaries. Give force enough to robbery, and it fwells into rebellion: give permanence enough to rebellion, and it fettles into hoftility.

m It muft be confeffed, that in common speech the diftinction here eftablined between the public wealth and the national wealth is but indifferently fettled: nor is this to be wondered at; the ideas themfelves, though here neceffary to be diftinguifhed, being fo frequently convertible. But $I$ am miftaken if the language will furnith any other two words that would exprefs the diftinction better. Thofe in queftion will, I imagine, be allowed to be thus far well-chofen, that if they were made to change their places, the import given to them would not appear to be quite fo proper as that which is given to them as they fand at prefent. 
the influence exerted on any occafion by an individual over the INTROD. operations of the government be pernicious, it muft be in one or CHAP.XVI. other of two ways: 1. By caufing, or tending to caufe, operations not to be performed which ougbt to be performed; in other words, by impeding the operations of government. Or, 2. By caufing operations to be performed which ought not to be performed; in other words, by mifdirecting them. Laftly, to the total affemblage of the perfons by whom the feveral political operations above-mentioned come to be performed, we fet out with applying the collective appellation of the government. Among thefe perfons there commonly ${ }^{\mathrm{n}}$ is fome one perfon, or body of perfons, whofe office it is to affign and diftribute to the reft their feveral departments, to determine the conduct to be purfued by each in the performance of the particular fet of operations that belongs to him, and even upon occafion to exercife his function in his ftead. Where there is any fuch perfon, or body of perfons, be or it may, according as the turn of the phrafe requires, be termed the fovereign, or the fovereignty. Now it is evident, that to impede or mifdirect the operations of the fovereign, as here defcribed, may be to impede or mifdirect the operations of the feveral departments of government, as defcribed above.

From this analyfis, by which the connection between the feveral above-mentioned heads of offences is exhibited, we may now collect a definition for each article. By offences againft external fecurity, we may underftand fuch offences whereof the tendency is to bring upon the public a mifchief refulting from the hoftilities of foreign adverfaries. By offences againft juftice, fuch offences whereof the tendency is to impede or mifdirect the operations of that power which is employed in the bufinefs of guarding the public againft the mifchiefs refulting from the delinquency of internal adverfaries, as far as it is to be done by expedients, which do not come to be applied in any cafe till after the

n I thould have been afraid to have faid neceffarily. In the United Provinces, in the Helvetic, or even in the Germanic body, where is that one affembly in which an abfom. lute power over the whole refides? Where was there in the Roman Commonwealth? I would not undertake for certain to find an anfwer to all thefe queftions. 
INTROD: difcovery of fome particular defign of the fort of thofe which they are CHAP. XVI. calculated to prevent. By offences againft the preventive branch of the police, fuch offences whereof the tendency is to impede or mifdirect the operations of that power which is employed in guarding againft mifchiefs refulting from the delinquency of internal adverfaries, by expedients that come to be applied before-baind; or of that which is employed in guarding againft the mirchiefs that might be occafioned by phyfical calamities. By offences againft the public force, fuch offences whereof the tendency is to impede or mifdirect the operations of that power which is deftined to guard the public from the mifchiefs which may refult from the hoftility of foreign adverfaries, and, in cafe of neceffity, in the capacity of minifters of juftice, from mifchiefs of the number of thofe which refult from the delinquency of internal adverfaries. By offences againft the increase of the national felicity, fuch offences whereof the tendency is to impede or mifapply the operations of thofe powers that are employed in the conducting of various eftablinments, which are calculated to make, in fo many different ways, a pofitive addition to the ftock of public happinefs. By offences againft the public wealtb, fuch offences whereof the tendency is to diminifh the amount or mifdirect the application of the money, and other articles of wealth, which the government referves as a fund out of which the ftock of inftruments employed in the fervice above-mentioned may be kept up. By offences againft population, fuch offences whereof the tendency. is to diminin the numbers or impair the political value of the fum total of the members of the community. By offences againft the national wealth, fuch offences whereof the tendency is to diminifh the quantity, or impair the value, of the things which compofe the feparate properties or eftates of the feveral members of the community.

\section{XVIII.}

In this deduction, it may be afked, What place is left for religion?

Connection of offences againft religion with the foregoing ones, This we thall fee prefently. For combating the various kinds of offences above enumerated, that is, for combating all the offences (thofe not excepted which we are now about confidering) which it is in man's 
nature to commit, the ftate has two great engines, punifbment and re- INTROD. ward: punifhment, to be applied to all, and upon all ordinary oc- CHap.XVI. cafions: reward, to be applied to a few, for particular purpofes, and upon extraordinary occafions. But whether or no a man has done the act which renders him an object meet for punifhment or reward, the eyes of thofe, whofoever they be, to whom the management of thefe engines is entrufted cannot always fee, nor, where it is punifhment that is to be adminiftered, can their hands be always fure to reach him. To fupply thefe deficiencies in point of power, it is thought neceffary, or at leaft ufeful (without which the truth of the doctrine would be nothing to the purpofe) to inculcate into the minds of the people the belief of the exiftence of a power applicable to the fame purpofes, and not liable to the fame deficiencies: the power of a fupreme invifible being, to whom a difpofition of contributing to the fame ends to which the feveral inftitutions already mentioned are calculated to contribute, muft for this purpofe be afcribed. It is of courfe expected that this power will, at one time or other, be employed in the promoting of thofe ends : and to keep up and ftrenghen this expectation among men, is fpoken of as being the employment of a kind of allegorical perfonage, feigned, as before *, for convenience of difcourfe, and ftiled Religion. To diminifh, then, or mifapply the influence of religion, is pro tanto to diminifh or mifapply what power the ftate has of combating with effect any of the beforeenumerated kinds of offences; that is, all kinds of offences whatfoever. Acts that appear to have this tendency may be ftiled offences againft religion. Of thefe then may be compofed the tenth divifion of the clafs of offences againft the ftate ${ }^{\circ}$.

$$
\text { - See par. xvii. with regard to juftice. }
$$

XIX. If

- It may be obferved, that upon this occafion I confider religion in no other light, than in refpect of the infuence it may have on the happinefs of the prefent life. As to the effects it may have in affuring us of, and preparing us for, a better life to come, this is a matter which comes not within the cognizance of the leginator.-See tit. [Offences againt religion.]

I fay, offences againft religion, the fietitious entity : not offences again $\mathrm{God}$, the real being. For, what fort of pain hould the act of a feeble mortal occafion to a being unfufceptible of pain? How thould an offence affect him? Should it be an offence againft his perfon, his property, his reputation, or his condition?

Vol. I. 
ccxviii

INTROD.

CHAP. XVI.

Connection of offences againft the national intereft in general with the reft.
[D I V I S I $O$ O N] of offences.

\section{XIX.}

If there be any acts which appear liable to affect the ftate in any one or more of the above ways, by operating in prejudice of the external fecurity of the ftate, or of its internal fecurity; of the public force; of the encreafe of the national felicity; of the public wealth; of the national population; of the national wealth; of the fovereignty; or of religion; at the fame time that it is not clear in which of all thefe ways they will affect it moft, nor but that, according to contingencies, they may affect it in one of thefe ways only or in another; fuch acts may be collected together under a mifcellaneous divifion by themfelves, and ftiled offences againft the national intereft in general. Of thefe then may be compored the eleventh and laft divifion of the clafs: of offences againft the ftate.

$\mathrm{XX}$.

Sub-divifions of Clafs 5 enumerated. 1. Divifions of offences by fallhood.
We come now to clafs the fifth: confifting of multiform offences. Thefe, as has been already intimated, are either offences by falbood, or offences concerning truft. Under the head of offences by falihood, may be comprehended, 1. Simple falfhoods. 2. Forgery. 3. Perfonation. 4. Perjury ${ }^{p}$. Let us obferve in what particulars thefe four kinds of falthood agree, and in what they differ.

XXI. Of

It has commonly been the way to put offences againft religion foremont. The idea of precedence is naturally enough connected with that of reverence. Ex $\Delta \operatorname{los} \alpha \xi \chi \omega \mu \varepsilon a \alpha_{0} .-$ But for expreffing reverence, there are other methods enough that are lefs equivocal. And in point of method and perfpicuity, it is evident, that with regard to offences againft religion, neither the nature of the mifchief which it is their tendency to produce, nor the reafon there may be for punifhing them, can be underftood, but from the confideration of the feveral mifchiefs which refult from the feveral other forts of of fences. In a political view, it is only becaufe thofe others are mifchievous, that offences againft religion are fo too.

$p$ This divifion of fallhoods, it is to be obferved, is not regularly drawn out; that being what the nature of the cafe will not here admit of. Falfhood may be infinitely diverfified in other ways than thefe. In a particular cafe, for inftance, fimple falihood when uttered by writing, is diftinguined from the fame falthood when uttered by word of mouth; and has had a particular name given to it accordingly. I mean, where it Atrikes againft reputation; in which cafe, the inftrument it has been uttered by has been called a libel. Now it is obvious, that in the fame manner it might 
$\mathrm{XXI}$.

INTROD.

Offences by falhood, however diverfified in other particulars, have this in common, that they confift in fome abufe of the faculty of difcourfe, or rather, as we thall fee hereafter, of the faculty of influencing the fentiment of belief in other men ${ }^{*}$, whether by difcourfe or otherwife. The ufe of difcourfe is to influence belief, and that in fuch manner as to give other men to underftand that things are as they are really. Fallhoods, of whatever kind they be, agree in this; that they give men to underftand that things are otherwife than as in reality they are.

\section{XXII.}

Perfonation, forgery, and perjury, are each of them diftinguifhed from other modes of uttering falhood by certain fpecial circumftances. When a fallhood is not accompanied by any of thofe circumftances, it may be ftiled fimple falhood. Thefe circumftances are, 1 . The form in which the fallhood is uttered. 2. The circumftance of its relating or not to the identity of the perfon of him who utters it. 3. The folemnity of the occafion on which it is uttered ?. The particular application of thefe diftinctive characters may more commodiounly be referved for another place + .

have received a diftinet name in all other cafes where it is uttered by writing. But there has not happened to be any thing in particular that has difpored mankind in thore cafes to give it fuch a name. The cafe is, that among the infinity of circumftances by which it might have been diverfified, thofe which conftitute it a libel, happen to have engaged a peculiar hare of attention on the part of the inftitutors of language; either in virtue of the influence which the fe circumftances have on the tendency of the act, or in virtue of any particular degree of force with which on any other account they may have difpofed it to frike upon the imagination.

9 There are two other circumftances ftill more material; viz. 1. The parties whore intereft is affected by the fallhood: 2. The point or article in which that intereft is affected. Thefe circumftances, however, enter not into the compofition of the generical character. Their ufe is, as we thall fee, to characterize the feveral fpecies of each genus. See B. I. tit. [Fallhoods.]

- See B. I. tit. [Fallhoods.] t Ib.

Offences by fallhood, in what they agree with one another. they differ.

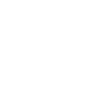


Crap. XVI. We come now to the fub-divifions of offences by fallhood. Thefe Sub.divifions will bring us back into the regular track of analyfis, purfued, without of offences by falfhood are determined by the dideviation, through the four preceding claffes. fons of the be or be not of the number, the individuals liable to be affected by it preceding muft either be affignable or unaffignable. If affignable, there are but four material articles in refpect to which they can be affected: to wit, their perfons, their properties, their reputations, and their conditions in life. The cafe is the fame, if, though unaffignable, they are comprifable in any clafs fubordinate to that which is compofed of the whole number of members of the tate. If the fallhood tend to the detriment of the whole ftate, it can only be by operating in one or other of the characters, which every act that is an offence againft the ftate muft affume; viz. that of an offence againft external fecurity, againft juftice, againt the preventive branch of the police, againft the public force, againft the encreafe of the national felicity, againt the public wealth, againt the national population, againft the national wealth, againft the fovereignty of the ftate, or againit its religion.

\section{XXIV.}

Offences of this clafs, in fome in-

ftances,

change their

names; in

others, not.
It is the common property, then, of the offences that belong to this divifion, to run over the fame ground that is occupied by thofe of the preceding claffes. But fome of them, as we thall fee, are apt, on various occafions, to drop or change the names which bring them under this divifion: this is chiefly the cafe with regard to fimple fallhoods. Others retain their names unchanged, and even thereby fuperfede the names which would otherwife belong to the offences which they denominate: this is chiefly the cafe with regard to perfonation, forgery, and perjury. When this circumftance then, the circumftance of falfhood, intervenes, in fome cafes the name which takes the lead, is that which indicates the offence by its effeet: in other cafes, it is that which indicates the expedient or inftrument as it were by the help of which the offence is committed. Falhood, take it by itfelf, confider it as not being accompanied by any other material circumftances, nor therefore 


\section{[D I V I S I O N] of offences.}

therefore productive of any material effects, can never, upon the principle of utility, conftitute any offence at all. Combined with other circumftances, there is fcarce any fort of pernicious effect which it may not be inftrumental in producing. It is therefore rather in compliance with the laws of language, than in confideration of the nature of the things themfelves, that falhoods are made feparate mention of, under the name and in the character of diftinct offences. All this would appear plain enough, if it were now a time for entering into particulars : but that is what cannot be done, confiftently with any principle of order or convenience, until the inferior divifions of thofe other claffes fhall have been previounly exhibited.

\section{XXV.}

We come now to offences againft truft. A truft is, where there is A truft, any particular act which one party, in the exercife of fome power, or what. fome right ${ }^{\mathrm{r}}$, which is conferred on him, is bound to perform for the benefit

\footnotetext{
- Powers, though not a fpecies of rights (for the two forts of fictitious entities, termed a power and a right, are altogether difparate) are yet fo far included under rights, that wherever the word power may be employed, the word right may alfo be employed : given of them. The reafon is, that wherever you may fpeak of a perfon as having a power, you may alfo fpeak of him as having a right to fuch power: but the converfe of this propofition does not hold good: there are cafes in which, though you may fpeak of a man as having a right, you cannot fpeak of him as having a power, or in any other way make any mention of that word. On various occafions you have a right, for inftance, to the fervices of the magittrate: but if you are a private perfon, you have no power over him : all the power is on his fide. This being the cafe, as the word rigbt was employed, the word powier might, perhaps, without any deficiency in the fenfe, have been omitted. On the prefent occafion however, as in fpeaking of trufts this word is commonly made more ufe of than the word right, it feemed moft eligible, for the fake of perfpicuity, to infert them both.

It may be expected that, fince the word truft has been here expounded, the words porwer and rigbt, upon the meaning of which the expofition of the word truft is made to depend, fhould be expounded alfo: and certain it is, that no two words can ftand more in need of it than thefe do. Such expofition I accordingly fet about to give, and indeed have actually drawn up: but the details into which $I$ found it neceffary to enter for this purpofe, were of fuch length as to take up more room than could confiftently be allotted to them in this place. With refpect to thefe words, therefore, and a number of others, fuch as poffeffion, title, and the like, which in point of import are in-
} Power and right, why nocompieat 
INTROD. benefit of another. Or, more fully, thus: A party is faid to be inChap. XVI. vefted with a truft, when, being invefted with a power, or with a right, there is a certain behaviour which, in the exercife of that power, or of that right, he is bound to maintain for the benefit of fome other

party.

feparably connected with them, inftead of exhibiting the expofition itfelf, I muft content myfelf with giving a general idea of the plan which $I$ have purfued in framing it : and as to every thing elfe, I muft leave the import of them to reft upon whatever footing it may happen to ftand upon in the apprehenfion of each reader. Power, and right, and the whole tribe of fictitious entities of this ftamp, are all of them, in the fenfe which belongs to them in a book of jurifprudence, the refults of fome manifeftation or other of the legillator's will with refpect to fuch or fuch an act. Now every fuch manifeftation is either a prohibition, a command, or their refpective negations; viz. a permiffion, and the declaration which the legiflator makes of his will when on any occafion he leaves an act uncommanded. Now, to render the expreffion of the rule more concife, the commanding of a pofitive act may be reprefented by the prohibition of the negative act which is oppofed to it. To know then how to expound a right, carry your eye to the aet which in the circumftances in queftion would be a violation of that right: the law creates the right by prohibiting that act. Power, whether over a man's own perfon, or over other perfons, or over things, is conftituted in the firf inftance by permifion: but in as far as the law takes an active part in corroborating it, it is created by prohibition, and by command : by prohibition of fuch acts (on the part of other perfons) as are judged incompatible with the exercife of it ; and, upon occafion, by command of fuch acts as are judged to be neceffary for the removal of fuch or fuch obftacles of the number of thofe which may occur to impede the exercife of it. For every right which the law confers on one party, whether that party be an individual, a fubordinate clafs of individuals, or the public, it thereby impofes on fome other party a duty or obligation. But there may be laws which command or prohibit acts, that is, impore duties, without any other view than the benefit of the agent: thefe generate no rights: duties, therefore, may be either extra-regarding or felf-regarding : extra-regarding have rights to correfpond to them : felf-regarding, none.

That the expofition of the words power and right mult, in order to be correct, enter into a great variety of details, may be prefently made appear. One branch of the fyftem of rights and powers, and but one, are thofe of which property is compofed: to be correct, then, it muft, among other things, be applicable to the whole tribe of modifications of which property is fufceptible. But the commands and prohibitions, by which the powers and rights that compofe thofe feveral modifications are created, are of many different forms: to comprize the expofition in queftion within the compafs of a fingle paragraph, would therefore be impofible: to take as many 
party. In fuch cafe, the party firt mentioned is ftiled a truftee: INTROD. for the other party, no name has ever yet been found: for want of CHAP.XVI. a name, there feems to be no other refource than to give a new and more extenfive fenfe to the word beneficiary, or to fay at length the party to be benefited:

The

paragraphs for it as would be neceffary, in order to exhibit thefe different forms, would be to engage in a detail fo ample, that the analyfis of the feveral poffible fpecies of property would compofe only a part of it. This labour, uninviting as it was, I have accordingly undergone: but the refult of it, as may well be imagined, feemed too voluminous and minute to be exhibited in an outline like the prefent. Happily it is not neceffary, except only for the fcientific purpofe of arrangement, to the underftanding of any thing that need be faid on the penal branch of the art of legillation. In a work which Thould treat of the civil branch of that art, it would find its proper place : and in fuch a work, if conducted upon the plan of the prefent one, it would be indifpenfable. Of the limits which feem to feparate the one of thefe branches from the other, a pretty ample defcription will be found in the next chapter: from which fome farther lights refpecting the courfe to be taken for developing the notions to be annexed to the words right and power, may incidentally be collected. See in particular, fections 3 and 4 . See alfo par. LV of the prefent chapter.

I might have cut this matter very fhort, by proceeding in the ufual ftrain, and faying, that a power was a faculty, and that a right was a privilege, and fo on, following the beaten track of definition. But the inanity of fuch a method, in caf s like the prefent, has been already pointed out : a power is not a-any thing: neither is a right a-any thing: the cafe is, they have neither of them any fuperior genus: thefe, together with duty, obligation, and a multitude of others of the fame tamp. being of the number of thofe fictitious entities, of which the import can by no other means be illuftrated than by fhewing the relation which they bear to real ones.

- The firft of thefe parties is ftiled in the law language, as well as in common fpeech, by the name here given to him. The other is ftiled, in the technical language of the Englin law, a ceftuy que truft: in common fpeech, as we have obferved, there is, unfortunately, no name for him. As to the law phrafe, it is antiquated French, and though complex, it is ftill elliptical, and to the higheft degree obfcure. The phrafe in full length would run in fome fuch manner as this : seftuy al ufe de qui le truft eft crée : he to whofe ufe the truft or benefit is created. In a particular cafe, a ceftuy gue truft is called by the Roman law, fdei-commifarius. In imitation of this, I have feen him fomewhere or other called in Englifh a fide-committee. This term, however, feems not very expreffive. A fide-committee, or, as it hould have been, a fidei-committee, feems, literally speaking, to mean one who is committed to the good faith of

- See Fragment on Government, ch. v. $§ 6$, note. another. 
INTROD. The truftee is alfo faid to have a truft conferred or imposed upon CHAp. XVI. him, to be invefted with a truft, to have had a truft given him to execute, to perform, to difcharge, or to fulfil. The party to be benefited, is faid to have a truft eftablinhed or created in his favour : and fo on through a variety of other phrafes.

\section{XXVI.}

Offences Now it may occur, that a truft is oftentimes fpoken of as a fpecies againft trut, of condition ${ }^{\mathrm{t}}$ : that a truft is alfo fpoken of as a fpecies of property: and property, why ranked under feparate divifions. and that a condition itfelf is alfo fpoken of in the fame light. It may be thought, therefore, that in the firft clafs, the divifion of offences againft condition fhould have been included under that of the offences againt property: and that at any rate, fo much of the fifth clafs now before us as contains offences againt truft, thould have been included under one or other of thofe two divifions of the firft

another. Good faith feems to confift in the keeping of a promife. But a truft may be created without any promife in the cafe. It is indeed common enough to exact a promife, in order the more effectually to oblige a man to do that which he is made to promife he will do. But this is merely an accidental circumftance. A truft may be created without any fuch thing. What is it that conftitutes a legal obligation in any cafe? A command, exprefs or virtual, together with punifhment appointed for the breach of it. By the fame means may an obligation be conftituted in this cafe as well as any other. Inftead of the word beneficiary, which I found it neceffary to adopt, the fenfe would be better expreffed by fome fuch word as beneficiendary (a word analogous in its formation to referendary) were it fuch an one as the ear could bring itfelf to endure. This would put it more effectually out of doubt, that the party meant was the party who ought to receive the benefit, whether he actually receives it or no: whereas the word beneficiary might be underfood to intimate, that the benefit was actually received: while in offences againft truft the mifchief commonly is, that fuch benefit is reaped not by the perfon it was defigned for, but by fome other; for inftance, the truftee.

t It is for Shortnefs fake that the propofition is ftated as it ftands in the text. If critically examined, it might be found, perhaps, to be fcarcely juftifiable by the laws of language. For the fictitious entities, characterized by the two abftract terms, truft and condition, are not fubalternate but difparate. To fpeak with perfect precifion, we Mould fay, that he who is invefted with a truft, is, on that account, fpoken of as being inverted with a condition: viz, the condition of a truftee. We fpeak of the condition of a truftee as we fpeak of the condition of a huband or a father.

clafs. 
clafs. But upon examination it will appear, that no one of thefe INTROD. divifions could with convenience, nor even, perhaps, with propriety, have been included under either of the other two. It will appear at the fame time, that there is an intimate connection fubfifting amongft them all: infomuch that of the lifts of the offences to which they are refpectively expofed, any one may ferve in great meafure as a model for any other. There are certain offences to which all trufts as fuch are expofed : to all thefe offences every fort of condition will be found expofed: at the fame time that particular fpecies of the offences againft truft will, upon their application to particular conditions, receive different particular denominations. It will appear alfo, that of the two groupes of offences into which the lift of thofe againft truft will be found naturally to divide itfelf, there is one, and but one, to which property, taken in its proper and more confined fenfe, ftands expofed : and that thefe, in their application to the fubject of property, will be found fufceptible of diftinct modifications, to which the ufage of language, and the occafion there is for diftinguifhing them in point of treatment, make it neceffary to find names.

In the firtt place, as there are, or at leaft may be (as we Mall fee) conditions which are not trufts *, fo there are trufts of which the idea would not be readily and naturally underftood to be included under the word condition: add to which, that of thofe conditions which do include a truft, the greater number include other ingredients along with it : fo that the idea of a condition, if on the one hand it ftretches beyond the idea of a truft, does on the other hand fall fhort of it. Of the feveral forts of trufts, by far the moft important are thofe in which it is the public that ftands in the relation of beneficiary. Now thefe trufts, it hould feem, would hardly prefent themfelves at firft view upon the mention of the word condition. At any rate, what is more material, the moft important of the offences againft thefe kinds of truft would not feem to be included under the denomination of offences againft condition. The offences which by this latter appellation would be brought to view, would be fuch only as feemed to

- Infra, Iv.

Vox. I.

G $\mathrm{g}$

affect 
INTROD. affect the interefts of an individual: of him, for example, who is CHAP. XVI. confidered as being invefted with that condition. But in offences againft public truft, it is the influence they have on the interefts of the public that conftitutes by much the moft material part of their pernicious tendency: the influence they have on the interefts of any individual, the only part of their influence which would be readily brought to view by the appellation of offences againft condition, is comparatively as nothing. The word truft directs the attention at once to the interefts of that party for whom the perfon in queftion is: truftee : which party, upon the addition of the epithet public; is immediately underftood to be the body compofed of the whole affemblage, or an indefinite portion of the whole affemblage, of the members of the ftate. The idea prefented by the words public truft is clear and unambiguous: it is but an obfcure and ambiguous garb that that idea could be expreffed in by the words public condition. It appears, therefore, that the principal part of the offences, included: under the denomination of offences againft truft, could not, commodiounly at leaft, have been included under the head of offences againft. condition.

It is evident enough, that for the fame reafons neither could they have been included under the head of offences againt property. It would have appeared prepofterous, and would have argued a total inattention to the leading principle of the whole work, the principle of utility, to have taken the moft mifchievous and alarming part of the offences to which the public ftands expofed, and forced them into the lift of offences againft the property of an individual: of that individual, to wit, who in that cafe would be confidered as having in him the property of that public truft, which by the offences in queftion. is affected.

Nor would it have been lefs improper to have included conditions, all of them, under the head of property: and thereby the whole catalogue of offences againft condition, under the catalogue of offences againft property. True it is, that there are offences againit condition, which perhaps with equal propriety, and without any change in their nature, might be confidered in the light of offences againt 
againft property: fo extenfive and fo vague are the ideas that are wont to be annexed to both thefe objects. But there are other offences which, though with unqueftionable propriety they might be referred to the head of offences againft condition, could not, without the utmoft violence done to language, be forced under the appellation of offences againft property. Property, confidered with refpeet to the proprietor, implies invariably a benefit, and nothing elfe: whatever obligations or burthens may, by accident, ftand annexed to it, yet in itfelf it can never be otherwife than beneficial. On the part of the proprietor, it is created not by any commands that are laid on him, but by his being left free to do with fuch or fuch an article as he likes. The obligations it is created by, are in every inftance laid upon other people. On the other hand, as to conditions, there are feveral which are of a mixt nature, importing as well a burthen to him who ftands invefted with them as a benefit: which indeed is the cafe with thofe conditions which we hear moft of under that name, and which make the greateft figure. There are even conditions which import nothing but burthen, without any fpark of benefit. Accordingly, when between two parties there is fuch a relation, that one of them ftands in the place of an object of property with refpest to the other: the word property is applied only on one fide; but the word condition is applied alike to both : it is but one of them that is faid on that account to be poffeffed of a property: but both of them are alike fpoken of as being poffeffed of or being invefted with a cundition: it is the mafter alone that is confidered as poffefing a property, of which the fervant, in virtue of the fervices he is bound to render, is the object: Lut the fervant, not lefs than the mafter, is fpoken of as poffeffing or being invefted with a condition.

The cafe is, that if a man's condition is ever fpoken of as conftituting an article of his property, it is in the fame loofe and indefinite fenfe of the word in which almoft every other offence that could be imagined might be reckoned into the lift of offences againft property. If the language indeed were in every inftance, in which it made ufe of the phrafe, object of property, perfpicuous enough to point out under that appellation the material and really-exiftent body, the

$$
\mathrm{Gg} 2 \quad \text { perfon }
$$


INTROD. perfon or the tbing in which thofe acts terminate, by the performance CHAP.XVI. of which the property is faid to be enjoyed; if, in fhort, in the import given to the phrafe object of property, it made no other ufe of it than the putting it to fignify what is now called a corporeal objezt, this difficulty and this confufion would not have occurred. But the import of the phrafe object of property, and in confequence the import of the word property, has been made to take a much wider range. In almoft every cafe in which the law does any thing for a man's benefit or advantage, men are apt to fpeak of it, on fome occafion or other, as conferring on him a fort of property. At the fame time, for one reafon or other, it has in feveral cafes been not practicable, or not agreeable, to bring to view, under the appellation of the object of bis property, the thing in which the acts, by the performance of which the property is faid to be enjoyed, have their termination, or the perfon in whom they have their commencement. Yet fomething which could be fpoken of under that appellation, was abfolutely requifite". The expedient then has been to create, as it were, on every occafion, an ideal being, and to affign to a man this ideal being for the object of his property: and thefe are the fort of objects to which men of fcience,

"It is to be obferved, that in common fpeech, in the phrafe the object of a man's property, the words the object of are commonly left out; and by an ellipfis, which, violent as it is, is now become more familiar than the phrafe at length, they have made that part of it which confifts of the words a man's property, perform the office of the whole. In fome cafes then it was only on a part of the object that the acts in queltion might be performed: and to fay, on this account, that the object was a man's property, was as much as to intimate that they might be performed on any part. In other cafes it was only certain particular acts that might be exercifed on the object : and to fay of the object that it was his property, was as much as to intimate that any acts whatever might be exercifed on it. Sometimes the acts in queftion were not to be exercifed but at a future time, nor then, perhaps, but in the cale of the happening of a particular event, of which the happening was uncertain: and to fay of an object that it was his property, was as much as to intimate that the acts in queftion might be exercifed on it at any time. Sometimes the object on which the acts in queltion were to have their termination, or their commencement, was a human creature : and to fpeak of one human creature as being the property of another, is what would thock the ear every where but where flavery is eftailithed, and even there, when applied to perfons in any other condition than that of naves. Among the firft 
in taking a view of the operations of the law in this behalf, came, in INTROD. procefs of time, to give the name of incorporeal. Now of thefe in- Chap. XVI. corporeal objects of property the variety is prodigious. Fictitious entities of this kind have been fabricated almoft out of every thing; not conditions only (that of a truftee included) but even reputation have been of the number. Even liberty has been confidered in this fame point of view: and though on fo many occafions it is contrafted with property, yet on other occafions, being reckoned into the catalogue of poffeffions, it feems to have been confidered as a branch of property. Some of there applications of the words property, object of property, (the laft, for inftance) are looked upon, indeed, as more figurative, and lefs proper than the reft: but fince the truth is, that where the immediate object is incorporeal, they are all of them improper, it is farce practicable any where to draw the line.

Notwithftanding all this latitude, yet, among the relations in virtue of which you are faid to be poffeffed of a condition, there is one at leaft which can fcarcely, by the moft forced conftruction, be faid to render any other man, or any other thing, the object of your property. This is the right of perfevering in a certain courfe of action; for inftance, in the exercifing of a certain trade. Now to confer on you this right, in a certain degree at leaft, the law has nothing more to do than barely to abftain from forbidding you to exercife it. Were it to go farther, and, for the fake of enabling you to exercife your trade to the greater advantage, prohibit others from exercifing the like; then, indeed, perfons might be found, who in a certain fenfe, and by ar conftruction rather forced than otherwife, might be fpoken of as being the objects of your property: viz. by being made to render you that fort of negative fervice which confints in the forbearing to do thofe

Romans, indeed, the wife herfelf was the property of her hufband; the child, of his father; the fervant, of his mafter. In the civilized nations of modern times, the two firft kinds of property are altogether at an end: and the laft, unhappily not yet at an end, but however verging, it is to be hoped, towards extinction. The huband's property is now the company " of his wife; the father's, the guardianfhip and fervice of his child; the mafter's, the fervice of his fervant. 
INTROD. acts which would leffen the profits of your trade. But the ordinary CHAP. XVI. right of exercifing any fuch trade or profeffion, as is not the object of a monopoly, imports no fuch thing: and yet, by poffeffing this right, a man is faid to poffefs a condition: and by forfeiting it, to forfeit his condition.

After all, it will be feen, that there muft be cafes in which, according to the ufage of language, the fame offence may, with more or lefs appearance of propriety, be referred to the head of offences againft condition, or that of offences againft property indifferently. In fuch cafes the following rule may ferve for drawing the line. Wherever, in virtue of your poffefling a property, or being the object of a property poffeffed by another, you are characterifed, according to the ufage of language, by a particular name, fuch as mafter, fervant, hußband, wife, fteward, agent, attorney, or the like, there the word condition may be employed in exclufion of the word property: and an offence in which, in virtue of your bearing fuch relation, you are concerned, either in the capacity of an offender, or in that of a party injured, may be referred to the head of offences againft condition, and not to that of offences againt property. To give an example: Being bound, in the capacity of land-fteward to a certain perfon, to overfee the repairing of a certain bridge, you forbear to do fo: in this cafe, as the fervices you are bound to render are of the number of thofe which give occafion to the party, from whom they are due, to be fpoken of under a certain generical name, viz. that of land-fteward, the offence of with-holding them may be referred to the clafs of offences againft condition. But fuppofe that, without being engaged in that general and mifcellaneous courfe of fervice, which with reference to a particular perfon would denominate you his land-fteward, you were bound, whether by ufage or by contract, to render him that fingle fort of fervice which confifts in the providing, by yourfelf or by others, for the repairing of that bridge: in this cafe, as there is not any fuch current denomination to which, in virtue of your being bound to render this fervice, you ftand aggregated (for that of architect, mafon, or the like, is not here in queftion) the offence you commit by with-holding fuch fervice cannot with propriety be referred 
to the clafs of offences againft condition: it can only therefore be re- INTROD. ferred to the clafs of offences againft property.

By way of further diftinction, it may be remarked, that where a man, in virtue of his being bound to render, or of others being bound to render him, certain fervices, is fpoken of as poffeffing a condition, the affemblage of fervices is generally fo confiderable, in point of duration, as to conftitute a courfe of confiderable length, fo as on a variety of occafions to come to be varied and repeated: and in moft cafes, when the condition is not of a domeftic nature, fometimes for the benefit of one perfon, fometimes for that of another. Services which come to be rendered to a particular perfon on a particular occafion, efpecially if they be of thort duration, have feldom the effect of occafioning either party to be fpoken of as being invefted with a condition. The particular occafional fervices which one man may come, by contract or otherwife, to be bound to render to another, are innumerably various: but the number of conditions which have names may be counted, and are, comparatively, but few.

If after all, notwithftanding the rule here given for feparating conditions from articles of property, any object fhould prefent itfelf which fhould appear to be referable, with equal propriety, to either head, the inconvenience would not be material; fince in fuch cafes, as will be feen a little farther on*, whichever appellation were adopted, the lift of the offences, to which the object ftands expofed, would be fubftantially the fame.

Thefe difficulties being cleared up, we now proceed to exhibit an analytical view of the feveral poffible offences againft truft.

\section{XXVII.}

Offences againft truft may be diftinguined, in the firft place, into fuch as concern the exiftence of the truft in the hands of fuch or fuch a perfon, and fuch as concern the exercife of the functions that belong to it ${ }^{x}$. Firft then, with regard to fuch as relate to its exiftence. An

$x$ We thall have occafion, a little farther on, to fpeak of the perfon in whofe hands the truft exifts, under the defcription of the perfon who poffeffes, or is in poffeffion of it, and thence of the poffeffion of the truit abstracted from the confideration of the 
INTROD. Offence of this defcription, like one of any other defcription, if an Chap.XVI. offence it ought to be, muft to fome perfon or other import a prejudice. This prejudice may be diftinguifhed into two branches: 1. That which may fall on fuch perfons as are or fhould be invefted with the truft: 2. That which may fall on the perfons for whofe fake it is or fhould be inftituted, or on other perfons at large. To begin with the former of thefe branches. Let any trut be conceived. The confequences which it is in the nature of it to be productive of to the poffeffor, mut, in as far as they are material*, be either of an advantageous or of a difadvantageous nature: in as far as they are advantageous, the truft may be confidered as a benefit or privilege: in as far

poffeffor. However different the expreffion, the import is in both cafes the fame. So irregular and imperfekt is the ftructure of language on this head, that no one phrafe can be made to fuit the idea on all the occafions on which it is requifite it thould be brought to view: the phrafe mutt be continually thifted, or new modified: fo likes wife in regard to conditions, and in regard to property. The being invefted with, or poffeffing a condition; the being in poffeffion of an article of property, that is, if the object of the property be corporeal; the having a legal title (defeafible or indefeafible) to the phyfical poffeffion of it, anfwers to the being in poffeffion of a truft, or the being the perfon in whofe hands a truft exifts. In like manner, to the exercife of the functions belonging to a truft, or to a condition, correfponds the enjoyment of an article of property; that is, if the object of it be corporeal, the occupation. Thefe verbal difcuffions are equally tedious and indifpenfable. Striving to cut a new road through the wilds of jurifprudence, I find myfelf continually diftreffed, for want of tools that are fit to work with. To frame a compleat fet of new ones is impoffible. All that can be done is, to make here and there a new one in cafes of abfolute necefity, and for the reft, to patch up from time to time the imperfections of the old.

As to the bipartition which this paragraph fets out with, it muft be acknowledged not to be of the nature of thofe which to a firft glance affurd a fort of intuitive proof of their being exhaufive. There is not that marked connection and oppofition between the terms of it, which fubfifts between contradiftory terms and between terms that have the fame common genus. I imagine, however, that upon examination it would be found to be exhauftive notwithltanding: and that it might even be demonftrated fo to be. But the demonftration would lead us too far out of the ordinary krack of language.

* See chap. vii. [Actions] iii. 
as they are difadvantageous, it may be confidered as a burthen ". To INTROD. confider it then upon the footing of a benefit. The truft either is of CHap.XVI. the number of thofe which ought by law to fubfift ${ }^{z}$; that is, which the

y. If advantageous, it will naturally be on account of the porvers or rights that are annexed to the truft: if difadvantageous, on account of the duties.

z It may feem a fort of anachronifm to fpeak on the prefent occafion of a truff, condition, or other poffeffion, as one of which it may happen that a man ought or ought not to have had poffeffion given him by the law. For the plan here fet out upon is to give fuch a view all along of the laws that are propofed, as Thall be taken from the reafons which there are for making them : the reafon then it would feem thould fubfift before the law : not the law before the reafon. Nor is this to be denied : for, unqueftionably, upon the principle of utility, it may be faid with equal truth of thofe operations by which a truft, or any other articie of property, is inftituted, as of any other operations of the law, that it never can be expedient they fhould be performed, unlefs fome reafon for performing them, deduced from that prin. ciple, can be afigned. To give property to one man, you muft impofe obligation on another: you muft oblige him to do fomething which he may have a mind not to do, or to abftain from doing fomething which he may have a mind to do: in a word, you muft in fome way or other expofe him to inconvenience. Every fuch law, therefore, mut at any rate be mifclievous in the firft inftance: and if no good effects can be produced to fet againt the bad, it muft be mifchicvous upon the whole. Some reafons, therefore, in this cafe, as in every other, there ought to be. The truth is, that in the cafe before us, the reafons are of too various and complicated a nature to be brought to view in an analytical outline like the prefent. Where the offence is of the number of thofe by which perfon or reputation are affected, the reafons for prohibiting it lie on the furface, and apply to every man alike. But property, before it can be offended againft, muft be created, and at the infant of its creation diftributed, as it were, into parcels of different forts and fizes, which require to be affigned, fome to one man and fome to another, for reafons, of which many lie a little out of fight, and which being different in different cafes, would take up more room than could confiftently be allotted to them here. For the prefent purpofe, it is fufficient if it appear, that for the carrying on of the feveral purpofes of life, there are trufts, and conditions, and other articles of property, which muft be poffeffed by fomebody: and that it is not every article that can, nor every article that ought, to be poffeffed by every body. What articles ought to be created, and to what perfons, and in what cafes they ought to be refpectively affigned, are queftions which cannot be fettled here. Nor is there any reafon for wining that they could, fince the fettling them one way or another is what would make no difference in the nature of any offence whereby any party may be expofed, on the occafion of any fuch infitution, to futtain a detriment.

VOL. I.

$\mathrm{Hh}$

leginator 
INTROD. leginator meant hould be eftablifhed; or is not. If it is, the pofferChap. XVI. fion which at any time you may be deprived of, with refpect to it, muft at that time be either prefent or to come: if to come (in which cafe it may be regarded either as certain or as contingent) the inveftitive event, or event from whence your poffeffion of it hould have taken its commencement, was either an event in the production of which the will of the offender hould have been inftrumental, or any other event at large: in the former cafe, the offence may be termed sorongful non-inveftment of truft: in the latter cafe, wrongful interception of truft. If at the time of the offence whereby you are deprived of it, you were already in poffeffion of it, the offence may be ftiled wrongful diveftment of truft. In any of thefe cafes, the effect of the offence is either to put fomebody elfe into the truft, or not: if not, it is \#rongful diveftment, wrongful interception, or wrongful diveftment, and nothing more: if it be, the perfon put in poffeffion is either the wrong-doer himfelf, in which cafe it may be ftiled ufurpation of truft; or fome other perfon, in which cafe it may be ftiled wrongful inveftment, or attribution, of truft. If the truft in queftion is not of the number of thofe which ought to fubfift, it depends upon the manner in which one man deprives another of it, whether fuch deprivation thall or thall not be an offence: and accordingly, whether non-inveftment, interception, or diveftment, thall or thall not be wrongful. But the putting any body into it muft at any rate be an offence: and this offence may be either ufurpation or wrongful invertment, as before.

In the next place, to confider it upon the footing of a burthen. In this point of view, if no other intereft than that of the perfons liable

a In the former cafe it may be obferved, the aet is of the negative kind: in the latter, it will commonly be of the pofitive kind.

As to the expreffion non-inveftment of $t r a j$, I am fenfible that it is not perfectly confonant to the idiom of the language: the ufage is to fpeak of a perfon as being invefted (that is cloatbed) with a truft, not of a trutt as of a thing that is itfelf inveffed, or put on. The phrafe at length would be, the non-invefment of a perfon will a truft: but this phrafe is by much too long-winded to anfiver the purpofe of an appellative. I faw, therefore, no other refource than to venture upon the ellipfis here employed. The antient lawyers, in the confruetion of their appellatives, have indulged themfelves in much harfher ellipfifes without fcruple. See above, xxv. note. It is already the ufage to fpeak of a truft as a thing that vefts, and as a thing that may be divefted. 
to be invefted with it were confidered, it is what ought not, upon the principle of utility, to fubfift: if it ought, it can only be for the fake of the perfons in whofe favour it is eftablifhed. If then it ought not on any account to fubfift, neither non-inveftment, interception, nor diveftment, can be wrongful with relation to the perfons firft-mentioned, whatever they may be on any other account, in refpect of the manner in which they happen to be performed: for ufurpation, though not likely to be committed, there is the fame room as before: fo likewife is there for wrongful invertment; which, in as far as the truft is confidered as a burthen, may be ftiled wrongful impofition of truft. If the truft, being ftill of the burthenfome kind, is of the number of thofe which ought to fubfift, any offence that can be committed, with relation to the exiftence of it, muft confift either in caufing a perion to be in poffeffion of it, who ought not to be, or in caufing a perfon not to be in poffeffion of it who ought to be: in the former cafe, it muft be either ufurpation or wrongful diveftment, as before: in the latter cafe, the perion who is caufed to be not in poffefion, is either the wrong doer himfelf, or fome other: if the wrong doer himfelf, either at the time of the offence he was in poffeffion of it, or he was not: if he was, it may be termed wrongful abdication of truft; if not, wrong ful detrectation ${ }^{b}$ : if the perfon, whom the offence caufes not to be in the truft, is any other perfon, the offence muft be either wrongful diveftment, wrongful non-inveftment, or wrongful interception, as before: in any of which cafes, to confider the truft in the light of a burthen, it might alfo be ftiled wrongful exemption from truft.

Laftly, with regard to the prejudice which the perfons for whofe benefit the truft is inftituted, or any other perfons whofe interefts may come to be affected by its exifting or not exifting in fuch or fuch hands, are liable to fuftain. Upon examination it will appear, that by every fort of offence whereby the perfons who are or thould be in poffeffion of it are liable, in that refpect, to fuftain a prejudice, the perfons now in queftion are alfo liable to fuftain a prejudice. The prejudice,

b [Detrectation.] I do not find that this word has yet been received into the Englin language. In the Latin, however, it is very expreffive, and is ufed in a fenfe exactly fuitable to the fenfe here given to it. Militiam detrectare, to endeavour to avoid ferving in the army, is a phrafe not unfrequently met with in the Roman writers. 
INTROD. in this cafe, is evidently of a very different nature from what it was ChAP.XVI. of in the other: but the fame general names will be applicable in this cafe as in that. If the beneficiaries, or perfons whofe interefts are at ftake upon the exercife of the truft, or any of them, are liable to fuftain a prejudice, refulting from the quality of the perfon by whom it may be filled, fuch prejudice muft refult from the one or the other of two caufes: I. From a perfon's having the poffeffion of it who ought not to have it: or 2. From a perfon's not having it who ought: whether it be a benefit or burthen to the poffeffor, is a circumftance that to this purpofe makes no difference. In the firft of thefe cafes the offences from which the prejudice takes its rife are thofe of ufurpation of truft, wrongful attribution of truft, and wrongful impofition of truft: in the latter, wrongful non-inveftment of truft, wrongful interception of truft, wrongful diveftment of truft, wrongful abdication of truft, and wrongful detrectation of truft.

So much for the offences which concern the exiftence or poffeffion of a truft: thofe which concern the exercife of the functions that belong to it may be thus conceived. You are in poffeffion of a trunt: the time then for your acting in it mult, on any given occafion, (neglecting, for fimplicity's fake, the then prefent inftant) be either paft or yet to come. If paft, your conduct on that occafion muft have been either conformable to the purpoles for which the truft was inftituted, or unconformable: if conformable, there has been no mifchief in the cafe : if unconformable, the fault has been either in yourfelf alone, or in fome other perfon, or in both: in as far as it has lain in yourfelf, it has confifted either in your not doing fomething which you ought to do, in which cafe it may be ftiled negative breacb of truft; or in your doing fomething which you ought not to do: if in the doing fomething which you ought not to do, the party to whom the prejudice has accrued is either the fame for whole benefit the truft was inftituted, or fome other party at large: in the former of thefe cafes, the offence may be ftiled poffive breach of truft; in the other, abufe of truft $\mathrm{c}$.

- What is here meant by abufe of truft, is the exercife of a power ufurped over Arangers, under favour of the powers properly belonging to the truft. The diftinction 
In as far as the fault lies in another perfon, the offence on his part INTROD. may be ftiled difturbance of truft. Suppofing the time for your acting CHAP.XVI. in the truft to be yet to come, the effect of any act which tends to render your conduct unconformable to the purpofes of the truft, may be either to render it actually and eventually unconformable, or to produce a chance of its being fo. In the former of thefe cafes, it can do no otherwife than take one or other of the fhapes that have juft been mentioned. In the latter cafe, the blame mutt lie either in yourfelf alone, or in fome other perfon, or in both together, as before. If in another perfon, the acts whereby he may tend to render your conduct unconformable, muft be exercifed either on yourfelf, or on other objects at large. If exercifed on yourfelf, the influence they poffefs mut either be fuch as operates immediately on your body, or fuch as operates immediately on your mind. In the latter cafe, again, the tendency of them muft be to deprive you either of the knowledge, or of the power, or of the inclination *, which would be neceffary to your maintaining fuch a conduct as thall be conformable to the purpofes in queftion. If they be fuch, of which the tendency is to deprive you of the inclination in queftion, it muft be by applying to your will the force of fome feducing motive t. Laftly, This motive mutt be either of the coercive, or of the alluring kind; in other words, it mult prefent itfelf either in the thape of a mifchief or of an advantage. Now in none

between what is here meant by breach of truft, and what is here meant by abufe of truft, is not very fteadily obferved in common fpeech: and in regard to public trufts, it will even in many cafes be imperceptible. The two offences are, however, in themfelves perfectly diftinct: fince the perfons, by whom the prejudice is fuffered, are in many cafes altogether different. It may be noticed, perhaps, for a moment, as an omifion, that of abufe of truft, no more than one fpecies is here mentioned; viz. that which correfponds to pofitive breach of truft: none being mentioned as correfponding to negative breach of truft. The reafon of this diftinction will prefently appear. In favour of the parties for whofe benefit the trutt was created, the truftee is bound to ant; and therefore merely by his doing nothing they may receive a prejudice: but in favour of other perfons at large he is not bound to act: and therefore it is only from fome pofitive act on his part that any prejudice can enfue to them.

* See infra, liv, note; and ch, xviii. [Indirect Legi $\AA_{a t i o n .]}$

+ See ch. xi. [Difpofitions] xxix. 
INTROD. of all the caies that have been mentioned, except the laft, does the CAAP. XVI. offence receive any new denomination; according to the event, it is either a difturbance of truft or an abortive attempt to be guilty of that offence. In this laft it is termed bribery; and it is that particular fpecies of it which may be termed active bribery, or bribe-giving. In this cafe, to confider the matter on your part, either you accept of the bribe, or you do not: if not, and you do not afterwards commit, or go about to commit, either a breach or an abufe of truft, there is no offence, on your part, in the cafe: if you do accept it, whether you eventually do or do not commit the breach or the abufe which it is the bribegiver's intention you hould commit, you at any rate commit an offence which is alfo termed bribery: and which, for diftinction' fake, may be termed paffive bribery, or bribe-taking '. As 'to any farther diftinctions, they will depend upon the nature of the particular fort of truft in queftion, and therefore belong not to the prefent place. And thus we have thirteen fub-divifions of offences againit truft: viz. 1. Wrongful non-inveftment of truft. 2. Wrongful interception of truft. 3. Wrongful diveftment of truft. 4. Ufurpation of truit. 5. Wrongful inveitment or attribution of truft. 6. Wrongful abdication of truft. 7. Wrongful detrectation of truft. 8. Wrongful impofition of truft. 9. Negative breach of truft. 10. Pofitive breach of truft. II. Abufe of truft. 12. Difturbance of truft. 13. Bribery.

\section{XXVIII.}

Prodigality From what has been faid, it appears that there cannot be any other in truftees difmiffed to Clafs 3 . offences, on the part of a truftee, by which a beneficiary can receive on any particular occafion any affignable fpecific prejudice. One fort of acts, however, there are by which a truftee may be put in fome

d To bribe a truftee, as fuch, is in fact neither more nor lefs than to fuborn him to be guilty of a breach or an abufe of truft. Now fubornation is of the number of thofe acceffory offences which every principal offence, one as well as another, is liable to be attended with. See infra, xxxi. note: and B. I. tit. [Acceffory offences.] This particular fpecies of fubornation however, being one that, befides its having a fpecific name framed to exprefs $i t$, is apt to engage a peculiar fhare of attention, and to prefent itfelf to view in company with other offences againft trul, it would have feemed an omifion not to have included it in that catalogue. 
danger of receiving a prejudice, although neither the nature of the INTROD. prejudice, nor the occafion on which he is in danger of receiving it, Crap. XVI. fhould be affignable. Thefe can be no other than fuch acts, whatever they may be, as difpofe the truftee to be acted upon by a given bribe with greater effect than any with which he could otherwife be acted upon: or in other words, which place him in fuch circumftances as have a tendency to encreafe the quanturn of his fenfibility to the action of any motive of the fort in queftion*. Of thefe acts, there feem to be no others, that will admit of a defcription applicable to all places and times alike, than acts of prodigality on the part of the truftee. But in acts of this nature the prejudice to the beneficiary is contingent only and unliquidated; while the prejudice to the truftee himfelf is certain and liquidated. If therefore on any occafion it fhould be found advifeable to treat it on the footing of an offence, it will find its place more naturally in the clafs of felfregarding ones.

\section{XXIX.}

As to the fub-divifions of offences againft truft, thefe are perfectly analogous to thore of offences by falfhood. The truft may be private, femi-public, or public: it may concern property, perfon, reputation, or condition; or any two or more of thofe articles at a time: as will be more particularly explained in another place. Here too the offence, in running over the ground occupied by the three prior claffes, will in fome inftances change its name, while in others it will not.

\section{$\mathrm{XXX}$.}

Laftly, If it be anked, What fort of relation there fubfifts between Connection falfhcods on one hand, and offences concerning truft on the other between ofhand; the anfwer is, they are altogether difparate. Falhood is a falthood and circumftance that may enter into the compofion of any fort of offence, offences thofe concerning truft, as well as any other: in fome as an accidental, in others as an effential inftrument. Breach or abufe of truft are circumftances which, in the character of accidental concomitants, may 
INTROD. enter into the compofition of any other offences (thofe againt falhood

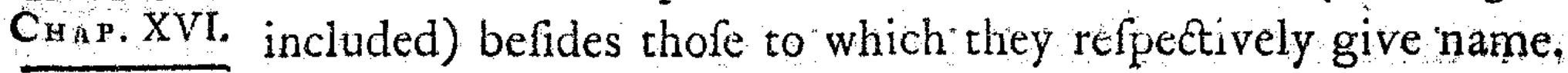

\section{Genera of class I.}

XXXI.

Analyfis into Returning now to clafs the firf, let us purfue the diftribution a ftep genera pur- farther, and branch out the feveral divifions of that clafs, as above ex-

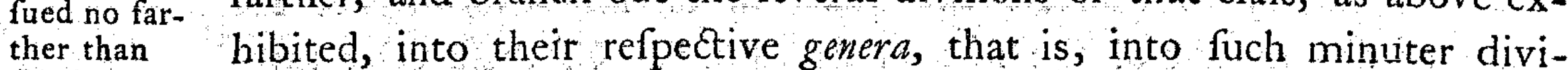
Clafs I. frons as are capable of being characterifed by denominations of which a great part are already current among the people e. In this place the analyfis muft ftop. To apply it in the fame regular form to any of the other claffes feems fcarcely practicable: to femi-public, as alfo to public offences, on account of the interference of local circumftances : to felf-regarding ones, on account of the neceffity it would create of deciding prematurely upon points which may appear liable to controverfy : to offences by falfhood, and offences againft truft, on account of the dependence there is between this clafs and the three former. What remains to be done in this way, with reference to thefe four claffes, will require difcuffion, and will therefore be introduced with more propriety in the body of the work, than in a preliminary part, of which the bufinefs is only to draw outlines.

\section{XXXII.}

Offences againf an individual may be fim. ple in their effects, or complex,
An act, by which the happinefs of an individual is difturbed, is either fimple in its effects or complex. It may be ftiled fimple in its effects, when it affeets him in one only of the articles or points in which his intereft, as we have feen, is liable to be affected: complex, when it affeets him in feveral of thofe points at once. Such as are fimple in their effeets mult of courfe be firft confidered.

c In the enumeration of thefe genera, it is all along to be obferved, that offences of an acceflory nature are not mentioned, unlefs it be here and there where they have obtained current names which feemed too much in vogue to be omitted. Acceffory offences are thofe which, without being the very acts from which the mifchief in queftion takes its immediate rife, are, in the way of caufality, connected with thofe acts. See ch, vii. [Actions] xxiv, and B. I. tit. [Acceffory offences.]

XXXIII. In 
XXXIII.

In a fimple way, that is in one way at a time, a man's happinefs is liable to be difturbed either I. By actions referring to his own perfon itfelf; or 2. By actions referring to fuch external objects on which his happinefs is more or lefs dependent. As to his own perfon, it may be confidered as compored of two different parts, his body and his mind. Acts which exert a pernicious influence on his perfon, whether it be on the corporeal or on the mental part of it, will operate thereon either immediately, and without affecting his will, or mediately, through the intervention of that faculty: viz. by means of the influence which they caufe his will to exercife over his body. If with the intervention of his will, it muft be by mental coercion: that is, by caufing him to will to maintain, and thence actually to maintain, a certain conduct which it is difagreeable, or in any other way pernicious, to him to maintain. This conduct may either be : pofitive or negative $*$ when pofitive, the coercion is ftiled compulfion or conftraint: when negative, reftraint. Now the way in which the coercion is difagreeable to him, may be by producing either pain of body, or only pain of mind. If pain of body is produced by it, the offence will come as well under this as under other denominations, which we thall come to prefently. Moreover, the conduct which a man, by means of the coercion, is forced to maintain, will be determined either fpecifically and originally, by the determination of the particular acts themfelves which he is forced to perform or to abitain from, or generally and incidentally, by means of his being forced to be or not to be in fuch or fuch a place. But if he is prevented from being in one place, he is confined thereby to another. For the whole furface of the earth, like the furface of any greater or leffer body, may be conceived to be divided into two, as well as into any other number of parts or fpots. If the fpot, then, which he is confined to be fmaller than the fpot which he is excluded from, his condition may be called confinement : if larger, banißment $\mathbf{s}$. Whether an

act,

Of thefe, and the feveral other leading expreffions which there is occafion to bring - Ch. vii. [Actions] viii.

Vor. I. 
INTROD, act, the effect of which is to exert a pernicious influence on the perfon CuAp. XVI. of him who fuffers by it, operates with or without the intervention of an act of his will, the mifchief it produces will either be mortal or not mortal. If not mortal, it will either be reparable, that is temporary; or irreparable, that is perpetual. If reparable, the mifchievous act may be termed a fimple corporal injury; if irreparable, an irreparable corporal injury. Laftly, a pain that a man experiences in his mind will either be a pain of actual fufferance, or a pain of apprebenfion. If a pain of apprehenfion, either the offender himfelf is reprefented as intending to bear a part in the production of it, or he is not. In the former cafe the offence may be ftiled menacement: in the latter cafe; as alfo where the pain is a pain of actual fufferance, a fimple mental injury. And thus we have nine genera or kinds of perfonal injuries; which, when ranged in the order moit commodious for examination, will ftand as follows; viz. 1. Simple corporal injuries. 2. Irreparable corporal injuries. 3. Simple injurious reftrainment. 4. Simple injurious compulfion ". 5. Wrongful confinement. 6. Wrongful banifhment.

to view in the remaining part of this analyfis, ample definitions will be found in the body of the work, conceived in terminis legis. To give particular references to thefe. definitions, would be incumbering the page to little purpofe.

h Injurious reftrainment at large, and injurious compulfion at large, are here ftiled: fimple, in order to diftinguifh them from confinement, banifhment, robbery, and extortion; all which are, in many cafes, but fo many modifications of one or other of the two firft-mentioned offences.

To conftitute an offence an act of fimple injurious reftrainment; or fimple injurious. compulfion, it is fufficient if the influence it exerts be, in the firf place, pernicious; in the next place, exerted on the perfon by the medium of the will : it is not neceffary. that that part of the perfon on which it is exerted be the part to which it is pernicious : it is not even neceffary that it thould immediately be pernicious to either of thefe. parts, though to one or other of them it muft be pernicious in the long-run, if it be pernicious at all. An act in which the body, for example, is concerned, may be very. difagreeable, and thereby pernicious to him who performs it, though neither difagreeable nor pernicious to his body: for inftance, to ftand or fit in public with a label on, sia back, or under any other circumftances of ignominy. 


\section{[D I V I S I O N] of offences.}

\section{Wrongful homicide. 8. Wrongful menacement ${ }^{\mathrm{i}}$ 9. Simple mental injuries $\mathrm{k}$.

It may be obferved, that wrongful menacement is included as well in fimple injurious reftrainment as in fimple injurious compulfion, except in the rare cafe where the motives by which one man is prevented by another from doing a thing that would have been materially to his advantage, or induced to do a thing that is materially to his prejudice, are of the alluring kind.

$k$ Although, for reafons that have been already. given (fupra xxxi.) no compleat catalogue, nor therefore any exhauftive view, of either femi-public or felf-regarding offences, can be exhibited in this chapter, it may be a fatisfaction, however, to the reader, to fee fome fort of lift of them, if it were only for the fake of having examples before his eyes. Such lifts cannot any where be placed to more advantage than under the heads of the feveral divifions of private extra-regarding offences, to which the femi; public and felf-regarding offences in queltion refpectively correfpond. Concerning the two latter, however, and the laft more particularly, it muft be underfood that all I mean by inferting them here, is to exhibit the mifchief, if any, which it is of the nature of them refpectively to produce, withont deciding upon the queftion, whether it would be worth while [See ch. xiii. Cafes unmeet] in every inftance, for the fake of combating that mifchief, to introduce the evil of punifhment. In the couffe of this detail, it will be obferved, that there are feveral heads of extra-regarding private offences, to which the correfpondent heads, either of femi-public or felf-regarding offences, or of both, are wanting. The reafons of thefe deficiencies will probably, in moft inftances, be evident enough upon the face of them. Left they mould not, they are however fpecified in the body of the work. They would take up too much room were they to be inferted here.

I. SEMI-PUBLIC OFreNCEs through calamity. Calamities, by which the perfons or properties of men, or both, are liable to be affected, feem to be as follows: 1. Peftilence or contagion. 2. Famine, and other kinds of fearcity. 3. Mifchiefs producible by perfons deficient in point of underftanding, fuch as infants, idiots, and maniacs, for want of their being properly taken care of. 4. Mirchief producible by the ravages of noxious animals, fuch as beafts of prey, locufs, \&c. \&rc. 5. Collapfion, or fall of large mafies of folid matter, fuch as decayed buildings, or rocks, or maftes of fnow. 6. Inundation or fubmerfion. 7. Tempeft. 8. Blight. 9. Conflagration. 10. Explofion. In as far as a man may contribute, by any imprudent act of his, to give birth to any of the above calamities, fuch act may be an offence. In as far as a man may fail to do what is incumbent on him to do towards preventing them, fuch failure may be an offence.

II. SEMI-PUBLIC OFFENCES of mere delinquency. A whole neighbourhood may be made to fuffer, I. Simple corporal injuries: in other words, they may be made to fuffer in 
ccxliv

INTROD.

Chap. XVI.

Offences againft reputation.
[D I V I S I O N] of offences.:

\section{XXXIV.}

We come now to offences againft reputation merely. Thefe require: but few diftinctions. In point of reputation there is but one way of fuffering, which is by lofing a portion of the good-will of others. Now, in refpect of the good-will which others bear you, you may be a lofer in either of two ways: $x$. By the manner in which you are thought to behave yourfelf; and 2. By the manner in which otbers behave, or are thought to behave, towards you. To caufe people to think that you yourfelf have fo behaved, as to have been guilty of any of thofe acts which caufe a man to poffefs lefs than he did before of the good-will of the community, is what may be ftiled. defamation. But fuch is the conftitution of human nature, and fuch the force of prejudice, that a man, merely by maniferting his own want of good-will towards you, though ever fo unjuft in itfelf, and ever fo

point of health, by offenfive or dangerous trades or manufactures: by felling or falfely. puffing off unwholefome medicines or provifions : by poifoning or drying up of fprings, deftroying of aqueducts, deftroying woods, walls, or other fences againit wind and rain : by any kinds of artificial fcarcity; or by any other calamities intentionally produced. 2 and 3 . Simple injurious reftrainment, and fimple injurious compulfion : for inftance, by obliging a whole neighbourhood, by dint of threatening hand-bills or threatening difcourfes publicly delivered, to join or forbear to join, in illuminations, acclamations, outcries, invectives, fubfcriptions, undertakings, proceffions, or any other mode of exprefing joy or grief, difpleafure or approbation; or, in fhort, in any other courfe of conduct whatfoever. 4 and 5. Confinement and banifhment: by the. fpoiling of roads, bridges, or ferry-boats : by deftroying or unwarrantably pre-occupying public carriages, or houfes of accommodation. 6. By menacement: as by incendiary letters, and tumultuous affemblies : by news-papers or hand-bills, denouncing vengeance againft perfons of particular denominations: for example, againft Jews, Catholics, Proteftants, Scotchmen, Gafcons, Catalonians, \&c. 7. Simple mental injuries: as by diftrefsful, terrifying, obfcene, or irreligious exhibitions : fuch as expofure of fores by beggars, expofure of dead bodies, exhibitions or reports of counterfeit witchcrafts or apparitions, exhibition of obfcene or blafphemous prints: obfcene or blafphemous difcourfes held in public: fpreading falfe news of public defeats in battle, or of other misfortunes.

III. Self-regarding offences againft perfon. 1. Fafting, Abfinence from venery, felf-flagellation, felf-mutilation, and other felf-denying and felf-tormenting practices. 2. Gluttony, drunkennefs, exceffive venery, and other fpecies of intemperance. 3. Suicide.

unlawfully 
unlawfully expreffed; may in a manner force others to withdraw from INTROD: you a part of theirs. When he does this by words, or by fuch actions CHAP. XVI: as have no other effect than in as far as they ftand in the place of words, the offence may be ftiled vilification. When it is done by fuch actions as, befides their having this effect, are injuries to the perfon; the offence may be ftiled a perfonal infult: if it has got the length of reaching the body, a corporal infult: if it ftopt hort before it reached that length, it may be ftiled infulting menacement. And thus we have two genera or kinds of offences againft reputation merely; to wit; 1. Defamation: and, 2. Vilification'. As to corporal infults, and infulting menacement, they belong to the compound title of offences againft perfon and reputation both together.

XXXV.

If the property of one man fuffers by the delinquency of another; fuch property either was in truft with the offender, or it was not: if it was in truft, the offence is a breach of truft, and, of whatever nature it may be in other refpects, may be ftiled difipation in breach of truft, or difipation of property in truft. This is a particular cafe: the oppofite one is the more common: in fuch cafe the feveral ways in which property may, by poffibility, become the object of an offence, may be thus conceived: Offences againft property, of whatever kind it be, may be diftinguifhed; as hath been already intimated *, into fuch as concern the legal poffeffion of it or right to it, and fuch as concern only the enjoyment of it, or, what is the fame thing, the exercife of that right. Under the former of thefe heads come, as hath been already intimated $t$, the feveral offences of wrongful non-inveftment, wrongful interception, wrongful diveftment; ufurpation, and wrongful attribution. When in the commiffion of any of thefe offences a falfhood has ferved as an inftrument, and that, as it is commonly called, a wilful, or as it might more properly be termed, an advifed $\ddagger$ one, the epithet fraudulent may be prefixed to the name of the offence, or fubftituted in the room of

1. I. SBMI-PUBLIC OFFENCES. 1. Calumniation and vilification of particular deno. minations of perfons; fuch as Jews, Catholics, \&c.

II, SELF-REGARDING OFPENCES. I. Incontinence in females. 2. Incelt.

- Supra, xxvii.

t Ibid. $\ddagger$ See ch. ix. [Confcioufnefs] ii. 
INTROD. the word wrongful. The circumftance of fraudulency then may ferve to CHar. XVI. characterife a particular fpecies, comprifable under each of thofe generic heads: in like manner the circumftance of force, of which more a little farther on, may ferve to characterife another. With refpect to wrongful interception in particular, the inveftitive event by which the title to the thing in queftion thould have accrued to you, and for want of which fuch title is, through the delinquency of the offender, as it were, intercepted, is either an act of his own, expreffing it as his will, that you thould be confidered by the law as the perfon who is legally in poffeffion of it, or it is any other event at large: in the former cafe, if the thing, of which you fhould have been put into poffeffion, is a fum of money to a certain amount, the offence is that which has received the name of infolvency; which branch of delinquency, in confideration of the importance and extent of it, may be treated on the footing of a diftinct genus of itfelf ${ }^{m}$.

Next, with regard to fuch of the offences againft property as con-

cern

Payment, what. m The light in which the offence of infolvency is here exhibited, may perhaps at firft confideration be apt to appear not only novel but improper. It may naturally enough appear, that when a man owes you a fum of money, for inftance, the right to the money is your's already, and that what he with-holds from you by not paying you, is not the legal title to it, poffeffion of it, or power over it, but the phyfical poffeffion of it; or power over it, only. But upon a more accurate examination this will be found not to be the cafe. What is meant by payment, is always an act of inveftitive power, as above explained; an expreffion of an act of the will, and not a phyfical act : it is an aet exercifed witb relation indeed to the thing faid to be paid, but not in a phyfical fenfe exercifed upon it. A man who owes you ten pounds, takes up a handful of filver to that amount, and lays it down on a table at which you are fitting. If then by words, or geftures, or any means whatever, addreffing himfelf to you, he intimates it to be his will that you thould take up the money, and do with it as you pleafe, he is faid to have paid you : but if the cafe was, that he laid it down not for that purpofe, but for fome other, for inftance, to count it and examine it, meaning to take it up again himfelf, or leave it for fomebody elfe, he has not paid you: yet the phyfical acts, exercifed upon the pieces of money in queftion, are in both cafes the fame. Till he does exprefs a will to that purport, what you have is not, properly fpeaking, the legal poffeffion of the money, or a right to the money, but only a right to have him, or in his default perhaps a minifter of juftice, compelled to render you that fort of fervice, by the rendering of which he is faid to pay you : that is, to exprefs fuch will as abovementioned, 
cerr only the enjoyment of the objeet in queftion. This object muft be either a fervice, or fet of fervices *, which fhould have been rendered by fome perfon, or elfe an article belonging to the clafs of things. In the former cafe, the offence may be tiled wrongful witb-bolding of fervices ${ }^{n}$. In the latter cafe it may admit of farther modifications, which may be thus conceived: When any object which you have had the phyfical occupation or enjoyment of, ceafes in any degree, in confequence of the act of another man, and without any change made in fo much of that power as depends upon the intrinfic phyfical condition of your perfon, to be fubject to that power; this ceffation is owing either to a change in the intrinfic condition of the thing itfelf, or in its exterior fituation with refpect to you; that is, to its being fituated out

mentioned, with regard to fome corporeal article or other of a certain fpecies, and of value equal to the amount of what he owes you : or, in other words, to exercife in your favour an act of inveftitive power with relation to fome fuch article.

True it is, that in certain cafes a man may perhaps not be deemed, according to common acceptation, to have paid you, without rendering you a further fet of fervices, and thofe of another fort: a fet of fervices, which are rendered by the exercifing of certain acts of a phyfical nature upon the very thing with which he is faid to pay you : to wit, by transferring the thing to a certain place where you may be fure to find. it, and where it may be convenient for you to receive it. But thefe fervices, although the obligation of rendering them fhould be annexed by law to the obligation of rendering thofe other fervices in the performance of which the operation of payment properly confifts, are plainly ads of a diftinct nature : nor are they effeptial to the operation : by themfelves they do not conftitute it, and it may be performed without them. It muft be performed without them wherever the thing to be transferred happens to be already as much within the reach, phyfically fpeaking, of the creditor, as by any act of the debtor it can be made to be.

This matter would have appeared in a clearer light had it been practicable to enter here into a full examination of the nature of property, and the feveral modifications of which it is fufceptible: but every thing cannot be done at once.

n Under wrongful with-holding of fervices is included breach of contratt : for the obligation to render fervices may be grounded either on contract, or upon other titles: in other words, the event of a man's engaging in a contract is one out of many other inveftitive events from which the right of receiving them may take its commencement. See ch, xvii. [Limits] \$iv.

Were the word fervices to be taken in its utmoft latitude (negative included as well as pofitive) this one head would cover the whole law. To this place then are to be referred fuch fervices only, the with-holding of which does not coincide with any of the other offences for which feparate denominations have been provided.

* Supra, xxvi. 
INTROD of your teach. In the former gafe, the nature of the change is

CAAP. XVE either fuch as to put it out of your power to make any ufe of it at all, in which cafe the thing is faid to be defroyed, and the offence whereby it is fo treated may be termed vorongful deftruction: or fuch only as to render the ufes it is capable of being put to of lefs value than before, in which cafe it is faid to be damaged, or to have funtained damage, and the offence may be termed wrongful endamagement. Moreover, in as far as the value which a thing is of to you is confidered as being liable to be in fome degree impaired by any act on the part of any other perfon exercifed upon that thing, although on a given occafion no perceptible damage hould enfue, the exercife of any fuch act is commonly treated on the footing of an offence, which may be termed wrongful ufing or occupation.

If the caufe of the thing's failing in its capacity of being of ufe to you, lies in the exterior fituation of it with relation to you, the offence may be ftiled wrongful detainment ${ }^{\circ}$. Wrongful detainment, during any given period of time, may either be accompanied with the intention of detaining the thing for ever (that is, for an indefinite time) or not: if it be, and if it be accompanied at the fame time with the intention of not being amenable to law for what is done, it feems to anfwer to the idea commonly annexed to the word embezzlement : an offence which is commonly accompanied with breach of truft ${ }^{p}$. In the cafe of wrongful occupa-

\footnotetext{
- In the Englih law, detinue and detainer: detinue applied chiefly to moveables; detainer to immoveables. Under detinue and detainer cafes are alfo comprifed, in which the offence confifts in forbearing to transfer the legal poffeffion of the thing: fuch cares may be confidered as coming under the head of wrongful non-inveftment. The diftinction between mere phyfical poffefion and legal poffefion, where the latter is fhort-lived and defeafible, feems fcarcely hitherto to have been attended to. In a multitude of inftances they are confounded under the fame expreffions: The caure is. that probably under all laws, and frequently for very good reafons, the legal poffefion, with whatever certainty defeafible upon the event of a trial, is, down to the time of that event, in many cafes annexed to the appearance of the phyfical.
}

p In attempting to exhibit the import belonging to this and other names of offences in common ufe, I muft be underftood to fpeak all along with the utmoft diffidence. The truth is, the import given to them is commonly neither determinate nor uniform : fo that in the nature of things, no definition that can be given of them by a private perfon can be altogether an exact one. To fix the fenfe of them belongs only so the legillator. 
tion, the phyfical faculty of occupying may have been obtained with or without the affiftance or confent of the proprietor, or other perfon appearing to have a right to afford fuch' affiftance or confent. If without fuch affiftance or confent, and the occupation be accompanied with the intention of detaining the thing for ever, together with the intention of not being amenable to law for what is done, the offence feems to anfwer to the idea commonly annexed to the word theft or ftealing. If in the fame circumftances a force is put upon the body of any perfon who ufes, or appears to be difpofed to ufe, any endeavours to prevent the act, this feems to be one of the cafes in which the offence is generally underftood to come under the name of robbery.

If the phyfical faculty in queftion was obtained with the affiftance or confent of a proprietor or other perfon above fpoken of, and ftill the occupation of the thing is an offence, it may have been either becaufe the affiftance or confent was not fairly, or becaufe it was not freely, obtained. If not fairly obtained, it was obtained by falihood, which, if advifed, is in fuch a cafe termed fraud: and the offence, if accompanied with the intention of not being amendble to law, may be termed fraudulent obtainment or defraudment 9 . If not freely obtained, it was obtained by force: to wit, either by a force put upon the body, which has been already mentioned, or by a force put upon the mind. If by a force put upon the mind, or in other words, by the application of coercive motives *, it muft be by producing the apprêthenfion of fome evil: which evil, if the act is an offence, muft be fome evil to which on the occafion in queftion the one perfon has no right to expofe the other. This is one cafe in which; if the offence be accompanied with the intention of detaining the thing for ever, whether it be or be not accompanied with the intention of not being amenable to law, it feems

q The remaining cafes come under the head of ufurpation, or wrongful inveftment of property. The diftinction feems hardly hitherto to have been attended to : it turns like another, mentioned above, upon the difinction between legal poffeffion and phyfical. The fame obfervation may be applied to the cafe of extortion hereafter following.

* Vide fupra, xxvii. p. ccxxxvii.

Vox. I.

$\mathrm{K} \mathrm{k}$ to 
INTROD. to agree with the idea of what is commonly meant by extortion. Now the Ciap. XVI. part a man takes in expofing another to the evil in queftion, muft be either a politive or a negative part. In the former cafe, again, the evil muft either be prefent or diftant. In the cafe then where the affiftance or confent is obtained by a force put upon the body, or where, if by a force put upon the mind, the part taken in the expofing a man to the apprehenfion of the evil is pofitive, the evil prefent, and the object of it his: perfon, and if at any rate the extortion, thus applied, be accompanied with the intention of not being amenable to law, it feems to agree with the remaining cafe of what goes under the name of robbery.

As to diffipation in breach of truft, this, when productive of a pecuniary profit to the truftee, feems to be one fpecies of what is commonly meant by peculation. Another, and the only remaining one, feems to confift in acts of occupation exercifed by the truftee upon the things which are the objects of the fiduciary property, for his own benefit, and to the damage of the beneficiary. As to robbery, this offence, by the manner in which the affiftance or confent is obtained, becomes an offence againft property and perfon at the fame time. Diffipation in breach of truft, and peculation, may perhaps be more commodiounly treated of under the head of offences againft truft $r$ After thefe exceptions, we have thirteen genera or principal kinds of offences againft property, which, when ranged in the order moft commodious for examination, may ftand as follows, viz. 1. Wrongful non-inveftment of property. 2. Wrongful intercepiion of property. 3. Wrongful diveftment of property. 4. Ufurpation of property. 5. Wrongful inveitment of property. 6. Wrongful withholding of fervices. 7. Wrongful deftruction or endamagement. 8. Wrongful occupation. 9. Wrongful detainment. Io. Embezzlement. I1. Theft. 12. Defraudment. I3 Extortion:

We

- Ufury, which, if it muft be an offenee, is an offence committed with confent, that is, with the confent of the party fuppofed to be injured, cannot merit a place in the catalogue of offences, unlefs the confent were either unfairly obtained or unfreely : in the firtt cafe, it coincides with defraudment; in the other, with extortion.

I. Semi-PUblic onfences. 1. Wrongful diveftment, interception, ufurpation, 
We proceed now to confider offences which are complex in their effects. Regularly, indeed, we thould come to offences againt condition; but it will be more convenient to fpeak firt of offences by which a man's intereft is affected in two of the preceding points at once.

\section{XXXVI.}

Firft then, with regard to offences which affect perfon and reputation together. When any man, by a mode of treatment which affects the perfon, injures the reputation of another, his end and purpofe muft have been either his own immediate pleafure, or that fort of reflected pleafure, which in certain circumftances may be reaped from the fuffering of another. Now the only immediate pleafure worth regarding, which any one can reap from the perfon of another, and which at the fame time is capable of affecting the reputation of the latter, is the pleafure of the venereal appetite ${ }^{*}$. This pleafure, then, if reaped at all, muft have been reaped either againft the confent of the party, or with confent. If with confent, the confent muft have been obtained either freely and fairly both, or freely but not fairly, or elfe not even freely; in which cafe the fairnefs is out of the queftion. If the confent be altogether wanting, the offence is called rape: if not fairly obtained, feduction fimply: if not freely, it may be called forcible feduction. In any cafe, either the offence has gone the length of confummation, of has ftopt fhort of that period: if it has gone that length, it takes one or other of the names juft mentioned: if not, it may be included alike in all cafes under the denomination of a fimple lafcivious injury. Laftly, to

\&c. of valuables, which are the property of a corporate body; or which are in the indifcriminate occupation of a neighbourhood; fuch as parifh churches, altars, relicks, and other articles appropriated to the purpofes of religion : or things which are in the indifcriminate occupation of the public at large; fuch as mile-ftones, market-houfes, exchanges, public gardens, and cathedrals. 2. Setting on foot what have been called bubbles, or fraudulent partnerhip, or gaming adventures; propagating falfe news, to raife or fink the value of ftocks, or of any other denomination of property.

II. SELP-REGarding offrnces. 1. Idlenefs. 2. Gaming. 3. Other fpecies of prodigality.

- See ch. v. [Pleafures and Pains.] 
INTROD. take the cafe where a man injuring you in your reputation, by proCrap. XVI. ceedings that regard your perfon, does it for the fake of that fort of pleafure which will fometimes refult from the contemplation of another's pain. Under thefe circumftances either the offence has actually gone the length of a corporal injury, or it has refted in menacement: in the firft cafe it may be ftiled a corporal infult; in the other, it may come under the name of infulting menacement. And thus we have $f i x$ genera, or kinds of offences, againft perfon and reputation together; which, when ranged in the order moft commodious for confideration, will ftand thus: 1. Corporal infults. 2. Infulting menacement. 3. Seduction. 4. Rape. 5. Forcible feduction. 6. Simple. lafcivious injuries :

\section{XXXVII.}

Offences againft perfon and property.
Secondly, with refpect to thofe which affect perfon and property together. That a force put upon the perfon of a. man may be among the means by which the title to property may be unlawfully taken away or acquired, has been already ftated *. A force of this fort then is a circumftance which may accompany the offences of wrongful interception, wrongful diveftment, ufurpation, and wrongful inveftment. But in thefe cafes the intervention of this circumftance does not happen to have given any new denomination to the offence ". In all or any of thefe cafes, however, by prefixing the epithet forcible, we may have fo many names of offences, which may either be confidered as conftituting fo many fpecies of the genera belonging to the divifion of offences againt property, or as fo many genera belonging to the divifion now before us. Among the offences that concern the enjoyment of the thing, the cafe is the fame with wrongful deftruction and wrongful endamagement; as alfo with wrongful occupation and wrongful detainment. As to the offence of wrongful occupation, it is only in the cafe where the thing occupied belongs to the clafs of "im-

I. SEMI-PUBEIC OFFENCBS-none.

II. SELP-REGARDING OFPENCEs, 1. Sacrifice of virginity, 2. Indecencies not public.

"In the technical language of the Englim law, property fo acquired is faid to be acquired by durefs. 
moveables, that, when accompanied by the kind of force in queftion, INTROD. has obtained a particular name which is in common ufe: in this cafe it is called forcible entry: forcible detainment, as applied alfo to immoveables, but only to immoveables, has obtained, among lawyers at leaft, the name of forcible detainer ${ }^{x}$. As to robbery, the relation which it bears to thefe other offences, and the claim which it has to a place in the divifion now before us, have been already ftated *. And thus we may diftinguifh ten genera, or kinds of offences, againft perfon and property together, which, omitting for concifenefs fake the epithet wrongful, will ftand thus: 1. Forcible interception of property. 2. Forcible diveftment of property. 3. Forcible ufurpation. 4. Forcible inveftment. 5. Forcible deftruction or endamagement. 6. Forcible occupation of moveables. 7. Forcible entry. 8. Forcible detainment of moveables. 9. Forcible detainment of immoveables. 10. Robbery ".

\section{XXXVIII:}

We come now to offences againft condition. A man's condition of offences. ftation in life is conftituted by the legal relation he bears to the per- againft confons who are about him; that is, as we have already had occafion to fhew $t$, by duties, which, by being impofed on one fide, give birth to rights or powers on the other. Thefe relations, it is evident, may be almoft infinitely diverffied. Some means, however, may be found of circumfribing the field within which the varieties of them are difplayed. In the firft place, they mut either be fuch as are capable of

* Applied to moveables, the circumftance of force has never, at leaft by the technical part of the language, been taken into account : no fuch combination of terms as forcible occupation is in current ufe. The word detinue is applied to moveables only : and (in the language of the law) the word forcible has never been combined with it. The word applied to immoveables is detainer: this is combined with the word forcible : and what is fingular, it is fcarcely in ufe without that word. It was impoffible to fteer altogether clear of this technical nomenclature, on account of the inHuence which it has on the body of the language.

Y I. SEMI-PUBLIC OFFENCEs. 1. Incendiarifm. 2. Wrongful inundation.

1I. SBLF-REGARDING OFFENCES-none.

- Supra, Xxxvo.

+ Supra, xxv. note [r].

\section{Conditions,} domeftic or civil. 
INTROD. difplaying themfelves within the circle of a private family, or fuch as Chap. XVI. require a larger fpace. The conditions conftituted by the former fort of relations may be ftiled domeftic: thofe conftituted by the latter, civil.

\section{XXXIX.}

Domeftic conditions grounded on natural re. lationfhips.

As to domertic conditions, the legal relations by which they are conftituted may be diftinguifhed into $\mathbf{I}$. Such as are fuperadded to relations purely natural : and 2. Such as, without any fuch natural bafis, fubfift purely by inftitution. By relations purely natural, I mean thofe which may be faid to fubfift between certain perfons in virtue of the concern which they themfelves, or certain other perfons, have had in the proeefs which is neceffary to the continuance of the fpecies. Thefe relations may be diftinguifhed, in the firft place, into contiguous and uncontiguous. The uncontiguous fubfift through the intervention of fuch as are contiguous. The contiguous may be dittinguifhed, in the firft place, into connubial, and poft-connubial:. Thofe which may be termed connubial are two: I. That which the male bears towards the female: 2. That which the female bears to the male:. The poft-connubial are either productive or derivative. The productive is that which the male and female above-mentioned bear each of them towards the children

who

By the terms connubial and poft-connubial, all I mean at prefent to bring to view is, the mere phyfical union, apart from the ceremonies and legal eng?gements that will afterwards be confidered as accompanying it.

2 The vague and undetermined nature of the fictitious entity, called a relation, is, on occafions like the prefent, apt to be productive of a good deal of confufion. A relation is either faid to be borne by one of the objects which are parties to it, to the other, or to fubffs besween them. The latter mode of phrafeology is, perhaps, rather the more common. In fuch cafe the idea feems to be, that from the confideration of the two objects there refults but one relation, which belongs $2 s$ it were in common to them both. In fome cafes, this perhaps may anfwer the purpofe very well : it will not, however, in the prefent cafe. For the prefent purpofe it will be neceffary we thould conceive two relations as refulting from the two objects, and borne, fince fuch is the phrafe, by the one of them to or towards the other: one relation borne by the 
who are the immediate fruit of their union; this is termed the relation INTROD. of parentality. Now as the parents muft be, fo the children may be, СнÁ. XVI. of different fexes. Accordingly the relation of parentality may be diftinguifhed into four fpecies: 1. That which a father bears to his fon: this is termed paternity. 2. That which a father bears to his. daughter: this alfo is termed paternity. 3. That which a mother bears to her fon: this is called maternity. 4. That which a mother bears to her daughter : this alfo is termed maternity. Uncontiguous natural relations may be diftinguinhed into immediate and remote. Such as are immediate, are what one perfon bears to another in confequence of their bearing each of them one fimple relation to fome third perfon. Thus the paternal grandfather is related to the paternal grandfon by means of the two different relations, of different kinds, which together they bear to the father: the brother on the father's fide, to the brother, by means of the two relations of the fame kind, which together they bear to the father. In the fame manner we might proceed to find places in the fyltem for the infinitely-diverfified relations which refult from the combinations that may be formed by mixing together the feveral forts of relationfhips by afcent, relationfhips by defcent, collateral relationhips, and relationhips by affinity: which latter, when the union between the two parties through whom the affinity takes place is fanctioned by matrimonial folemnities, are termed relationhips by marriage. But this, as it would be a moft intricate and tedious talk, fo happily is it, for the prefent purpofe, an unneceffary one. The only natural relations to which it will be neceffary to pay any particular attention, are thofe which, when fanctioned by law, give birth to the conditions of hurband and wife, the two relations comprized under the

firft object to the fecond: another relation borne by the fecond object to the firf. This is neceffary on two accounts: 1. Becaufe for the relations themfelves there are in many inftances feparate names: for example, the relations of guardianfhip and wardihip : in which cafe, the fpeaking of them as if they were but one, may be productive of much confufion. 2. Becaufe the two different relationthips give birth to fo many conditions : which conditions are fo far different, that what is predicated and will hold good of the one, will, in various particulars, as we thall fee, not hold good of the other. 
INTROD. head of parentality, and the correfponding relations comprized undes Chap. XVI. the head of filiality or filiation.

What then are the relations of a legal kind which can be fuperinduced upon the above-mentioned natural relations? They muft be fuch as it is the nature of law to give birth to and eftablim. But the relations which fubfift purely by inftitution exhauft, as we thall fee, the whole ftock of relationfhips which it is in the nature of the law to give birth to and eftablifh. The relations then which can be fuperinduced upon thofe which are purely natural, cannot be in themfelves any other than what are of the number of thofe which fubfint purely by inftitution : fo that all the difference there can be between a legal relation of the one fort, and a legal relation of the other fort, is, that in the former cale the circumftance which gave birth to the natural relation ferves as a mark to indicate where the legal relation is to fix : in the latter cafe, the place where the legal relation is to attach is determined not by that circumftance but by fome other. From thefe confiderations it will appear manifeftly enough, that for treating of the feveral forts of conditions, as well natural as purely conventional, in the moft commodious order, it will be neceffary to give the precedence to the latter. Proceeding throughout upon the fame principle, we fhall all along give the priority, not to thofe which are firt by nature, but to thofe which are moft fimple in point of defcription. There is no other way of avoiding perpetual anticipations and repetitions.

$\mathrm{XL}$.

Domeftic relations which are purely of legal inftitution.
We'come now to confider the domeftic or family relations, which are purely of legal inftitution. It is to thefe in effect, that both kinds of domeftic conditions, confidered as the work of law, are indebted for their origin. When the law, no matter for what purpofe, takes upon itfelf to operate, in a matter in which it has not operated before, it can only be by impofing obligation *. Now when a legal obligation is impofed on any man, there are but two ways in which it can in the firft inftance be enforced. The one is by giving the power of enforcing it to the party in whofe favour it is impofed: the other

- See ch. xvii. [Limits] \$iii. 


\section{[D I V I S I O N] of offences.}

is by referving that power to certain third perfons, who, in virtue of their poffeffing it, are ftiled minifters of juftice. In the firft cafe, the party favoured is faid to poffefs not only a right as againft the party obliged, but alfo a power over him: in the fecond cafe, a rigbt only, uncorroborated by power. In the firft cafe, the party favoured may be ftiled a fuperior, and as they are both members of the fame family, a domeftic fuperior, with reference to the party obliged: who, in the fame cafe, may be ftiled a domeftic inferior, with reference to the party favoured. Now in point of poffibility, it is evident, that domeftic conditions, or a kind of fictitious poffeffion analogous to domeftic conditions, might have been looked upon as conftituted, as well by rights alone, without powers on either fide, as by powers. But in point of utility ${ }^{b}$ it does not feem expedient: and in point of fact, probably

b Two perfons, who by any means ftand engaged to live together, can never live together long, but one of them will choofe that fome act or other thall be done, which the other will choofe fhould not be done. When this is the cafe, how is the competition to be decided ? Laying afide generofity and good-breeding, which are the tardy and uncertain fruits of long-eftablined laws, it is evident that there can be no certain means of deciding it but phyfical power: which indeed is the very means by which family as well as other competitions muft have been decided, long before any fuch office as that of legiflator had exiftence. This then being the order of things which the legifator finds eftablioned by nature, how fhould be do better than to acquiefce in it? The perfons who by the influence of caufes that prevail every where, ftand engaged to live together, are, I. Parent and child, during the infancy of the latter: 2. Man and wife: 3 . Children of the fame parents. Parent and child, by necerfity : fince, if the child did not live with the parent (or with fomebody ftanding in the place of the parent) it could not live at all : huband and wife, by a choice approaching to neceffity : children of the fame parents, by the neceffity of their living each of them with the parents. As between parent and child, the neceffity there is of a power on the part of the parent for the prefervation of the child fuperfedes all farther reafoning. As between man and wife, that necefity does not fubfift. The only reafon that applies to this cafe is, the neceffity of putting an end to competition. The man would have the meat roafted, the woman boiled: Thall they both faft till the judge comes in to drefs it for them? The woman would have the child dreffed in green; the man, in blue: Shall the child be naked till the judge comes in to clothe it? This affords a reafon for giving a power to one or other of the parties: but it affords none for giving the power to the one rather than to the other. How then thall the legillator determine?

Vol. I.

L. 1 Suppofing 
INTROD. probably owing to the invariable perception which men muft have had CHAP. XVI. of the inexpediency, no fuch conditions feem ever to have been conftituted by fuch feeble bands. Of the legal relationfhips then, which are capable of being made to fublift within the circle of a family, there remain thofe only in which the obligation is enforced by power: Now then, wherever any fuch power is conferred, the end or purpofe for which it was conferred (unlefs the leginlator can be fuppofed to act without a motive) muft have been the producing of a benefit to fomebody: in other words, it muft have been conferred for the fake of fomebody. The perfon then, for whofe fake it is conferred, mult either be one of the two parties juft mentioned, or a third party : if one of thefe two, it muft be either the fuperior or the inferior. If the fuperior, fuch fuperior is commonly called a maftex; and the inferior is termed his fervant: and the power may be termed a beneficial one. If it be for the fake of the inferior that the power is eltablifhed, the fuperior is termed' a guardian; and the inferior his ward': and the power, being thereby coupled with a truft, may be termed a fiduciary. one. If for the fake of a third party, the fuperior may be termed a

Suppofing it equally eafy to give it to either, let him look ever fo long for a reafon why he thould give it to the one rather than to the other, and he may look in vain. But how does the matter ftand already ? for there were men and wives (or, what comes to the fame thing, male and female living together as man and wife) before there were leginlators. Looking round him then, he finds almoft every where the male the ftronger of the two; and therefore poffefing already, by purely phyfical means, that power which he is thinking of beftowing on one of them by means of law. How then can he do fo well as by placing the legal power in the fame hands which are beyond comparifon the more likely to be in poffeffion of the phyfical? in this way, few tranfgreffions, and few calls. for punifhment: in the other way, perpetual tranfgreffions, and perpetual calls for punifhment. Solon is faid to have transferred the fame idea to the diftribution of ftate powers. Here then was generalization: here was the work of genius. But in the difpolal of domeftic power, every legillator, without any effort of genius; has been a Solon. So much for reafons": add to which, in point of motives $t$, that le gilators feem all to have been of the male fex, down to the days of Catherine. I fpeak here of thofe who frame laws, not of thofe who touch them with a feepter.

* Social motives: fympathy for the public : love of reputation, \&c,

+ Self-regarding motives: or focial motives, which are focial in a lefs extent: fympathy for perfons of a particular defcription: perfons of the fame fex.

fuperintendant; 
fuperintendant; and the inferior his fubordinate. This third party will INTROD. either be an affignable individual or fet of individuals, or a fet of unaffignable individuals. In this latter cafe the truft is either a public or a femi-public one: and the condition which it conftitutes is not of the domeftic, but of the civil kind. In the former cafe, this third party or principal, as he may be termed, either has a beneficial power over the fuperintendant, or he has not: if he has, the fuperintendant is his fervant, and confequently fo alfo is the fubordinate: if not, the fuperintendant is the mafter of the fubordinate; and all the advantage which the principal has over his fuperintendant, is that of poffeffing a fet of rights, uncorroborated by power; and therefore, as we have feen *, not fit to conftitute a condition of the domeftic kind. But be the condition what it may which is conftituted by thefe rights, of what nature can the obligations be, to which the fuperintendant is capable of being fubjected by means of them? They are neither more nor lefs than thofe which a man is capable of being fubjected to by powers. It follows, therefore, that the functions of a principal and his fuperintendant coincide with thofe of a mafter and a fervant; and confequently that the offences relative to the two former conditions will coincide with the offences relative to the two latter.

\section{XLI.}

Offences to which the condition of a mafter, like any other kind of condition, is expofed, may, as hath been already intimated $t$; be diftinguifhed into fuch as concern the exiftence of the condition it condition of felf, and fuch as concern the performance of the functions of it, while fubfifting. Firft then, with regard to fuch as affect its exiftence. It is obvious enough that the fervices of one man may be a benefit to another : the condition of a mafter may therefore be a beneficial one. It ftands expofed, therefore, to the offences of wrongful non-inveftment, wrongful interception, ufurpation, wrongful invefment, and wrongful diveftment. But how hould it ftand expofed to the offences of wrongful abdication, wrongful detrectation, and wrongful impofition? Certainly it cannot of itfelf; for fervices, when a man has the power 
INTROD. of exacting them or not, as he thinks fit, can never be a burthen. CHAP. XVI. But if to the powers, by which the condition of a mafter is conftituted, the law thinks fit to annex any obligation on the part of the mafter; for inftance, that of affording maintenance, or giving wages, to the fervant, or paying money to any body elfe; it is evident that, in virtue of fuch obligation, the condition may become a burthen. In this cafe, however, the condition poffeffed by the mafter will not, properly fpeaking, be the pure and fimple condition of a mafter : it will be a kind of complex object, refolvable into the beneficial condition of a mafter, and the burthenfome obligation which is annexed to it. Still however, if the nature of the obligation lies within a narrow compafs, and does not, in the manner of that which contitutes a truft, interfere with the exercife of thofe powers by which the condition of the fuperior is conftituted, the latter, notwithftanding this foreign mixture, will ftill retain the name of mafterhip ${ }^{c}$. In this cafe therefore, but not otherwife, the condition of a mafter may ftand expofed to the offences of wrongful abdication, wrongful detrectation, and wrongful impofftion. Next as to the behaviour of perfons: with reference to this. condition, while confidered as fubfifting. In virtue of its being a benefit, it is expofed to difurbance. This difturbance will either be the offence of a ftranger, or the offence of the fervant himfelf. Where it is the offence of a ftranger, and is committed by taking the perfon of the fervant, in circumftances in which the taking of an object belonging to the clafs of things would be an act of theft, or (what is fcarcely worth diftinguifhing from theft) an act of embezzlement, it may be termed fervant-ftealing. Where it is the offence of the fervant himfelf, it is ftiled breach of duty. Now the moft flagrant fpecies of breach of duty, and that which includes indeed every other, is that which confifts in the fervant's withdrawing himfelf from the place in

c In moft civilized nations there is a fort of domeftic condition, in which the fuperior is termed a mafter, while the inferior is termed fometimes indeed a fervant, but more particularly and more frequently an apprentice. In this cafe, though the fuperior is, in point of ufage, known by no other name than that of a mafter, the relationfhip is in point of fact a mixt one, compounded of that of mafer and that of guardian.

which. 
which the duty fhould be performed. This fpecies of breach of duty is termed elopemont. Again, in virtue of the power belonging to this condition, it is liable, on the part of the mafter, to abufe. But this power is not coupled with a truft. The condition of a mafter is therefore not expofed to any offence which is analogous to breach of truit. Laftly, on account of its being expofed to abufe, it may be conceived to ttand, in point of poflibility, expofed to bribery. But confidering how few, and how infignificant, the perfons are who are liable to be fubject to the power here in quettion, this is an offence which, on account of the want of temptation, there will feldom be any example of in practice. We may therefore reckon thirteen forts of offences to which the condition of a mafter is expofed; viz, 1 . Wrongful noninveftment of mafterhip. 2. Wrongful interception of malterhip. 3. Wrongful diveftment of mafterhip. 4: Ufurpation of matterfhip. 5. Wrongful inveftment of mafterphip. 6. Wrongful abdication of matterhip. 7. Wrongful detreetation of matterhip. 8. Wrongful impoftion of mafterhip. 9. Abufe of mafterhip. 10. Difturbance of mafterhip. 11. Breach of duty in fervants. 12. Elopement of fervants. 3. Servant-ftealing.

\section{XLII.}

As to the power by which the condition of a mafter is conftituted, Various. this may be either limited or unlimited. When it is altogether un- modes of ferlimited, the condition of the fervant is ftiled pure flavery. But as the rules of language are as far as can be conceived from being fteady on this head, the term navery is commonly made ufe of wherever the limitations prefcribed to the power of the mafter are looked upon as inconfiderable. Whenever any fuch limitation is prefcribed, a kind of fictitious entity is thereby created, and, in quality of an incorporeal object of poffeffion, is bettowed upon the fervant: this object is of the clafs of thofe which are called rigbts: and in the prefent cafe is termed, in a more particular manner, a liberty; and fometimes a privilege, an immunity, or an exemption. Now thofe limitations on the one hand, and thefe liberties on the other, may, it is evident, be as various as the acts (pofitive or negative) which the mafter may or may not have the power of obliging the fervant to fubmit to or to perform. Correfpondent 
INTROD. refpondent then to the infinitude of thefe liberties, is the infinitude of Crap. XVI. the modifications which the condition of mafterhip (or, as it is more common to fay in fuch a cafe, that of fervitude) admits of. Thefe modifications, it is evident, may, in different countries, be infinitely diverfified. In different countries, therefore, the offences characterized by the above names will, if fpecifically confidered, admit of very different defcriptions. If there be a fpot upon the earth fo wretched as to exhibit the fpectacle of pure and abfolutely unlimited navery, on that fpot there will be no fuch thing as any abufe of mafterhip; which means neither more nor lefs than that no abufe of mafterfhip will there be treated on the footing of an offence. As to the queftion, Whether any, and what, modes of fervitude ought to be eftablinhed or kept on foot? this is a queftion, the folution of which belongs to the civil branch of the art of leginlation.

XLIII.

Offences Next, with regard to the offences that may concern the condition couching the of a fervant. It might feem at firft fight, that a condition of this kind fervant. could not have a fpark of benefit belonging to it: that it could not be attended with any other confequences than fuch as rendered it a mere burthen. But a burthen itfelf may be a benefit, in comparifon of a greater burthen. Conceive a man's fituation then to be fuch, that he muft, at any rate, be in a ftate of pure navery. Still may it be material to him, and highly material, who the perfon is whom he has for his mafter. A ftate of lavery then, under one mafter, may be a beneficial ftate to him, in comparifon with a Atate of flavery under another mafter. The condition of a fervant then is expofed to the feveral offences to which a condition, in virtue of its being a beneficial one, is expofed 4 . More than this, where the power of the

a It may feem at firf, that a perfon who is in the condition of a flave, could not have it in his power to engage in fuch courfe of proceeding as would be neceffary, in order to give him an apparent title to be reckoned among the laves of another mafter. But though a flave in point of right, it may happen that he has eloped for inftance, and is not a flave in point of fact: or, fuppofe him a llave in point of fact, and ever fo vigilantly guarded, fill a perfon connected with him by the ties of fympathy, might do that for him which, though willing and affenting, he might not be able to do for himfelf: might forge a deed of donation, for example, from the one mafter to the other. 


\section{[D I V I S I O N] of offences.}

mafter is limited, and the limitations annexed to it, and thence the INTROD. liberties of the fervant, are confiderable, the fervitude may even be pofitively eligible. For amongt thofe limitations may be fuch as are fufficient to enable the fervant to poffefs property of his own: being capable then of poffeffing property of his own, he may be capable of receiving it from his mafter: in fhort, he may receive wages, or other emoluments, from his mafter: and the benefit refulting from thefe wages may be fo confiderable as to outweigh the burthen of the fervitude, and, by that means, render that condition. more beneficial upon the whole, and more eligible, than that of one who is not in any refpect under the controul of any fuch perfon as a mafter. Accordingly, by thefe means the condition of the fervant may be fo eligible, that his entrance into it, and his continuance in it, may have been altogether the refult of his own choice.

That the nature of the two conditions may be the more clearly underftood, it may be of ufe to thew the fort of correfpondency there is between the offences which affect the exiftence of the one, and thofe which affect the exiftence of the other. That this correfpondency cannot but be very intimate is obvious at firft fight. It is not, however, that a given offence in the former catalogue coincides with an offence of the fame name in the latter catalogue : ufurpation of fervanthip with ufurpation of mafterhip, for example. But the cafe is, that an offence of one denomination in the one catalogue coincides with an offence of a different denomination in the other catalogue. Nor is the coincidence conftant and certain : but liable to contingencies, as we thall fee. Firft then, wrongful non-inveftment of the condition of a fervant, if it be the offence of one who thould have been the mafter, coincides with wrongful detrectation of mafterhip: if it be the offence of a third perfon, it involves in it non-inveftment of mafterfhip, which, provided the mafterhip be in the eyes of him who hould have been malter a beneficial thing, but not otherwife, is wrongful. 2. Wrongful interception of the condition of a fervant, if it be the offence of him who hould have been mafter, coincides with wrongful detrectation of mafterhip: if it be the offence of a third perfon, and the mafterihip be a beneficial thing, it involves in it wrongful interception 
INTROD. of mafterhip. 3. Wrongful divertment of fervanthip, if it be the CHAP.XVI. offence of the mafter, but not otherwife, coincides with wrongful abdication of mafterhip: if it be the offence of a ftranger, it involves in it diveftment of mafternhip, which, in as far as the mafterhip is a beneficial thing, is wrongful. 4. Ufurpation of fervanthip coincides neceffarily with wrongful impofition of mafterhip: it will be apt to involve in it wrongful diveftment of mafterfhip: but this only in the cafe where the ufurper, previoufly to the ufurpation, was in a ftate of fervitude under fome other mafter. 5. Wrongful inveftment of fervanthip (the fervanthip being confidered as a beneficial thing) coincides with impofition of mafterfhip; which, if in the eyes of the pretended mafter the mafterhip fhould chance to be a burthen, will be wrongful. 6. Wrongful abdication of fervanthip coincides with wrongful diveftment of mafterhip. 7. Wrongful detrectation of fervanthip, with wrongful non-inveftment of mafterhip. 8. Wrongful impofition of fervanthip, if it be the offence of the pretended mafter, coincides with ufurpation of mafternip : if it be the offence of a ftranger, it involves in it impofition of mafterhip, which, if in the eyes of the pretended matter the mafterhip hould be a burthen, will be wrongful. As to abufe of mafterhip, difturbance of mafterthip, breach of duty in fervants, elopement of fervants, and fervantftealing, thefe are offences which, without any change of denomination, bear equal relation to both conditions. And thus we may reckon thirteen forts of offences to which the condition of a fervant ftands expofed : viz. I. Wrongful non-inveftment of fervanthip. 2. Wrongful interception of fervanthip. 3. Wrongful diveftment of fervantthip. 4. Ufurpation of fervanthip. 5. Wrongful inveftment of fervantihip. 6. Wrongful abdication of fervanthip. 7. Wrongful detrectation of fervanthip. 8. Wrongful impofition of fervanthip. 9. Abufe of mafterfhip. 10. Difturbance of mafterhip. II. Breach of duty in fervants. 12. Elopement of fervants. 13. Servantftealing. 
another, living within the compafs of the fame family, and called a INTROD. ward; the power being to be exercifed for the benefit of the ward. Now then, what are the cafes in which it can be for the benefit of one man, that another, living within the compafs of the fame family, thould exercife power over him? Confider either of the parties by himfelf, and fuppofe him, in point of undertanding, to be on a level with the other, it feems evident enough that no fuch cafes can ever exift :. To the production of happinefs on the part of any given perfon (in like manner as to the production of any other effect which is the refult of human agency)* three things it is neceffary thould concur: knowledge, inclination, and phyfical power. Now as there is no man who is fo fure of being inclined, on all occafions, to promote your happinefs as you yourfelf are, fo neither is there any man who upon the whole can have had fo good opportunities as you muft have had of knowing what is moft conducive to that purpofe. For who thould know fo well as you do what it is that gives you pain or pleafure + ? Moreover, as to power, it is manifeft that no fuperiority in this refpeet on the part of a ftranger, could, for a conftancy, make up for to great a deficiency as he muft lie under in refpect of two fuch material points as knowledge and inclination. If then there be a cafe where it can be for the advantage of one man to be under the power of another, it muft be on account of fome palpable and very confiderable deficiency, on the part of the former, in point of intellects, or (which is the fame thing in other words) in point of knowledge or underftanding. Now there are two cafes in which fuch palpable deficiency is known to take place. Thefe are, I. Where a man's intellect is not yet arrived at that ftate in which it is capable of directing his own inclination in the purfuit of happinefs: this is the cafe of infancy $\neq$. 2. Where by fome particular

confider them togetber indeed, take the fum of the two interefts, and the cafe, as we have feen (fupra, xl.) is then the reverfe. That cafe, it is to be remembered, proceeds only upon the fuppofition that the two parties are obliged to live together; for fuppofe it to be at their option to part, and the necefity of eftablifhing the power ceares.

"See infra, liv. note. + Ch. xvii. [Limits] $\$$ i. ICh. xiii. [Cafes unmeet] $\$$ iii.

Voz. I.

M m

known 


\section{ccluvi [D I V I S I I O N] of offences.}

INTROD. known of unknown circumftance his intellet has either never arrived CHAPY XVI. at that ftate, or having arrived at it has fallen from it: which is the cafe of infanity.

By what means then is it to be afcertained whether $: 2$ man's intelleet is in that ftate or no? For exhibiting the quantity of fenfible heat in a human body we have a very tolerable fort of inftrument, the thermometer; but for exhibiting the quantity of intelligence, we have no fuch inftrument. It is evident, therefore, that the line which feparates the quantity of intelligence which is fufficient for the purpofes of felfgovernment from that which is not fufficient, muft be, in a great meafure, arbitrary. Where the infufficiency is the refult of want of age, the fufficient quantity of intelligence, be it what it may, does not accrue to all at the fame period of their lives. It becomes therefore neceffary for leginators to cut the gordian knot, and fix upon a particular period, at which and not before, truly or not, every perfon whatever thall be deemed, as far as depends upon age, to be in poffeffion of this fufficient quantity ${ }^{\xi}$. In this cafe then a line is drawn which may be the fame for every man, and in the defcription of which, fuch as it is, whatever perfons are concerned may be certain of agreeing: the circumftance of time affording a mark by which the line in queftion may be traced with the utmoft degree of nicety. On the other hand, where the infufficiency is the refult of infanity, there is not even this refource: fo that here the leginator has no other expedient than to appoint fome particular perfon or perfons to give a particular determination of the queftion, in every inftance in which it occurs, according to his or their particular and arbitrary difcretion.

\footnotetext{
f In certain nations, women, whether married or not, have been placed in a ftate of perpetual wardhip: this has been evidently founded on the notion of a decided inferiority in point of intellects on the part of the female fex, analogous to that which is the refult of infancy or infanity on the part of the male. This is not the only inftance in which tyranny has taken advantage of its own wrong, alledging as a reafon for the domination it exercifes, an imbecillity, which, as far as it has been real, has been produced by the abufe of that very power which it is brought to juftify. Ariftotle, fafcinated by the prejudice of the times, divides mankind into two diftinet fpecies, that of freemen, and that of flaves. Certain men were born to be flaves, and ought to be naves. -Why? Becaufe they are fo.
} 


\section{$\left[\begin{array}{lllllllll}D & I & V & I & S & 1 & 0 & N\end{array}\right]$ of offences.}

Arbitrary enough it muft be at any rate, fince the only way in which it can be exercifed is by confidering whether the fhare of intelligence poffeffed by the individual in queftion does or does not come up to the loofe and indeterminate idea which perfons fo appointed may chance to entertain with refpect to the quantity which is deemed fufficient.

\section{XLV.}

The line then being drawn, or fuppofed to be fo, it is expedient to a man who cannot, with fafety to himfelf, be left in his own power, that he fhould be placed in the power of another. How long then thould he remain fo ? Juft fo long as his inability is fuppofed to continue : that is, in the cafe of infancy, till he arrives at that period at which the law deems him to be of full age: in the cafe of infanity, till he be of found mind and underftanding. Now it is evident, that this period, in the cafe of infancy, may not arrive for a confiderable time : and in the cafe of infanity, perhaps never. The duration of the power belonging to this truft muft therefore, in the one cafe, be very confiderable; in the other cafe, indefinite.

\section{XLVI.}

The next point to confider, is what may be the extent of it? for as to what ought to be, that is a matter to be fettled, not in a general analytical fketch, but in a particular and circumftantial differtation. By poffibility, then, this power may poffefs any extent that can be it. inagined: it may extend to any acts which, phyfically fpeaking, it annexed to may be in the power of the ward to perform himfelf, or be the object of if exercifed by the guardian. Conceive the power, for a moment, to ftand upon this footing: the condition of the ward ftands now exactly upon a footing with pure navery. Add the obligation by which the power is turned into a truft: the limits of the power are now very confiderably narrowed. What then is the purport of this obligation? Of what nature is the courfe of conduet it prefcribes? It is fuch a courfe of conduct as thall be beft calculated for procuring to the ward the greateft quantity of happinefs which his faculties, and the circumftances he is in, will admit of : faving always, in the firft place, the regard which the guardian is permitted to fhew to his own happinefs; and, in the fecond place, that which he is obliged, 
INTROD. as well as permitted, to thew to that of other men. This is in CaAp. XVI. fact no other than that courfe of conduct which the ward, did he but know how, ought in point of prudence to maintain of himfelf : fo that the bufinefs of the former is to govern the latter precifely in the manner in which this latter ought to govern himfelf. Now to inttruet each individual in what manner to govern his own conduct in the details of life, is the particular bufinefs of private ethics : to inftruct individuals in what manner to govern the conduct of thofe whofe happinefs, during non-age, is committed to their charge, is the bufinefs of. the art of private education. The details, therefore, of the rules to be given for that purpofe, any more than the acts which are capable of being committed in violation of thofe rules, belong not to the art of legilation: fince, as will be feen more particularly hereafter*, fuch details could not, with any chance of advantage, be provided for by the leginator. Some general outlines might indeed be drawn by his authority: and, in point of fact, fome are in every civilized ftate. But fuch regulations, it is evident, muft be liable to great variation: in the firft place, according to the infinite diverfity of civil conditions. which a man may ftand invefted with in any given ftate: in the next: place, according to the diverfity of local circumftances that may influence the nature of the conditions which may chance to be eftablined in different ftates. On this account, the offences which would be conftituted by fuch regulations could not be comprifed under any concife and fettled denominations, capable of a permanent and extenfive application. No place, therefore, can be allotted to them here.

\section{XI.VII.}

Offences touching the condition of a guardian.
By what has been faid, we are the better prepared for taking an account of the offences to which the condition in queftion ftands expofed: Guardianfhip being a private truft, is of courfe expofed to thofe offences, and no others, by which a private truft is liable to be affected. Some of them, however, on account of the fpecial quality of the truft, will admit of fome further particularity of defcription. In the firft place; breach of this fpecies of truft may be termed mifmanagement of guardian- 
Thip: in the next place, of whatever nature the duties are which are capable of being annexed to this condition, it mutt often happen, that in order to fulfil them, it is neceffary the guardian hould be at a certain particular place. Mifmanagement of guardianhip, when it confifts in the not being, on the occafion in queftion, at the place in queftion, may be termed defertion of guardianhip. Thirdly, It is manifelt enough, that the object which the guardian ought to propofe to himfelf, in the exercife of the powers to which thofe duties are annexed, is to procure for the ward the greateft quantity of happinefs which can be procured for him, confittently with the regard which is due to the other interefts that have been mentioned: for this is the object which the wand would have propofed to himfelf, and might and ought to have been allowed to propofe to himfelf, had he been capable of governing his own conduct. Now, in order to procure this happinefs, it is neceffary that he thould poffefs a certain power over the objects on the ufe of which fuch happinefs depends. Thefe objects are either the perfon of the ward himfelf, or other objects that are extraneous to him. Thefe other objects are either things or perfons. As to things then, objects of this clafs, in as far as a man's happinels depends upor the ufe of them, are ftilea his property. The cafe is the fame with the fervices of any perfons over whom he may happen to poffers a beneficial power, or to whofe fervices he may happen to: poffers a beneficial right. Now when property of any kind which is in truft, fuffers by the delinquency of him with whom it is in truft, fuch offence, of whatever nature it is in other refpects, maybe ftiled diffpation in breach of truft:and if it be attended with a profit to the truftee, it may be ftiled peculation*. Fourthly, For one perfon to exercife a power of any kind over another, it is neceffary that the latter hould either perform certain acts, upon being commanded fo to do by the former, or at leaft thould fuffer certain acts to be exercifed upon himfelf. In this refpect a ward: muft ftand upon the footing of a fervant: and the condition of a ward muft, in this refpect, ftand expofed to the fame offences to which that of a fervant ftands expofed: that is, on the part of a. ftranger, to difturbance, which, in particular circumftances, will amount 
INTROD. to theft: on the part of the ward, to breach of duty: which, in part Criap. XVI. ticular circumftances, may be effeeted by elopement. Fifthly, There does not feem to be any offence concerning guardianhip that correfponds to abufe of truft: I mean in the fenfe to which the laft-mentioned denomination has been here confined*. The reafon is, that guardianfip, being a truft of a private nature, does not, as fuch, confer upon the truftee any power, either over the perfons or over the property of any party, other than the beneficiary himfelf. If by accident it confers on the truftee a power over any perfons whofe fervices conftitute a part of the property of the beneficiary, the truftee becomes thereby, in certain refpects, the mafter of fuch fervants $\dagger$. Sixthly, Bribery alfo is a fort of offence to which, in this cafe, there is not commonly much temptation. It is an offence, however, which by poffibility is capable of taking this direction: and muft therefore be aggregated to the number of the offences to which the condition of a guardian ftands expofed. And thus we have in all feventeen of thefe offences: viz. 1 . Wrongful non-inveftment of guardianfhip. 2. Wrongful interception of guardianhip. 3. Wrongful diveftment of guardianhip. 4. Ufurpation of guardianhip. 5. Wrongful inveftment of guardianhip. 6. Wrongful abdication of guardianhip. 7. Detrectation of guardianfhip. 8. Wrongful impofition of guardianhip. 9. Mifmanagement of guardianfip. 10. Defertion of guardianfhip. 11. Diffipation in prejudice of wardhip. I2. Peculation in prejudice of wardhip. 13. Difturbance of guardianfhip. 14. Breach of duty to guardians. 15 . Elopement from guardians. 16. Ward-ftealing. 17. Bribery in prejudice of wardhip.

\section{XLVIII.}

Offences touching the condition of a ward.
Next, with regard to offences to which the condition of wardhip is expofed. Thofe which fint affect the exiftence of the condition itfelf are as follows: 1 . Wrongful non-inveftment of the condition of a ward. This, if it be the offence of one who fhould have been guardian, coineides with wrongful detrectation of guardianhip: if it be the offence of a third perfon, it involves in it non-invertment of guardian-

- Vide fupra, xxv.

+ Vide fupra, $x l$. 
hip, which, provided the guardianhip is, in the eyes of him who thould have been guardian, a defirable thing, is wrongful. 2. Wrongful interception of wardhip. This, if it be the offence of him who fhould have been guardian, coincides with wrongful detrectation of guardianfhip : if it be the offence of a third perfon, it involves in it interception of guardianhip, which, provided the guardianfhip is, in the eyes of him who hould have been guardian, a defirable thing, is wrongful. 3. Wrongful diveftment of wardhip. This, if it be the offence of the guardian, but not otherwife, coincides with wrongful abdication of guardianhip: if it be the offence of a third perfon, it involves in it diveftinent of guardianhip, which, if the guardianhip is, in the eyes of the guardian, a defirable thing, is wrongful. 4. Ufurpation of the condition of a ward: an offence not very likely to be committed. This coincides at any rate with wrongful impofition of guardianhip: and if the ufurper were already under the guardianthip of another guardian, it will involve in it wrongful diveftment of fuch guardianhip ". 5. Wrongful invertment of wardfhip : (the wardhip being confidered as a beneficial thing). This coincides with impofition of guardianhip, which, if in the eyes of the pretended guardian the guardianfhip thould be a burthen, will be wrongful. 6. Wrongful abdication of wardhip. This coincides with wrongful diveftment of guardianhip. 7. Wrongful detrectation of wardhip. This coincides with wrongful interception of guardianhip. 8. Wrongful impofition of wardhip. This, if the offender be the pretended guardian, coincides with ufurpation of guardianhip: if a ftranger, it involves in it wrongful impofition of guardianhip. As to fuch of the offences relative to this condition, as concern the confequences of it while fubfifting, they are of fuch a nature that, without any change of denomi-

8 This effect it may be thought will not neceffarily take place : fince a ward may have two guardians. One man then is guardian by right: another man comes and makes himfelf fo by ufurpation. This may very well be, and yet the former may concinue guardian notwithftanding. How then (it may be afked) is he divefted of his guardianthip i-The anfwer is-Certainly not of the whole of it: but, however, of a part o it: of fuch part as is occupied, if one may fo fay, that is, of fuch part of the powers and rights belonging to it as are exercifed, by the ufurper. 
INTROD. nation, they belong equally to the condition of a guardian, and that CHAP.XVI. of a ward. We may therefore reckon feventeen forts of offences relative to the condition of a ward: 1. Wrongful non-inveftment of wardhip. 2. Wrongful interception of wardhip. 3. Wrongful diveftment of wardhip. 4. Ufurpation of wardhip. 5. Wrongful inveftment of wardhip. 6. Wrongful abdication of wardhip. 7. Wrongful detrectation of wardhip. 8. Wrongful impofition of wardhip. 9. Mifmanagement of guardianfhip. 1o. Defertion of guardianhip. 11. Diffipation in prejudice of wardhip. 12. Peculation in prejudice of wardhip. 13. Difturbance of guardianthip. 14. Breach of duty to guardians. 15. Elopement from guardians. 16. Ward-ftealing. 17. Bribery in prejudice of wardihip.

\section{XLIX.}

Offences touching the condition of a parent.
We come now to the offences to which the condition of a parent ftands expofed: and firf, with regard to thofe by which the very exiftence of the condition is affected. On this occafion, in order to fee the more clearly into the fubject, it will be neceffary to diftinguifh between the natural relationfhip, and the legal relationfhip which is fuperinduced as it were upon the natural one. The natural one being conftituted by a particular event, which, either on account of its being already paft, or on fome other account, is equally out of the power of the law, neither is, nor can be made, the fubjent of an offence. Is a man your father? It is not any offence of mine that can make you not his fon. Is he not your father? It is not any offence of mine that can render him fo. But although he does in faet bear that relation to you, I, by an offence of mine, may perhaps fo manage matters, that he thall not be thought to bear it : which, with refpect to any legal advantages which either he or you could derive from fuch relationhip, will be the fame thing as if he did not. In the capacity of a witnefs, I may caufe the judges to believe that he is not your father, and to decree accordingly: or, in the capacity of a judge, I may myfelf decree him not to be your father. Leaving then the purely natural relationthip as an object equally out of the reach of juftice and injuftice, the legal condition, it is evident, will ftand expofed to the fame offences, neither 


\section{[D I V I S I O N] of offences.}

cclxxiii

neither more nor lefs, as every other condition, that is capable of being INTROD. either beneficial or burthenfome, ftands expofed to. Next, with re- Crap.XVi. gard to the exercife of the functions belonging to this condition, confidered as ftill fubfifting. In parentality there muft be two perfons concerned, the father and the mother. The condition of a parent includes, therefore, two conditions; that of a father, and that of a mother, with refpect to fuch or fuch a child. Now it is evident, that between thefe two parties, whatever beneficiary powers, and other rights, as alfo whatever obligations, are annexed to the condition of a parent, may be thared in any proportions that can be imagined. But if in thefe feveral objects of legal creation, each of thefe two parties have feverally a thare, and if the interefts of all thefe parties are in any degree provided for, it is evident that each of the parents will ftand, with relation to the child, in two feveral capacities : that of a mafter, and that of a guardian. The condition of a parent then, in as far as it is the work of law, may be confidered as a complex condition, compounded of that of a guardian, and that of a mafter. To the parent then, in quality of guardian, refults a fet of duties, involving, as neceffary to the difcharge of them, certain powers: to the child, in the character of a ward, a fet of rights correfponding to the parent's duties, and a fet of duties correfponding to his powers. To the parent again, in quality of mafter, a fet of beneficiary powers, without any other neceffary limitation (fo long as they laft) than what is annexed to them by the duties incumbent on him in quality of a guardian : to the child, in the character of a fervant, a fet of duties correfponding to the parent's beneficiary powers, and without any other neceffary limitation (fo long as they laft) than what is annexed to them by the rights which belong to the child in his capacity of ward. The condition of a parent will therefore be expofed to all the offences to which either that of a guardian or that of a mafter are expofed : and, as each of the parents will partake, more or lefs, of both thofe characters, the offences to which the two conditions are expofed may be nominally, as they will be fubftantially, the fame. Taking them then all together, the offences to which the condition of a parent is expofed will ftand as Yox. I. $\mathrm{N} n$ follows: 
INTROD. follows: 1. Wrongful non-inveftment of parentality ". 2. Wrongful Cнap. XVI. interception of parentality. 3. Wrongful diveftment of parentality. 4. Ufurpation of parentality. 5. Wrongful inveftment of parentality. 6. Wrongful abdication of parentality. 7. Wrongful detrectation of parentality. 8. Wrongful impofition of parentality. 9. Mifmanagement of parental guardianthip. 10. Defertion of parental guardianfhip. II. Diffipation in prejudice of filial wardhip. 12. Peculation in prejudice of filial wardhip. I3. Abufe of parental powers. 14. Difturbance of parental guardianhip. 15. Breach of duty to parents. 16. Elopement from parents. 17. Child-ftealing. 18. B.ibery in prejudice of filial wardhip.

\section{L.}

Offences

touching the filfal condi-

tion.

Next with regard to the offences to which the filial condition ${ }^{i}$, the condition of a fon or daughter, ftands expofed. The principles to be purfued in the inveftigation of offences of this defcription, have already been fufficiently developed. It will be fufficient, therefore, to

h At firft view it may feem a folecifm to fpeak of the condition of parentality as one which a man can have need to be invefted with. The reafon is, that it is not common "for any ceremony to be required as neceffary to a man's being deemed in law the father of fuch or fuch a child. But the inftitation of fuch a ceremony, whether advifable or not, is at leaft perfectly conceivable. Nor are there wanting cafes in which it has actually been exemplified. By an article in the Roman law, adopted by many modern nations, an illegitimate child is rendered legitimate by the fubfequent marriage of his parents. If then a prieft, or other perfon whofe office it was, were to refure to join a man and woman in matrimony, fuch refufal, befides being a wrongful non-invertment with refpect to the two matrimonial conditions, would be a wrongful non-inveftment of parentality and filiation, to the prejudice of any children who thould have been legitimated.

i In Englith we have no word that will ferve to exprefs with propriety the perfon who bears the relation oppofed to that of parent. The word child is ambiguous, being employed in another fenfe, perhaps more frequently than in this: more frequentiy in oppofition to a perfon of full age, an adult, than in correlation to a parent. For the condition itfelf we have no other word than fliation: an ill-contrived term, not analogous to paternity and maternity: the proper term would have been filiality: the word filiation is as frequently, perhaps, and more confiftently, put for the act of eftablining a perfon in the poffeffion of the condition of filiality. 
enumerate them without further difcuffion. The only peculiarities by INTROD. which offences relative to the condition in queftion ftand diftinguifhed from the offences relative to all the preceding conditions, depend upon this one circumftance; viz. that it is certain every one muft have had a father and a mother: at the fame time that it is not certain that every one muft have had a mafter, a fervant, a guardian, or a ward. It will be obferved all along, that where a perfon, from whom, if alive, the benefit would be taken, or on whom the burthen would be impofed, be dead, fo much of the mifchief is extinct along with the object of the offence. There ftill, however, remains fo much of the mifchief as depends upon the advantage or difadvantage which might accrue to perfons related, or fuppofed to be related, in the feveral remoter degrees, to him in queftion. The catalogue then of thefe offences ftands as follows: 1. Wrongful non-inveftment of filiation. This, if it be the offence of him or her who thould have been recognized as the parent, coincides with wrongful detrectation of parentality: if it be the offence of a third perfon, it involves in it non-invertment of parentality, which, provided the parentality is, in the eyes of him or her who fhould have been recognized as the parent, a defirable thing, is wrongful. 2. Wrongful interception of filiation. This, if it be the offence of him or her who fhould have been recognized as the parent, coincides with wrongful detrectation of parentality : if it be the offence of a third perfon, it involves in it interception of parentality, which, provided the parentality is, in the eyes of him or her who hould have been recognized as parent, a defirable thing, is wrongful. 3. Wrongful diveftment of filiation. This, if it be the offence of him or her who thould be recognized as parent, coincides with wrongful abdication of parentality: if it be the offence of a third perfon, it involves in it divertment of parentality; to wit, of paternity, or of maternity, or of both; which, if the parentality is, in the eyes of him or her who mould be recognized as parent, a defrable thing, are refpectively wrongful. 4. Ufurpation of filiation. This coincides with wrongful impofition of parentality; to wit, either of paternity, or of maternity, or of both: and neceffarily involves in it diveftment of parentality, which, if the parentality thus divefted $\mathrm{N} n 2$ were 
INTROD, were, in the eyes of him or her who are thus divefted of it, a defirable CHA P. XVI, thing, is wrongful. 5. Wrongful inveftment of filiation: (the filiation being confidered as a beneficial thing.) This coincides with impofition of parentality, which, if in the eyes of the pretended father or mother the parentality fhould be an undefirable thing, will be wrongful. 6. Wrongful abdication of filiation. This neceffarily coincides with wrongful diveftment of parentality; it alfo is apt to involve in it wrongful impofition of parentality; though not neceffarily either to. the advantage or to the prejudice of any certain perfon. For if a man, fuppofed at firft to be your fon, appears afterwards not to be your's, it is certain indeed that he is the fon of fome other man, but it may not appear who that other man is. 7. Wrongful detrectation of filiation. This coincides with wrongful non-inveftment or wrongful interception of parentality. 8. Wrongful impofition of filiation. This, if it be the offence of the pretended parent, coincides neceffarily with ufurpation of parentality: if it be the offence of a third perfon, it neceffarily involves impofition of parentality; as alfo divertment of parentality: either or both of which, according to the circumftance above-mentioned, may or may not be, wrongful. 9. Mifmanagement of parental guardianfhip. 10. Defertion of parental guardianfhip. I I. Diffipation in prejudice of filial wardhip. 12. Peculation in prejudice of filial wardihip. 13. Abufe of parental power. 14. Difturbance of parental guardianhip. 15. Breach of duty to parents. 16. Elopement from parents. 17. Child-ftealing. 18. Bribery in prejudice of parental guardianhip.

\section{LI.}

Condition of We fhall now be able to apply ourfelves with fome advantage to the Powers, du- examination of the feveral offences to which the marital condition, or ties, and rights, that may be annexed to it. condition of a hufband, ftands expofed. A hurband is a man, between whom and a certain woman, who in this cafe is called his wife, there fubfifts a legal obligation for the purpofe of their living together, and in particular for the purpofe of a fexual intercourfe to be carried on between them. This obligation will naturally be confidered in four points of view : 1. In refpect of its commencement. 2. In refpect of the placing of it. 3. In refpect of the nature of it. 4. In refpect of 
its duration. Firft then, it is evident, that in point of poffibility, one INTROD. method of commencement is as conceiveable as another: the time of CHAP.XVI. its commencement might have been marked by one fort of event (by one fort of fignal, as it may here be called) as well as by another. But in practice the fignal ufually has been, as in point of utility it conftantly ought to be, a contract entered into by the parties: that is, a fet of figns, pitched upon by the law, as expreffive of their mutual confent, to take upon them this condition. Secondly, and thirdly, with regard to the placing of the obligations which are the refult of the contract, it is evident that they muft reft either folely on one fide, or mutually on both. On the firft fuppofition, the condition is not to be diftinguifhed from pure lavery. In this cafe, either the wife muft be the nave of the hufband, or the hurband of the wife. The firt of thefe fuppofitions has perhaps never been exemplified; the oppoling influence of phyfical caufes being too univerfal to have ever been furmounted: the latter feems to have been exemplified but too often; perhaps among the firft Romans; at any rate, in many barbarous nations. Thirdly, With regard to the nature of the obligations. If they are not fuffered to reft all on one fide, certain rights are thereby given to the other. There muft, therefore, be rights on both fides. Now, where there are mutual rights poffeffed by two perfons, as againft each other, either there are powers annexed to thofe rights, or not. But the perfons in queftion are, by the fuppofition, to live together: in which cafe we have hewn *, that it is not only expedient, but in a manner neceffary, that on one fide there fhould be powers. Now it is only on one fide that powers can be : for fuppofe them on both fides, and they deftroy one another. The question is then, In which of the parties thefe powers fhall be lodged? we have hewn, that on the principle of utility they ought to be lodged in the hufband. The powers then which fubfift being lodged in the hurband, the next queftion is, Shall. the intereft of one party only, or of both, be confulted in the exercife of them ? it is evident, that on the principle of utility the interefts of both ought alike to be confulted: fince in two perfons, taken to-

* Supra, xl. note.

gether, 
INTROD. gether, more happinefs is producible than in one. This being the cafe, CHAP.XVI. it is manifert, that the legal relation which the hurband will bear to the wife will be a complex one: compounded of that of mafter and that of guardian.

LII.

Offences touching the a hulband.
The offences then to which the condition of a hufband will be expofed, will be the fum of thofe to which the two conditions of mafter and guardian are expofed. Thus far the condition of a huband, with refpect to the general outlines of it, ftands upon the fame footing as that of a parent. But there are certain reciprocal fervices, which being the main fubject of the matrimonial contraet, conftitute the effence of the two matrimonial relations, and which neither a mafter nor guardian, as fuch, nor a parent, at any rate, have ufually been permitted to receive. Thefe mut of courfe have been diftinguinhed from the indifcriminate train of fervices at large which the hurband in his character of mafter is impowered to exact, and of thofe which in his character of guardian he is bound to render. Being thus diftinguifhed, the offences relative to the two conditions have, in many inftances, in as far as they have reference to thefe peculiar fervices, acquired particular denominations. In the firt place, with regard to the contract, from the celebration of which the legal condition dates its exiftence. It is obvious that in point of poffibility, this contract might, on the part of either fex, fubfift with refpect to feveral perfons of the other fex at the fame time: the hufband might have any number of wives: the wife might have any number of hurbands: the hurband might enter into the contract with a number of wives at the fame time: or, if with only one at a time, he might referve to himfelf a right of engaging in a fimilar contract with any number, or with only fuch or fuch a number, of other women afterwards, during the continuance of each former contract. This latter accordingly is the footing upon which, as is well known, marriage is and has been eftablifhed in many extenfive countries: particulariy in all thofe which profefs the Mahometan religion. In point of poffibility, it is evident that the like liberty might be referved on the part of the wife : though in point of practice no examples of fuch an arrangement feem ever to 


\section{[D I V I S I O N] of offences.}

cclxxix

have occurred. Which of all thefe arrangements is in point of uti- INTROD. lity the moft expedient, is a queftion which it would require too much Crap.XVI. difcuffion to anfwer in the courfe of an analytical procefs like the prefent, and which belongs indeed to the civil branch of legillation, rather than to the penal *. In Chriftian countries, the folemnization of any fuch contract is made to exclude the folemnization of any fubfequent one during the continuance of a former: and the folemnization of any fuch fubfequent contract is accordingly treated as an offence, under the name of Polygamy. Polygamy then is at any rate, on the part of the man, a particular modification of that offence which may be ftiled ufurpation of the condition of a hufband. As to its other effects, they will be different, according as it was the man only, or the woman only, or both, that were in a ftate of matrimony at the time of the commiffion of the offence. If the man only, then his offence involves in it pro tanto that of wrongful diveftment of the condition of a wife, in prejudice of his prior wife ${ }^{k}$. If the woman only, then it involves in it pro tanto that of wrongful diveftment of the condition of a huband, in prejudice of her prior hufband. If both were already married, it of "courfe involves both the wrongful diveftments which have juft been mentioned. And on the other hand alfo, the converfe of all this may be obferved with regard to polygamy on the part of the woman. Secondly, As the engaging not to enter into any fubfequent engagement of the like kind during the conrinuance of the firft, is one of the conditions on which the law lends its fanction to the firft; fo another is, the inferting as one of the articles of this engagement, an undertaking not to render to, or accept from, any other perfon the fervices which form the characteriftic object of it: the rendering or acceptance of any fuch fervices is accordingly treated as an offence, under the name of adultery: under which name is alfo comprifed the offence of the ftranger; who, in the

* In this cafe alfo, if the woman knew not of the prior marriage, it is befides a fpecies of feduction; and, in as far as it affeets her, belongs to another divifion of the offences of this clafs. Vide fupra, xxxvi.

- See ch, xvii. [Limits] $\$$ iv.

commiffion 
INTROD. commiffion of the above offence, is the neceffary accomplice. Thirdly, Chap. XVI. difturbing either of the parties to this engagement, in the pofferfion of thefe characteriftic fervices, may, in like manner, be diftinguifhed from the offence of difturbing them in the enjoyment of the mifcellaneous advantages derivable from the fame condition; and on whichever fide the blame refts, whether that of the party, or that of a third perfon, may be termed wrongful witbholding of connubial fervices. And thus we have one-and-twenty forts of offences to which, as the law ftands at prefent in Chriftian countries, the condition of a hufband ftands expofed : viz. I. Wrongful non-inveftment of the condition of a hufband. 2. Wrongful interception of the condition of a huband. 3. Wrongful diveftment of the condition of a husband. 4. Ufurpation of the condition of a hufband. 5. Polygamy. 6. Wrongful inveftment of the condition of a hubband. 7. Wrongful abdication of the condition of a hurband. 8. Wrongful detrectation of the condition of a hufband. 9. Wrongful impofition of the condition of a hufband. 10. Mifmanagement of marital guardianfhip. I. Defertion of marital guardianthip. 12. Diflipation in prejudice of matrimonial wardthip. 13. Peculation in prejudice of matrimonial wardhip. 14. Abufe of marital power. I 5 . Difturbance of marital guardianfhip. 16. Wrongful withholding of connubial fervices. 17. Adultery. 18. Breach of duty to hurbands. I 9 . Elopement from hufbands. 20. Wife-ftealing. 21. Bribery in prejudice of marital guardianfhip '.

\section{LIII.}

Offences

Next with regard to the offences to which the condition of a wife ftands expofed. From the patterns that have been exhibited already, the coincidences and affociations that take place between the offences that concern the exiftence of this condition and thofe which concern the exiftence of the condition of a hurband, may eafily enough be apprehended without farther repetitions. The catalogue of thofe

1. SEMI-PUBLIC offences, - Falhoods contefting, or offences againft juftice deftroying, the validity of the marriages of people of certain defcriptions : fuch as Jews, Quakers, Hugonots, \&c. \&c.

1I. SELF-REGARDING offences.-Improvident marriage on the part of minors. 
now under confideration will be precifely the fame in every article as the catalogue laft exhibited.

\section{LIV.}

Thus much for the feveral forts of offences relative to the feveral forts of domeftic conditions : thofe which are conftituted by fuch natural relations as are contiguous being included. There remain thofe which are uncontiguous : of which, after fo much as has been faid of the others, it will naturally be expected that fome notice fhould be taken. Thefe, however, do not afford any of that matter which is neceffary to conftitute a condition. In point of fact, no power feems ever to be annexed to any of them. A grandfather, perhaps, may be called by the law to take upon him the guardianhip of his orphan grandfon : but then the power he has belongs to him not as grandfather, but as guardian. In point of polfibility, indeed, power might be annexed to thefe relations, juft as it might to any other. But ftill no new fort of domeftic condition would refult from it: fince it has been thewn that there can be no others, that, being conftituted by power, thall be diftinct from thofe which have been already mentioned. Such as they are, however, they have this in common with the before-mentioned relations, that they are capable of importing either benefit or burthen : they therefore ftand expofed to the feveral offences whereby thofe or any other selations are liable to be affected in point of exiftence. It might be expected, therefore, that in virtue of thefe offences, they fhould be added to the lift of the relations which are liable to be objects of delinquency. But the fact is, that they already ftand included in that liff: and although not exprefsly named, yet as effectually as if they were. On the one hand, it is only by affecting fuch or fuch a contiguous relation that any offence affecting uncontiguous relations can take place. On the other hand, nither can any offence affecting the exiftence of the contiguous relations be committed, without affecting the exiftence of an indefinite multitude of fuch as are uncontiguous. A falfe witnefs comes, and caufes it to be believed that you are the fon of a woman, who, in truth, is not your mother. What follows? An endlefs tribe of other falfe perfuafionsthat you are the grandfon of the father and of the mother of this

VOL. .

Oo

fuppofed 
INTROD. fuppofed mother: that you are the fon of fome hurband of her's, CHAP.XVI. or, at leaft, of fome man with whom the has cohabited: the grandfon of his father and his mother; and fo on : the brother of their other children, if they have any: the brother-in-law of the hurbands and wives of thofe children, if married: the uncle of the children of thofe children : and fo on.-On the other hand, that you are not the fon of your real mother, nor of your real father: that you are not the grandfon of either of your real grandfathers or grandmothers; and fo on without end : all which perfuafions refult from, and are included in, the one original falfe perfuafion of your being the fon of this your pretended mother.

It hould feem, therefore, at firft fight, that none of the offences againt thefe uncontiguous relations could ever come exprefsly into queltion: for by the fame rule that one ought, fo it might feem ought a thoufand others: the offences againt the uncontiguous being merged as it were in thofe which affect the contiguous relations. So far, however, is this from being the cafe, that in fpeaking of an offence of this ftamp, it is not uncommon to hear a great deal faid of this or that uncontiguous relationfhip which it affects, at the fame time that no notice at all fhall be taken of any of thofe which are contiguous. How happens this? Becaufe, to the uncontiguous relation are annexed perhaps certain remarkable advantages or difadvantages, while to all the intermediate relations none fhall be annexed which are in comparifon worth noticing. Suppofe Antony or Lepidus to have contefted the relationhip of Octavius (afterwards Auguftus) to Caius Julius Cæfar. How could it have been done? It could only have been by contefting, either Octavius's being the fon of Atia, or Atia's being the daughter of Julia, or Julia's being the daughter of Lucius Julius Cærar, or Lucius Julius Cæfar's being the father of Caius. But to have been the fon of Atia, or the grandfon of Julia, or the great grandfon of Lucius Julius Cæfar, was, in comparifon, of fmall importance. Thofe intervening relationhips were, comparatively fpeaking, of no other ufe to him than in virtue of their being fo many neceffary links in the genealogical chain which connected him with the fovereign of the empire.

As to the advantages and difadvantage which may happen to be annexed 


\section{[D I V I S I O N] of offences.}

cclxxxiii

annexed to any of thofe uncontiguous relationfhips, we have feen al- INTROD. ready that no powers over the correlative perfon, nor any correfpond- CHAP.XVI. ing obligations, are of the number. Of what nature then can they be? They are, in truth, no other than what are the refult either of local and accidental inftitutions, or of fome fpontaneous bias that has been taken by the: moral fanction. It would, therefore, be to little purpofe to attempt tracing them out a priori by any exhauttive procefs : all that can be done is, to pick up and lay together fome of the principal articles in each catalogue by way of fpecimen. The advantages which a given relationfhip is apt to impart, feem to be referable chiefly to the following heads: 1 . Chance of fucceffion to the property, or a part of the property, of the correlative perfon. 2. Chance of pecuniary fupport, to be yielded by the correlative perfon, either by appointment of law, or by fpontaneous donation. 3. Acceffion of legal rank; including any legal privileges which may happen to be annexed to it: fuch as capacity of holding fuch and fuch beneficial offices; exemption from fuch and fuch burthenfome obligations; for inftance, paying taxes, ferving burthenfome offices, \&c. \&c. 4. Acceflion of rank by courtefy ; including the fort of reputation which is cuftomarily and fpontaneoufy annexed to diftinguifhed birth and family alliance : whereon may depend the chance of advancement in the way of marriage, or in a thoufand other ways lefs obvious. The difadvantages which a given rekation is liable to impart, feem to be referable chiefly to the following heads: 1 . Chance of being obliged, either by law, or by force of the moral fanction, to yield pecuniary fupport to the correlative party. 2. Lofs of legal rank: including the legal difabilities, as well as the burthenfome obligations, which the law is apt to annex, fometimes with injuftice enough, to the lower ftations. 3. Lofs of rank by courtefy : including the lofs of the advantages annexed by cuftom to fuch rank. 4. Incapacity of contracting matrimony with the correlative perfon, where the fuppofed confanguinity or affinity lies within the prohibited degrees ${ }^{m}$.

LV. We

In purfuance of the plan adopted with relation to femi-public and felf-regarding

002 offences,


cclxxxiv

INTROD.

CHAP. XVI

Civil conditions.

\section{[D I V I S I O N] of offencos.}

\section{LV.}

We come now to civil conditions : thefe, it may well be imagined, may be infinitely various : as various as the atts which a man may be

either

offences, it may bere be proper to exhibit fuch a catalogue as the nature of the defign will admit, of the feveral zenera or inferior divifions of public offences.

I. OFFENCzs againft the external SECURaty of the ftate. 1. Treafon (in favour of foreign enemies.) It may be pofitive or negative (negative confrfting, for example, in the not oppofing the commiffion of pofitive.) 2. Espionage (in favour of foreign rivals not yet enemies) 3. Injuries to foreigners at large (including piracy.) 4. Injuries to privileged foreigners (fuch as ambaffadors.)

II. OfFENCES AGAINST Justice. 1. Offences againft judicial truft: viz. Wrongful non-inveftment of judicial truft, wrongful interception of judicial truft, wrongful diveftment of judicial truft, ufurpation of judicial truft, wrongful inveltment of judicial truft, wrongful abdication of judicial truft, wrongful detrectation of judicial truft, wrongfial impofition of judicial truft, breach of judicial truft, abufe of judicial truft, difturbance of judicial truft, and bribery in prejudice of judicial truft.

Breach and abufe of judicial truft may be either intentional or unintentional. Intentional is culpable at any rate. Unintentional will proceed either from inadvertence, or from mif-fuppofal : if the inadvertence be coupled with heedlefinefs, or the miffuppofal with rafhnefs, it is culpable : if not, blamelefs. For the particular acts by which the exercife of judicial truft may be difurbed, fee B. i. tit. [Offences againit juftice.] They are too multifarious, and too ill-provided with names, to be exhibited here.

If a man fails in fulfilling the duties of this truft, and thereby comes either to break or to abufe it, it muft be through fome deficiency in the three requifite and only requifite endowments, of knowledge, inclination, and power. See fupra, xxvii. p. ccxxxvii. A deficiency in any of thofe points, if any perfon be in fault, may proceed either from his own fault, or from the fault of thofe who thould act with or under him. If perfons who are in fault are perfons invefted with judicial truft, the offence comes under the head of breach or abufe of truft: if other perfons, under that of difturbance of truft.

The ill effects of any breach, abufe, or difturbance of judicial truft, will confift in the production of fome article or articles in the lift of the mifchiefs which it ought to be the original purpofe of judicial procedure to remedy or avert, and of thofe which it ought to be the incidental purpofe of it to avoid producing. Thefe are either primary (that is immediate) or remote: remote are of the $2 \mathrm{~d}, 3^{\mathrm{d}}$, or $4^{\text {th }}$ order, and fo on. The primary are thofe which inport actual pain to perfons affignable, and are therefore mifchievous in themfelves: the fecondary are mifchievous on account of the tendency they have to produce fome article or articles in the catalogue of thofe of the firt order; and are therefore mifchievous in their effects. Thofe of the $3^{d}$ order are mifchievous only on account of the connection they have in the way of productive tendency, as before, with thofe of the $2 \mathrm{~d}$ order: and fo on.

Primary inconveniences, which it ought to be the object of procedure to provide againh, 
either commanded or allowed, whether for his own benefit, or that of INTRoD. others, to abftain from or to perform. As many different denomina- $\mathbf{C}_{\mathbf{H A P}} \mathbf{X V \mathbf { X }}$. tions as there are of perfons diftinguimed with a view to fuch commands and allowances (thofe denominations only excepted which relate to the conditions above fpoken of under the name of domentic ones) fo many civil conditions one might enumerate. Means however, more or lefs explicit, may be found out of circumfcribing their infinitude.

What the materials are, if fo they may be called, of which conditions,

are, 1. The continuance of the individual offence itfelf, and thereby the encreafe as well as continuance of the mifchief of it. 2. The continuance of the whole mifchief of the individual offence. 3. The continuance of a part of the mirchief of the individual offence. 4. Total want of amends on the part of perfons injured by the offence. 5. Partial want of amends on the part of perfons injured by the offence. 6. Superfluous punihment of delinquents. 7. Unjuft punithment of perfons accufed. 8. Unneceffary labour, expence, or other fuffering or danger, on the part of fuperior judicial officers. 9. Unneceflary labour, expence, or other fuffering or danger, on the part of minifterial or other fubordinate judicial officers. ro. Unneceffary labour, expence, or other fuffering or danger, on the part of perfons whofe co-operation is requifite pro re natá, in order to make up the neceffary complement of knowledge and power on the part of judicial officers, who are fuch by profeffion. 11. Unneceffary 1abour, expence, or other fuffering or danger, on the part of perfons at large, coming under the fphere of the operations of the perfons above-mentioned.

Secondary inconveniences are, in the confultative, pre-interpretative (or purely civil) branch of procedure, 1. Mif-interpretation, cr adjudication. In the executive (including the penal) branch, 2. Total impunity of delinquents : (as favouring the production of other offences of the like nature.) 3. Partial impunity of delinquents. 4a Application of punifhment improper in fpecie, though perhaps not in degree (this leffening the beneficial efficacy of the quantity employed.) 5. Unœeconomical application of puninment, though proper, perhaps, as well in fpecie as in degree. 6. Unneceflary pecuniary expence on the part of the ftate.

Inconveniences of the $3 \mathrm{~d}$ order are, 1 . Unneceffary delay. 2. Unneceffary intricacy.

Inconveniences of the $4^{\text {th }}$ order are, 1. Breach, 2. Abufe, 3. Difturbance, of judicial truft, as above : viz. in as far as thefe offences are preliminary to and diftinct from thofe of the $2 \mathrm{~d}$ and $3 \mathrm{~d}$ orders.

Irconveniences of the $5^{\text {th }}$ order are, Breach of the feveral regulations of procedure, or other regulations, made in the view of obviating the inconveniences above enumerated: viz. if preliminary and diftinct, as before.

iII. ORTEnces 
INTROD. tions, or any other kind of legal poffefion, can be made up, we have alCuap. XVI. ready feen: beneficial powers, fiduciary powers, beneficial rights,

I11. OfFENCES againt the PREVENTIVE branch of the Police. 1. Offences againit phtbano-paranomic truft: ( $\varphi \vartheta_{\alpha y \omega}$, to prevent; $\pi \alpha_{\xi} \alpha v_{0} \mu s \alpha$, an offence.) 2. Of-

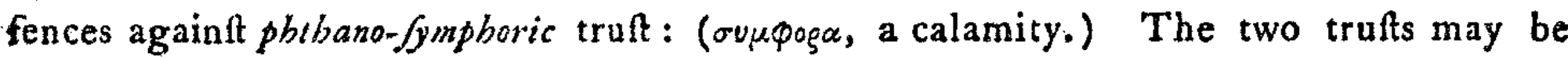

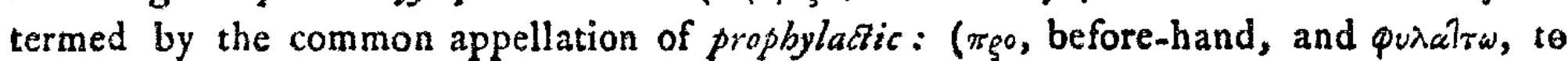
guard again $t$.)

IV. OFFENCEs againft the PUBLIC FORCE. 1. Offences againft military truf, correfponding to thofe againft judicial truf. Military defertion is a breach of military duty, or of military truft. Favouring defertion is a difturbance of it. 2. Offences againft that branch of public truft which confifts in the management of the feveral forts of things appropriated to the purpofes of war: fuch as arfenals, fortifications, dock-yards, thips of war, artillery, ammunition, military magazines, and fo forth.

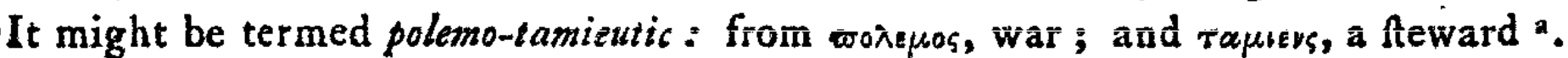

V. OFFENCEs againft the positive ENCREASE of the NATIONAL FBLICITY.

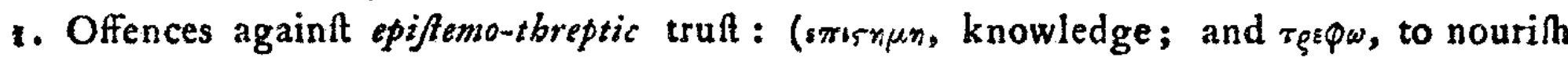
or promore.) 2. Offences againit eupacdagogic truft: $\varepsilon v$, well; and waidarwysw, to edu-

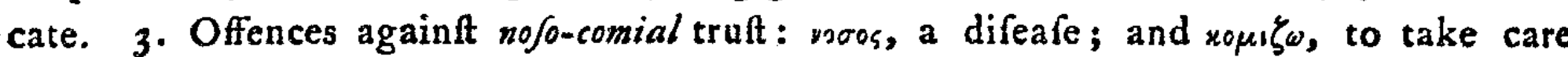
of. 4. Offences againft moro-comial truft: ( $\mu$ wgos, an infane perfon.) 5 . Offences

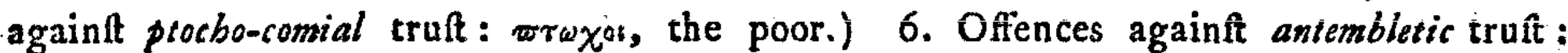
( $\alpha \tau \tau \varepsilon \mu \beta \approx \lambda \lambda \omega$, to beftow in reparation of a lofs.) 7. Offences againft bedonarcbic truft: (ndoyar, pleafures; and aøxorai, to prefide over.) The above are examples of the principal eftablihments which thould or might be fet on foot for the purpofe of making, in fo many different ways, a pofitive addition to the ftock of national felicity. To exhibit an exhauftic analyfis of the poffible total of thefe eftablifhments would not be a very eafy tàlk : nor on the prefent occafion is it a neceffary one : for be they of what nature and in what number they may, the offences to which they ftand expofed will, in as far as they are offences againft truft, be in point of denomination the fame: and as to what turns upon the particular nature of each truft, they will be of too local a nature to come within the prefent plan.

All thefe trufts might be comprized under fome fuch general name as that of agon tbo-poientic truft: (ayavorosse, to do good to any one.)

VI. Opfences againft the PUBLIC WEALTh. 1. Non-payment of forfeitures. 2. Non-payment of taxes, including fmuggling. 3. Breach of the feveral regulations made to prevent the evafion of taxes. 4. Offences againt fifcal truft : the fame as of-

a number of different branches of public truft, none of which have yet been provided with appellatives, have here been brought to view : which then were beft ? to coin new names for them out of the Greek; or, inftead of a word, to make ufe of a whole fentence? In Englifh, and in French, there is no other atsernative; no more than in any of the other fouthera languages. It refts with the reader to determine. 


\section{[D I V I S I O N] of offences.}

fiduriary rights, relative duties, abfolute duties. But as many con- INTROD. ditions as import a power or right of the fiduciary kind, as poffeffed

fences again judicial and military trufts. Offences againt the original revenue, not accruing either from taxes or forfeitures, fuch as that arifing from the public demefnes, Atand upon the fame footing as offences againft private property. 5. Offences againt

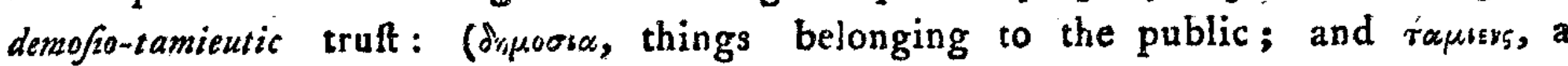
fteward.) viz. againft that truft, of which the object is to apply to their feveral deftinations fuch articles of the public wealth as are provided for the indifcriminate accommodation of individuals : fuch as public roads and waters, public harbours, poftoffices, and packet-boats, and the ftock belonging to them; market-places, and other fuch public buildings; race-grounds, public walks, and fo forth. Offences of this defcription will be apt to coincide with offences againft agatho-poieutic truft as above, or with offences againf ethno-plutific truft hereafter mentioned, according as the benefit in queltion is confidered in itfelf, or as refulting from the application of fuch or fuch a branch or portion of the public wealth.

VIr. OrFences againft populatron. 1. Emigration. 2. Suicide. 3. Procurement of impotence or barrennels. 4. Abortion. 5. Unprolific coition. 6. Celibacy.

Vili. Offelices againt the natronal wealth. 1. Idlenefs. 2. Breach of the regulations made in the view of preventing the application of induftry to purpofes lefs profitable, in prejurdice of purpofes more profitable. 3. Offences againft etbno-plutific

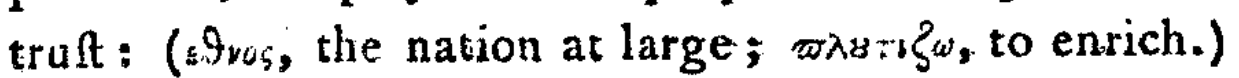

IX. OFFences againft the soverergntr. 3. Offences againft fovereign truft: correfponding to thofe againft judicial, prophylactic, milisary, and fifcal trufts. Offenfive rebellion includes wrongtul interception, wrongful diveftment, ufurpation, and wrongful inveftment, of fovertign truft, with the offences acceffary thereto. Where the traft is in a fingle perfon, wrongful interception, wrongful diveftant, ufurpation, and wrongful inveftment, cannot, any of them, be committed $w$ thout rebellion : abdication and detrectation can never be deemed wrongful : breach and abufe of fovereign truft can fcarcely be punithed : no more can bribe-taking: wrongful impofition of it is fcarce practicable. When the fovereignty is thared among a number, wrongful interception, wrongful diveftment, ufurpation, and wrongful inveftment, may be committed without rebellion: none of the offences againt this truft are impracticable: nor are there any of them but might be punihed. Defenfive rebellion is difturbance of this truft. Political tumults, political defamation, and political vilification, are offences acceffory to fuch difturbance.

Sovereign power (which, upon the principle of utility, can never be other than fiduciary) is exercifed either by rule or without rule: in the latter cafe it may be termed autocratic : in the former cafe it is divided into two branches, the legiflative 
INTROD. by the perfon whofe condition is in queftion, belong to the head of Crap. XVI. trufts. The catalogue of the offences to which thefe conditions are expofed, coincides therefore exactly with the catalogue of offences againit truft: under which head they have been confidered in a general poine of view under the head of offences againft truft: and fuch of them as are of a domeftic nature, in a more particular manner in the character of offences againft the feveral domeftic conditions. Conditions conftituted by fuch duties of the relative kind, as have for

and the exccutive $t$. In either cafe, where the defignation of the perfon by whom the power is to be poffeffed, depends not folely upon mere phyfical events, fuch as that of natural fucceflion, but in any fort upon the will of another perfon, the latter poffeffes an invefitive power, or right of inveftiture, with regard to the power in queftion : in like manner may any perfon alfo poffefs a divefitive power. The powers above enumerated, fuch as judicial power, military power, and fo forth, may therefore be exercireable by a man, either directly, propriâ manu; or indirectly, manu alienâ b. Power to be exercifed manu aliená is inveftitive, which may or may not be accompanied by diveftitive. Of fovereign power, whether autocratic, leginative, or executive, the feveral public trufts above-mentioned form fo many fubordinate branches. Any of thefe powers may be placed, either, 1 . in an individual; or, 2 . in a body politic: who may be either fupreme or fubordinate. Subordination on the part of a magiftrate may be eftablihed, 1. by the perfon's being punifhable: 2. by his being removeable: 3 . by the order's being reverfible.

$X$. OfFEnCEs againft RELIGion. 1. Offences tending to weaken the force of the religious fanction: including blafphemy and profanenefs. 2. Offences tending to mifapply the force of the religious fanction : including falfe prophecies, and other precended revelations; alfo herefy, where the doctrine broached is pernicious to the temporal interefts of the community. 3. Offences againft religious trult, where any fich is thought fit to be entablihed.

XI. OFPEnCEs againft the natronal interest in general. 1. Immoral publications. 2. Offences againtt the truft of an ambaffador; or, as it might be termed, prefbettic truft. 3. Offenses againft the trutt of a privy-counfellor; or, as it might be termed, fymbouleutic trutt. 4. In pure or mixed monarchies, prodigality on the part of perfons who are about the perfon of the fovereign, thongh without being invefted with any fpecific truft. 5. Exceffive gaming on the part of the fame perfons. 6. Taking prefents from rival powers without leave.

- In the former cale, the power might be termed in one word, autocbirows ; in the latter, beterocbirons: (urres, 2 man's owg; $\chi$ Eip, a hand; ireges, another's.)

$$
\text { t See ch, xrii. [Limits] iii. }
$$


their counterparts trufts conftituted by fiduciary powers as well as INTROD. sights on the fide of the correlative party, and thofe of a private CHap.XVI: nature, have alfo been already difcuffed under the appellation of domeftic conditions. The fame obfervation may be applied to the conditions contituted by fuch powers of the beneficial kind over perfons as are of a private nature: as alfo to the fubordinate correlative conditions conftituted by the duties correfponding to thofe rights and powers. As to abfolute duties, there is no inftance of a condition thus created, of which the inftitution is upon the principle of utility to be juftified; unlefs the feveral religious conditions of the monattic kind fhould be allowed of as examples. There remain, as the only materials out of which the conditions which yet remain to be confidered can be compofed, conditions confituted by beneficial powers over things; conditions conftituted by beneficial rights to things (that is, rights to powers over things) or by rights to thofe rights, and fo on; ; conditions. conftituted by rights to fervices; and conditions conftituted by the duties correfponding to thofe refpective rights. Our of thefe are to be taken thofe of which the materials are the ingredients of the feveral modifications of property, the feveral conditions of proprietorhip. Thefe are the conditions, if fuch for a moment they may be ftiled, which having but here and there any fpecific names, are not commonly confidered on the footing of conditions : fo that the acts which, if fuch conditions were recognized, might be confidered as offences againft thofe conditions, are not wont to be confidered in any other light than that of offences againft property.

Now the cafe is, as hath been already intimated*, that of thefe civil conditions, thofe which are wont to be confidered under that name, are not diftinguifhed by any uniform and explicit line from thofe of which the materials are wont to be carried to the head of property : a fet of rights thall, in one inftance, be confidered as conftituting an article of property rather than a condition: while, in another inftance, a fet of rights of the fame ftamp is confidered as con-

- Supra, xvii.
Vou. I.
P P
ftituting 
INTROD. ftituting rather a condition than an article of property. This will CHAr.XVI. probably be found to be the cale in all languages: and the ufage is different again in one language from what it is in another. From thefe caufes it feems to be impracticable to fubject the clafs of civil conditions to any exhaultive method: fo that for making a compleat collection of them there feems to be no other expedient than that of fearching the language through for them, and taking them as they come. To exemplify this obfervation, it may be of ufe to lay open the ftructure as it were of two or three of the principal forts or claffes of conditions, comparing them with two or three articles of property which appear to be nearly of the fame complexion: by this means the nature and generation, if one may fo call it, of both thefe claffes of ideal objects may be the more clearly underftood.

The feveral forts of civil conditions that are not fiduciary may all, or at leaft the greater part of them, be comprehended under the head of rank, or that of profefion; the latter word being taken in its moft extenfive fenfe, fo as to include not only what are called the liberal profeffions, but thofe alfo which are exercifed by the feveral forts of traders, artifts, manufacturers, and other perfons of whatfoever fation, who are in the way of making a profit by their labour. Among ranks then, as well as profefions, let us, for the fake of perficuity, take for examples fuch articles as ftand the cleareft from any mixture of either fiduciary or beneficial power. The rank of knighthood is conftituted, how ? by prohibiting all other perfons from performing certain acts, the performance of which is the fymbol of the order; at the fame time that the knight in queftion, and his companions, are permitted: for inftance, to wear a ribbon of a certain colour in a certain manner: to call himfelf by a certain title: to ufe an armorial feal with a certain mark on it. By laying all perfons but the knight under this prohibition, the law fubjects them to a fet of duties : and fince from the difcharge of thefe duties a benefit refults to the perfon in whofe favour they are created, to wit, the benefit of enjoying fuch a thare of extraordinary reputation and refpect as men are wont to yield to a perfon thus diftinguifhed, to difcharge them is to render him a fervice: and the duty being a duty of the negative clafs, a 
duty confifting in the performance of certain acts of the negative INTROD. kind *, the fervice is what may be called a fervice of forbearance. It appears then, that to generate this condition there muft be two forts of fervices: that which is the immediate caufe of it, a fervice of the negative kind, to be rendered by the community at large: that which is the caufe again of this fervice, a fervice of the pofitive kind, to be rendered by the law.

The condition of a profeffional man ftands upon a narrower footing. To contitute this condition there needs nothing more than a permiffion given him on the part of the leginator to perform thofe acts, in the performance of which confifts the exercife of his profeffion: to give or fell his advice or affiftance in matters of law or phyfic: to give or fell his fervices as employed in the executing or overfeeing of a manufacture or piece of work of fuch or fuch a kind : to fell a commodity of fuch or fuch a fort. Here then we fee there is but one fort of fervice requifite; a fervice which may be merely of the negative kind, to be rendered by the law : the fervice of permitting him to exercife his profeffion: a fervice which, if there has been no prohibition laid on before, is rendered by fimply forbearing to prohibit him.

Now the ideal objects, which in the cafes above fpecified are faid to be conferred upon a man by the fervices that are refpectively in queftion, are in both cafes not articles of property but conditions. By fuch a behaviour on the part of the law, as fhall be the reverfe of that whereby they were refpectively produced, a man may be made to forfeit them: and what he is then faid to forfeit is in neither cafe his property, but in one cafe, his rank or dignity: in the other cafe, his trade or his profeflion: and in both cafes, his condition.

Other cafes there are again in which the law, by a procefs of the fame fort with that by which it conftituted the former of the two above-mentioned conditions, confers on him an ideal object, which the laws of language have placed under the head of property. The law permits a man to fell books : that is, all forts of books in general.

- See ch. [Actions] viii. 
INTROD. Thus far all that it has done is to invert him with a condition: and CHAP.XVI. this condition he would equally poffefs, although every body elfe in the world were to fell books likewife. Let the law now take an active part in his favour, and prohibit all other perfons from felling books of a certain defcription, he remaining at liberty to fell them as before. It thereby confers on him a fort of exclufive privilege or monopoly, which is called a copy-rigbt. But by invefting him with this right, it is not faid to invert him with any new fort of condition: what it invefts him with is fpoken of as an article of property; to wit, of that fort of property which is termed incorporeal ${ }^{n}$ : and fo on in the cafe of an engraving, a mechanical engine, a medicine; or, in fhort, of a faleable article of any other fort. Yet when it gave him an exclufive right of wearing a particular fort of ribbon, the object which it was then confidered as conferring on him was, not an article of property but a condition.

By forbearing to fubject you to certain difadvantages, to which it fubjects an alien, the law confers on you the condition of a naturalborn fubject : by fubjecting him to them, it impofes on him the condition of an alien: by conferring on you certain privileges or rights, which it denies to a roturier, the law confers on you the condition of a gentilbomme; by forbearing to confer on him thofe privileges, it impoles on him the condition of a roturier ${ }^{\circ}$. - The rights, out of which the two advantageous conditions here exemplified are both of them as it were compofed, have for their counterpart a fort of fervices of forbearance, rendered, as we have feen, not by private individuals, but by the law itfelf. As to the duties which it creates in rendering you thefe fervices, they are to be confidered as duties impofed by the leginator on the minifters of juftice.

It may be obferved, with regard to the greater part of the conditions

n The reafon probably why an object of the fort here in queftion is referred to the head of property, is, that the chief value of it arifes from its being capable of being made a fource of property in the more ordinary acceptations of the word; that is, of money, confumable commodities, and fo forth.

- The conditions themfelves having nothing that correfponds to them in England, it was neceffary to make ufe of foreign terms. 
here comprifed under the general appellation of civil, that the relations correfponding to thofe by which they are refpectively conftituted, are not provided with appellatives. The relation which has a name, is that which is borne by the party favoured to the party bound : that which is borne by the party bound to the party favoured has not any. This is a circumftance that may help to diftinguifh them from thofe conditions which we have termed domeftic. In the domeftic conditions, if on the one fide the party to whom the power is given is called a mafter; on the other fide, the party over whom that power is given, the party who is the object of that power, is termed a fervant. In the civil conditions this is not the cafe. On the one fide, a man, in virtue of certain fervices of forbearance, which the reft of the community are bound to render him, is denominated a knight of fuch or fuch an order: but on the other fide, thefe fervices do not beftow any particular denomination on the perfons from whom fuch fervices are due. Another man, in virtue of the leginator's rendering that fort of negative fervice which confifts in the not prohibiting him from exercifing a trade, invefts him at his option with the condition of a trader : it accordingly denominates him a farmer, a baker, a weaver, and fo on: but the minifters of the law do not, in virtue of their rendering the man this fort of negative fervice, acquire for themfelves any particular name. Suppofe even that the trade you have the right of exercifing happens to be the object of a monolopy, and that the legiflator, befides rendering you himfelf thofe fervices which you derive from the permiftion he beftows on you, obliges other perfons to render you thofe farther fervices which you receive from their forbearing to follow the fame trade; yet neither do they, in virtue of their being thus bound, acquire any particular name.

After what has been faid of the nature of the feveral forts of civil conditions that have names, the offences to which they are expofed may, without much difficulty, be imagined. Taken by itfelf, every condition which is thus conftituted by a permiffion granted to the poffeffor, is of courfe of a beneficial nature: it is, therefore, expofed to all thofe offences to which the poffeffion of a benefit is expofed. But either on account of a man's being obliged to perfevere when 
INTROD. once engaged in it, or on account of fuch other obligations as may

Crap. XVI. ftand annexed to the poffeffion of it, or on account of the comparative degree of difrepute which may ftand annexed to it by the moral fanction, it may by accident be a burthen: it is on this account liable to ftand expofed to the offences to which, as hath been feen, every thing that partakes of the nature of a burthen ftands expofed. As to any offences which may concern the exercife of the functions belonging to if, if it happens. to have any duties annexed to it, fuch as thofe, for inftance, which are conftituted by regulations touching the exercife of a trade, it will ftand expofed to fo many breaches of duty: and laftly, whatfoever are the functions belonging to it, it will ftand expofed at any rate to difturbance.

In the forming however of the catalogue of thefe offences, exactnefs is of the lefs confequence, inafmuch as an act, if it mould happen not to be comprifed in this catalogue, and yet is in any refpect of a pernicious nature, will be fure to be found in fome other divifion of the fyftem of offences: if a baker fells bad bread for the price of good, it is a kind of fraud upon the buyer; and perhaps an injury of the fimple corporal kind done to the health of an individual, or a neighbourhood: if a clothier fells bad cloth for good at home, it is a fraud; if to foreigners abroad, it may, over and above the fraud put upon the foreign purchafer, have pernicious effects perhaps in the profperity of the trade at home, and become thereby an offence againft the national wealtb. So again with regard to difturbance: if a man be difturbed in the exercife of his trade, the offence will probably be a wrongful interception of the profit he might be prefumed to have been in a way to make by it: and were it even to appear in any cafe that a man exercifed a trade, or what is lefs unlikely, a liberal profeffion, without having profit in his view, the offence will ftill be reducible to the head of fimple injurious reftrainment, or fimple injurious. compulfion. 


\section{LVI.}

A few words, for the purpofe of giving a general view of the method of. General idea divifion here purfued, and of the advantages which it poffeffes, may have of the method divifion here purfued, and of the advantages which it poffeffes, may have here purfued. their ufe. The whole fyftem of offences, we may obferve, is branched out into five claffes. In the three firf, the fubordinate divifions are taken from the fame fource; viz. from the confideration of the different points, in refpect whereof the intereft of an individual is expofed to fuffer. By this uniformity, a confiderable degree of light feems to be thrown upon the whole fyftem: particularly upon the offences that come under the third clafs: objects which have never hitherto been brought into any fort of order. With regard to the fourth clafs, in fettling the precedence between its feveral fubordinate divifions, it feemed moft natural and fatisfactory to place thofe firft, the connection whereof with the welfare of individuals feemed moft obvious and immediate. The mifchievous effects of thofe offences, which tend in an immediate way to deprive individuals of the protection provided for them againft the attacks of one another, and of thofe which tend to bring down upon them the attacks of foreign affailants, feem alike obvious and palpable. The mifchievous quality of fuch as tend to weaken the force that is provided to combat thofe attacks, but particularly the latter, though evident enough, is one link farther off in the chain of caufes and effects. The ill effects of fuch offences as are of differvice only by diminining the particular fund from whence that force is to be extracted, fuch effects, I fay, though indifputable, are ftill more diftant and out of fight. The fame thing may be obferved with regard to fuch as are mifchievous only by affecting the univerfal fund. Offences againft the fovereignty in general would not be mifchievous, if offences of the feveral defcriptions preceding were not mifchievous. Nor in a temporal view are offences againft religion mifchievous, except in as far as, by removing, or weakening, or mifapplying one of the three great incentives to virtue, and checks to vice, they tend to open the door to the feveral milchiefs, which it is the nature of all thofe other offences to produce. As to the fifth clafs, this, as hath already been 
INTROD. obferved, exhibits, at firft view, an irregularity, which however feems; Crap. XVI. to be unavoidable. But this irregularity is prefently corrected, when the analyfis returns back, as it does after a ftep or two, into the path. from which the tyranny of language had forced it a while to deviate.

It was neceffary that it hould have two purpofes. in view : the one, to exhibit, upon a fcale more or lefs minute, a fyftematical enumeration. of the feveral poffible modifications of delinquency, denominated or undenominated; the other, to find places in the lift for fuch names of offences as were in current ufe: for the firt purpofe, nature was to fet the law; for the other, cuftom. Had the nature of the things themfelves been the only guide, every fuch difference in the manner of perpetration, and fuch only, thould have ferved as a ground for a different denomination, as was attended with a difference in point of effect. This however of itfelf would never have been fufficient; for" as on one hand the new language; which it would have been neceffary to invent, would have been uncouth, and in a manner unintelligible; fo on the other hand the names, which were before in current ufe, and which, in fpite of all fyftems, good or bad, muft have remained in. current ufe, would have continued unexplained. To have adhered exclufively to the current language, would have been as bad on the other fide; for in that cafe the catalogue of offences, when compared to that of the mifchiefs that are capable of being produced, would have been altogether broken and uncompleat.

To reconcile thefe two objects, in as far as they feemed to be recon. cileable, the following courfe has therefore been purfued. 'The logical whole, conftituted by the fum total of pofible offences, has been bifected in as many different directions as were neceffary, and the procefs in each. direction carried down to that ftage at which the particular ideas thus divided found names in current ufe in readiners to receive them. At that period I have ftopped; leaving any minuter diftinctions to be enumerated in the body of the work, as fo many fpecies of the genus characterized by fuch or fuch a name. If in the courfe of any fuch procefs I came to a mode of conduct which, though it required to be taken notice of, and perhaps had actually been taken notice of, under all laws, in the character of an offence, had hitherto been expreffed under 
under different laws, by different circumlocutions, without ever having received any name capable of occupying the place of a fubftantive in a fentence, I have frequently ventured fo far as to fabricate a new name for it, fuch an one as the idiom of the language, and the acquaintance I happened to have with it, would admit of. Thefe names confifting in moft inftances, and that unavoidably, of two or three words brought together, in a language too which admits not, like the German and the Greek, of their being meited into one, can never be upon a par, in point of commodioufnefs, with thofe univocal appellatives which make part of the eftablinhed ftock.

In the choice of names in current ufe, care has been taken to avoid all fuch as have been grounded on local diftinctions, ill founded perhaps in the nation in which they received their birth, and at any rate not applicable to the circumftances of other countries.

The analyfis, as far as it goes, is as applicable to the legal concerns of one country as of another: and where, if it had defcended into further details, it would have ceafed to be fo, there I have taken care.always to ftop: and thence it is that it has come to be fo much more particular in the clafs of offences againft individuals, than in any of the other claffes. One ufe then of this arrangement, if it Mhould be found to have been properly conducted, will be its ferving to point out in what it is that the legal interefts of all countries agree, and in what it is that they are liable to differ: how far a rule that is proper for one, will ferve, and how far it will not ferve, for another. That the legal interefts of different ages and countries have nothing in common, and that they have every thing, are fuppofitions equally diftant from the truth ${ }^{\text {P. }}$

\section{LVII.}

A natural method, fuch as it hath been here attempted to exhibit, feems to poffefs four capital advantages; not to mention others of inferior note. In the firft place, it affords fuch affiftance to the appre-

$p$ The above hints are offered to the confideration of the few who may be difpored to bend their minds to difquifitions of this uninviting nature: to fift the matter to the bottom, and engage in the details of illuftration, would require more room than could in this place be confiftently allowed.

Vor. I.

Its advantages. 1.- It is convenient for the apprehenfion and the memory. 
INTROD. henfion and to the memory, as thofe faculties would in vain look for in Crap. XVI. any technical arrangement ${ }^{*}$. That arrangement of the objects of any fcience may, it hould feem, be termed a natural one, which takes fuch properties to characterize them by, as men in general are, by the common conftitution of man's nature, independently of any accidental impreffions they may have received from the influence of any local or other particular caufes, accuftomed to attend to: fuch, in a word, as naturally, that is readily and at firft fight engage, and firmly fix, the attention of any one to whom they have once been pointed out. Now by what other means thould an object engage or fix a man's attention, unlers by interefting him? and what circumftance belonging to any action can: be more interefting, or rather what other circumftance belonging to it can be at all interefting to him, than that of the influence it promifes. to have on his own happinefs, and the happinefs of thofe who are about him? By what other mark then thould he more eafily find the place which any offence occupies in the fyftem, or by what other clue fhould he more readily recall it ?

\section{LVIII.}

-2. It gives room for ge-neral pro-

In the next place, it not only gives at firft glance a general intimapofitions. tion of the nature of each divifion of offences, in as far as that natureis determined by fome one characteriftic property, but it gives room for a number of general propofitions to be formed concerning the particular offences that come under that divifion, in fuch manner as to. exhibit a variety of other properties that may belong to thern in common. It gives room, therefore, for the framing of a number of propofitions concerning them, which, though very general, becaufe predicated of a great number of articles, thall be as generally true 9 .

LIX. In

- Imagine what a condition a fcience muft be in, when as yet there thall be no fuch thing as forming any extenfive propofition relative to it, that thall be at the fame time a true one: where, if the propoftion thall be true of fome of the particulars contained under it, it thall be falfe with regard to others. What a ftate would botany, for example, be in, if the claffes were fo contrived, that no common characters could be fownd for them? Yet in this ftate, and no better, feems every fyftem of penal law to

- See Fragment on Government, pref. p. xlv. 
LIX.

INTROD.

In the third place, it is fo contrived, that the very place which any offence is made to occupy, fuggefts the reafon of its being put there. It ferves to indicate, not only that fuch and fuch acts are made offences, but why they ought to be. By this means, while it addreffes itfelf to CHAP. XVI, the underftanding, it recommends itfelf in fome meafure to the af fections. By the intimation it gives of the nature and tendency of each obnoxious act, it accounts for, and in fome meafure vindicates, the treatment which it may be thought proper to beftow upon that act in the way of punifhment. To the fubject then it is a kind of perpetual apology: Thewing the neceflity of every defalcation, which, for the fecurity and profperity of each individual, it is requifite to make from the liberty of every other. To the leginator it is a kind of perpetual leffon: ferving at once as a corrective to his prejudices, and as a check upon his paffions. Is there a mifchief which has efcaped him? in a natural arrangement, if at the fame time an exhauftive one, he cannot fail to find it. Is he tempted ever to force innocence within the pale of guilt ? the difficulty of finding a place for it advertifes him of his error. Such are the ufes of a map of univerfal delinquency, laid down upon the principle of utility: fuch the advantages, which the leginator as well as the fubject may derive from it. Abide by it, and every thing that is arbitrary in legination, vanifhes. An evil-intentioned or prejudiced leginator durft not look it in the face. He

be, authoritative or unauthoritative, that has ever yet appeared. Try if it be otherwife, for inftance, with the delicta privata $E^{\circ}$ publica, and with the publica ordinaria, and publica extra-ordinaria of the Roman law *. All this for want of method: and hence the neceffity of endeavouring to ftrike out a new one.

Nor is this want of method to be wondered at. A fcience fo new as that of penal legiflation, could hardly have been in any better ftate. Till objects are diftinguilhed, they cannot be arranged. It is thus that trutb and order go on hand in hand. It is only in proportion as the former is difcovered, that the latter can be improved. Before a certain order is eftablifhed, truth can be but imperfectly announced : but until a certain proportion of truth has been developed and brought to light, that order cannot be eftablifhed. The difcovery of truth leads to the eftablifhment of order : and the eftablifhment of order fixes and propagates the difcovery of truth.

- See Heinecc, Elem. p. vii. $\$ 79,80$. 
INTROD. would profcribe it, and with reafon: it would be a fatire on his. ChAP. XVI. laWs.

LX.

-4. It is alike applicable to the
laws of all nations.
In the fourth place, a natural arrangement, governed as it is by $a$ principle which is recognized by all men, "will ferve alike for the jurifprudence of all nations. In a fyftem of propofed law, framed in purfuance of fuch a method, the language will ferve as a gloffary by which all fyftems of pofitive law might be explained, while the matter ferves as a ftandard by which they might be tried. Thus illuf trated, the practice of every nation might be a leffon to every other: and mankind might carry on a mutual interchange of experiences and improvements, as eafily in this as in every other walk of fcience. If any one of thefe objects thould in any degree be attained, the law bour of this analyfis, fevere as it has been, will not have been thrown away.

\section{\$5. Characters of the five clafes.}

\section{LXXI.}

Characters of It has been mentioned * as an advantage poffeffed by this methe claffes,
how deduci- thod, and not poffeffed by any other, that the objects comprized? ble from the under it are calt into groupes, to which a variety of propofitions may above me- be applied in common. A collection of thefe propofitions, as ap-
thod. plied to the feveral claffes, may be confidered as exhibiting the dif tinctive characters of each clafs. So many of thefe propofitions as can be applied to the offences belonging to any given clafs, fo many properties are they found to have in common: fo many of thefe common properties as may refpectively be attributed to them, fo many properties may be fet down to ferve as characters of the clafs. A collection of thefe characters it may here be proper to exhibit. The more of them we can bring together, the more clearly and fully will the nature of the feveral claffes, and of the offences they are compofed: of, be underftood.

- Supra, lviii. 
Characters of clafS $I$; compofed of PRIVATE offences, or offences againt affignable individuals.

1. When arrived at their laft ftage (the ftage of confummation *) they produce, all of them, a primary mifchief as well as a fecondary + .

2. The individuals whom they affect in the firft inftance ", are conftantly affignable. This extends to all; to attempts and preparations, as well as to fuch as have arrived at the ftage of confummation $\neq$.

3. Confequently they admit of compenfation $V:$ in which they differ from the offences of all the other claffes, as fuch.

4. They adimit alfo of retaliation $\$$; in which alfo they differ from, the offences of all the other claffes.

5. There is always fome perfon who has a natural and peculiar intereft to profecute them. In this they differ from felf-regarding offences: alfo from femi-public and public ones; except in as far as the two latter may chance to involve a private michief.

6. The mifchief they produce is obvious: more fo than that of femi-public offences: and ftill more fo than that of felf-regarding ones, or even public..

7. They are every where, and muft ever be, obnoxious to the cenfure of the world: more fo than femi-public offences as fuch; and ftill more fo than public ones.

8. They are more conftantly obnoxious to the cenfure of the world than felf-regarding offences : and would be fo univerfally, were it not for the influence of the two falfe principles; the principle of afceticifin, and the principle of antipathy ${ }^{* *}$.

[Firft Inftance.] That is, by their primary mirchief.

- [Admit.] I mean, that retaliation is capable of being applied in the cafes in queftion; not that it ought always to be employed. Nor is it capable of being applied in every individual inftance of each offence, but only in fome individual inftance of each Species of offence.

- Ch. vii. [Actions] xiv.. + See ch. xii. [Confequences] iii. $\quad$ See fupra, xxxi. note; and B. I. tit. [Acceffory offences.] II See ch. xiii. [Cafes unmeet] ii. note. See ch. xv. [Properties] viii. * Ch. ii. [Principles adverfe.] 
INTROD. 9. They are lefs apt than femi-public and public offences to require CHap.XVI. different defcriptions ${ }^{t}$ in different ftates and countries: in which refpect they are much upon a par with felf-regarding ones.

10. By certain circumftances of aggravation, they are liable to be transformed into femi-public offences: and by certain others, into public.

II. There can be no ground for puninhing them, until they can be proved to have occafioned, or to be about to occafion, fome particular mifchief to fome particular individual. In this they differ from femipublic offences, and from public.

12. In night cafes, compenfation given to the individual affected by them, may be a fufficient ground for remitting punifhment : for if the primary mifchief has not been fufficient to produce any alarm, the whole of the mifchief may be cured by compenfation. In this alfo they differ from femi-public offences, and from public ones.

\section{LXIII.}

Characters of Characters of clafs 2; compofed of $\overline{S E M} \bar{M}-\bar{P} u \bar{B} \mathrm{Li}$ offences, or offences clafs.2. $\quad$ affecting a whole fubordinate clafs of perfons.

I. As fuch, they produce no primary mifchief. The mifchief they produce confifts of one or other or both branches of the fecondary mifchief produced by offences againtt individuals, without the primary.

2. In as far as they are to be confidered as belonging to this clafs, the perfons whom they affect in the firf inftance are not individually aflignable.

3. They are apt, however, to involve or terminate in fome primary mirchief of the firft order; which when they do, they advance into the firtt clafs; and become private offences.

4. They admit not, as fuch, of compenfation.

5. Nor of retaliation.

'[Different defcriptions.] It feems to be from their poffefing thefe three laft properties, that the cultom has arifen of fpeaking of them, or at leaft of many of them, under the name of offences againft the law of naturs: a vague expreffion, and productive of a multitude of inconveniences, See ch. ii. [Principles adverfe] xiv, note. 
6. As fuch, there is never any one particular individual whofe exclufive intereft it is to profecute them : a circle of perfons may, however, always be marked out, within which may be found fome who have a greater intereft to profecute than any who are out of that circle have.

7. The mifchief they produce is in general pretty obvious : not fo much fo indeed as that of private offences; but more fo upon the whole than that of felf-regarding and public ones.

8. They are rather lefs obnoxious to the cenfure of the world than private offences; but they are more fo than public ones: they would alfo be more fo than felf-regarding ones, were it not for the influence of the two falfe principles, the principle of fympathy and antipathy, and that of afceticifm.

9. They are more apt than private and felf-regarding offences to require different defcriptions in different countries : but lefs fo than public ones.

10. There may be ground for punifhing them before they have been proved to have occafioned, or to be about to occafion, mifchief to any particular individual; which is not the cafe with private offences.

II. In no cafes can fatisfaction given to any particular individual affected by them be a fufficient ground for remitting punifhment: for by fuch fatisfaction it is but a part of the mifchief of them that is cured.: In this they differ from private offences; but agree with public.

\section{LXIV.}

Characters of clafs 3 ; confifting of SELF-REGARDing offences: Charactere offences againft one's Self.

x. In individual inftances it will of ten be queftionable, whether they are productive of any primary" mifchief at all : fecondary, they produce none.

2. They affect not any other individuals, affignable or not affignable, except in as far as they affect the offender himfelf; unlefs by poffibility

"Becaufe the perfon, who in general is molt likely to be fenfible to the mifchief (if there is any) of any offence, viz, the perfon whom it moft affects, thews by his conduct that he is not fenfible of it. 
INTROD. in particular cafes; and in a very light and diftant manner the whole Crap. XVI. Atate.

3. They admit not, therefore, of compenfation.

4. Nor of retaliation.

5. No perfon has naturally any peculiar intereft to profecute them: except in as far as in virtue of fome connection he may have with the offender, either in point of fympatby or of intereft ${ }^{*}$, a mifchief of the derivative kind t may happen to devolve upon him ${ }^{*}$.

6. The mifchief they produce is apt to be unobvious, and in general more queftionable than that of any of the other claffes ${ }^{y}$.

7. They are however apt, many of them, to be more obnoxious to the cenfure of the world than public offences; owing to the influence of the two falfe principles; the principle of afceticifm, and the principle of antipathy. Some of them more even than femi-public or even than private offences.

8. They are lefs apt than offences of any other clafs to require different defcriptions in different ftates and countries ${ }^{x}$.

9. Among the inducements ${ }^{*}$ to punifh them, antipathy againtt the offender is apt to have a greater thare than fympathy for the public.

10. The beft plea for punifhing them is founded on a faint probability there may be of their being productive of a mifchief, which, if real, will place them in the clafs of public ones: chiefly in thofe divifions of it which are compofed of offences againt population, and offences againt the national wealth,

- Among the offences, however, which belong to this clafs, there are fome which in certain countries it is not uncommon for perfons to be difpofed to profecute without any artificial inducement, and merely on account of an axtipatby, which fuch acts are apt to excite. See ch. ii. [Principles adverfe] xi.

See note ${ }^{u}$ in the preceding page.

- Accordingly, moft of them are apt to be ranked among offences againft the law of nature. Vide fupra, Characters of the Ift clafs, 1xii, note.

- [Inducements.] I mean the confiderations, right or wrong, which induce or difpore the legiffator to treat them on the footing of offences.

See ch, vi. [Senfibility] xxv. xxvi. † See ch. xii. [Confequences] iv. 
LXXV.

Characters of Clafs 4 ; confifting of PuBLIC offences, or offences againft the ftate in general.

I. As fuch, they produce not any primary mifchief; and the fecondary mifchief they produce, which confifts frequently of danger without alarm, though great in value, is in specie very indeterminate.

2. The individuals whom they affect, in the firft inftance, are conftantly unaffignable; except in as far as by accident they happen to involve or terminate in fuch or fuch offences againft individuals.

3. Confequently they admit not of compenfation.

4. Nor of retaliation.

5. Nor is there any perfon who has naturally any particular intereft to profecute them; except in as far as they appear to affect the power, or in any other manner the private intereft, of fome perfon in authority.

6. The mifchief they prodưce, as fuch, is comparatively unobvious; much more fo than that of private offences, and more fo likewife, than that of femi-public ones.

7. They are, as fuch, much lefs obnoxious to the cenfure of the world, than private offences; lefs even than femi-public, or even than felfregarding offences; unlefs in particular cafes, through fympathy to certain perfons in authority, whofe private interefts they may appear to affect.

8. They are more apt than any of the other claffes to admit of different defcriptions, in different ftates and countries.

9. They are contituted, in many cafes, by fome circumftances of aggravation fuperadded to a private offence: and therefore, in thefe cafes, involve the mifchief, and exhibit the other characters, belonging to both claffes. They are, however, even in fuch cafes, properly enough ranked in the $4^{\text {th }}$ clafs, inafmuch as the mifchief they produce in virtue of the properties which aggregate them to that clafs, eclipfes and fwallows up that which they produce in virtue of thofe properties which aggregate them to the Ift.

10. There may be fufficient ground for punifhing them, without their being proved to have occafioned, or to be about to occafion, any par-

VoL. I. 
INTROD. ticular mifchief to any particular individual. In this they differ from CaAp. XVI. private offences, but agree with femi-public ones. Here, as in femipublic offences, the extent of the mifchief makes up for the uncertainty of it.

11. In no cafe can fatisfaction, given to any particular individual affected by them, be a fufficient ground for remitting punifhment. In this they differ from private offences; but agree with femi-public.

\section{L.XVI.}

Characters of Characters of clafs 5 , or appendix : compofed of MULTIFORM Or ANOMAClafs 5. Lous offences; and containing offences by FALSHOOD, and offences. concerning TRUST.

x. Taken collectively, in the parcels marked our by their popular appellations, they are incapable of being aggregated to any fyftematical method of diftribution, grounded upon the mifchief of the offence.

2. They may, however, be thrown into fub-divifions, which may be aggregated to fuch a method of diftribution.

3. Thefe fub-divifions will naturally and readily rank under the divifions of the feveral preceding claffes of this fyftem.

4. Each of the two great divifions of this clafs fpreads itfelf in that manner over all the preceding claffes.

5. In fome acts of this clafs, the diftinguinhing circumftance which conftitutes the effential character of the offence, will in fome inftances enter neceffarily, in the character of a criminative circumftance, into the conftitution of the offence; infomuch that, without the intervention of this circumftance, no offence at all, of that denomination, can be committed $^{b}$. In other inftances, the offence may fubfift without it; and where it interferes, it comes in as an accidental independent circumftance, capable of conftituting a ground of aggravation :.

- Inftance, offences by falliood, in the cafe of defraudiment.

- Inftance, offences by falthood, in the cafe of fimple corporal injuries, and other ofences againft perfon. 


\section{H A P. XVII.}

\section{Limits between private etbics and the art of legiflation.}

I.

QO much for the divifion of offences in general. Now an offence $S$ is an act prohibited, or (what comes to the fame thing) an act of which the contrary is commanded, by the law : and what is it that the law can be employed in doing, befides prohibiting and commanding?

INTROD. CH. XVII. Ufe of this chapter. It fhould feem then, according to this view of the matter, that were we to have fettled what may be proper to be done with relation to offences, we hould thereby have fettled every thing that may be proper to be done in the way of law. Yet that branch which concerns the method of dealing with offences, and which is termed fometimes the criminal, fometimes the penal, branch, is univerfally underftood to be but one out of two branches which compofe the whole fubject of the art of legination; that which is termed the civil being the other. Between thefe two branches then, it is evident enough, there cannot but be a very intimate connection; fo intimate is it indeed, that the limits between them are by no means eafy to mark out. The care is the fame in fome degree between the whole bufinefs of legination (civil and penal branches taken together) and that of private ethics. Of thefe feveral limits however it will be in a manner neceffary to exhibit fome idea : left, on the one hand, we thould feem to leave any part of the fubject that does belong to us untouched, or, on the other hand, to deviate on any fide into a track which does not belong to us.

In the courfe of this enquiry, that part of it I mean which concerns the limits between the civil and the penal branch of law, it will be neceffary to fettle a number of points, of which the connection with the main queftion might not at firft fight be fufpected. To afcertain what fort of a thing a law is; what the parts are that are to be found in it; what it muft contain in order to be compleat; what the connection is between that part of a body of laws which belongs to the fub- 


\section{cccviii Of the [L I M I T S] of the penal branch of juripprudence.}

INTROD. ject of procedure and the reft of the law at large:-All thefe, it will $\mathrm{C}_{\text {H. XVII. }}$ be feen, are fo many problems, which mutt be folved before any fatisfactory anfwer can be given to the main queftion above mentioned.

Nor is this their only ufe : for it is evident enough, that the notion of a compleat law mult firft be fixed, before the leginator can in any cafe know what it is he has to do, or when his work is done.

II.

Ethics in ge-

Ethics at large may be defined, the art of directing men's actions to neral, what. the production of the greateft poffible quantity of happinefs, on the part of thofe whofe intereft is in view.

III.

Private What then are the actions. which it can be in a man's power to direct? ethics. They muft be either his own actions, or thofe of other agents. Ethics, in as far as it is the art of directing a man's own actions, may be ftiled the art of felf-government, or private etbics.

IV.

The art of government: that is, of legillation and adminiAration.

Interefts of the infericr animals improperly begillition.
What other agents then are there, which, at the fame time that they are under the influence of man's direction, are fufceptible of happinefs? They are of two forts: 1 . Other human beings who are ftiled. perfons. 2. Other animals, which, on account of their interefts having been neglected by the infenfibility of the ancient jurifts, ftand degraded. into the clafs of tbings ${ }^{2}$. As to ather human beings, the art of direct-.

ing.

a Under the Gentoo and Mahometan religions, the interefts of the reft of the animinal creation feem to have met with fome attention. Why have they not, univerfally, with as much as thofe of human creatures, allowance made for the difference in point of fenfibility? Becaufe the laws that are have been the work of mutual fear; a fentiment which the lefs rational animals have not had the fame means as man has of turning to account. Why ought they not? No reafon can be given. If the being eaten were all, there is very good reafon why we thould be fuffered to eat fuch of them as we like to eat: we are the better for it, and they are never the worfe. They have none of thofe long-protracted anticipations of future mifery which we have. The death they fuffer in our hands commonly is, and always may be, a fpeedier, and by that means a lefs painful one, than that which would await them in the inevitable courfe of nature. If the being killed were all, there is very good reafon why we should be fuffered to kill fuch as moleft us: we thould be the worfe for their living, and they are never the worfe for being dead. But is there any reafon why we fhould be 
ing their actions to the above end is what we mean, or at leaft the only thing which, upon the principle of utility, we ought to mean, by the art of government : which, in as far as the meafures it difplays itfelf in are of a permanent nature, is generally diftinguifhed by the name of legilation: as it is by that of adminiftration, when they are of a temporary nature, determined by the occurrences of the day.

$\mathrm{V}$.

Now human creatures, confidered with refpect to the maturity of Art of edutheir faculties, are either in an adult, or in a non-adult ftate. The art of goverment, in as far as it concerns the direction of the actions of perfons in a non-adult ftate, may be termed the art of education. In as far as this bufinefs is entrufted with thofe who, in virtue of fome private relationfhip, are in the main the beft difpofed to take upon them, and the beft able to difcharge, this office, it may be termed the art of private education: in as far as it is exercifed by thofe whofe province it is to fuperintend the conduet of the whole community, it may be termed the art of public education.

fuffered to torment them? Not any that I can fee. Are there any why we fhould not be fuffered to torment them? Yes, feveral. See B. I. tit. [Cruelty to animals.] The day has been, I grieve to fay in many places it is not yet paft, in which the greater part of the fpecies, under the denomination of naves, have been treated by the law exactly upon the fame footing as, in England for example, the inferior races of animals are ftill. The day may come, when the reft of the animal creation may acquire thore rights which never could have been withholden from them but by the hand of tyranny. The French have already difcovered that the blacknefs of the $\mathbb{k}$ in is no reafon why a human being thould be abandoned without redrefs to the caprice of a tormentor *. It may come one day to be recognized, that the number of the legs, the villofity of the fkin, or the termination of the os facrum, are reafons equally infufficient for abandoning a fenfitive being to the fame fate? What elfe is it that fhould trace the infuperable line $?$ Is it the faculty of reafon, or, perhaps, the faculty of difcourfe? But a full-grown horfe, or dog, is beyond comparifon a more rational, as well as a more converfible animal, than an infant of a day, or a week, or even a month, old. But fuppofe the cafe were otherwife, what would it avail $i$ the queftion is not, Can they reafon? nor, Can they talk? but, Can they Juffer? 
INTROD. $\mathrm{CH}$. XVII.

Ethics exhibits the rules of, 1 . Prudence.

2. Probity.

3. Benefi-

cence.
VI.

As to ethics in general, a man's happinefs will depend, in the firft place, upon fuch parts of his behaviour as none but himfelf are interefted in; in the next place, upon fuch parts of it as may affect the happinefs of thofe about him. In as far as his happinefs depends upen the firft-mentioned part of his behaviour, it is faid to depend upon his duty to bimfelf. Ethics then, in as far as it is the art of directing a man's actions in this refpect, may be termed the art of difcharging one's duty to one's felf: and the quality which a man manifelts by the difcharge of this branch of duty (if duty it is to be called) is that of prudence. In as far as his happinefs, and that of any other perfon or perfons whofe interefts are confidered, depends upon fuch parts of his behaviour as may affect the interefts of thore about him, it may be faid to depend upon his duty to otbers; or, to ufe a phrafe now fomewhat antiquated, his duty to bis neigbbour. Ethics then, in as far as it is the art of directing a man's actions in this refpect, may be termed the art of difcharging one's duty to one's neighbour. Now the happinefs of one's neighbour may be confulted in two ways : I. In a negative way, by forbearing to diminifh it. 2. In a pofitive way, by ftudying to encreafe it. A man's duty to his neighbour is accordingly partly negative and partly pofitive: to difcharge the negative branch of it, is probity: to difcharge the pofitive branch, beneficence.

\section{VII.}

It may here be afked, How it is that upon the principle of private ethics, legination and religion out of the queftion, a man's happinefs depends upon fuch parts of his conduct as affect, immediately at leaft, the happinefs of no one but himfelf : this is as much as to an, What motives (independent of fuch as legination and religion may chance to furnifh) can one man have to confult the happinefs of another? by what motives, or, which comes to the fame thing, by what obligations, can he be bound to obey the dietates of probity and beneficence? In anfwer to this, it cannot but be admitted, that the only interefts which a man at all times and upon all occafions is fure to find adequate motives for confulting, are his own. Notwithftanding this, there are no 
occafions in which a man has not fome motives for confulting the happinefs of other men. In the firft place, he has, on all occafions, the purely INTROD. focial motive of fympathy or benevolence: in the next place, he has, on moft occafions, the femi-focial motives of love of amity and love of reputation. The motive of fympathy will act upon him with more or lefs effect, according to the bias of his fenfibility*: the two other motives, according to a variety of circumftances, principally according to the ftrength of his intellectual powers, the firmnefs and fteadinefs of his mind, the quantum of his moral fenfibility, and the characters of the people he has to deal with.

VIII.

Now private ethics has happinefs for its end : and legination can Every act have no other. Private ethics concerns every member, that is, the happinefs and the actions of every member, of any community that can be propofed; and legination can concern no more. Thus far, then, private ethics and the art of legiflation go hand in hand. The end they have, or ought to have, in view, is of the fame nature. The perfons whofe happinefs they ought to have in view, as alfo the perfons whofe conduct they ought to be occupied in directing, are precifely the fame. The very acts they ought to be converfant about, are even in a great meafure the fame. Where then lies the difference? In that the acts which they ought to be converfant about, though in a great meafure, are not perfectly and tbrougbout the fame. There is no cafe in which a private man ought not to direct his own conduct to the production of his own happinefs, and of that of his fellow-creatures : but there are cafes in which the leginator ought not (in a direct way at leaft, and by means of punifhment applied immediately to particular individual acts) to attempt to direct the conduct of the feveral other: members of the community. Every act which promifes to be beneficial upon the whole to the community (himfelf included) each individual ought to perform of himfelf : but it is not every fuch act that the leginator ought to compel him to perform. Every act which promifes to be pernicious upon the whole to the community (himfelf in-

- Cho. vi. [Senfibility] iii. 
INTROD. cluded) each individual ought to abftain from of himfelf: but it is not Сн. XVII. every fuch act that the leginator ought to compel him to abftain from.

IX.

The limits between the provinces of private ethics and legin?tion, marked out by the cafes unmeet for punilhment.
Where then is the line to be drawn?-We thall not have far to feek for it. The bufinefs is to give an idea of the cafes in which ethics ought, and in which legination ought not (in a direct manner at leaft) to interfere. If leginlation interferes in a direct manner, it muft be by punifhment ${ }^{\circ}$. Now the cafes in which punifhment, meaning the punifhment of the political fanction, ought not to be inflicted, have been already ftated *. If then there be any of thefe cafes in which, although legination ought not, private ethics does or ought to interfere, thefe cafes will ferve to point out the limits between the two arts or branches of icience. Thefe cafes, it may be remembered, are of four forts : 1. Where punifhment would be groundlefs. 2. Where it would be inefficacious. 3. Where it would be unprofitable. 4. Where it would be needlefs. Let us look over all thefe cafes, and fee whether in any of them there is room for the interference of private ethics, at the fame time that there is none for the direct inteference of legillation.

\section{$\mathrm{X}$.}

i. Neither ought to apply where punifiment is groundlefs.

I. Firft then, as to the cafes where punifhment would be groundlefs. In thefe cafes it is evident, that the reftrictive interference of ethics would be groundlefs too. It is becaufe, upon the whole, there is no evil in the act, that legination ought not to endeavour to prevent it. No more, for the fame reafon, ought private ethics.

\section{XI.}

2. How far private ethics can apply in the cafes where panifhment would be inefficacious.

2. As to the cafes in which punifhment would be inefficacious. Thefe, we may obferve, may be divided into two fets or claffes. The firft do not depend at all upon the nature of the act: they turn only upon a defect in the timing of the puninment. The punifhment in quef-

b I fay nothing in this place of reward: becaule it is only in a few extraordinary cafes that it can be applied, and becaufe even where it is applied, it may be doubted, perhaps, whether the application of it can, properly fpeaking, be termed an act of legilation. See infra, $\$ 3$.

- Ch. xiii. [Cafes unmeet.] 
tion is no more than what, for any thing that appears, ought to have been applied to the act in queftion. It ought, however, to have been applied at a different time; viz. not till after it had been properly denounced. Thefe are the cafes of an ex-poft-facto law; of a judicial fentence beyond the law; and of a law not fufficiently promulgated. The acts here in queftion then might, for any thing that appears, come properly under the department even of coercive legination: of courfe do they under that af private ethics. As to the other fet of cafes, in which punifhment would be inefficacious; neither do thefe depend upon the nature of the act, that is, of the fort of act: they turn only upon fome extraneous circumftances, with which an act of any fort may chance to be accompanied. Thefe, however, are of fuch a nature as not only to exclude the application of legal punifhment, but in general to leave little room for the infuence of private ethics. There are the cafes where the will could not be deterred from any act, even by the extraordinary force of artificial punifhment : as in the cafes of extreme infancy, infanity, and perfect intoxication: of courfe, therefore, it could not by fuch flender and precarious force as could be applied by private ethics. The cafe is in this refpect the fame, under the circumitances of unintentionality with refpect to the event of the action, unconfcioufnefs with regard to the circumitances, and mif-fuppofal with regard to the exiftence of circumftances which have not exifted; as alfo where the force, even of extraordinary punifhment, is rendered inoperative by the fuperior force of a phyfical danger or threatened mifchief. It is evident, that in thefe cafes, if the thunders of the law prove impotent, the whifpers of fimple morality can have but little infuence.

XII.

3. As to the cafes where puninment would be unprofitable. Thefe How far, are the cafes which confitute the great field for the exclufive inter- where it ference of private ethics. When a punißhment is unprofitable, or in profitable. other words too expenfive, it is becaufe the evil of the punifhment exceeds that of the offence. Now the evil of the punimment, we may remember*; is diftinguifhable into four branches: $r$. The evil of

- See ch, xiii. [Cafes unmeet.] $\$$ iv.

Vor. I. 
INTROD. coercion, including conftraint or reftraint, according as the act comCa. XVII. manded is of the pofitive kind or the negative. 2. The evil of apprehenfion. 3. The evil of fufferance. 4. The derivative evils refulting to perfons in connection with thofe by whom the three abovementioned original evils are fuftained. Now with refpect to thofe original evils, the perfons who lie expofed to them may be two very different fets of perfons. In the firft place, perfons who may have actually committed, or been prompted to commit, the acts really meant to be prohibited. In the next place, perfons who may have performed, or been prompted to perform, fuch other acts as they fear may be in danger of being involved in the punifhment defigned only for the former. But of thefe two fets of acts, it is the former only that are pernicious: it is, therefore, the former only that it can be the bufinefs of private ethics to endeavour to prevent. The latter being by the fuppofition not mifchievous, to prevent them is what it can no more be the bufinefs of ethics to endeavour at, than of legination. It remains to thew how it may happen, that there fhould be acts really pernicious, which, although they may very properly come under the cenfure of private ethics, may yet be no fit objects for the leginator to controul.

\section{XIII.}

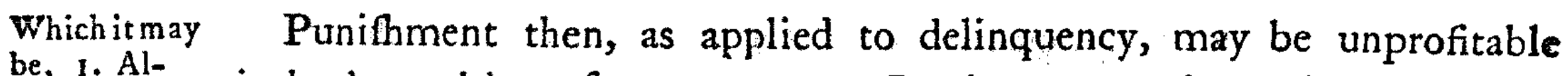
be, i. Alfined to the guilty. in both or either of two ways : I. By the expence it would amount to, even fuppofing the application of it to be confined altogether to delinquency: 2. By the danger there may be of its involving the innocent in the fate defigned only for the guilty. Firft then, with regard to the cafes in which the expence of the punifhment, as applied to the guilty, would outweigh the profit to be made by it. Thefe cafes, it is evident, depend upon a certain proportion between the evil of the punifhment and the evil of the offence. Now were the offence of fuch a nature, that a punifhment which, in point of magnitude, fhould but juft exceed the profit of it, would be fufficient to prevent it, it might be rather difficult perhaps to find an inftance in which fuch punifhment would clearly appear to be unprofitable. But the fact is, there are many cafes in which a punifhment, in order to have any chance of being 
being efficacious, muft, in point of magnitude, be raifed a great deal INTROD: above that level. Thus it is, wherever the danger of detection is, or, $\mathrm{C}_{\mathbf{H}}$. XVII. what comes to the fame thing, is likely to appear to be, fo fmall, as to make the punifhment appear in a high degree uncertain. In this cafe it is neceffary, as has been thewn*, if punifhment be at all applied, to raife it in point of magnitude as much as it falls fhort in point of certainty. It is evident, however, that all this can be but guefs-work: and that the effect of fuch a proportion will be rendered precarious, by a variety of circumftances: by the want of fufficient promulgation on the part of the law $t:$ by the particular circumftances of the temptation $\neq$ : and by the circumftances influencing the fenfibility of the feveral individuals who are expofed to it $\|$ Let the feducing motives be firong, the offence then will at any rate be frequently committed, Now and then indeed, owing to a coincidence of circumftances more or lefs extraordinary, it will be detected, and by that means puninhed. But for the purpofe of example, which is the principal one, an at of punifhment, confidered in itfelf, is of no ufe: what ufe it can be of, depends altogether upon the expectation it raifes of fimilar punifhment, in future cafes of fimilar delinquency. But this future punifhment, it is evident, muft always depend upon detection. If then the want of detection is fuch as muft in general (efpecially to eyes fafcinated by the force of the feducing motives) appear too improbable to be reckoned upon, the punifhment, though it hould be inllicted, may come to be of no ufe. Here then will be two oppofite evils running on at the fame time, yet neither of them reducing the quantum of the other : the evil of the difeafe, and the evil of the painful and inefficacious remedy. It feems to be partly owing to fome fuch confiderations, that fornication, for example, or the illicit commerce between the fexes, has commonly either gone altogether unpunifhed, or been punimed in a degree inferior to that in which, on other accounts, leginators might have been difpofed to punifh it.

- Ch. xiv. [Proportion] xviii. Rule 7. +Ch. xiii. [Cafes unmeet] \& iii. Append. tit. [Promulgation.] I Ch, xi. [Difpofition] xxxv. \&c. \| Ch. vi. [Senfibility.]

$\mathrm{Sr}_{2} \quad \mathrm{XIV}$. Secondly, 
INTROD.
XIV.

Secondly, with regard to the cafes in which political punifhment, as applied to delinquency, may be unprofitable, in virtue of the danger there may be of its involving the innocent in the fate defigned only for the guilty. Whence fhould this danger then arife? From the difficulty there may be of fixing the idea of the guilty action: that is, of fubjecting it to fuch a definition as hall be clear and precife enough to guard effectually againft mifapplication. This difficulty may arife from either of two fources: the one permanent, to wit, the nature of the actions themfelves: the other occafional, I mean the qualities of the men who may have to deal with thofe actions in the way of government. In as far as it arifes from the latter of thefe fources, it may depend partly upon the ufe which the legiflator may be able to make of language; partly upon the ufe which, according to the apprehenfion of the leginator, the judge may be difposed to make of it. As far as legiflation is concerned, it will depend upon the dégree of perfection to which the arts of language may have been carried, in the firft place, in the nation in general; in the next place, by the legilator in particular. It is to a fenfe of this difficulty, as it fhould feem, that we may attribute the caution with which moft legiflators have abftained from fubjecting to cenfure, on the part of the law, fuch actions as come under the notion of rudenefs, for example, or treachery, or ingratitude. The attempt to bring acts of fo vague and queftionable a nature under the controul of law, will argue either a very immature age, in which the difficulties, which give birth to that danger are not defcried; or a very enlightened age, in which they are overcome $c_{\text {. }}$

- In certain countries, in which the voice of the people has a more efpecial controul over the hand of the legifator, nothing can exceed the dread which they are under of ieeing any effectual provifion made againft the offences which come under the head of defamation, particularly that branch of it which may be tiled the political. This dread feems to depend partly upon the apprehenfion they may think it prudent to entertain of a defect in point of ability or integrity on the part of the leginator, partly upon a fimilar apprehenfion of a defect in point of integrity on the part of the judge.

$\mathrm{XV}$. For 
$\mathrm{XV}$.

INTROD.

For the fake of obtaining the clearer idea of the limits between the art of legination and private ethics; it may now be time to call to mind the diftinctions above eftablimed with regard to ethics in general. The degree in which private ethics ftands in need of the affiftance of legination, is different in the three branches of duty above diftin$\mathrm{C}_{\mathrm{H}}$. XVI. Legination how far neceffary for hed. Of the rules of moral duty, thofe which feem to ftand leaft prudense. in need of the affiftance of legination, are the rules of prudence. It can only be through fome defect on the part of the underftanding, if a man be ever deficient in point of duty to himfelf. If he does wrong, there is nothing elfe that it can be owing to but either fome inadvertence * or fome mif-suppofal *, with regard to the circumftances

on which his happinefs depends. It is a ftanding topic of complaint, that a man knows too little of himfelf. Be it fo: but is it fo certain that the leginator muft know more ${ }^{d}+$ ? It is plain, that of individuals the leginator can know nothing: concerning thofe points of conduct which depend upon the particular circumftances of each individual, it is plain, therefore, that he can determine nothing to advantage. It is only with refped to thofe broad lines of conduct in which all perfons, or very large and permanent defcriptions of perfons, may be in a way. to engage, that he can have any pretence for interfering; and even here the propriety of his interference will, in moft inftances, lie very open to difpute. At any rate, he muft never expect to produce a perfect compliance by the mere force of the fanction of which he is himfelf the author. All he can hope to do, is to encreafe the efficacy of private ethics, by giving ftrength and direction to the influence of the moral fanction. With what chance of fuccefs, for example, would

d. On occafions like this, the legiflator hould never bre fight of the well-known ftory of the oculift and the fot. A countryman who had hurt his eyes by drinking, went to a celebrated oculift for advice. He found him at table, with a glafs of wine before him. "You mutt leave of drinking," faid the oculift. "How fo;" fays the countryman? "You don't, andyet methinks your own eyes are none of the beft." "That's very true, friend," replied the oculift: "but you are to know, I love my " bottle better than my eyes."

- See ch.ix. [Confciouners.]

t Chi xvi. [Divifion] lii. 
INTROD. leginator go about to extirpate drunkennefs and fornication, by dint of CH. XVII. legal punifhment? Not all the tortures which ingenuity could invent would compars it: and, before he had made any progrefs worth regarding, fuch a mafs of evil would be produced by the punifhment, as would exceed, a thoufand-fold, the utmoft poffible mifchief of the offence. The great difficulty would be in the procuring evidence; an object which could not be attempted, with any probability of fuccefs, without fpreading difmay through every family ${ }^{\circ}$, tearing the bonds of fympathy afunder ${ }^{f}$, and rooting out the influence of all the focial motives. All that he can do then, againft offences of this nature, with any profpect of advantage, in the way of direct legination, is to fubject them, in cafes of notoriety, to a night cenfure, fo as thereby to cover them with a night thade of artificial difrepute:

\section{XVI.}

too far in $\mathrm{go}$ It may be obferved, that with regard to this branch of duty, legifthis refpect. lators have, in general, been difpofed to carry their interference full as far as is expedient. The great difficulty here is, to perfuade them to confine themfelves within bounds. A thoufand little paffions and prejudices have led them to narrow the liberty of the futoject in this the, in cafes in which the punithment is either attended with no profit at all, or with none that will make up for the expence.

\section{XVII.}

- Particularly in matters of re-

The mifchief of this fort of interference is more particularly conligion. fpicuous in the article of religion. The reafoning, in this cafe, is of the following ftamp. There are certain errons, in matters of belief, to which all mankind are prone: and for thefe errors in judgment, it is the determination of a Being of infinite benevolence, to punith them with an infinity of torments. But from thefe errors the leginator himfelf is neceffarily free: for the men, who happen to be at hand for him to confult with, being men perfectly enlightened, unfettered, and unbiaffed, have fuch advantages over all the reft of the world, that when they fit down to enquire out the truth relative to points fo plain and

- Evil of apprehenfion : third branch of the evil of a punifhment. Ch. xiii, $\$$ iv.

Derivative evils : fourth branch of the evil of a punifhment. Ib. 
fo familiar as thofe in queftion, they cannot fail to find it. This being INTROD. the cafe, when the fovereign fees his people ready to plunge headlong: CH. XVII. into an abyfs of fire, fhall he not ftretch out a hand to fave them? Such, for example, feems to have been the train of rearoning, and fuch the motives, which led Lewis the XIVth into thore coercive meafures which he took for the converfion of heretics, and the confirmation of true believers. The ground-work, pure fympathy and lovingkindnefs: the fuperftructure, all the miferies which the moft determined malevolence could have devifed ${ }^{\mathrm{B}}$. But of this more fully in another place *.

XVIII.

The rules of probity are thofe, which in point of expediency ftand - How far moft in need of affiftance on the part of the leginator, and in which, in neceffary for point of point of fact, his interference has been moft extenfive. There are few dictates of cafes in which it would be expedient to punith a man for hurting bimfelf: probity. but there are few cafes, if any, in which it would not be expedient to punifh a man for injuring his neighbour. With regard to that branch of probity which is oppofed to offences againit property, private ethics depends in a manner for its very exiftence upon legillation. Legination muft firft determine what things are to be regarded as each man's property, before the general rules of ethics, on this head, can have

B I do not mean but that other motives of a lefs focial nature might have introduced themfelves, and probably, in point of fact, did introduce themfelves, in the progrefs of the enterprize. But in point of poffibility, the motive above-mentioned, when accompanied with fuch a thread of reafoning, is fufficient, without any other, to account for all the effects above alluded to. If any others interfere, their interference, how natural foever, may be looked upon as an accidental and inefiential circumftance, not neceffary to the production of the efiect. Sympathy, a concern for the danger they appear to be expoled to, gives birth to the with of freeing them from it : that win hews itfelf in the hape of a command: this command produces difobedience: difobedience on the one part, produces difappointment on the other: the pain of difappointment produces ill-will towards thofe who are the authors of it. The affections will ofen make this progrefs in lefs time than it would take to defcribe it. The fentiment of wounded pride, and other modifications of the love of reputation and the love of power, add fowel to the flame. A kind of revenge exafperates the feverities of coercive policy.

- See B. I. tit. [Self-regarding offences.] 
INTROD. any particular application. The cafe is the fame with regard to ofC. XVII. fences againft the ftate. Without legination there would be no fuch thing as a ftate: no particular perfons invefted with powers to be exercifed for the benefit of the reft. It is plain, therefore, that in this branch the interference of the leginator cannot any where be difpenfed with. We muft firt know what are the dictates of legination, before we can know what are the dictates of private ethics ${ }^{\text {h }}$.

\section{XIX.}

As to the rules of beneficence, thefe, as far as concerns matters of dictates of detail, muft neceffarily be abandoned in great meafure to the jurifdiction of private ethics. In many cafes the beneficial quality of the act depends effentially upon the difpofition of the agent; that is, upon the motives by which he appears to have been prompted to perform it: upon their belonging to the head of fympathy, love of amity, or love of reputation; and not to any head of felf-regarding motives, brought into play by the force of political conftraint: in a word, upon their being fuch as denominate his conduct free and voluntary, according to one of the many fenfes given to thofe ambiguous expreffions: The limits of the law on this head feem, however, to be capable of being extended a good deal farther than they feem ever to have been extended hitherto. In particular, in cafes where the perfon is in danger, why

- But fuppofe the dietates of legination are not what they ought to be: what are then, or (what in this cafe comes to the fame thing) what ought to be, the dictates of private ethics? Do they coincide with the dietates of legifiation, of do they oppofe them, or do they remain neuter? a very interefting queftion this, but one that belongs not to the prefent fubject. It belongs exclufively to that of private ethics. Principles which may lead to the folution of it may be feen in A Fragment on Government, p. 150, Lond, 1776 .

IIf we may believe M. Voltaire $\bullet$, there was a time when the French ladies who thought themfelves neglected by their hufbands, ufed to petition pour âtre embefoignies : the technical word, which, he fays, was appropriated to this purpofe. Thefe fort of law-proceedings feem not very well calculated to anfwer the defign : accordingly we bear nothing of them now-a-days. The French ladies of the prefent age feem to be under no fuch dificulties.

Queft. fur l'Encyclop. tom. 7. art. Impuiffance. 
thould it not be made the duty of every man to fave another from mif"chief, when it can be done without prejudicing himfelf, as well as to abftain from bringing it on him? This accordingly is the idea purfued in the body of the work ${ }^{k}$.

\section{XX.}

To conclude this fection, let us recapitulate and bring to a point the difference between private ethics, confidered as an art or fcience, on the one hand, and that branch of jurifprudence which contains the art or fcience of legination, on the other. Private ethics teaches how each man may difpore himfelf to purfue the courfe moft conducive to his own happinefs, by means of fuch motives as offer of themfelves : the art of legillation (which may be confidered as one branch of the fcience of jurifprudence) teaches how a multitude of men, compofing a community, may be difpofed to purfue that courfe which upon the whole is the moft conducive to the happinefs of the whole community, by means of motives to be applied by the legiflator.

We come now to exhibit the limits between penal and civil jurifprudence. For this purpore it may be of ufe to give a diftinct though fummary view of the principal branches into which jurifprudence, confidered in its utmoft extent, is wont to be divided.

\section{\$2. Juripprudence, its branches.}

\section{XXI.}

Jurifprudence is a fictitious entity : nor can any meaning be found for the word, but by placing it in company with fome word that thall be fignificative of a real entity. To know what is meant by jurifpradence, we mult know, for example, what is meant by a book of jurifprudence. A bock of jurifprudence can have but one or the other of two

k A woman's head-drefs catches fire: water is at hand: a man, inftead of affiting to quench the fire, looks on, and laughs at it. A drunken man, falling with his face downwards into a puddle, is in danger of fuffocation: lifting his head a little on one fide would fave him: another man fees this and lets him lic. A quantity of gunpowder lies fcattered about a room: a man is going into it with a lighted candle: another, knowing this, lets him go in without warning. Who is there that ii any of the efe cafes would think punimment mifapplied?

VoL. I,

Difference between private ethics and the art of legiflation recapitulated.
Jurifpru dence, ex. pofitorycenforial.

VoL. I
$\mathrm{T} t$
objects : 
INTROD. objects: I. To afcertain what the law ${ }^{1}$ is: 2 . To afcertain what it ought $\mathrm{C}_{\mathrm{H}}$. XVII. to be. In the former cafe it may be ftiled a book of expofitory jurifprudence; in the latter, a book of cenforial jurifprudence : or, in other words, a book on the art of legilation.

XXII.

Expofitory A book of expofitory jurifprudence is either autboritative or unautbojurifpru- dence, autho- ritative. It is filed authoritative, when it is compofed by him who, by ritative-un- reprefenting the ftate of the law to be fo and fo, caufech it fo to be ; authoritative. that is, of the leginator himfelf : unauthoritative, when it is the work of any other perfon at large.

\section{XXIII.}

Sources of the difinc. tions yet remaining.

Now law, or the law, taken indefinitely, is an abtract and collective term; which, when it means any thing, can mean neither more nor lefs than the fum total of a number of individual laws taken together ${ }^{m}$. It follows, that of whatever other modifications the fubject of a book of jurifprudence is fufceptible, they muft all of them be taken from fome circumftance or other of which fuch individual laws, or the affemblages into which they may be forted, are fufceptible. The circumftances that have given rife to the principal branches of jurifprudence we are wont to hear of, feem to be as follow: I. The extent of the laws in queftion in point of dominion. 2. The political quality of the perfons whofe conduct they undertake to regulate. 3. The time

1 The word law itfelf, which ftands fo much in need of a definition, muft wait for it awhile, (fee $\$ 3$ ): for there is no doing every thing at once. In the mean time every reader will underftand it according to the notion he has been accuftomed to annex to it.

In moft of the European languages there are two different words for diftinguining the abftract and the concrete fenfes of the word law: which words are fo wide afunder as not evert to have any etymological affinity. In Latin, for example, there is lex for the concrete fenfe, $j u s$ for the abftract: in Italian, legge and diritto: in French, loi and droit: in Spanifh, ley and derecho: in German, gefetz and recht. The Englifh is at prefent deftitute of this advantage.

In the Anglo-Saxon, befides lage, and feveral other words, for the concrete fenfe, there was the word right, anfwering to the German recht, for the abftract; as may be feen in the compound folc-right, and in other inftances. But the word right having long ago. loft this fenfe, the modern Englinh no longer poffeffes this advantage. 


\section{Of the [L I M I T S] of the penal branch of juripprudence.}

of their being in force. 4. The manner in which they are expreffed. INTROD. 5. The concern which they have with the article of punisment.

In the firf place, in point of extent, what is delivered concerning the laws in queftion, may have reference either to the laws of fuch or fuch a nation or nations in particular, or to the laws of all nations whatfoever: in the firt cafe, the book may be faid to relate to local, in the other, to univerfal, juripprudence.

Now of the infinite variety of nations there are upon the earth, there are no two which agree exactly in their laws : certainly not in the whole; perhaps not even in any fingle article : and let them agree to-day, they would difagree to-morrow. This is evident enough with regard to the fubftance of the laws: and it would be ftill more extraordinary if they agreed in point of form; that is, if they were conceived in precifely the fame ftrings of words. What is more, as the languages of nations are commonly different, as well as their laws, it is feldom that, ftrictly fpeaking, they have fo much as a fingle word in common. However, among the words that are appropriated to the fubject of law, there are fome that in all languages are pretty exactly correfpondent to one another: which comes to the fame thing nearly as if they were the fame. Of this ftamp, for example, are thofe which correfpond to the words power, right, obligation, liberty, and many others.

It follows, that if there are any books which can, properly fpeaking, be ftiled books of univerfal jurifprudence, they muft be looked for within very narrow limits. Among fuch as are expofitory, there can be none that are authoritative: nor even, as far as the fubfance of the laws is concerned, any that are unauthoritative. To be fufceptible of an univerfal application, all that a book of the expofitory kind can have to treat of, is the import of words : to be, Atrictly fpeaking, univerfal, it muft confine itfelf to terminology. Accordingly the definitions which there has been occafion here and there to interfperfe in the courfe of the prefent work, and particularly the definition hereafter given of the word law, may be confidered as matter belonging to the head of univerfal jurifprudence. Thus far in ftrictnefs of fpeech: though in point of ufage, where a man, in laying down what he apprehends to be 
INTROD. the law, extends his views to a few of the nations with which his own is Cr. XVII. moft connected, it is common enough to confider what he writes as relating to univerfal jurifprudence.

It is in the cenforial line that there is the greateft room for difquifitions that apply to the circumftances of all nations alike: and in this line what regards the fubftance of the laws in queftion is as fufceptible of an univerfal application, as what regards the words. That the laws of all nations, or even of any two nations, Mould coincide in all points, would be as ineligible as it is impoffible : fome leading points, however, there feem to be, in refpect of which the laws of all civilized nations might, without inconvenience, be the fame. To mark out fome of thefe points will, as far as it goes, be the bufinefs of the body of this work.

\section{$\mathrm{XXV}$.}

-internal and international.
In the fecond place, with regard to the political quality of the perfons whofe conduct is the object of the law. Thefe may, on any given occafion, be confidered either as members of the fame ftate, or as members of different ftates: in the firft cafe, the law may be referred to the head of internal, in the fecond cafe to that of international? jurifprudence.

Now as to any tranfactions which may take place between individuals who are fubjects of different ftates, thefe are regulated by the internal laws, and decided upon by the internal tribunals, of the one or the other of thofe ftates : the cafe is the fame where the fovereign of the one has any immediate tranfactions with a private member of the other: the fovereign reducing himfelf, pro re nat $a$, to the condition of a private perfon, as often as he fubmits his caufe to either tribunal;

"The word international, it muft be acknowledged, is a new one; though, it is hoped, fufficiently analogous and intelligible. It is calculated to exprefs, in a more fignificant way, the branch of law which goes commonly under the name of the law of nations: an appellation fo uncharacterific, that, were it not for the force of cuftom, it would feem rather to refer to internal jurifprudence. The chancellor D'Agueffeau has already made, I find, a fimilar remark: he fays, that what is commonly called droit des gens, ought rather to be termed droit entre les gens*.

* Oeuvres, Tom, II. p. 337 , Edit. $1773,12 \mathrm{mc}$

whether 
whether by claiming a benefit, or defending himfelf againft a burthen. INTROD. There remain then the mutual tranfactions between fovereigns, as fuch, $\mathrm{C}_{\mathrm{H}}$. XVII. for the fubject of that branch of jurifprudence which may be properly and exclufively termed international.

With what degree of propriety rules for the conduct of perfons of this defcription can come under the appellation of laws, is a queftion that muft reft till the nature of the thing called a law fhall have been more particularly unfolded.

It is evident enough, that international jurifprudence may, as well as internal, be cenforial as well as expofitory, unauthoritative as well as authoritative.

\section{XXVI.}

Internal jurifprudence, again, may either concern all the members of Internal jua ftate indifcriminately, or fuch of them only as are connected in the way of refidence, or otherwife, with a particular diftrict. Jurifprudence is accordingly fometimes diftinguifhed into national and provincial. But as the epithet provincial is hardly applicable to diftricts fo fmall as many of thofe which have laws of their own are wont to be, fuch as towns, parifhes, and manors; the term local (where univerfal jurifprudence is plainly out of the queftion) or the term particular, though

- In the times of James I. of England, and Philip III. of Spain, certain merchants at London happened to have a claim upon Philip, which his ambaffador Gondemar did not think fit to fatisfy. They applied for counfel to Selden, who advifed them to fue the Spanim monarch in the court of King's Bench, and profecute him to an out. lawry. They did fo: and the theriffs of London were accordingly commanded, in the ufual form, to take the body of the defendant Philip, wherever it was to be found within their bailywick. As to the fheriffs, Philip, we may believe, was in no great fear of them: but, what anfwered the fame purpofe; he happened on his part to have demands upon fome other merchants, whom, fo long as the outlawry remained in force, there was no proceeding againf. Gondemar paid the money*. This was internal jurifprudence: if the difpute had been betwixt Philip and James himfelf, it would have been international.

* Selden's Table-Talk, tit. LAw.

rifprudence, national and provincial, local or par. ticular. 
INTROD. this latter is not very characteriftic, might either of them be more CH. XVII. commodious ${ }^{p}$.

\section{XXVII.}

Jurifpru- Thirdly, with refpect to time. In a work of the expofitory kind, dence, an- the laws that are in queftion may either be fuch as are ftill in force at ing. the time when the book is writing, or fuch as have ceafed to be in force. In the latter cafe the fubject of it might be termed antient; in the former, prefent or living jurifprudence: that is, if the fubftantive jurifprudence, and no other, muft at any rate be employed, and that with an epithet in both cafes. But the truth is, that a book of the former kind is rather a book of hiftory than a book of jurifprudence; and, if the word juripprudence be expreffive of the fubject, it is only with fome fuch words as biffory or antiquities prefixed. And as the laws which are any where in quertion are fuppofed, if nothing appears to the contrary, to be thofe which are in force, no fuch epithet as that of prefent or living commonly appears.

Where a book is fo circumftanced, that the laws which form the fubject of it, though in force at the time of its being written, are in force no longer, that book is neither a book of living jurifprudence, nor a book on the hiftory of jurifprudence : it is no longer the former, and it never was the latter. It is evident that, owing to the changes which from time to time muft take place, in a greater or lefs degree, in every body of laws, every book of jurifprudence, which is of an expofitory hature, muft, in the courfe of a few years, come to partake more or lefs of this condition.

The moft common and moft ufeful object of a hiftory of jurifprudence, is to exhibit the circumftances that have attended the eftablimment of laws actually in force. But the expofition of the dead laws which have been fuperfeded, is infeparably interwoven with that of the living ones which have fuperfeded them. The great ufe of both thefe

p The term municipal feemed to anfwer the purpofe very well, till it was taken by an Englith author of the firft eminence, to fignify internal law in general, in contradiftinction to international law, and the imaginary law of nature. It might ftill be afed in this fenfe, without fcruple, in any other language. 
branches of fcience, is to furnilh examples for the art of legiflation?.

\section{XXVIII.}

Fourthly, in point of exprefion, the laws in quettion may fubfift either in the form of fatute or in that of cuftomary law. As to the difference between thefe two branches (which refpects only the article of form or expreffion) it cannot properly be made appear till fome progrefs has been made in the definition of $a$ law.

\section{XXIX.}

Laftly, The moft intricate diftinction of all, and that which comes moft frequently on the carpet, is that which is made between the civil branch of jurifprudence and the penal, which latter is wont, in certain circumftances, to receive the name of criminal.

What is a penal code of laws? What a civil code? Of what nature are their contents? Is it that there are two forts of laws, the one penal the other civil; fo that the laws in a penal code are all penal laws, while the laws in a civil code are all civil laws? Or is it, that in every law there is fome matter which is of a penal nature, and which thereJurifprudence, ftatutory - cufto mary. fore belongs to the penal code; and at the fame time other matter which is of a civil nature, and which therefore belongs to the civil code? Or is it, that fome laws belong to one code or the other exclufively, while others are divided between the two? To anfwer thefe queftions in any manner that thall be tolerably fatisfactory, it will be neceffary to afcertain what a law is: meaning one entire but fingle

q Of what ftamp are the works of Grotius, Puffendorf, and Burlamaqui? Are they political or ethical, hiftorical or juridical, expofitory or cenforial :-Sometimes one thing, fometimes another: they feem hardly to have fettled the matter with themfelves. A defect this to which all books muft almoft unavoidably be liable, which take for their fubject the pretended law of nature: an obfcure phantom, which, in the imaginations of thofe who go in chace of it, points fometimes to manners, fometimes to laws; fometimes to what law is, fometimes to what it ought to be *. Montefquieu fets out upon the cenforial plan: but long before the conclufion, as if he had forgot his firt defign, he throws off the cenfor, and puts on the antiquarian. The Marquis Beccaria's book, the firt of any account that is uniformly cenforial, concludes, as it fets out, with penal jurifprudence.

* See Chap, II. [Principles adverfe] xiv.

Jurifprudence, civil -penalcriminal.

Queftion, concerning. the diftinction between the civil brancly and the penal, ftated. 
INTROD. law: and what are the parts into which a law, as fuch, is capable of

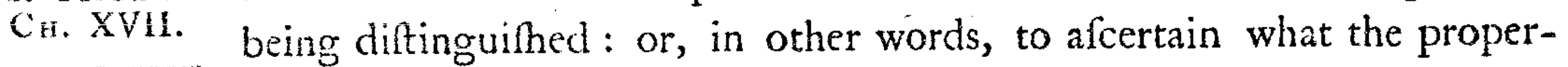
ties are that are to be found in every object which can with propriety receive the appellation of $a$ law. This then will be the bufinefs of the third and fourth fections : what concerns the import of the word criminal, as applied to law, will be difcuffed feparately in the fifth ?.

Occaín and purpole of this concluding anue.

By a $l .2 w$ lrere is not meant a fuitute.

Every law is either a comvocation of one. A declaratory law is not, properly fneaking, a law. r Here ends the original work, in the ftate into which it was brought in November, 1780. What follows is now added in January, 1789 .

The third, fourth, and fifth fections intended, as expreffed in the text, to have been added to this chapter, will not here, nor now be given : becaufe to give them in a manner tolerably compleat and fatisfactory, might require a confiderable volume. This volume will form a work of itfelf, clofing the feries of works mentioned in the preface.

What follows here may ferve to give a night intimation of the nature of the tak, which fuch a work will have to atchieve: it will at the fame time furnifh, not any thing like a fatisfactory anfwer to the queftions mentioned in the text, but a night and general indication of the courfe to be taken for giving them fuch an anfwer.

What is a law? What the parts of a law? The fubject of thefe queftions, it is to be obferved, is the logical, the ideal, the intellectual whole, not the plyyscal one.: the latw and not the fatule. An inquiry, directed to the latter fort of objest, could neither admit of difficulty nor afford intruction. In this fenfe whatever is given for law by the perfon or perfons recognized as poffeffing the power of making laws, is law. The Metamorphofes of Ovid, if thus given, would be law. So minch as was embraced by one and the fame at of authentication, fo much as received the touch of the fceptre at one Atroke, is one law: a whole law, and nothing more. A ftatute of George II. made to fubftitute an or infted of an and in a former ftatute is a compleat law: a ftatute containing an entire body of laws, perfect in all its parts, would not be more fo. By the word law then, as often as it occurs in the fucceeding pages, is meant that ideal object, of which the part, the whole, or the multiple, or an affemblage of parts, wholes, and multiples mixed together, is exhilited by a ftatute; not the ftatute which exhibits them.

Every law, when compleat, is either of a coercive or an uncoercive nature.

A coercive law is a command.

An uncoercive, or rather a di/coercive, law is the rerocation, in whole or in part, of a coercive law.

What has been termed a declaratory law, fo far as it ftands diftinguifhed from either a coercive or a difcoercive law, is not properly fpeaking a law. It is not the exprcfion of an ant of the will exercifed at the time $:$ it is a mere notification of the exiftence of a law, either of the coercive or the difcoercive kind, as already fubfinting: of the exiftence of fome document expreffive of fome act of the will, exercifed, not at the tims, but at fome former period. If it does any thing more than give information of this fikt, viz. of the prior exiftence of a law of either the coercive or the difcoercive kind, it ceafes pro 


\section{Of the [L I M IT S] of the penal branch of juriprudence.}

tanto to be what is meant by a declaratory law, and affuming either the coercive or the difcoercive quality.

Every coercive law creates an offence, that is, converts an act of fome fort or other into an offence. It is only by fo doing that it can impofe obligation, that it can produce coercion.

A law confining itfelf to the creation of an offence, and a law commanding a puninment to be adminiftered in cafe of the commiffion of fuch an offence, are two diftinct laws; not parts (as they feem to have been generally accounted hitherto) of one and the fame law. The acts they command are altogether different; the perfons they are addreffed to are altogether different. Inftance, Let no man fteal; and, Let the judge caufe whoever is convicted of fealing to be banged.

They might be ftiled; the former, a fimply imperative law; the other, a punitory: but the punitory, if it commands the punifhment to be inflicted, and does not merely permit it, is as truly imperative as the other: only it is punitory befides, whichthe other is not.

A law of the difcoercive kind, confidered in itfelf, can have no punitory law belonging to it : to receive the affiftance and fupport of a punitory law, it muft firft receive that of a fimply imperative or coercive law, and it is to this latter that the punitory law will attach itfelf, and not to the difcoercive one. Example; 'difcoercive law. The periff bas powter to bang all fuch as 'the judge, proceeding in due courfe of law, Shall order bim to bang. Example of a coercive law, made in fupport of the above difcoercive one. Let no man binder the Beriff from banging fach as the judge, proceeding in due courfe of larw, Ball order bim to bang. Example of a punitory law, made in fupport of the above coercive one. Let the judge caufe to be imprifoned whofoever attempts to binder the Beriff from banging one, whom the judge, proceeding in due courfe of law, bas ordered bim to bang.

But though a fimply imperative law, and the punitory law attached to it, are fofar diftinct laws, that the former contains nothing of the latter, and the latter, in its dires tenor, contains nothing of the former; yet by implication, and that a neceffury one, the punitory does involve and include the import of the fimply imperative law to which it is appended. To fay to the judge, Caufe to be banged rwberver in due form of larw is con vized of fealing, is, though not a direct, yet as intelligible a way of intimating to men in general that they muft not fteal, as to fay to them directly, Do not feal : and one fees, how much more likely to be efficacious.

It fhould feem then, that, wherever a fimply imperative law is to have a punitory one appended to it, the former might be fpared altogether : in which cafe, faving the exception, (which naturally thould feem not likely to be a frequent one) of a law capable of anfwering its purpofe without fuch an appendage, there thould be no occafion in the whole body of the law for any 'other than punitory, or in other words than penal, laws. And this, perhaps, would be the cafe, were it not for the neceffity of a large quantity of matter of the expofitory kind, of which we come now to fpeak.

It will happen in the inftance of many, probably of moft, poffibly of all commands endued with the force of a public law, that, in the expreftion given to fuch a command,

Vou. I. 
it thall be neceffary to have recourfe to terms too complex in their fignification to exhibit the requifite ideas, without the affiftance of a greater or lefs quantity of matter of an expofitory nature. Such terms, like the fymbols ufed in algebraical notation, are rather fubttitutes and indexes to the terms capable of themfelves of exhibiting the ideas in queftion, than the real and immediate reprefentatives of thofe ideas.

Take for inftance the law, Thou falt not freal: Such a command, were it to reft there, could never fufficiently anfwer the purpofe of a law. A word of fo vague and unexplicit a meaning can no otherwife perform this office, than by giving a general intimation of a variety of propofitions, each requiring, to convey it to the apprehenfion, a more particular and ample affemblage of terms: Stealing, for example, (according to a definition not accurate enough for ufe, but fufficiently fo for the prefent purpofe) is the taking of a thing cubich is another's, by one.wbo bas no TuTLE fo to do, and is confcious of bis baving noxe. Even after this expofition, fuppofing it a correct one, can the law be regarded as compleatly expreffed? Certainly not. For what is meant by a man"s baving a T x $\mathrm{T}$ L E to take a tbing? To be compleat, the law mutt have exhibited, amongit a multitude of other things, two catalogues: the one of events to which it has given the quality of conferring title in fuch a cafe; the other of the events to which it has given the quality of taking it arway. What follows? That for a man to have folen, for a man to barue bad no title to what be took, either no one of the articles contained in the firft of thofe lifts mult have happened in his favour, or if there has, fome one of the number of thofe contained in the fecond, mult have happened to his prejudice.

$X \mathrm{x}$.

Such then is the nature of a general law, that while the imperative part of it, the punctum faliens as it may be termed, of this artificial body, fhall not take up above two or three words, its expofitory appendage, without which that imperative part could not. rightly perform its office, may occupy a confiderable volume.

But this may equally be the care with a private order given in a family. Take for inAance one from a bookfeller to his foreman. Remove, from this Bop to my new one, my wbole frock, according to this printed catalogue.-Remorve, from this ßop to my new one, my wobole fock, is the imperative matter of this order: the catalogue referred to contains the expofitory appendage.

$X I T$. The fame mafs of expofitory matcer may ferve in common for many lawe.

XIIT. The imperative character effential to law, is apt to be consc.lled in and by expotitory
The fame mals of expofitory matter may ferve in common for, may appertain in common to, many commands, many maffes of imperative matter. Thus, amongft other things, the catalogue of collative and ablative events, with refpect to titles above fpoken of, (fee $\mathrm{N}^{\circ}$ IX. of thia note, aud fee the theet of corrections, laft paragraph but one, will belong in common to all or moft of the laws conftitutive of the various offences againft property. Thus, in mathematical diagrams, one and the fame bafe fhall ferve for a whole clufter of triangles.

Such expofitory matter, being of a complexion fo different from the imperative, it would be no wonder if the conneetion of the former with the latter fhould efcape the obfervation : which, indeed, is perhaps pretty generally the cafe. And folong as any mafs of legillative matter prefents itfelf, which is not itfelf imperative or the contrary, of of which the connection with matter of one of thofe two defcriptions is not apprehended, fo 


\section{Of the [L I M I T S] of the penal branch of juriprudenct.}

$\operatorname{cccuxxi}$

long and fo far the truth of the propofition, That ervery law is a command or its oppofite, CoNCLUD. may remain unfufpected, or appear queftionable; fo long alfo may the incompleatnefs of the greater part of thofe maffes of legiflative matter, which wear the complexion of compleat laws upon the face of them, alfo the method'to be taken for rendering them really compleat, remain undifcovered.

A circumftance, that will naturally contribute to increafe the difficulty of the difcovery, is the great variety of ways in which the imperation of a law may be conveyed - the great variety of forms which the imperative part of a law may indifcriminately affume : fome more directly, fome less directly expreffive of the imperative quality. Thou fbalt not fleal. Let no man fleal. Whofo fealeth Ball be punified fo and fo. If any man feal, be foall be punifed fo and fo. Stealing is wbere a man does fo and fo: the punifoment for ftealing is fo and fo. To judges, fo and fo named, and fo and fo conftituted, belong the cognizance of fuch and fuch offences; viz. fealing - and fo on. Thefe are but part of a multitude of forms of words, in any of which the command, by which ftealing is prohibited, might equally be couched: and it is manifeft to what a degree, in fome of them, the imperative quality is clouded and concealed from ordinary apprehenfion.

After this explanation, a general propofition or two, that may be laid down, may help to afford fome little infight into the fructure and contents of a compleat body of laws.-So many different forts of offences created, so many different laws of the coercive kind: fo many exceptions taken out of the defcriptions of thofe offences, fo many laws of the difcoercive kind.

To clars offences, as hath been attempted to be done in the preceding chapter, is therefore to clafs laws: to exhibit a compleat catalogue of all the offences created by law, including the whole mars of expofitory marter neceffary for fixing and exhibiting the import of the terms contained in the feveral laws, by which thofe offences are refpectively created, would be to exhibit a compleat colledtion of the laws in force: in a word, a compleat body of law, a pannomion, if fo it might be termed.

From the obfcurity in which the limits of a law, and the diftinction betwixt a law of the civil or fimply imperative kind and a punitory law, are naturally involved, refults the obfcurity of the limits betwixt a civil and a penal code, betwixt the civil branch of the law and the penal.

The queftion, What parts of the total mafs of legiflative matter belong to the civil branch, and what to the penal? fuppofes that divers political ftates, or at leaft that fome one fuch ftate, are to be found, having as well a civil code as a penal code, each of them compleat in its kind, and marked out by certain limits. But no one fuch ftate has ever yet exifted.

To put a queftion to which a true anfwer can be given, we muft fubftitute to the fore.. going queftion fonie fuch one as that which follows:

Suppofe two mafies of legiflative matter to be drawn up at this time of day, the one under the name of a civil code, the other of a penal code, each meant to be compleat in its kind-in what general way, is it natural to fuppofe, that the different forts of matter, as above difting athed, would be diftributed between them ?

XIV. The concea! ment is favour ed by the mu:titude of indirect forms in which imperative matter is capabie of be. ing couched.

$x v$. Number and nature of the law's in a corle, ed.

$x \vee 1$. General iver of the liniture tween a cir and a pera code. 
$\operatorname{eccxxxii}$

CONCLUD. ING NOTE.

XVII.

Contents of civil cole.

XVIII, Contents of penal code.

XIX: In the Code Frederic the imperative character is al muft loft in the expofitory matter.

$\mathrm{XX}$. So in the Roman law.

$\mathrm{XXI}$. In the harba rian codes it Atands confpi chous.

XXIr Esnftitutional eude, its connexion with the two others

\section{Of the [L I M I T S] of the penal branch of juripprudence:}

To this queftion the following anfwer feems likely to come as near as any other to the truth.

The civil code would not conffit of a collection of civil laws, each compleat in itfelf, as well as clear of all penal ones:

Neither would the penal code (fince we have feen that it could not) confift of a collection of punitive laws, each, not only compleat in itfelf, but clear of all civil ones. But

The civil code would confift chiefiy of mere maffes of expofitory matter. The imperative matter, to which thofe mafes of expofitory matter refpectively appertained, would be found-not in that fame code-not in the civil code-nor in a pure ftate, free from all admixture of punitory laws; but in the penal code-in a ftate of combination-involved, in manner as above explained, in fo many correfpondent punitory laws.

The penal code then would conffit principally of punitive laws, involving the imperative matter of the whole number of civil laws : along with which would probably alfo be found various maffes of expofitory matter, appertaining, not to the civil, but to the. punitory laws. The body of penal law, enacted by the Emprefs-Queen Maria Therefa, agrees pretty well with this account.

The mals of legiflative matter publifhed in French as well as German, under the aufpices of Frederic the IId. of Prufia, by the name of Code Frederic, but never efta. blithed with force of law *, appears, for example, to be almoft wholly compofed of maffes of expofitory matter, the relation of which to any imperative matter appears to have been. but very imperfectly apprehended:

In that enormous mafs of confufion and inconfiftency, the antient Roman, or, $2 s$ it is termed by way of eminence, the civil law, the imperative matter, and even all traces of the imperative character, feem at laft to have been fmothered in the expofitory. Efo had been the language of primeval fimplicity: efto had been the language of the twelve tables. By the time of Juftinian (fo thick was the darknefs raifed by clouds of commentators) the penal law had been crammed into an odd corner of the civil-the whole catar logue of offences, and even of crimes, lay buried under a heap of obligations-rwill whs hid in opinion-and the original efto had transformed itfelf into videtur, in the mouths even of the moft defpotic fovereigns.

Among the barbarous nations that grew up out of the ruins of the Roman Empire, Law, emerging from under the mountain of expofitory rubbifh, reafumed for a while the language of command: and then the had fimplicity at leaft, if nothing elfe, to recommend her.

Befides the civil and the penal, every compleat body of law mut contain a third branch, the confitutional.

The conftitutional branch is chiefly employed in conferring, on particular claffes of perfons, pazvers, to be exercifed for the good of the whole fociety, or of confiderable parts of it, and prefcribing duties to the perfons invefted with thofe powers.

The powers are principally conftituted, in the firft infance, by difcoercive or permifive laws, operating as exceptions to.certain laws of the coercive or imperativekind. Inftance:

Misabeau fur la Monarchio Pruffienne, Tom. v. Liv. 8. p. 2 I5. 


\section{of the [L I M I T S] of the penal branch of juripprudence.}

A tax-gatberer, as fuch, may, on fuch and fuch an ocsafion, take fuch and fuch things, witbout any otber TITLE.

The duties are created by imperative laws, addreffed to the perfons on whom the powers are conferred. Inftance : On fucb and fucb an occafion, fucb and fucb a tax-gatberer fall take fucb and fucb things. Such and fucb a judge foll, in fucb and fuch a cafe, caufe perfons fo and fo offending to be banged.

The parts which perform the function of indicating who the individuals are, who, in every cafe, thall be confidered as belonging to thofe claffes, have neither a permifive complexion, nor an imperative.

They are fo many mafles of expofitory matter, appertaining in common to all laws; into the texture of which, the names of thofe claffes of perfons have occafion to be inferted. Inftance : imperative matter:-Let the judge caufe wboever, in due courfe of law, is conruisted of ftealing, to be banged. Nature of the expofitory matter :-Who is the perfon meant by the word judge? He who has been invefted with that office in fuch a manner: and in refpect of whom no event has happened, of the number of thofe, to which the effect is given, of reducing him to the condition of one divefted of that office.

Thus it is, that one and the fame law, one and the fame command, will have its matter divided, not only between two great codes or main branches of the whole body of the laws; the civil and the penal; but amongt three fuch branches, the civil, the penal, and the conftitutional.

In countries, where a great part of the law exifts in no other thape, than that of what in England is called common law, but might be more expreffively termed judiciary, there mult be a great multitude of laws, the import of which cannot be fufficiently made out for practice, without referring to this common law, for more or lefs of the expofitory matter belonging to them. Thus in England the expofition of the word title, that bafis of the whole fabrick of the laws of property, is no where elfe to be found. And, as uncertainty is of the very effence of every particle of law fo denominated (for the inftant it is cloathed in a certain authoritative form of words it changes its nature, and paffes over to the other denomination) hence it is that a great part of the laws in being in fuch countries remain uncertain and incompleat. What are thofe countries? To this hour, every one on the furface of the globe:

Had the fcience of architecture no fixed nomenclature belonging to it-were there no fettled names for diftinguining the different forts of buildings, nor the different parts of the famebuilding from each other - what would it be ? It would be what the fcience of legiflation, confidered with refpect to its form, remains at prefent.

Were there no architects who could diftinguifh a dwelling-houfe from a barn, or a. fide-wall from a cieling, what would architects be?. They would be what all legiflators are at prefent.

From this very light and imperfect Retch, may be collected not an anfwer to the queftions in the text but an intimation, and that but an imperfect one, of the courfe to be taken for giving fuch an anfwer; and, at any rate, fome idea of the difficulty, as well zs of the neceffity, of the tak. codes.

XXIV. Expofitory matter à great quantity of it quantity of it exilts every where, in no other form than hat of common or judiciary law.

$\mathrm{XXV}$. Hence the de-
plorable ftate piorable ftate of the fcience of legination, confidered in reppect of its
form.

XXVI. Occafions affording an exemplification of the diniculty as well as importance of this. 


\section{ecexxxiv}

CONCLUD ING NOTE.

branch of

reience; - at

tempts tolinit

the powers of

hipreme repre

lentative

XXVIT.

Example:

Ametican de-

clarations of

righis

\section{Of the [L I M I T S] of the penal branch of juriprudence.}

If it were thought neceffary to recur to experience for proofs of this difficulty and this necelfity, they need not be long wanting.

Take, for inftance, fo many well-meant endeavours on the part of popular bodies, and fo many well-meant recommendations in ingenious books, to reftrain fupreme reprefentative affemblies from making laws in fuch and fuch cafes, or to fuch and fuch an effeck. Such laws, to anfwer the intended purpofe, require a perfect maftery in the fcience of law confidered in refpect of its form-in the fort of anatomy fpoken of in the preface to this work : but a perfeet, or even a moderate infight into that fcience, would prevent their being couched in thofe loofe and inadequate terms, in which they may be obferved fo frequently to be conceived; as a perfeet acquaintance with the diktates of utility on that head would, in many, if not in moft, of thofe inftances, difcounfel the attempt. Keep to the letter, and in attempting to prevent the making of bad laws, you will find them prohibiting the making of the moft neceffary laws, perhaps cven of all laws: quit the letter, and they exprefs no more than if each man were to fay, Your laws Ball become ipfo facio rooid, as oftin as they contain any thing which is not to my mind.

Of fuch unhappy attempts examples may be met with in the legiflation of many nations: but in none more frequently than in that newly-created nation, one of the moft enlightened, if not the moft enlightened, at this day on the globe.

Take, for inftance, the Declaration of Rigbts, enacted by the ftate of North-Carolina in convention, in or about the month of September, 1788, and faid to be copied, with 2 fmall exception, from one in like manner enacted by the ftate of Virginia*.

The following, to go no farther, is the firf and fundamental article :

" That there are certain natural rights, of which men, when they form a focial com" pact, cannot deprive or diveft their pofterity, among which are the enjoyment of life " and liberty, with the means of acquiring, poffeffing, and protecting property, and " purfuing and obtaining happinefs and fafety."

Not to dwell on the overfight of confining to pofterity the benefit of the rights thus de. clared, what follows? That-as againft thofe whom the protection, thus meant to be afforded, includes-every law, or other order, diveffing a man of the enjoyment of life or liberty, is void.

Therefore this is the cafe, amongt others, with every coercive law.

Therefore, as againft the perfons thus protected, every order, for example, to pay money on the fcore of taxation, or of debt from individual to individual, or otherwife, is void: for the effect of it, if complied with, is " to deprive and diveft bim," pro tanto, of the enjoyment of liberty, viz. the liberty of paying or not paying as he thinks proper: not to mention the fpecies oppofed to imprifonment, in the event of fach a mode of coercion's being reforted to : likewife of property, which is itfelf a " means of acquiring, pof. " feffing, and proteding property, and of purfuing and obtaining bappinefs and fafety."

Therefore alfo, as againt fuch perfons, every order to attack an armed encmy, in time of war, is alfo void: for, the neceffary effect of fuch an order is, "to deprive fome " of them of the enjoyment of life."

* Recherches fur les Etats-Unis, 8vo, 1788, Vol. I, p. 158 . 
The above-mentioned confequences may fuffice for examples, amongt an endlefs train of fimilar ones

Leaning on hïs elbow, in an attitude of profound and folemn meditation, "What a "multitude of things there are," (exclaimed the dancing-mafter Marcel,) " in a minuet!" -May we now add?-and in a law.

* The Virginian Declaration of Rights, faid, in the French work above quoted, to have been enacted the Ift of June, 1776 , is not inferted in the publication entitled "The Confitutions of the ferveral independent ftates of America, Ec." Publibed by order of Congrefs: Pbiladelpbia printed. Re-printed for Stockdele and Wal. ker, London, 1782 : though that publication contains the form of government enacted in the fame convention, between the 6th of May and the $5^{\text {th }}$ of July in the fame year.

But in that fame publication is contained a Declaration of Rigbts, of the province of Mafacbufots, dated in the years 1779 and 1780 , which in its firft article is a little fimilar: alfo one of the province of $P_{t n n}[y]-$ vania, dated between July $x_{5}$ th and September 28 th, in which the fimilarity is rather more confiderable.

Moreover, the famous Declaration of Independence, publifhed by Congrefs July tht 1776, after a preambular opening, goes on in thefe words: "We bold tbefo trutbs to befelf-evident: that all men are created equal: that they are endued by the creator with certain unatienalite rigbts: that among $f$ thofe are life, liberty, and the pursuit of bappiness.".

The Virginian Decläration of Rights is that, it feems, which claims the honour of having ferved as a model to thofe of the olher Provinces; and in refpect of the above leading article, at leaft, to the abovementioned general Declaration of Independency. See Recherches, \&c. I. 197.

Who can help lamenting, that fo rational a caufe fhould be refted upon reafons, fo much fitter to beget objections, than to remove them?

But with men who are unanimous and hearty about meafures, nothing fo weak but may pafs in the character of a reafon: nor is this the firft inftance in the world, where the conclufion has fupported the premifes, inftead of the premires the conclufion.

Ind of the Concluding Note and of the Work. 